Universidade de Brasília

Instituto de Letras - IL

Departamento de Teoria Literária e Literaturas - TEL

Programa de Pós-Graduação em Literatura - Doutorado

Área de concentração: Literatura e Práticas Sociais

Tese de Doutorado

\title{
A CIDADE TODA EM CONTRAMÃO: UMA LEITURA DA HIPERMODERNIDADE NAS CANÇÕES \\ CONTEMPORÂNEAS DE CHICO
}

\author{
Brunna Guedes Marques de Lima
}

Orientadora: Prof ${ }^{\mathrm{a}}$. Dra ${ }^{\mathrm{a}}$. Sylvia Helena Cyntrão 


\author{
Universidade de Brasília \\ Instituto de Letras \\ Departamento de Teoria Literária e Literaturas \\ Doutorado em Literatura
}

\title{
A CIDADE TODA EM CONTRAMÃO: UMA LEITURA DA HIPERMODERNIDADE NAS CANÇÕES CONTEMPORÂNEAS DE CHICO
}

\section{Brunna Guedes Marques de Lima Mat. 11/0076648}

\begin{abstract}
Tese de Doutorado em Literatura e Práticas Sociais, apresentada ao Programa de Pós-Graduação em Literatura do Departamento de Teoria Literária e Literaturas, do Instituto de Letras, da Universidade de Brasília, como requisito parcial para obtenção do grau de Doutor em Literatura.
\end{abstract}

Orientadora: Prof ${ }^{\mathrm{a}}$. Dra ${ }^{\mathrm{a}}$. Sylvia Helena Cyntrão

Brasília, março de 2015 
TESE DE DOUTORADO

A CIDADE TODA EM CONTRAMÃO: UMA LEITURA DA HIPERMODERNIDADE NAS CANÇÕES CONTEMPORÂNEAS DE CHICO

\title{
BANCA EXAMINADORA
}

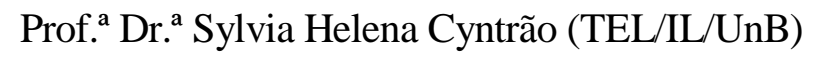 \\ (Presidente)
}

\author{
Prof. Dr. Fernando Fábio Fiorese Furtado (UFJF - MG) \\ (Membro externo)
}

Prof. Dr. Júlio César Valadão Diniz (PUC - RJ)

(Membro externo)

Prof. Dr. Enrique Huelva Unternbäumen (LET/IL/UnB)

(Membro interno)

Prof. Dr. Rogério de Silva Lima (TEL/IL/UnB)

(Membro interno)

Prof. ${ }^{a}$ Dr. ${ }^{a}$ Elga Pérez Laborde (TEL/IL/UnB)

(Membro suplente) 


\section{AGRADECIMENTOS}

Meu sincero agradecimento àqueles que muito contribuíram para $o$ desenvolvimento dessa pesquisa.

À minha família: meu pai, Eduardo Lourenço Marques, meu esposo, Jacaono Batista de Lima Júnior, e filha mais linda, Laura Marques de Lima - que o empenho de sua mãe sirva de exemplo e estímulo. Em especial à minha mãe, Sonia Regina Marques, por deixar sua casa pra cuidar da minha enquanto escrevia essa tese. Amo vocês, meus alicerces.

À querida professora e orientadora Sylvia Helena Cyntrão, pela parceria desde o mestrado. Obrigada, principalmente, pela confiança. Levo uma amiga para toda vida.

Aos membros da Banca, professores Fernando Fiorese, Júlio César Diniz, Enrique Huelva e Rogério Lima, pela disponibilidade e atenção dedicada ao meu estudo.

À CAPES, pela bolsa de estudos, o que possibilitou a minha dedicação exclusiva à pesquisa.

Aos professores que fizeram parte da minha formação como pessoa e profissional, desde meu ingresso na Universidade do Estado do Rio de Janeiro, transferência para a Universidade do Noroeste do Estado do Rio Grande do Sul, até a conclusão do curso de graduação, mestrado e ingresso no doutorado em Literatura na Universidade de Brasília.

À colega Gabrielle Raulino e ao meu sogro, professor Jacaono Batista de Lima.

Aos queridos Alexandre Nunes e Juliana Carvalho Nunes pela amizade e acolhida em Brasília.

Ao meu filho, meu príncipe-rei, Lucas Lima. Aquele que mudou minha vida, fez de mim um ser humano melhor e mostrou que posso amar mais e mais. Contigo "cada instante é sempre".

Sobretudo, agradeço sempre a Deus e a Mãe Aparecida. Apesar das provações, sigo acreditando na presença constante de vocês em cada segundo da minha existência. Meu muito obrigada. 
"Estou fazendo músicas novas e talvez sejam músicas tardias, não sei. Ou talvez eu já seja um sujeito tardio, do século passado".

Chico Buarque 


\section{RESUMO}

Esta pesquisa tem por objetivo identificar como o imaginário coletivo, em meio ao contexto hipermoderno, é representado a partir do simbólico construído nas letras do álbum Chico (2011), de Chico Buarque de Hollanda. Entendendo que música, comunicação, cultura e cotidiano estão intimamente interligados, e que, por isso, são essenciais para a compreensão das sociedades midiáticas e tecnológicas atuais, procurase interpretar as complexas relações entre eles por meio da repercussão dos signos musicais na sociedade, enquanto modelo de consumo e representação cultural. O estudo analítico que aqui é apresentado tem como referencial as reflexões de Gilles Lipovetsky sobre os contínuos movimentos de ruptura, deslocamentos e descontinuidades propiciados pelo século XX e sua investigação sobre os diferentes conceitos vinculados à hipermodernidade: as identidades, o consumo, a mídia, a globalização e os relacionamentos, atentando para a influência dos níveis social, político, geográfico e cultural na formação desses modelos, na sociedade ocidental. Desta forma, a mistura das canções populares e a densidade simbólica das letras poéticas também operam como elementos de significação cultural e estética que ajudam o indivíduo hipermoderno no resgate da fragmentação e na procura pelo caminho para a integração e a inteireza. O estudo textual das letras poéticas proposto verifica de que forma Chico Buarque, como um homem da cidade, conduz as questões existenciais que o fazem produzir no século XXI e que sentidos mobiliza na dinâmica multifacetada de sua criação. Considerar uma análise cronológica de alguns dados biográficos relevantes do artista possibilita reconhecer as transformações sofridas por ele ao longo do tempo e como a "persona", formada em meio à vida pessoal, passada na cidade do Rio de Janeiro, onde mora, é revelada como voz discursiva em sua obra. Compreendendo que a canção pode reverter o processo de afastamento/separação, redimensionando o processamento da realidade contemporânea, nesse último álbum, Chico Buarque recorre à memória, seja a memória poética da lírica de suas composições passadas ou as memórias da sua própria experiência existencial, como matéria das letras das canções, o que atualiza e alinha sua obra ao contexto hipermoderno.

Palavras-chave: hipermodernidade, cultura, identidade, canção, Chico Buarque de Hollanda. 


\begin{abstract}
This research aims at identifying the way the collective imagination is represented in the hypermodern context with the symbolism issued in the lyrics of the Chico (2011) album, by Chico Buarque de Hollanda. Knowing that music, communication, culture and daily life are intimately connected, and thus essential to the understanding of the current technological and media oriented societies, this paper's objective is to interpret the complex relations between them by analyzing the repercussions of the musical elements in the society as model of consumption and cultural representation. The analysis presented in this paper has as reference Gilles Lipovetsky's reflexions on the ongoing shifts, breakthrough movement, discontinuity provided by the $20^{\text {th }}$ century, hypermodernity concepts and its investigations: the identities, the consumption, the media, the globalization, and the relationships, paying attention to the social, political, geographical and cultural influences on the formation of these role models on the western society. This way, the hybridity of the popular music and the symbolic density of the poetic lyrics also operate as elements of cultural and aesthetic signification that help the hypermodern person to rescue the fragmentation and to look for the way to the integration and the completeness. The study of the poetic lyrics verifies in which ways the artist, as a man of the city, conducts the existential questions that help him produce in the $21^{\text {st }}$ century, and which senses he mobilizes in the multifaceted approach of his work. It's also possible to recognize the changes the artist has gone through throughout time by the chronological analysis of some of his relevant biographic data, and the way his "persona", formed in midst of his personal life, lived in the city of Rio de Janeiro, where he lives, is revealed as discursive voice in his work. Understanding that the song may reverse the process of estrangement/separation, resizing the way contemporary reality is processed, in his last album Chico Buarque appeals to the memory (either the poetic memory of the lyrics in his past compositions or his own personal existential memories) as subject of his songs' lyrics, which refreshes and align his work to the hypermodern context.
\end{abstract}

Keywords: hypermodernity, culture, identity, song, Chico Buarque de Hollanda. 
SUMÁRIO

INTRODUÇÃO

1. A CANÇÃO E A FORMAÇÃO DA CULTURA BRASILEIRA........................................ 18

1.1 A história da canção como construção social........................................................................ 19

1.2 A Música Popular Brasileira: mercado, mídia e consumo........................................................... 35

2. O LUGAR HIPERMODERNO: O PARADOXO DA CULTURA MUNDO E AS TRÊS ONDAS DE DESCONTINUIDADE

3. CHICO BUARQUE E O HOMEM DA CULTURA-MUNDO ........................................... 70

4. OS TEMPOS “HIPER” NAS CANÇÕES DE CHICO (2011) ………………………........... 92

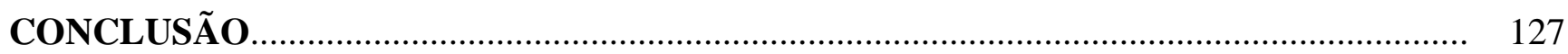

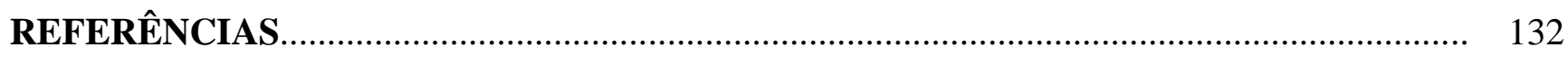

REFERÊNCIAS DISCOGRÁFICAS.................................................................................... 137

ANEXOS 


\section{INTRODUÇÃO}

Essa pesquisa investiga como o imaginário coletivo dentro da Música Popular Brasileira reflete o contexto hipermoderno. $O$ corpus selecionado para $\mathrm{o}$ desenvolvimento dessas reflexões é o último álbum de Chico Buarque de Hollanda, intitulado Chico (2011).

A imagem da "cidade toda em contramão", presente na letra de "Querido Diário" e que compõe o título dessa tese, estabelece uma leitura acerca do trânsito poético do artista, tanto pela 'mão' desse trânsito, compreendida enquanto ideologia textual latente (a memória das composições passadas), quanto pela sua 'contramão', enquanto meio externalizado (a memória das experiências existenciais), que viabiliza a conformação da mão dupla dialética. As análises da lírica das canções que compõem essa pesquisa demonstram como o trânsito das ideias e dos ideais, seja pela "mão", seja pela "contramão", é representado pela voz que fala em um panorama de fraturas ${ }^{1}$.

Baseado em variados aspectos, o século XX é marcado pelos contínuos movimentos de ruptura, deslocamentos e descontinuidades. Os antigos laços com o velho mundo deram lugar a uma dinâmica multifacetada, do mesmo modo que toda essa desestruturação deu origem à desordem contemporânea. Ao se libertar de qualquer diretriz ou referências do passado, o indivíduo sente um mal-estar ligado à desorientação frente um espaço em contínua e veloz mutação. Esse é o tempo hipermoderno que ainda procura um sentido para si, um novo modelo de composição.

O mundo carece de novas regulações, nesse contexto que o desejo de dar uma finalidade à existência produz ações que investem em novas formas de sensibilidade como verdadeiros sinais da necessidade de uma vida menos dilacerada, mais harmoniosa e equilibrada.

Os filósofos Gilles Lipovetsky e Jean Serroy (2011) atribuem a desarticulação contemporânea às fraturas nos três grandes marcos referentes aos domínios da arte, dos costumes e da economia que comandam a organização do mundo e da cultura. A primeira fratura trata do liberalismo artístico total, observa-se a destruição da arte

\footnotetext{
${ }^{1}$ As ideias relativas ao "trânsito, mão e contramão" na canção de Chico Buarque foram apresentadas por Sylvia Cyntrão na comunicação "Mão e contramão na obra de Chico Buarque de Hollanda" no XVII Congresso Internacional de Humanidades Brasil-Chile (outubro de 2014) com apoio da FINATEC.
} 
burguesa e dos códigos das formas expressivas tradicionais. É o triunfo da "arte contemporânea". O liberalismo cultural marca a segunda fratura, a partir de 1960. Vêse a escalada do hiperindividualismo apoiado no abalo das normas da vida rotineira, dos ideais burgueses e dos relacionamentos entre os sexos. A terceira e última fratura evidencia o liberalismo econômico na virada dos anos 1970-80.

O fenômeno do neoliberalismo, sob comando do capitalismo "desenquadrado" e do "mercado-rei", desmantela o sistema de regulamentações, os controles administrativos e as barreiras protecionistas. A sociedade neoliberal é edificada no centro da hipermodernidade caracterizada por movimentos de hiperbolização dos próprios princípios da modernidade e pelo enorme avanço dos fenômenos tecnológicos, urbanos, artísticos, midiáticos e consumistas.

Ainda segundo Lipovetsky e Serroy (2011, p. 128):

[...] com a globalização, há uma erosão das fronteiras e das barreiras geográficas, compressão do espaço-tempo, mas não desaparecimento das distâncias culturais. E, quanto mais os indivíduos têm acesso à cultura-mundo, mais experimentam a necessidade de defender suas identidades culturais e linguísticas.

Em outras palavras, a hipermodernidade por ser compreendida por uma radicalização da lógica modernista e de seus princípios formadores, a saber, o desenvolvimento científico, a democracia, o individualismo e a economia liberal.

O sujeito hipermoderno tende a buscar em si mesmo as respostas para o sentido da vida. À medida que as respostas da religião, das ideologias políticas ou das ciências humanas não são mais satisfatórias nem têm a mesma importância no espaço público, a felicidade deixa de ser considerada uma promessa para o futuro, sendo os indivíduos levados a alcançá-la sozinhos, no presente e no rompimento com todo vínculo ideológico.

Permeada de nuances e paradoxos, a cultura-mundo, ainda que imediatista, relativista, racional e individualista, não despreza o legado histórico, tampouco se mostra indiferente diante das injustiças, pois busca no resgate da religiosidade o alívio para o desconforto e estimula a participação política e social. Diante dessas contradições, faz-se necessário analisar: qual é a cultura que caracteriza o mundo contemporâneo? De que modo ela transita entre o capitalismo, a globalização, o consumismo, a internet, o individualismo - alguns dos eixos do novo mundo? 
Nesse caso, entender o texto artístico como objeto de investigação significa desvendar as ligações ocultas do sujeito com o contexto presente no mundo real e imaginário que o permeia, levando em conta que não é possível definir com exatidão o sentido de uma forma simbólica em sua representação, já que, de acordo com o momento histórico, ela está à mercê do fluxo do imaginário que a ressignifica. Assim sendo, a vida orgânica do texto provoca relações externas, inclusive a interferência do leitor que estimulará os sentidos para mover toda rede simbólica da qual o texto é construído. Nesse contexto, "a interpretação se mostra discursivamente como necessidade da relação da língua com a história, ideologicamente constituída" (CYNTRÃO, 2004, p. 42).

Observamos, então, a poesia como representação simbólica que desmitifica e ressignifica o humano, retrato de um patrimônio cultural coletivo. Por sua vez, a canção assume um novo papel possível de manifestação da poesia que se alimenta tanto da cultura erudita quanto do que é espontâneo e corriqueiro, no processo de desalienação que se segue.

Por sua contribuição para o levantamento do atual cenário da produção poética no país e para o desenvolvimento desta tese, também merecem destaque as atividades do Grupo de Estudos Poesia contemporânea: representação e crítica (VIVOVERSO), orientado pela professora Sylvia Cyntrão, do Departamento de Teoria Literária e Literaturas - TEL, da Universidade de Brasília - UnB, grupo do qual sou integrante. A pesquisa do grupo serviu como incentivadora na continuidade da busca pelo entendimento desse fazer poético contemporâneo. A análise contida nessa tese visa também contribuir para o avanço da pesquisa realizada pelo grupo, através do conceito de que as dúvidas existenciais, tema de maior preocupação do eu-poético, propiciadas pelas relações do sujeito com seu semelhante e o contexto que os envolve, são frutos do mundo hipermoderno.

A relação entre a canção e os sentimentos humanos também é fonte para o mercado cultural de massas que estimula uma maior aproximação do público com a audição da música popular. Ao ser esteticamente entendida como obra literária, a letra da canção traduz o imaginário presente no cotidiano do sujeito, nas suas aspirações e angústias existenciais que serão investigados neste estudo.

A partir desse aspecto, a poesia torna-se indissociável da música, como na lírica trovadoresca, não servindo apenas para ser lida, mas para ser lida e cantada, o que não 
impede que as letras das canções adquiram status de texto poético em certo segmento do gênero graças à sua indiscutível qualidade literária, assim como acontece com as letras das canções de Chico Buarque de Hollanda, como será demonstrado na sequência desta pesquisa.

As análises das letras poéticas de Chico Buarque feitas aqui visam aplicar a lógica diferenciada de análise textual integrante da teoria do dialogismo de Bakhtin que envolve "as relações inter e intratextuais estabelecidas entre sujeito, inconsciente e ideologia, ou melhor, entre o eu e os outros; o particular subjetivo e o intersubjetivo que o compõe, justamente pela via das absorções dialógicas". Sendo assim, "somente por meio desta concepção dialógica da linguagem, que é criação do homem, torna-se significativa a leitura de textos contemporaneamente" (CYNTRÃO, 2004, p. 47).

Desenvolvendo uma espécie de mosaico do imaginário, revelador das questões sociais e suas consequências existenciais, por meio dos seus textos, os cancionistas da Música Popular Brasileira têm explorado, sob a luz das ciências literárias, a plurivocidade desse fenômeno cultural e linguístico que é a canção. Nesse sentido, é necessária uma análise, quanto aos aspectos da história deste gênero e sua influência no contexto brasileiro, enquanto instrumento que dá voz aos sentimentos e angústias, revelando o que existe de mais íntimo no ser.

Isso posto, considerando o princípio das relações entre a intentio autoris (a intenção do autor), a intentio operis (a intenção do próprio texto) e a intentio lectoris (a intenção do leitor), tríade analítica estabelecida por Eco (1990), que, a partir do texto poético de Chico Buarque, serão realizadas as análises interpretativas dessa tese.

Realiza-se dessa forma, uma investigação que colabora com o entendimento desse fazer poético contemporâneo, observando que a apreensão das falas de representação e transcendência que o compõem permeia-se "das implicações globais de integração e estranhamento do homem em seu meio. Os índices de contemporaneidade e universalidade na obra poética são, portanto, identificados a partir da leitura do 'homem', situado em tempo e espaço determinados”' (CYNTRÃO, 2004, p.10).

Para tanto, incorpora-se o conceito desenvolvido por Lipovetsky, a "hipermodernidade", com o objetivo de melhor esclarecer as tendências do pensamento contemporâneo diante da cultura-mundo. Delineando o retrato dos novos tempos, edificam-se quatro eixos estruturantes que alicerçam o mundo hipermoderno. São eles: 
[...] o hipercapitalismo, força motriz da globalização financeira; a hipertecnicização, grau superlativo da universalidade técnica moderna; o hiperindividualismo, concretizando a espiral do átomo individual daí em diante desprendido das coerções comunitárias à antiga; o hiperconsumo, forma hipertrofiada e exponencial do hedonismo mercantil. Essas lógicas em constantes interações compõem um universo dominado pela tecnicização universalista, a desterritorialização acelerada e uma crescente comercialização planetarizada. (LIPOVETSKY; SERROY, 2011, p. 32)

Conforme o filósofo, "a primeira modernidade era extrema por causa do ideológico-político; a que chega é aquém do político, pela via da tecnologia, da mídia, da economia, do urbanismo, do consumo, das patologias individuais". Imerso nesse contexto, a partir das vozes diferenciadas e ressignificadas pelos cancionistas, o ser "hipermoderno" expõe-se na retomada da difícil integração da realização do desejo pessoal no seu papel social inexorável. Portanto, a hipermodernidade é integradora (2004, p. 56). Essa tese discute e identifica, nos textos selecionados, a tendência apontada.

Lipovetsky fala de seu lugar de cidadão francês, no entanto é relevante salientar que suas considerações sobre a sociedade atual podem ser migradas para as análises das realidades expostas por Chico Buarque nas letras selecionadas do álbum Chico. Essas canções, como observaremos adiante, visam uma reflexão existencial da qual o sujeito contemporâneo sofre influência, sobretudo pela ação das mídias que homogeneizam comportamentos, e isso independente de nacionalidade.

A cultura, por sua vez, constitui-se num regime inédito na medida em que o novo ciclo de modernidade recompõe o mundo: a era hipermoderna alterou profundamente o relevo, o sentido, o contexto social e econômico da cultura. De acordo com Lipovetsky e Serroy (2011, p. 7), “esta não pode mais ser considerada como uma superestrutura de signos, como o aroma e a decoração do mundo real: ela se tornou mundo, uma cultura-mundo, a do tecnocapitalismo planetário, das indústrias culturais, do consumismo total, das mídias e das redes digitais".

Passou o tempo em que se entendia a cultura enquanto um tema coerente e completo, onde havia uma grande oposição entre cultura popular e cultura erudita. Edifica-se um universo em que a cultura, unida à indústria mercantil, descobre seu caráter universal, infiltrando-se em todas as esferas da atividade:

Ao mundo de ontem, no qual a cultura era um sistema de signos comandados pela lutas simbólicas entre grupos sociais e organizava-se em torno de pontos de referência sagrados, criadores de um universo 
estável e particular, sucede o da economia política da cultura, da produção cultural proliferante, indefinidamente renovada. Não mais o cosmo fixo da unidade, do sentido último, das classificações hierarquizadas, mas o das redes, dos fluxos, da moda, do mercado sem limite nem centro de referência. Nos tempos hipermodernos, a cultura tornou-se um mundo cuja circunferência está em toda parte e o centro em parte alguma. (LIPOVETSKY; SERROY, 2011, p. 8)

Por outro lado, a cultura de massa desenvolve, dentro de uma concepção industrial que visa rentabilidade, uma enorme variedade de mensagens culturais que se caracterizam enquanto modelo mais importante de cultura da sociedade como um todo, propagando no espírito dos indivíduos uma ressonância de sentimentos e ideias. Assim, os sujeitos criadores reagem frente aos materiais da cultura que lhes são fornecidos, traduzindo-os constantemente em suas obras.

O rádio e a televisão, além da Internet, são elementos essenciais da cultura de midiática. Seu controle até mesmo sobre a educação dos indivíduos deve-se ao seu grande poder de acesso e inserção no meio da vida cotidiana familiar. Por sua vez, a canção no Brasil tem grande difusão e uma participação significativa em nosso cotidiano. O interesse em compreender as engrenagens dessa arte é cada vez maior: são livros, cursos, pesquisas com os mais variados objetivos que ganham espaço e credibilidade como objetos de estudo da canção popular. Ademais de sua notória popularidade e grande produção, enquanto fonte privilegiada de entretenimento, a canção foi reconhecida como um dos mais importantes indicativos e agentes modificadores das tradições e práticas sociais, tornando-se um elemento cultural diferenciado, devido ao seu poder de representação da sociedade do país.

Desde a metade da década de 1960, acirrou-se nos meios acadêmicos o debate sobre a relevância literária da música popular contemporânea. Além do domínio primário da performance ao vivo ou da gravação, o domínio das letras impressas também são avaliados, pois constituem um "modo secundário de comunicação artística que possui, em certos casos, pertinência literária". As letras impressas, para além da sua função informativa e de auxílio para memorização, podem servir de ferramenta para reflexão sobre comportamentos culturais em transformação. Ao tornar o texto musical um artefato impresso, o compositor revela intenções de escritor, evidenciando as semelhanças entre literatura e música popular, ao mesmo tempo que o crítico poderá fazer menção a temáticas, alusões, recursos linguísticos, sem descaracterizar o conjunto músico-poético original (PERRONE, 2013, p. 92-93). A obra de Chico Buarque é 
exemplar graças a uma multiplicidade de vozes que se articulam com o objetivo de submeter texto e leitor em um determinado contexto social e histórico, capaz de estabelecer sentidos e interpretações do Brasil.

Esse entendimento da capacidade da canção popular brasileira, consciente ou inconscientemente por parte dos artistas, para agregar, criticar e transformar os costumes e pensamentos da sociedade, levou ao desenvolvimento dessa pesquisa. Segundo Moutinho (2011), podemos afirmar que a letra da música representa a literatura nacional que realmente se estabeleceu em termos populares, sendo a canção popular brasileira capaz, inclusive, de afirmar-se apesar da invasão da música norteamericana presente em quase todo o mundo graças à sua força tecnológica e midiática.

Com a hiperindividualização e a livre conexão com o planeta por meio do desenvolvimento da comunicação e das hipermídias, a relação com o tempo e com a distância são modificadas, dominam a simultaneidade e o imediatismo: "a culturamundo é a da compressão do tempo e do encolhimento do espaço", com ela os indivíduos tomam mais consciência da globalização dos perigos, "afirma-se a cosmopolitização dos medos e das imaginações, das emoções e dos modos de vida" (LIPOVETSKY; SERROY, 2011, p. 15-16). No entanto, surgem os paradoxos hipermodernos pois, se de um lado a cultura-mundo retrata o desenvolvimento do mundo tecnológico, por outro lado, o mesmo mundo tecnomercantil contribui para renovar as questões culturais, retomando a problemática das identidades coletivas, do vínculo às origens, das heranças, das línguas nacionais, dos ideais religiosos etc. Se a cultura mundial hoje é marcada por uma enorme onda de homogeneização, graças à influência do mercado e das indústrias culturais, também vê-se expandirem-se os movimentos em prol da diferença. À medida que o mundo globalizado avança, mais os particularismos culturais desejam afirmar-se. Uniformização globalitária e fragmentação cultural caminham lado a lado:

Se a cultura-mundo pacifica as democracias e reorganiza a experiência do espaço-tempo, fica evidente que ela é também o que desorganiza em grande escala as consciências, os modos de vida, as existências. O mundo hipermoderno está desorientado, inseguro, desestabilizado, não ocasionalmente, mas no cotidiano, de maneira estrutural e crônica. E isso é novo. (LIPOVETSKY; SERROY, 2011, p. 18)

No seio das democracias modernas surgem promessas e alternativas para as crises e tragédias comuns em qualquer sociedade. Eclode, então, a esperança num futuro radicalmente distinto e seguro. No entanto, não é o que se vê: quanto mais o primado do 
indivíduo e do mercado, alicerces do liberalismo moderno, dominam o mundo democrático, mais desamparado sente-se o sujeito frente à aniquilação dos pontos de referência coletivos. Nunca houve tanto acesso às informações e conhecimento acerca do mundo, mas, do mesmo modo, nunca a sensação de compreensão sobre esse mundo foi tão frágil e obscura. Ficam as perguntas que nem mesmo as ciências e as tecnologias podem responder: como será o futuro? Para onde caminhamos? Na hipermodernidade da cultura-mundo, a incerteza substitui a ordem dogmática das ideologias históricas.

Entendendo nesse contexto hipermoderno de falta de rituais, onde o indivíduo busca incessantemente uma zona de conforto que o isole dos enfrentamentos diante da realidade, observa-se o papel do artista, sobretudo o cancionista, como um ator essencial, devido à sua inserção nas variadas mídias populares, capaz de levar o sujeito "para fora de si", revelando os mistérios de crescer como ser humano.

Elegi o cancionista e sua obra literária, portanto, como matérias primas para esta pesquisa acerca dos diferentes conceitos vinculados à hipermodernidade: as identidades, o consumo, a mídia, a globalização e os relacionamentos, atentando para a influência dos níveis social, político, geográfico e cultural na formação desses modelos, na sociedade ocidental.

Quanto à delimitação do corpus, escolhi o compositor Chico Buarque de Hollanda, ícone da canção popular brasileira, devido ao alto lirismo existencial presente nas letras de suas canções quando trata dos relacionamentos e do comportamento humano. $\mathrm{O}$ conceito de hibridismo também é levado em conta nessa pesquisa. A mistura característica da experiência pós-moderna deixou marcas no mundo das artes por meio de um amplo hibridismo conceitual que possibilitou o intercâmbio de linguagens de distintas origens. Assim, a arte, a cultura de massa e a realidade virtual, se unem ao imenso aglomerado de tendências e vozes que compõem a rede de informações globais.

De acordo com Chistina Ramalho (2005, p. 93):

Como se vê, o processo global, definitivamente instaurado nos anos 90, modificou profundamente a relação Arte/Realidade, gerando um Hibridismo paradoxal, uma vez ser o mesmo passível tanto de reproduzir estruturas dominantes, dada sua proximidade com as linguagens midiáticas, como de se fazer instrumento para o tal revisionismo conceitual das práticas perversas do nosso sistema político-econômico mundial.

Dessa forma, a partir da análise das canções de Chico, de 2011, foi investigada a natureza híbrida das letras de "Querido diário" (2011), "Essa pequena” (2010), “Sem 
você 2" (2011), “Tipo um baião" (2011), "Nina" (2010), "Barafunda" (2010) e "Sinhá" (2010) por meio da observação descritivo/analítica dos significados que apontam pistas do que contemporaneamente circula no imaginário coletivo em meio ao contexto hipermoderno, representado a partir do simbólico presente nas letras do álbum, o que se dará efetivamente no quarto e último capítulo desse trabalho.

Antes das análises, no primeiro capítulo, "A canção e a formação da cultura brasileira”, será apresentado um histórico da canção enquanto elemento de construção social e o papel da Música Popular Brasileira em meio ao contexto de influência do mercado, da mídia e do consumo. As características artísticas de Chico Buarque de Hollanda, cuja trajetória produtiva já acumula mais de quarenta anos, também serão contempladas.

O segundo capítulo "O lugar hipermoderno: o paradoxo da cultura mundo e as três ondas de descontinuidade" tratará das origens do conceito de hipermodernidade, apresentando o paradoxo da Cultura-Mundo - a erosão das fronteiras e a defesa das identidades culturais. Também serão discutidas as três ondas de descontinuidade defendidas por Lipovetsky e Serroy (2011): do liberalismo artístico e cultural, até a sociedade hipermoderna e suas implicações no simbólico presente nas canções de Chico Buarque.

No terceiro capítulo, "Chico Buarque e o homem da Cultura-Mundo", será observado, por meio de bibliografia selecionada, a figura do artista como sujeito produtor de cultura na tradução contemporânea da tradição lírica da literatura ocidental. E ainda, que a obra de Chico Buarque, considerado uma das mais importantes expressões da lírica brasileira no século XX, é composta por marcas da contextualidade histórica, social e política do Brasil e pelo planejamento de um projeto poético de criação próprio, de onde se entende a relevância literária das suas composições. Tudo isso por meio de um universo semântico particular que o torna porta-voz lírico das angústias sociais e políticas do homem contemporâneo.

A análise das canções, realizada no quarto capítulo "Os tempos 'hiper' nas canções de Chico (2011)", evidenciará a influência do contexto hipermoderno, apresentado em momento anterior, nas imagens poéticas das letras.

Após esse mergulho orientado pelo instrumental teórico pode-se chegar às conclusões oriundas da pesquisa, a fim de analisar o "modus" de interferência do 
panorama hipermoderno nos sentidos mobilizados pelas imagens de representação poética. 


\section{A CANÇÃO E A FORMAÇÃO DA CULTURA BRASILEIRA}

O reencontro entre música e poesia no contexto brasileiro se dá graças à invasão da MPB por um grupo poético da geração de 1960 e proporcionou, além do retorno da oralidade do poema, a utilização de um novo e poderoso canal de comunicação de massa. O canal de comunicação gráfico torna-se defasado frente aos apelos sonoros e visuais dos canais de comunicação de massa. Abordando a relação da música popular com a literatura, Silva (2010, p. 29) afirma que se trata de "defender a invasão do setor por um grupo de poetas da geração de 1960 que elege a MPB e não o livro como canal de comunicação literária. Refiro-me à presença da poesia na MPB, que produziu o poema musicado, e não à produção paraliterária própria do setor”.

As diversas representações de cunho marcadamente social, político e filosófico presentes nas letras das canções podem nos propiciar uma abertura para a compreensão de processos histórico-culturais. Nessa perspectiva, o ato de interpretar incorpora-se ao processo criativo e contextual do qual a canção surge. São estabelecidas variadas relações com as expressões artísticas na medida em que se toma consciência da sua representatividade na vida cotidiana. Nesse sentido, a canção de Chico Buarque coloca em evidência a experiência e contextos vividos ao tratar diferentes dimensões do falar, do pensar, do escrever, deste e de outros tempos. Isso quer dizer que no discurso do sujeito simples podem se agregar outras falas políticas, filosóficas, ideológicas que instigam o movimento de interpretação.

Conforme Bornheim, o importante no processo de interpretação seria:

[...] estabelecer uma espécie de "afinidade" que propiciasse um "caminhar com" a linguagem musical. Esse caminhar seria estar disposto a compreender o sentido de tal linguagem através de uma flexibilidade de escuta, ou melhor, de uma atitude participativa que nos envolve com as práticas musicais, movimentando nossa sensibilidade e fazendo-nos jogar, dançar, transformar, explorar diferentes caminhos. (2001, apud PAZ, 2011, p. 28).

Precisa-se, então, partir do pressuposto de que o sujeito possui educação musical, em lato sensu, visto que está em contato com a música imersa em padrões culturais e históricos. Ainda segundo Bornheim, "ouvir música pressupõe um comportamento cultural" (2001, apud PAZ, 2011, p. 28): 
[...] para que a música possa realmente ser pensada, para que se consiga perceber o quanto ela significa e o papel que desempenha, faz-se indispensável antes de tudo o abandono daquele subjetivismo intelectual que define o homem contemporâneo e inferioriza toda a esfera da sensibilidade. (BORNHEIM, 2001, apud PAZ, 2011, p. 34)

Desse modo, a obra lírica é definida como expressão subjetiva de um eu-lírico, sem desconsiderar o panorama de realidade pressuposta no qual está imerso. Toda pessoa deve assumir uma posição dentro do discurso cultural que lhe concede a identidade histórica de sujeito linguístico e social. Para "desfrutar da condição humana [...] o indivíduo precisa exercer a condição linguística de locutor" que "permite acessar o inventário cultural da experiência humana, tornando-o fluxo semiotizante de suas próprias experiências" (SILVA, 2010, p. 31).

\subsection{A história da canção como construção social}

Um dos primeiros estudos científicos significativos sobre a música popular, realizado por Adorno em 1941, observou o caráter das músicas populares e a função das agências na estandartização de formatos musicais ("On radio music"). Em seguida, veio a análise de Peatman sobre os diferentes temas presentes nas letras das canções populares ("Radio and popular music" - 1944). Segundo ele, todas abordavam o tema "romance/amor", sendo divididas em três tipos: "felizes no amor"; "frustrados no amor"; “canções com interesse sexual". Em 1957, Riesman ("Listen to popular music") estudou a forma como as músicas e as opiniões sobre elas são utilizadas como formas de comunicação, e Johnston e Katz ("Youth and popular music: a study in the sociology of taste") buscaram desvendar as questões do gosto por certo tipo de produções musicais.

Os estudos de Horton (1957) e Carey (1969) sobre as letras das canções também foram significativos. Horton buscou dimensionar a função da música romântica, afirmando que as letras fornecem padrões de atitudes e comportamentos diante dos novos modelos do mundo. Doze anos depois, a análise de Carey evidenciou a ocorrência de novas categorias temáticas que revelam a valorização da autonomia individual frente um contexto imerso em convenções. O sujeito aparece disposto a criar seu próprio mundo, baseado num novo sistema de crenças que serviram de alicerce para os variados movimentos sociais de hoje. 
No caso da canção popular brasileira, durante muito tempo, seus estudos versavam sobre uma perspectiva histórica e biográfica. No entanto, a partir dos anos 1960, começaram a ser desenvolvidas abordagens analíticas que procuravam pontos de vista mais específicos e particularizados acerca da canção popular. A obra Música popular e moderna poesia brasileira, de Affonso Romano de Sant'Anna, apresenta grande valor acerca das discussões iniciais sobre a MPB, ajudando a solidificar o reconhecimento acadêmico da qualidade poética das composições de artistas como Noel Rosa, Ary Barroso, Caetano Veloso e Chico Buarque.

Sant'Anna também traça um panorama dos principais movimentos poéticos, e estilos literários brasileiros, e da expressão poética nas canções populares, perfazendo um caminho que compreende desde o modernismo até a poesia marginal dos anos de 1970. Seu trabalho teve fundamental importância no combate à resistência ligada ao reconhecimento da capacidade poética dos maiores compositores brasileiros, abrindo caminho, principalmente na área de letras, para a realização de trabalhos de pesquisa acadêmicos que têm a música popular brasileira como objeto.

Anazildo Vasconcelos da Silva é outro estudioso da canção popular brasileira no âmbito dos estudos literários. Pioneiro no estudo da poética de Chico Buarque, publicou em 1974 o primeiro ensaio sobre a obra do então jovem artista, A poética de Chico Buarque, que, em sua segunda edição de 1980, recebeu o título de A poética e a nova poética de Chico Buarque. Silva segue desenvolvendo estudos críticos sobre a obra de Chico, cuja produção poética ganhou mais relevância em uma variedade de análises e interpretações.

Essa postura se desenvolve enquanto pesquisa nas universidades, recebendo a importante contribuição de Luiz Tatit e seus estudos acerca da semiótica da canção. Tal projeto entoativo, para se concretizar, necessita da voz e da figura funcional do intérprete.

Nesse caminho, estudos ligados à voz e à performance têm ganhado espaço na pesquisa e na crítica sobre a canção popular, o que leva a considerar o papel do intérprete na própria evolução histórica da canção.

A performance está ligada às condições de expressão e da percepção, ela pressupõe um ato de comunicação em si, cuja palavra representa a presença imediata e concreta de participantes nessa ação. Por seu caráter antropológico e não histórico a performance "atualiza virtualidades mais ou menos numerosas, sentidas com maior ou 
menor clareza”. Então, a performance é parte privilegiada da recepção onde o enunciado é de fato recebido. Esse impulso pela percepção faz nascer no sujeito o desejo pela (re)construção num processo de personalização da leitura que é livre de obstáculos internos, do próprio sujeito, e externos, presentes no meio cultural: “O eu só importa pelo que ele denota: a saber, que o encontro da obra e de seu leitor é por natureza estritamente individual, mesmo se houver uma pluralidade de leitores no espaço e no tempo" (ZUMTHOR, 2007, p. 50-54).

Essa pesquisa aborda o trabalho de Chico Buarque que produziu em mais de quarenta anos de carreira uma obra rica em imagens e símbolos que acompanharam vários momentos históricos do país. Nesse sentido, o efeito e a força do seu lirismo resultam de um eu-poético sensível, em simbiose com a realidade seja do homem, da mulher, da vida em si, dos seus semelhantes, em seus diferentes tempos e espaços.

Em entrevista à revista Língua Portuguesa (2006), Chico comentou: "Todos deviam perceber que as letras não são poesia; elas se integram à música para compor uma canção. Talvez seja pedir demais”. Mesmo tendo declarado não se considerar um poeta, é fato que sua obra possui diferenciais ligados ao cuidado formal, ao conteúdo denso, ao alcance universal e à existência de uma tensão verbal vistos somente nos grandes poetas.

Chico Buarque domina a habilidade de trabalhar com diferentes linguagens e conceitos, tanto contemporâneos quanto tradicionais. Essa é uma característica própria do sujeito hipermoderno diante da velocidade de comunicação, onde maior que o sentimento de decepção, é a inquietação rotineira que instiga o artista. A satisfação nunca é plena, sempre está anexada a novas e urgentes necessidades, tudo isso em meio a um desassossego presente em todas as áreas: no trabalho, na alimentação, na saúde, na problemática do meio ambiente, entre outras. A sensação de nostalgia do passado prevalece, e revela-se nas letras poéticas analisadas, assim como o avanço dos sentimentos de medo e insegurança diante de um amanhã cada vez mais incerto. Sendo assim, as análises dessas letras poéticas, imersas em pleno tempo hipermoderno, colaboram para responder a questão fundamental de como a literatura contribui para criar, recriar, afirmar e negar o estatuto do indivíduo.

$\mathrm{Na}$ trajetória da humanidade a escrita surge como "uma revolta contra o tempo". A literatura provém desse propósito compartilhado entre poesia e escrita: ambas tentam "arrancar os discursos à fragilidade de sua condição temporal” (ZUMTHOR, 2007, p. 
49). Seguindo essa tendência, a prática poética detém o impulso primitivo para liberar a linguagem do tempo biológico. Ligada à função comunicativa e representativa das emoções, comportamentos e desejos do sujeito, a linguagem está incorporada ao tempo biológico e, ainda que incapaz de o dominar ou banir, dissipa-se nele nesse esforço vital para resgatar nossas palavras da fugacidade do tempo que as consome. Tal processo é capaz de despertar uma consciência capaz de materializar-se nas letras das canções.

Chico consegue inovar ainda mais ao reciclar conceitos antigos, tornando-os legítimos nos novos tempos. Sempre revelando o humano, quer por meio do lirismo, do humor, do drama ou da tragédia, o poeta está atento às angústias dos novos tempos, que também são suas, demonstrando que qualquer expressão literária contém nos signos usados a marca do tempo em que foi produzida. Seu último trabalho musical, Chico, segue essa tendência: outros tempos, outras canções. Mas todas com uma pitada de nostalgia diante de modelos que ficaram no passado e que ainda fazem sentido para o assombrado homem contemporâneo. Conforme palavras do artista: "Estou fazendo músicas novas e talvez sejam músicas tardias, não sei. Ou talvez eu já seja um sujeito tardio, do século passado" (Revista Trip, 2006).

Cumpre-se observar nesse estudo que, apesar de todas as mudanças que alteraram as antigas estruturas sociais, a canção de Chico produzida no século XXI ainda é entendida como uma forma de reação, não mais contra regimes políticos, mas, desta vez, contra a desvalorização da tradição cultural nacional dos tempos atuais. Conforme podemos observar na letra de "Tipo um baião":

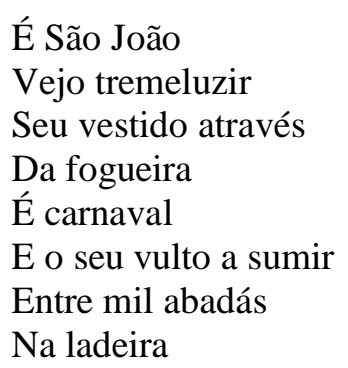

Nesse processo, a flexibilidade espontânea e o alcance da linguagem musical possibilitam o diálogo entre as mais variadas expressões artísticas que se fazem presentes no processo de representação da paisagem sonora contemporânea. Sendo assim, todos esses discursos artísticos têm como função reproduzir o panorama da vida cotidiana. Tal prática preocupa-se em considerar expressões de outras culturas, sem excluir o que não se encaixa perfeitamente no sistema. 
Pode-se entender que a miscigenação típica da música popular é reforçada pelo desenvolvimento tecnológico e midiático, pela globalização e pela presença cada vez mais forte da música no cotidiano cultural - ela está no rádio, na televisão, no cinema, na Internet, em escolas, festivais e concertos públicos - tornando-se "uma das expressões naturais da vida musical urbana do século XX” (PAZ, 2011, p. 35). Essa mistura também aparece nas letras de Chico Buarque por meio da combinação de diferentes elementos culturais, como "Nina":

Nina anseia por me conhecer em breve

Me levar para a noite de Moscou

Sempre que esta valsa toca

Fecho os olhos, bebo alguma vodca

E vou

E "Essa pequena":

Às vezes ela pinta a boca e sai

Fique à vontade, eu digo, take your time

Sinto que ainda vou penar com essa pequena, mas

O blues já valeu a pena

Tecendo o panorama até agora apresentado, a partir dos anos 1980, os estudos musicais tiveram maior liberdade para compor os cursos nas áreas das ciências sociais e humanas, revelando seu papel na formação das realidades sociais em temas como a identidade, a subjetividade e a experiência do sujeito cultural. Será observado como Chico Buarque participou do processo de abertura e apreensão desse novo cenário.

A canção popular brasileira tornou-se, no decorrer do século $\mathrm{XX}$, uma das mais importantes formas de manifestação artística. Esses cem anos foram representativos para a criação, consolidação e propagação de uma forma artística capaz de edificar a identidade sonora da nação, dando voz às temáticas humanas por meio de duas séries ou sistemas semióticos: a melodia e a letra.

A presença do corpo e da voz sempre norteou a produção musical no Brasil. Nossa música popular sempre esteve conectada à dança, ao ritmo e à melodia, que serviram, inclusive, de alicerce ao desenvolvimento estético da música erudita: "Em todos os períodos, desde o descobrimento, a percussão e a oralidade vêm engendrando a sonoridade do país, ora como manifestação crua, ora como matéria prima da criação musical, ora como fator étnico ou regional, ora como contenção dos impulsos abstratos peculiares à linguagem musical" (TATIT, 2004, p. 19). As principais diretrizes da sonoridade brasileira nascem dos "batuques negros" que, apesar de repletos de signos 
religiosos, tinham um caráter de rito social aceito pelas autoridades brasileiras em tempos de escravidão. Esses rituais já contavam com a presença das melodias e violas dos descendentes de europeus, de modo que não se pode negar a importante influência branca em sua realização.

De acordo com Williams (1992, p. 88-89):

Existem as modalidades que dependem básica ou inteiramente de materiais e objetos que são usados, manipulados e transformados pelo homem, e aquelas que dependem básica ou inteiramente de recursos inatos, inerentes ao homem. Na primeira categoria estão a pintura e a escultura, para cuja realização há a necessidade de tinta, pincel, tela, pedra, talhadeira. Na segunda, encontram-se, principalmente, as artes centradas no canto, na fala e no movimento corporal, fatores que são a essência, respectivamente, da música, da poesia e da dança.

As relações entre o corpo da canção (sons) e o espaço são dinâmicas, de modo que apresentam variações, evoluindo através da história. A abordagem mais comum em relação ao conceito de canção enfatiza sua posição histórica, embora seja constantemente cercada de indefinições conceituais acerca dos contornos de sua forma. De acordo com Vaz (2007, p.45): “A canção é tratada como uma entre as várias formas musicais (ou poéticas)".

No início do século XX, a questão nacionalista da sonoridade brasileira torna-se matéria de grande reflexão dos artistas e pensadores locais frequentadores dos terreiros de Tia Ciata $^{2}$ e de outras mulheres descendentes de escravos. O recente fim da escravidão gerava na comunidade negra a angústia por uma identidade dentro desse novo contexto social, de modo que coube a estas senhoras transferir para um espaço próprio no Rio de Janeiro a cultura e os costumes de seus ancestrais, que haviam inaugurado a sonoridade do país, agora impregnados de séculos de colonização ibérica. Essa mistura étnica e social mantida pelas tias em seus terreiros viu-se abalada por uma novidade fora do seu cotidiano: a vinda dos aparelhos de gravação para o Rio de

\footnotetext{
${ }^{2}$ Nascida livre em Salvador, no dia 23 de abril de 1854, foi, juntamente com outras tias baianas, a principal responsável pelo desenvolvimento e consolidação do samba no Brasil. Fundou, no fim do século XIX, na cidade do Rio de Janeiro, o primeiro Rancho de Samba do Brasil, o grupo Rosa Branca. Naquela época, o samba era proibido e para que houvesse as festas em sua casa, era necessário pedir autorização. Porém, tia Ciata tinha o aval da polícia através do marido funcionário público. Cada vez mais popular, participavam dos encontros um grande número de políticos, boêmios, músicos e batuqueiros. Nessas ocasiões, foi conhecido o primeiro samba gravado no Brasil em 1916, "Pelo Telefone", de Donga e Mauro de Almeida.
} 
Janeiro. Os primeiros sambistas receberam essas máquinas como a possibilidade de encontrar sua própria identidade. $O$ mercado de discos se expandia graças à simplicidade e popularidade dessas criações musicais, ao passo que seus intérpretes venciam as dificuldades financeiras e o risco de perda das suas obras no tempo com a falta de registro. Esse encontro mudou o destino da música no Brasil dando início ao que conhecemos atualmente como canção popular.

Nas primeiras décadas do século $\mathrm{XX}$, os sambas e as marchinhas urbanas projetavam-se além da época do carnaval com enorme poder de alcance. Tinha início a era dos cancionistas, os bambas da canção, capazes de conceber uma ideia de estética associada à noção de entretenimento e de se adaptar às novas tendências: o progresso tecnológico, o mercado, a moda etc. Por outro lado, quanto mais o mercado da canção se firmava enquanto grande representante do universo popular brasileiro, mais a música erudita rejeitava essa realidade, sobretudo pela resistência em reconhecer na canção desse período "um pensamento verdadeiramente musical" (TATIT, 2004, p. 41).

Nos anos quarenta e cinquenta o samba é marcado por uma crescente passionalização graças à influência do tango e do bolero, às marcas do longo período de guerra e, até mesmo, à desaceleração na produção carnavalesca. Em contrapartida, surge o baião de Luiz Gonzaga e a expansão do forró.

Em 1958, dá-se a primeira reviravolta musical no país, ocorrida no âmbito da canção popular, comprovando a maturidade da linguagem nascida nos terreiros do começo do século e a sua importância na concepção social e cultural do país, pouco a pouco adquirida: João Gilberto lança o disco Chega de Saudade, instaurando o movimento da Bossa Nova. Apesar de uma aparente ruptura frente a tudo que se sabia sobre canção, o novo estilo foi acolhido de imediato por grande parte do público, sobretudo o letrado: “A bossa nova de João Gilberto neutralizou as técnicas persuasivas do samba-canção, reduzindo o campo de inflexão vocal em proveito das formas temáticas, mais percussivas, de condução melódica. [...] nesse sentido, [...] atingiu uma espécie de grau zero da sonoridade brasileira” (TATIT, 2004, p. 49-50).

Personalidades da elite artística brasileira, pela primeira vez, passaram a transitar habitualmente pelo cenário da canção. Entre os mais conhecidos estão Tom Jobim, músico de formação erudita, além de principal compositor da Bossa Nova, e Vinicius de Moraes, que trocou a poesia pela composição das letras, tornando o fenômeno da canção em objeto de pesquisa acadêmica. No seu Música popular e moderna poesia 
brasileira (1978), Sant'Anna afirma que durante o movimento da Bossa Nova poesia e música popular participavam de um diálogo quase orgânico, graças à sua mesma base social de letrados e intelectualizados. Assim o autor explicava o aumento do interesse do meio acadêmico pelas composições da MPB.

Em meio ao conturbado contexto do regime político e do governo militar em 1964, alguns representantes do movimento da Bossa Nova, apoiados na força da canção enquanto domínio privilegiado para discutir os problemas sociais, no apoio estudantil e de outras artes, como o teatro e o cinema politizados, respondiam aos embates que angustiavam a sociedade da época. Dessa forma, "a música especificamente de protesto compunha com outras do mesmo estilo, mas menos direcionadas do ponto de vista ideológico, o gênero que passou a ser chamado de MPB” (TATIT, 2004, p. 52-53).

Nesse traçado, uma música jovem filiada ao rock internacional, no rastro do sucesso dos Beatles ${ }^{3}$, conquistava uma crescente repercussão no Brasil. Eram os praticantes do "iê-iê-iê" que resgatavam música para dançar, livre de engajamentos de ordem social ou política. Por outro lado, a Jovem Guarda, como ficou conhecida, abordava temas "alienados" para a época, alcançando seu propósito exclusivo de produzir para o mercado de discos.

Transmitidos pela tv, os Festivais da Canção, além do elenco fixo representado pela elite musical dos anos sessenta, abriam espaço para novos nomes que vieram a se consagrar como Chico Buarque, além de Milton Nascimento, Caetano Veloso e Gilberto Gil, para destacar três dos músicos de obra mais significativa na canção. No III Festival da Música Popular Brasileira, as canções finalistas "Domingo no Parque" e "Alegria, Alegria" disseminaram as figuras de Gilberto Gil e Caetano Veloso para todo o Brasil. Nesse contexto, os primeiros traços tropicalistas edificaram-se baseados na composição de letras com temática e elaboração inusitadas, somada à adoção de atitudes do "îe-iêiê" na mais importante vitrine da MPB. O Tropicalismo, ao revelar e prestigiar manifestações da cultura brasileira que permaneciam à margem das fronteiras artísticas e ideológicas, transitou pelo folclore, pelo "brega", pelo rock internacional e pelo "iê-iêiê" local, concebendo a imagem da "geleia geral brasileira" devido a esse diversificado agrupamento.

\footnotetext{
${ }^{3}$ Formada em Liverpool em 1960, a banda de rock britânica "The Beatles", composta por John Lennon, Paul McCartney, George Harrison e Ringo Starr, é um dos grupos musicais mais bem-sucedidos da história da música popular.
} 
É fato que a Bossa Nova e o Tropicalismo foram os principais representantes da moderna música brasileira responsáveis por reunir a variedade sonora característica das décadas que se seguiriam e as tendências estéticas que tornariam as leis do mercado sonoro mais maleáveis. No entanto, ao passo que a Bossa Nova promoveu o processo de seleção da música popular brasileira, o Tropicalismo realizou a mistura e a proliferação do referido gênero pelo mundo (TATIT, 2004, p. 57-58). Enquanto movimento musical o legado mais representativo do Tropicalismo foi a libertação estética e ideológica dos autores, intérpretes, arranjadores e produtores do mundo da canção, resultando em grande influência em praticamente todas as áreas artísticas no país.

Fonte de resistência num passado não muito distante, a música popular brasileira manteve seu sentido mais livre e corajoso, mas, por outro lado, também nutre uma das reservas mais ricas de afeto e sabedoria que ganhou o mundo, sobretudo a partir de 1964. De acordo com Arthur Nestrovski (2002, p. 15):

Entre os direitos inalienáveis que deveriam ser de todos nós, como diziam Jefferson e Adams há mais de dois séculos, estão a vida, a liberdade e a busca da felicidade. A vida é essa; a liberdade (pelo menos jurídica) existe. Já a busca da felicidade, no Brasil... como a felicidade é difícil. Por outro lado, existe a música popular brasileira.

Ao longo dos anos de 1970, quando se consolida a canção moderna, as empresas multinacionais de gravação e difusão aprimoravam suas técnicas em relação ao mercado de discos, racionalizando a produção em larga escala, baseadas em critérios oriundos da pesquisa junto a públicos-alvos. Nesse sentido, podemos observar o caso da música norte-americana que durante longo período inflacionou a sonoridade brasileira enquanto produto do mercado de discos. Com o tempo, o mercado aprende a sondar o ouvinte elaborando projetos de acordo com o gosto e as necessidades emocionais dos mais variados domínios da sociedade, em dado contexto local e temporal.

Os estudos latino-americanos sobre Comunicação e Cultura ganham forma na década de 1980 imersos num contexto de crescente avanço da cultura midiática na vida cotidiana e de preocupação sobre seus efeitos na cultura popular. Marcado pela lógica da globalização, o debate sobre a modernidade e a cultura midiática busca flexibilizar o ideal determinista de classe para um melhor entendimento das relações entre cultura e classe social, possibilitando o reconhecimento das culturas populares e da formação de identidades. A noção de cultura atinge o campo dos processos que constituem e transformam o social. 
Dessa forma, observamos:

[...] uma sincronização do tempo social expresso na música, que termina por se elaborar na escuta dessa música e desta paisagem sonora. [...] No entanto, as mudanças por que passam as mídias sonoras não dependem exclusivamente das tecnologias, mas sim dos códigos culturais que determinam o conjunto de valores que organizam internamente a sociedade, onde alguns estilos ou gêneros musicais parecem exprimir um tempo e seu espírito, uma sociedade, contendo os elementos sonoros próprios a ela [...]. Estas razões parecem suficientes para crer que a música - e dentre as músicas, a canção - seguirá como valioso testemunho do espírito do seu tempo. (VALENTE, 2002, apud PEREIRA, 2007, p. 166)

Compreender a tradição cultural significa analisá-la enquanto elemento formador contemporâneo, através de imagens do passado deliberadamente elaboradas para estabelecer ligações com o presente, dando-lhe sentidos.

Os anos de 1980 ainda foram marcados pela grande quantidade de bandas que configuraram a década do rock brasileiro. Mesmo que vinculadas ao mercado cultural fonográfico, destacaram-se pela irreverência e uso de temas do cotidiano. Os anos de governo militar no país representaram uma maior quantidade de inovações artísticas nesse grupo, de modo que o rock brasileiro destacou-se no cenário nacional numa época de forte evidência das bandas norte-americanas na mídia. Entre as diversas bandas, podemos destacar a Blitz, Os Paralamas do Sucesso, Barão Vermelho, Titãs e Legião Urbana. Nessa mesma época, coube aos produtores observar a carência do mercado de disco em relação às canções de temática simples e emotiva. O diminuto espaço do sentimental era representado pelas obras de Roberto Carlos e outras já estigmatizadas pelo termo "brega", que logo seria agravado por meio do sucesso das diversas duplas sertanejas representantes da sonoridade passional brasileira na passagem dos anos de 1980 para os de 1990. O quadro musical da época se completa com a difusão por todo o país, e consequente comercialização, dos grupos de axé e de pagode, esse último também fundado em raízes brasileiras e com grande proximidade com a fala popular.

Uma consolidação do produto estrangeiro, apesar de vantajosa financeiramente para o mercado, representaria "a eliminação sumária de dicções que a sociedade não pode perder sob pena de ver ameaçada a própria identidade. Algo assim como uma força de permanência que se manifesta até mesmo na adoção dos estilos e das modas passageiras" (TATIT, 2004, p. 233). Chico Buarque era um dos artistas que 
representavam em si essa força de permanência ao expressar um ponto de equilíbrio das dicções do Brasil. Observa-se a principal contradição do fim do século XX; a globalização foi, na verdade, o fator fundamental de valorização das forças locais, apesar do esforço para a formação de uma world music. Essa tendência centralizadora acabou por despertar o entusiasmo das manifestações artísticas regionais e pessoais que estavam adormecidas em seus locais de origem.

Nesse caminho, outros grupos foram apropriando-se de espaços mais expressivos no campo da sonoridade brasileira. $\mathrm{O}$ grande avanço técnico somado ao barateamento da gravação de discos possibilitou a fusão entre o que Luiz Tatit (2004) chama de "artistas de criação" e "artistas de mercado", resultando na concepção de personagens compatíveis com a dinâmica comercial como Arnaldo Antunes, Lenine, Carlinhos Brown, entre outros. Além desses, nomes importantes como Tom Zé e Luiz Melodia, que estavam fora do circuito musical devido aos poucos recursos materiais, alcançaram a devida projeção.

Ao falar do surgimento da canção brasileira, Tatit (2004, p. 70) começa a revelar a importância social desse gênero:

A canção brasileira, na forma que a conhecemos hoje, surgiu com o século XX e veio ao encontro do anseio de um vasto setor da população que sempre se caracterizou por desenvolver práticas ágrafas. Chegou como se fosse simplesmente uma outra forma de falar dos mesmos assuntos do dia-a-dia, com uma única diferença: as coisas ditas poderiam então ser reditas quase do mesmo jeito e até conservadas para a posteridade. Não é mera coincidência, portanto, que essa canção tenha se definido como forma de expressão artística no exato momento em que se tornou praticável o seu registro técnico. Ela constituiu, afinal, a porção da fala que merece ser gravada.

Essa característica foi observada, sobretudo, pelos autores da MPB que, em tempos do sonho por uma nova sociedade com identidade própria e autenticidade de valores, apostavam na recriação de uma música constituída em bases folclóricas e rurais, unida ao ideário de revolução político-social. Caracterizando esse movimento, as "canções de protesto", destinadas à conscientização das massas, continham uma atitude exclusivista que não pode ser atribuída a todos os representantes da MPB. Chico Buarque foi um deles.

Entendendo esse movimento como alicerce da canção brasileira nos dias de hoje, tal gesto atua na própria consciência dos compositores e cantores impulsionando-os, ao mesmo tempo, para a diversidade e para o requinte técnico e estético. 
Será demonstrado adiante como esse comportamento está ligado aos conceitos hipermodernos e aos diferentes contextos presentes nas "três ondas de descontinuidade" descritas por Lipovetsky e Serroy (2011), analisando de que forma essa orientação se mantém no século XXI a partir das representações presentes nas letras selecionadas de Chico, álbum contemporâneo de Chico Buarque que sustenta a função de instrumento de reação da cultura nacional perante as fortes influências globais rapidamente disseminadas pela cultura de massa.

Outra tendência que se manteve presente na cultura brasileira foi a assimilação. Seus processos de mistura se mostram presentes nos trabalhos antropológicos, sociológicos e históricos desenvolvidos no país, ganhando especial atenção do mundo simbólico brasileiro, representado por nossos pensadores e criadores.

Exaltada pelos agentes culturais, na canção popular, essa mistura se manifestou em sua forma híbrida reunindo melodia, letra e arranjo instrumental, assimilando diversas influências musicais e ideológicas como forma de enriquecimento para chegar ao produto atual totalmente compatível com o mercado da cultura midiática. Essa mistura foi, como vimos, promovida pelo projeto do Tropicalismo que fundou o que conhecemos como música pop nacional, ou seja, "a música acessível e comercial, aberta a influências as mais variadas possíveis, da música erudita ao baião, do bolero à canção napolitana, do ragtime ao próprio rock-and-roll, lançada em discos, partituras, rádios ou outros meios de comunicação de massa, qualquer que seja a época ou o estilo do artista" (Entrada "pop" na Enciclopédia da Música Brasileira: Popular, Erudita e Folclórica, 2. ed. São Paulo, Art Editora/PubliFolha, 1998, p. 637 apud TATIT, 2004, p. 213).

Enquanto produto cultural híbrido, devemos considerar a transitoriedade e complexidade inerentes à canção. Para analisá-la deve-se atentar muito mais às variações do que às permanências. Fundamentado na mistura e na multiplicidade, um conteúdo cultural híbrido origina ideias de fratura, deslocamento e transitividade. Tal conteúdo não é o resultado de um aspecto, tampouco se limita ao que é único, mas tende a se revelar por diversas facetas, cada uma delas idealizada por fontes diversas e pouco delineadas, visto que, dentro dos processos de mistura, deixaram de ser o que eram inicialmente.

Se por um lado determinadas análises dão ênfase às características individuais pertencentes a determinados objetos da cultura, por outro, o híbrido é levado pela instabilidade da mudança habitual. Sua configuração se aproxima de uma rede de 
contatos variados, pois, enquanto múltiplo e facetado, deve se distanciar da dualidade, do risco de ser reduzido a tal simplificação. Vargas (2007, p. 65) assim aborda essa questão:

Polifônico e dialógico por excelência, o hibridismo é um processo selvagem que rompe estabilidades teóricas, recepções padronizadas e esperanças de unidade semântica; mas, ao mesmo tempo, mostra-se docemente criativo por ter em si germes de novas alternativas para novas combinações. Ele provoca impactos e é sempre mutante. Como potencial celeiro de criações, mescla de matéria-prima e produto, seduz e fascina; da mesma forma que assusta pelo descontrole, meio próximo do absurdo, e pela tranquila capacidade de amalgamar estranhos. Desvairado, funda sobre si novas percepções. Por tudo isso, teleologias e universalismos se tornam estéreis ao seu contato.

Os movimentos de desterritorialização e refuncionalização dos variados elementos culturais e estéticos, provocados pelas tecnologias contemporâneas de comunicação e informação, forçaram o surgimento de comportamentos e objetos híbridos. Esse não é um contexto novo na América Latina, um território da instabilidade historicamente marcado pelo encontro de elementos culturais e semióticos distantes. Sua cultura é um "resultado temporário e peculiar dos dados culturais que lhes foram colocados, da dinâmica particular de seu processo de fusão, dos personagens ativos, dos materiais concretos e instrumentais trabalhados e do contexto sócio-histórico em que esses processos se deram”. Quanto mais profunda a análise de cada núcleo cultural, seja local, temporal ou linguístico, mais particularidades são encontradas, de modo que essa "equação de elementos sincretizados" tem se mostrado cada vez mais complexa, "pois cada um desses dados não está colocado no processo de hibridação de forma pura e 'substancial', mas já é ou foi objeto de outros contatos e misturas" (VARGAS, 2007, p.65-66).

Todo esse potencial híbrido também se manifesta por meio de uma linguagem esteticamente elaborada presente na canção popular. Diversos estudiosos analisaram a música popular latino-americana sob o ponto de vista do hibridismo, destacando seu processo global de criação, marcado pela alteração dos padrões europeus, africanos e indígenas. As adaptações, misturas, subversões são suas características emblemáticas: ritmos formam adaptados, instrumentos redescobertos e inventados, o sagrado se aproximou do mundano, do mesmo modo que o que era plebeu se apropriou do aristocrático, e assim por diante. 
No Brasil, essa dinâmica híbrida é ouvida nos samba-de-roda, e seus subgêneros, nas variações do maxixe, nos ritmos nordestinos: maracatu e baião. Esse movimento fica evidente na letra de "Tipo um Baião" onde as contradições do sertão brasileiro são representadas por meio dos acontecimentos que se intercalam. Será apresentado, a partir da narrativa amorosa, a exaltação de elementos típicos da cultura brasileira ("baião", "fogueira”, "São João", “carnaval”, "Gonzaga”), o que simboliza um dos principais paradoxos da cultura-mundo: a erosão das fronteiras e a compressão do espaço-tempo em oposição ao fenômeno de defesa das identidades culturais e linguísticas.

Segundo Muniz Sodré (1979, p. 24), “o Brasil é um dos lugares em que as mesclas criativas proporcionaram formas inusitadas de afirmação cultural em que o negro usava o sistema europeu e, ao mesmo tempo, mantinha seus padrões rítmicos”. As manifestações sonoras na América Latina não negam a influência dos aspectos políticos e simbólicos de um sistema musical dominante, no entanto o flexionam com a combinação de traços de outras origens. Se, num primeiro processo, as variações e misturas deram origem a novos modelos de criar, ouvir e entender a canção, agora vê-se como as tecnologias de produção e reprodução musicais confirmaram ainda mais seu caráter híbrido.

De grande importância na edificação da expressão musical contemporânea, os processos de hibridação, historicamente marcados pelo período colonial e de transição do século XIX para o XX, ainda hoje seguem determinando a primazia do movimento de mesclas e incorporações, apesar dos novos contornos culturais e materiais. No contexto brasileiro temos os reconhecidos casos da Bossa Nova, do Tropicalismo e do Manguebeat. De fato, essa proposta de atualização das músicas tradicionais é um exercício constante na América Latina, impulsionado pelo contexto da globalização. Em meio a uma variedade de ritmos e gêneros, é no território urbano, verdadeiras malhas de incorporação, que se dão os contatos mais produtivos com os elementos do interior, do litoral e de outras terras.

Como exemplo desse processo, vale citar a canção-manifesto "Tropicália" (1967) de Caetano Veloso, pertencente ao Tropicalismo, movimento ocorrido no final dos anos de 1960 que inaugurou a estética sincretista pós-moderna na canção brasileira, cuja letra compreende uma alegoria da conjuntura cultural de reformulação da realidade do Brasil e da própria MPB: “[...] Eu organizo o movimento/ Eu oriento o carnaval/ Eu 
inauguro o monumento no planalto central/ Do país/ Viva a bossa/ Viva a palhoça/ [...]/ Viva Iracema/ Viva Ipanema/ [...]/ Viva a banda/ Carmem Miranda-da-da-da [...]". Tempos depois, originado na periferia da cidade de Recife em 1991, o movimento Manguebeat unia elementos regionais-étnicos, como o maracatu, a ciranda e o xaxado, à música negra da periferia norte-americana, promovendo a diluição das fronteiras culturais e a ressignificação da tradição. Nesse sentido, a canção "Etnia” (1996) é exemplar quando aborda a miscigenação e aproxima manifestações culturais diferenciadas num "Maracatu psicodélico/ Capoeira da pesada/ Bumba meu rádio/ Birimbau elétrico":

Somos todos juntos uma miscigenação

E não podemos fugir da nossa Etnia

Todos juntos uma miscigenação

E não podemos fugir da nossa Etnia

Índios, brancos, negros e mestiços

Nada de errado em seus princípios

O seu e o meu são iguais

Corre nas veias sem parar

Costumes, é folclore, é tradição

Capoeira que rasga o chão

Samba que sai na favela acabada

É hip hop na minha embolada

A modernidade, marcada pela industrialização, pelo avanço econômico e pelas migrações, e a hipermodernidade, com sua velocidade midiática, caminhos virtuais e identidades múltiplas, converteram a cidade na experiência da mistura, na dinâmica do renovar da tradição concomitantemente ao surgimento de novos modelos tecnológicos, principalmente na América Latina. Sendo assim, os meios de comunicação foram primordiais para o movimento de aceleração da típica dinâmica híbrida local.

A canção pop brasileira surge carregada desses traços de cultura imersos num contexto capitalista de urgência pela reformulação dos anseios ideológicos em meio ao avanço da midiatização e tecnologização musical em âmbito global.

Nesse sentido, o conceito de "tradição" pode ser aplicado:

Tradição, aqui, é vista como algo dinâmico, aberto às leituras que o presente seleciona e sua busca deve ser encarada como uma tentativa de olhar para o passado com o intuito de recuperá-lo para o presente, tendo como impulso a necessidade de esclarecer os sentidos do processo, estabelecendo conexões, diferenças e possibilidades habitualmente escamoteadas. A compreensão da tradição funciona assim, como um elemento formador contemporâneo, apresentando 
versões do passado deliberadamente criadas para estabelecer conexões com o presente, atribuindo-lhes sentidos. (PEREIRA, 2007, p. 153)

Ela é, portanto, uma espécie de saber acumulado que as culturas possuem de si mesmas e que utilizam nas linguagens, ademais das expressões artísticas como a poesia e a canção.

Um movimento cultural/musical é cercado por uma complexa dinâmica interna em que se descartam tanto os aspectos considerados "marginais", quanto a constituição de elementos hegemônicos das formas dominantes. A canção "Inclassificáveis" (1996), de Arnaldo Antunes, faz referência ao tema da miscigenação nacional a partir da pergunta "que preto, que branco, que índio o quê?", cujos elementos se misturam na segunda estrofe numa dinâmica que reforça o sentido da letra. Por sua vez, a resposta contém uma variedade de palavras que retratam as etnias matrizes da nacionalidade brasileira e sua pluralidade evidenciada pelo coletivo "somos", além do registro de novas combinações - "crilouros guaranisseis e judárabes". Essas transformações estabelecidas pelo texto resultam no reconhecimento: "somos o que somos/ inclassificáveis".

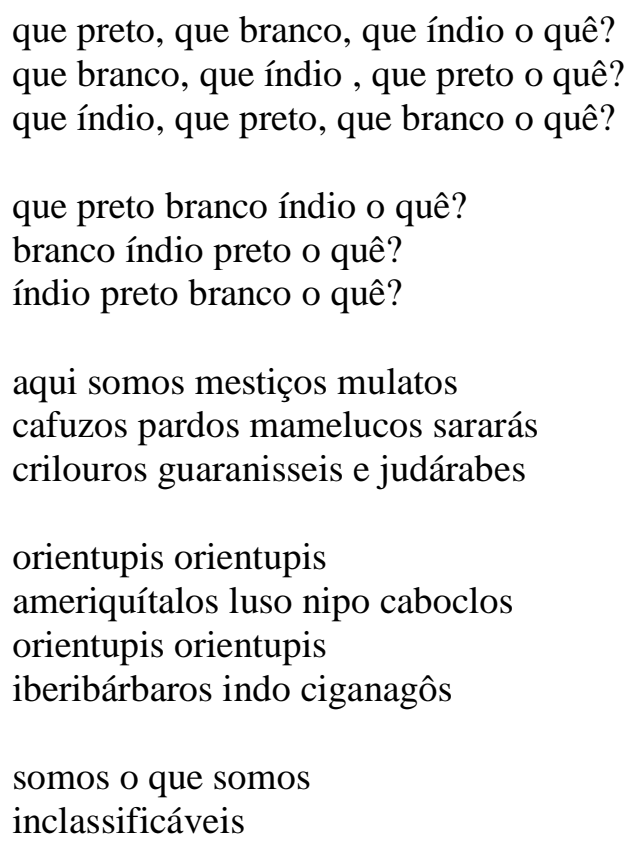

De acordo com Cyntrão (2009, p. 49), “o mundo desenhado por Caetano na década de 70, e por Science e Antunes, a partir de 90, apresenta uma consciente hibridação [...]. Os poemas contemporâneos hoje convivem num espaço de discursos diferenciados e plurais. Um espaço ideologicamente inclusivo, felizmente”. 
Pretende-se nessa pesquisa uma análise para além da "sociologia da cultura" nos moldes de Williams (1992), que considere uma perspectiva histórica com base na cultura enquanto prática cotidiana. Tendo como espaço o contexto hipermoderno serão levados em consideração os aspectos intrínsecos da vida em sociedade: economia, política, trabalho, relacionamentos, urbanização, tecnologia, mídia, consumo etc. Para isso, é necessário perfazer a história da canção e das subjetividades de modo a entender como essa arte é representada e interpretada no cotidiano dos sujeitos "hiper". Busca-se ressaltar uma cultura compreendida enquanto "processo social total", onde pensamento e viver cotidianos são intrínsecos.

\subsection{A Música Popular Brasileira: mercado, mídia e consumo}

Sempre narrando fatos marcantes da existência do sujeito a canção popular sofreu variadas transformações de cunho social, cultural, estético e técnico. Hoje, sob influência ainda mais forte das mídias, aparece mergulhada num contexto de intercomunicação instantânea em nível global. Assim, a chamada cultura global busca, no plano econômico, estratégias que permitam converter um produto cultural em mercadoria, valorizando o poder de venda, muitas vezes, em detrimento da competência artística.

No século XX, acompanhou-se o desenvolvimento dos sinais acústicos marcados pela evolução das técnicas de emissão sonora. No caso da canção, sobretudo, graças ao conjunto rádio-disco. Tudo isso torna possível o surgimento de um novo tipo de canção: a "canção das mídias", composta de tal modo a ser ouvida em todo o planeta.

Inserindo "conhecimento" em sua produção e assumindo uma função que estava abandonada na sociedade em mudança, a música popular brasileira procurou atingir, por meio do "mass media", aquela faixa da sociedade distante do processo tradicional de socialização imerso no conteúdo dos livros.

Seguindo essa tendência, as canções, por meio das letras, disseminam temas e problemáticas, tendo papel fundamental na institucionalização de "conhecimentos" vitais para o "sujeito comum", frente às constantes mutações da realidade. Como verdadeiros "trabalhadores intelectuais", dominam técnicas culturais diretivas que dão às letras um "significado 2", uma mensagem latente capaz de fornecer maneiras de elucidar o contexto em que estamos inseridos. 
Difusores de itens culturais e informações, o rádio e a televisão são um caso a parte quando se trata dos meios de comunicação de massas. Ao passo que as informações podem ser definidas como fatos novos de caráter provisório; a cultura permanece, povoando a mente dos receptores.

Pode-se falar da cultura a nível individual, o mobiliário do cérebro de cada pessoa, mas também abordamos a cultura de uma civilização qualquer por meio de uma imagem global, por meio de um estilo único presente na sua memória social.

Nessa civilização, o rádio e a televisão são as formas mais completas e influentes de comunicação de massa, fornecendo aos sujeitos fragmentos de conhecimento, o material para a possível construção de novas criações intelectuais. Observa-se a importância do papel desempenhado pela restrita camada da sociedade que possui a aptidão criadora para manter vivos esses fragmentos, sejam eles de natureza científica, política ou artística. Esses indivíduos especializados representam o diferencial da cultura em cada momento histórico, o desenvolvimento da experiência intelectual de conhecimentos disseminados pela sociedade.

A influência do mercado e sua enorme dimensão apoiada em recursos técnicos e comerciais poderosos resultam em importante transformação da função e do teor da canção popular. Concretiza-se o poder de intervenção sobre a canção, agora direcionada por diversos agentes mercadológicos, inclusive o público.

Os órgãos de difusão, por meio de suas produções artísticas, musicais e propagação de notícias, fabricam mensagens que alimentam o meio social, de modo que alguns indivíduos tomarão tais mensagens como ponto de partida para a criação de novas ideias, revoluções, invenções, obras de artes e letras de música. Graças à difusão permanente, a canção é um dos mais influentes produtos da indústria cultural que está presente em todos os meios, classes e idades da sociedade.

A história da canção midiática também é marcada pela formação do repertório individual do intérprete, já que estes desenvolvem uma performance própria, transformando-se até mesmo em "modelos" ou ícones do panorama musical de uma época. É o caso de Chico Buarque - sua forma de expressão, marcada pela singular impostação da voz, pelo olhar, pelos gestos, torna-o prontamente identificável pelo público: 
A voz do cantor amolda fisicamente o que ela diz; mais ainda, quando canta, poderíamos dizer que ele produz, em sua própria vocalidade, na sua espessura física, os ritmos do seu canto, o fato que ela conta. Ela o expande no seu próprio espaço-tempo vocal. De modo que a força do discurso e o talento cantor fundam, definitivamente, a realidade do que é dito. (ZUMTHOR, 2005, p. 101)

Nesse sentido, "a canção das mídias vai se compondo, assim, dentro desse mosaico-prosaico de possibilidades técnicas e estéticas, incluindo fragmentos de repertório da música erudita, dissociada de seu contexto integral, bem como a adaptação e apropriação de temas oriundos do repertório oral (folclórico) de acordo com o padrão estético do momento" (VALENTE, 2007, p. 85).

Se, por um lado, nos anos 1920-1930, as músicas populares traduziam uma determinada cultura local, por outro lado, atualmente, esse quadro não se repete visto que elas encontram-se "misturadas" (VALENTE, 2007, p. 92). Por isso, deve-se rever o conceito de "mestiçagem", que trata dos cruzamentos e trocas que ocorreram no âmbito da música, mas que foram acelerados e generalizados em escala mundial nesses tempos de mídia e globalização:

É, contrariamente à mistura e mixagem, um pensamento da tensão, ou seja, um pensamento essencialmente temporal, que evolui através das línguas, dos gêneros, das culturas, dos continentes, das épocas, da história e das histórias de vida. Não é o pensamento da fonte, da matriz, nem a filiação simples, mas um pensamento da multiplicidade nascida do encontro. É um pensamento voltado a um horizonte imprevisível, que permite dar toda dignidade ao futuro. (LAPLANTINE; NOUSS, 2002, p. 84)

Apoiada em algumas dessas premissas, as músicas nascidas na hipermodernidade seguem a tendência de resgatar as tradições esquecidas, apoiadas no encurtamento da distância entre as culturas, graças à rede mundial de computadores. Dando encadeamento às consequências do avanço dos meios de produção e divulgação em rede, observa-se a sistemática supressão das hierarquias entre o erudito e o popular. Essa comum distinção torna-se ultrapassada em meio à veloz e contínua mistura de informações e conceitos, apesar de ainda praticada por diversos críticos e músicos. Pode-se falar ainda numa maior complexidade do signo musical ligado à sua produção, condições de difusão, fixação e recepção. As fronteiras entre os domínios do clássico e do popular mostram-se, a cada dia, mais instáveis e efêmeras. De qualquer modo, a canção erudita, embora menos numerosa, não desapareceu em meio ao amplo repertório 
de músicas disponíveis atualmente, demonstrando que a globalização pode não atingir características regionais específicas ou pessoais.

Quanto à globalização, transita o juízo de que esta "poderia promover uma tendência à indiferença, ao embotamento dos sentidos - ao enfraquecimento da sensibilidade artística" (VALENTE, 2007, p. 95). Apesar da forte influência de uma homogeneização, típica do mundo globalizado, a cultura pop e suas canções desenvolvidas para o lucro do mercado cultural ainda podem imprimir traços exclusivos no panorama sonoro. De origem local, o tango, o samba e o jazz mostram que o natural processo de transculturação sofrido por eles não ameaçou a continuidade de suas culturas de origem. Na verdade o fenômeno é outro, as culturas tendem a sorver o que não lhes pertence, ou seja, dados novos são impressos sobre os traços de origem. Esse comportamento norteia as convenções que regulam a sensibilidade, possibilitando o desfrutar dos textos artísticos.

De acordo com Zumthor (1997), a tradição poética, responsável por orientar as convenções que regulam a sensibilidade poética, segue um processo contínuo onde novos dados são impressos sobre os traços anteriores. É a partir dos valores sobre os quais se sustenta, e por meio da memória, que uma comunidade adere a determinadas formas de pensamento, de discurso, de sensibilidade e de ação. Sendo a cultura informação, codificação, transmissão e memória, a sociedade, por sua vez, tende a rechaçar os elementos indesejáveis: o processo de memória envolve não apenas a permanência, mas também esquecimento. As canções midiáticas, em tempos de mercado de consumo, também se encaixam nesse cenário.

De fato, uma tradição poética é constantemente atualizada por elementos novos impressos sobre traços precedentes. Esta tradição poética estabelece as convenções que orientam a sensibilidade poética e possibilitam a fruição dos textos artísticos. Por meio da memória uma comunidade adere a determinadas formas de pensamento, de comportamentos, de sensibilidade e de discursos, de acordo com os valores sobre os quais ela está alicerçada.

A grande reviravolta provocada pelos novos meios de comunicação está relacionada ao fato que esses conseguiram se aproximar das necessidades da grande população que não lê livros e que sempre foi desconsiderada pela cultura tradicional, enquanto modo de expressão do imaginário. Surge, então, uma nova ordem social onde todos podem participar, não mais uma ordem social idealizada na tradição cultural. 
Da mesma forma, a ruptura entre a mídia tradicional e a revolução decorrente da criação do ciberespaço e da cibercultura são relevantes. Conforme o filósofo francês da cultura virtual contemporânea, Pierre Lévy (2001, p.29): “Um aparelho de televisão é um receptor passivo, uma extremidade da rede, uma periferia. Um computador é um instrumento de intercâmbio, de produção e de armazenamento de informações”. E prossegue: "Desde que canalize e entrelace um grande número de fluxos, torna-se um centro virtual, um instrumento de poder".

A transformação das sociedades atuais tem como agente fundamental as técnicas e seus mais diversos formatos e utilidades, além de todas as consequências que as mesmas têm sobre o nosso cotidiano e várias atividades. Além dessas alterações rotineiras, estas técnicas carregam implicações menos perceptíveis mais fundamentais na vida do sujeito hipermoderno: transformações na maneira de conhecer o mundo, no jeito de interpretar este conhecimento e na comunicação destas representações por meio da linguagem.

Seguindo suas reflexões sobre as transformações sociais em meio ao espaço digital, tão necessárias ao estudo acerca do papel da mídia e a influência sobre a canção, Lévy (2001, p. 51-59) afirma:

O ciberespaço será o epicentro do mercado, o foco da criação e da aquisição dos conhecimentos, o principal meio da comunicação e da vida social. A Internet representa simplesmente o estágio de união da humanidade que sucede à cidade física. [...] $\mathrm{O}$ movimento de unificação intelectual, cultural e espiritual da humanidade seria incompreensível, incompleto, incoerente e muito simplesmente impossível se não fosse duplicado, acompanhado, apoiado pelo movimento de unificação mundial do mercado capitalista e pelo crescimento de um imenso tecnocosmo interconectado, interdependente e planetário que encontrou no ciberespaço o seu coroamento provisório e o seu principal agente.

Uma das consequências desse processo de institucionalização do conhecimento, diz respeito ao entendimento do mundo "real" e "imaginário": enquanto que o primeiro começa a ser entendido como "ilusório" exatamente por ser construído baseado na realidade criada pelo homem, o segundo, construído pelo "mass media", torna-se cada vez mais real através da visão do público. Vemos como resultado dessa crescente mistura entre fatos reais e imaginários, o desaparecimento do limite que separa "ilusão" e "realidade". Tem origem uma infinita gama de entendimentos do que seja "realidade" e "ilusão". Em meio à grande pluralidade presencia-se a significativa perda de pontos de referência que sejam comuns a todos indivíduos. Tudo isso dará à música popular, por 
meio da cultura de massas, um lugar de norteador da institucionalização do conhecimento da condição social em que vivemos.

Essa relação entre realidade e ilusão é abordada de maneira exemplar por Chico Buarque de Hollanda na simbologia da "tela" em meio à exposição midiática do mundo globalizado da canção "Nina”, conforme será apreciado no capítulo quatro.

Há tempos que a canção popular solidificou seu lugar de fator de transformação de valores e comportamentos. Ela foi responsável por traduzir a primeira geração brasileira formada no interior da recente organização tecnológica de comunicação.

Refletindo sobre o avanço nos estudos ligados à análise musical, observa-se a ampliação do seu campo de análise que ultrapassa os estudos etnomusicológicos, alcançando reflexões acerca da música popular de massas, ou seja, a música midiática. Nesse sentido, vale considerar os estudos antropológicos da música midiática, ou seja, uma abordagem cultural do tema fundamentada nos caminhos oferecidos pela Antropologia, pois esta área do conhecimento detém grande importância para o estudo da música investigando as linguagens estéticas e suas relações com os sistemas culturais. Ela se propõe a compreender as fronteiras culturais, refletindo sobre o que é comunicado, quais os limites da manipulação dos símbolos, qual o nível de impermeabilidade às mensagens e em como se articulam e rearticulam as culturas locais frente às globais, dedicando-se a reconsiderar hierarquias e classificações de níveis culturais.

Sendo assim, a Antropologia contribui para o entendimento das sociedades contemporâneas e suas dinâmicas culturais, sociais, estéticas e musicais, levando em consideração a presença do hibridismo cultural em um momento em que compreender os diferentes movimentos comunicacionais da atualidade revela-se de grande importância, visto que a mídia assume cada vez mais a tarefa de definir identidades, intervindo nas ações da cultura contemporânea. Com a globalização e o surgimento das mídias, antigos ideais sobre fronteiras e identidades culturais foram redefinidos com base nas dicotomias contemporâneas da tradição versus modernidade, local versus global, etc. A canção contemporânea exerce o importante papel de combinar esses elementos que, em constante movimento, se unem e se transformam.

Observa-se que esse recente campo de estudo da Antropologia vem ao encontro dos interesses dessa pesquisa no que diz respeito à articulação de diferentes áreas da pesquisa e do conhecimento com o intuito de estudar as culturas musicais urbanas em 
meio ao contexto hipermoderno influenciado pelo mercado de bens de consumo. Considerando que música, comunicação, cultura e cotidiano estão intimamente interligados, e que, por isso, são essenciais para o entendimento das sociedades midiáticas e tecnológicas atuais, busca-se compreender as complexas relações entre eles por meio da repercussão dos signos musicais na sociedade, enquanto modelo de consumo e representação cultural.

Compreendendo a canção enquanto manifestação cultural, pretende-se tomar como eixo conceitual uma noção de cultura descolada de sua tradição elitista, considerando como eixo de análise as práticas cotidianas e seus múltiplos papéis, além da capacidade de improvisar e subverter os modelos tradicionalmente impostos. Por isso, esse estudo surge da necessidade primeira de refletir sobre o vínculo entre cultura contemporânea e sociedade, numa relação em que o cotidiano deve ser o principal foco de interpretação e a cultura assume características diversas concebidas no cotidiano, resultado de variadas influências tanto locais como globais. Mais ainda:

[...] este conceito de cultura relaciona produção, distribuição, recepção de bens culturais e práticas econômicas, garantindo aderência às condições materiais e aos aspectos simbólicos da vida de uma dada sociedade num momento histórico específico. Desta forma, a cultura mantém com as questões político-econômicas uma relação de dupla mão no que tange às influências, em que os âmbitos políticos, econômicos e culturais competem entre si e se relacionam em conflito numa sociedade complexa. (PEREIRA, 2007, p. 152)

Conforme Raymond Williams (1992), para se refletir sobre formas artísticas e culturais é preciso desenvolver uma análise que relacione as instituições culturais, as formas de produção, os procedimentos de reprodução da cultura e sua organização, ademais da linguagem artística. Assim, é preciso estabelecer-se uma "sociologia da cultura".

As origens históricas de uma forma artística, enquanto linguagem e cultura, necessitam ser investigadas como modelos variáveis no tempo, imersas numa complexa teia de hegemonias, ideais, resistências, e não como conceito fechado, inflexível e supra-histórico.

A popularidade de uma música também está ligada à sua natureza melódica e rítmica. As palavras, por carregarem variados valores e concepções, igualmente intervém na popularidade de determinada canção, contribuindo para o exame do caráter social dos signos, tão preponderante para o estudo proposto da cultura hipermoderna. 
No entanto, essa pesquisa tem como opção teórica o trabalho de análise que considera a letra como foco.

A intenção é examinar como a situação social vivida é manifestada nas composições estudadas, demonstrando seu caráter enquanto técnica de difusão de valores e padrões de comportamento típicos do processo. Tal transmissão não aconteceria sem a disponibilidade dos meios de comunicação e sem o trabalho intelectual dos compositores, cada vez mais atuantes no processo. 


\section{O LUGAR HIPERMODERNO: O PARADOXO DA CULTURA MUNDO E AS TRÊS ONDAS DE DESCONTINUIDADE}

Antes de discutir o conceito de hipermodernidade e suas características presentes na recente produção musical de Chico Buarque, faz-se necessário apresentar o termo pós-modernidade para o entendimento posterior acerca desse conceito desenvolvido por Gilles Lipovetsky.

Muitos teóricos dedicam-se ao trabalho de perfazer o percurso histórico das origens do termo pós-modernidade, de modo que considera-se o texto As origens da pós-modernidade, de Perry Anderson (1999), particularmente esclarecedor por apresentar um histórico do conceito a partir de variadas óticas até sua solidificação na década de 1970, principalmente, baseando-se num enfoque voltado à estética e à teoria literária, assuntos de grande importância para a presente tese.

O pós-modernismo, definido como movimento, consistia numa "mistura libertadora do novo e do velho, do elevado e do vulgar", tudo isso alicerçado em recursos simbólicos que tinham como meta contemplar a necessidade contemporânea por uma nova espiritualidade. Nesse novo panorama, a informação é mais preciosa do que a produção, de modo que antigas polaridades como esquerda versus direita, capitalismo versus operariado deixam de ter sentido (ANDERSON, 1999, p. 30).

A condição pós-moderna foi a primeira obra filosófica a discutir o conceito de pós-moderno, sendo publicada por Jean-François Lyotard em 1979. Giddens (1991, p. 12), no seu As consequências da modernidade, avalia Lyotard como o teórico responsável pela popularização do conceito de pós-modernidade por tratar o termo enquanto "um deslocamento das tentativas de fundamentar a epistemologia, e da fé no progresso planejado humanamente". Ainda de acordo com Giddens, a condição da pósmodernidade tinha como característica central o enfraquecimento do poder das "grandes narrativas" responsáveis por inserir o indivíduo num processo histórico com um passado estabelecido e um futuro profetizado.

A descredibilidade das grandes narrativas, uma das mais importantes características da condição pós-moderna, é reconhecida como uma mutação completa na conjuntura humana. Entre as grandes narrativas extintas, Lyotard (1989) ressalta a redenção cristã, o progresso iluminista e a unidade romântica. Se por um lado a ciência caminha a serviço do poder, por outro as relações humanas tendem para o contrato 
temporário nas diversas áreas da vida, seja política, emocional ou sexual. Desse modo, os vínculos tornam-se mais econômicos e flexíveis que os da modernidade. Anderson (1999, p. 34-35) vai além, abordando a influência da produção cultural nas relações afetivas dos sujeitos:

A única coisa que poderia destruir o capitalismo era o "desvio do desejo" entre os jovens, em todo o mundo, de um investimento da libido no sistema para estilos de conduta "cujo único guia é a intensidade afetiva e a multiplicação do poder da libido". O papel dos artistas de vanguarda [...] era explodir os obstáculos à manifestação desse desejo lançando as formas da realidade estabelecida às chamas.

O avanço da ideologia de direita, novo perfil traçado nos anos de 1980, culminou com o colapso do bloco soviético e fez nascer a maior das narrativas que dominou o mundo: "a vitória global do mercado" reforçada pela promessa única de liberdade e prosperidade (ANDERSON, 1999, p. 39).

De acordo com Anderson (1999, p.42), Lyotard já previa esse quadro ao escrever que "a emancipação não é mais a tarefa de conquistar e impor a liberdade de fora", mas, na verdade, trata-se de "um ideal que o próprio sistema se esforça em realizar na maioria das áreas que cobre, como o trabalho, os impostos, o mercado, a família, o sexo, a raça, a escola, a cultura, a comunicação [...], isto é emancipação palpável”.

Outras alterações sociais também eram apontadas por Jameson que considerava a forte influência da propaganda e da mídia para dissimular a exploração e a injustiça social, além da nítida oposição entre a vida pública e a privada, responsáveis pelo desenvolvimento de uma sociedade sem precedentes:

Em termos psicológicos podemos dizer que, como economia de serviços, estamos doravante tão afastados das realidades da produção e do trabalho que habitamos um mundo onírico de estímulos artificiais e experiência via TV: nunca, em nenhuma civilização anterior, as grandes preocupações metafísicas, as questões fundamentais do ser e do significado da vida pareceram tão absolutamente remotas e sem sentido. (ANDERSON, 1999, p. 63)

Jameson (1997), ao agregar o período modernista ao capitalismo monopolista e o pós-modernismo ao capitalismo tardio - localizado após a segunda grande guerra, usa este último para apresentar a lógica da dominação cultural, que conduz a transformação do campo cultural na sociedade contemporânea. Assim, o pós-modernismo teria como alicerce a influência do capitalismo multinacional contemporâneo difundido por uma "rede global descentralizada", cujo resultado é o vitorioso avanço da cultura em todo 
campo social, "a ponto de se poder dizer que tudo em nossa vida social [...] tornou-se 'cultural"' (EAGLEATON, 1998, p. 26).

Considera-se, então, o modernismo como o processo comprometedor da estabilidade que caracteriza a modernidade, observando que o conceito de "moderno" se incorpora ao de "contemporâneo" responsável por justificar e legitimar a produção artística de vanguarda até a década de 1970. Justamente essas vanguardas históricas que atuavam por meio da "supressão dos limites do estético, em direção a um alcance metafísico, ou histórico-político da obra" (VATTIMO, 1996, p. 43). Como evolução desse processo, o pós-modernismo é impulsionado pelo surgimento de inovadoras tecnologias que alteram a relação entre arte e sociedade. A guinada cultural (1982), de Fredric Jameson, torna-se texto fundamental nos estudos do pós-moderno a partir de "cinco lances decisivos" numa definição completa sobre o termo (ANDERSON, 1999, p. 66):

1. A pós-modernidade cultural se escora em novos modos de produção, em uma nova "lógica do capital".

2. A cultura é a segunda natureza, já que o modernismo destruiu a natureza primitiva; a destruição do passado minou a objetividade e instaurou a subjetividade. A publicidade e as mídias eletrônicas desempenham papel ativo nesse processo.

3. Abrangência de todas as manifestações culturais; acompanhada pelo cruzamento interdisciplinar, confluindo em uma "teoria".

4. Entrada de novos povos no "palco global"; segundo Anderson, o Terceiro Mundo nivela por baixo a cultura, encerrando a era das "obras-primas do Modernismo".

5. A tentativa de evitar uma "moralização" do pós-modernismo, sem a arcaica classificação entre bem e mal. (SALLES, 2005, p. 21)

As projeções entusiásticas do progresso histórico foram sucedidas por horizontes mais breves, por um tempo dominado pelo precário e pelo efêmero. Em meio à derrocada das construções voluntaristas do futuro e o triunfo dos ideais consumistas centrados na vida presente, edifica-se o período pós-moderno: um novo tempo caracterizado pela primazia do aqui-agora.

Ao mesmo tempo, a expressão "pós-moderno" era vaga. Isso porque era notório que uma modernidade de novo gênero surgia, e não uma simples superação daquela anterior. Inicialmente, o conceito de pós-moderno sugeria o novo, uma descompressão do social; hoje, entretanto, o termo torna-se obsoleto frente a um tempo que volta a endurecer-se em meio à crises de identidades e angústias existenciais. 
Enquanto filósofo dos paradoxos do mundo contemporâneo, Gilles Lipovetsky afirma que não estamos na pós-modernidade, mas na hipermodernidade. O termo pósmodernidade seria, segundo ele, ambíguo visto que difundia uma ideia de superação da modernidade quando, de fato, a modernidade não acabou, mas atingiu o seu extremo: o “hiper”. O máximo e o mínimo ao mesmo tempo em meio à aceleração total. Em plena era da mídia, vemos a tecnologia agir sob todos os âmbitos da vida. O público e o privado se confundem, de modo que é preciso estar sempre conectado. Vemos, por exemplo, o fenômeno dos blogs e redes sociais onde expomos para desconhecidos o que antes era reservado à nossa família e amigos. O resultado disso é que, na medida que cresce a obsessão pela interatividade, aumentam as cobranças sobre si mesmo. É preciso ser bem-sucedido, dar um sentido satisfatório ao próprio destino. Nunca houve tanta liberdade para expressar seus desejos e nunca estivemos tão presos aos padrões impostos pela sociedade hipermoderna que cobra novas posturas. Sendo assim, a liberdade acaba tendo um alto preço: a frustração.

A decepção torna-se diretamente proporcional ao desejo na medida em que o sujeito hipermoderno, fruto do excesso de modernidade, cria suas utopias: vida simples e sofisticada, corpo perfeito, alimentação natural, interatividade total, politicamente correto, realização pessoal, etc. Observamos:

[...] o apelo ao pluralismo metodológico, inclinando-o à ambiguidade dos discursos construídos sobre o mundo. O saber se reinterioriza, graças à anulação dos "valores de uso", ao retorno do sujeito, ao triunfo da individualização sobre a idealização, do deslize sobre a ruptura. (ZUMTHOR, 2007, p. 96)

Reconhecido como um dos mais conceituados estudiosos dos paradoxos da sociedade contemporânea ou hipermoderna, como ele próprio denominou, Lipovetsky analisa nossa sociedade, que vive concomitantemente a liberdade social e a submissão frente o consumismo, o desfrutar dos prazeres proporcionados pela tecnologia e a decepção diante da busca incansável pela felicidade.

Eis os paradoxos "hiper": desejamos compromisso e independência ao mesmo tempo; se por um lado nossa principal motivação é a satisfação pessoal, por outro não conseguimos afastar o fantasma da decepção. Um dos maiores fatores da decepção nos dias de hoje é o enfraquecimento das religiões tradicionais, e aí está novamente o paradoxo: se de um lado cresce a descrença, e, consequentemente, os referenciais cuja 
escassez deixa o sujeito mais vulnerável ao desamparo e a frustração, por outro aumenta vertiginosamente o interesse no esoterismo, em novas seitas e religiões.

O filósofo prefere destacar o novo papel adotado pelo indivíduo-protagonista social, assim como o poder de disseminação do processo de autonomia subjetiva, marcado pelos ideais de consumo, lazer e bem-estar de massa. Contrariando o clima de desconfiança predominante, o autor busca evidenciar o fenômeno de emancipação do indivíduo em detrimento às imposições vigentes que caracterizam nossa sociedade como um organismo programado pelo capitalismo burocrático. Algo que se estabeleceu em meio à liberação sexual, à ruptura com as obrigações morais, à falta do compromisso ideológico, no modelo de vida à la carte. Vale lembrar que tal revolução de teor individualizante e narcisista não foi somente positiva. Apesar do otimismo trazido pela democracia liberal, tal evento trouxe menos vantagens para o sujeito do que o esperado:

O hedonismo foi despojado de sua aura triunfal: passamos de um ambiente de euforia progressista para uma atmosfera de ansiedade. Antes, havia a sensação de que a existência se tornara um tanto menos pesada; hoje, "tudo se contrai", endurecendo de novo. Este é o "paradoxo da felicidade": uma atmosfera de entretenimento e distensão contínuos, de bem-estar consolidado, coexiste com a intensificação dos obstáculos para se viver e o aprofundamento do mal-estar subjetivo. (LIPOVETSKY, 2007, p. 4)

Nesse contexto, vê-se o poder de uma cultura sem fronteiras com o objetivo de edificar uma sociedade global de consumidores, o que os autores citados denominam de "cultura-mundo". Será observado no capítulo quatro de forma sistemática como esses eixos são representados nas canções selecionadas. Entre elas, citamos “Querido diário", faixa de abertura do álbum Chico. Por meio de uma toada caipira, observa-se um sujeito que, através de uma narrativa do seu cotidiano, reflete sobre a solidão, religiosidade e amor em meio ao caos dos novos tempos "hiper". "Querido diário" é a canção representativa dessa pesquisa que compõe, inclusive, o título da presente tese por meio da imagem-chave da "cidade toda em contramão". Ela dedica-se à estabelecer uma cartografia sócio-histórica deste momento de fraturas, levando em consideração o espaço do contemporâneo nacional representado por Chico Buarque com o alerta: "Hoje a cidade acordou na contramão [...] homens com raiva [...]".

As narrativas de suas canções apresentam um modelo de indivíduo cuja identidade está vinculada tanto à intensidade e à urgência de sua vivência passional quanto à consciência existencial dessa mesma experiência. Por isso, sua lírica restaura 
elementos da tradição, incorporando a eles padrões culturais da atualidade, numa dinâmica discursiva que restabelece o trânsito em mão dupla.

A cidade, em um contexto hipermoderno, é vista como principal ator social, pois ela está no centro do processo de urbanização e da questão do consumo.

Por sua vez, o sujeito se sente perplexo e desorientado, visto que ainda não desvendou o modo de funcionamento das novas cidades, mas, paradoxalmente (o que remete tanto à 'mão' quanto à 'contramão', no trânsito de ideias e ideais), sente-se aprisionados em sua lógica.

Chico Buarque é um desses sujeitos: "Todas as grandes cidades pioraram. Não sou saudosista. Não tenho saudades do Rio. Tenho boas lembranças. Não tenho saudades de mim. Tenho boas lembranças. Hoje [o Rio] é uma cidade mais violenta, mais deteriorada". O artista também criticou a violência nas grandes cidades, reflexo de toda angústia e pressão social:

O sujeito aqui corre risco de ser atropelado mesmo na faixa da segurança. Ficam falando em violência e violência, mas é violência também quem dirige um carro e avança o sinal. Outro dia estava lá andando, atravessando na faixa, o sinal aberto para mim, o cara quase me atropela. Podia ter quebrado a perna ou ter morrido. E o cara tinha um adesivo: "Basta! Basta de violência". Violência também é isso.

A hipercidade é assim uma encruzilhada infinitamente complexa entre a lógica da produção/destruição do espaço urbano, tão fundamental ao ideal da modernidade e, ao mesmo tempo, uma nova lógica fundamentada num hiperespaço imaginário em constante movimento, que propõe e controla significados e práticas urbanas.

Assim, o movimento das cidades torna-se o mesmo dos ciberespaços, é o que afirma Lévy (2001, p.51): “As cidades existem necessariamente ao mesmo tempo e no mesmo lugar: mercados, centros de intercâmbios de informações e de desenvolvimento da cultura, espaços de sociabilidade. [...] Os mundos virtuais interativos, mais ou menos lúdicos, serão as novas obras de arte, os cinemas, os teatros e as óperas do século XXI".

Ao discutir as relações existentes entre o universo poético e esse hiperespaço imaginário, observa-se que o fenômeno da imaginação poética envolve uma variedade de simbolizações nas imagens, como explica a obra $A$ poética do espaço, de Gaston Bachelard, que propõe uma filosofia da poesia que se distancia do racionalismo filosófico, considerando uma filosofia da poesia que aparece ligada à "essencial novidade psíquica do poema" (1974, p. 341). Sendo assim, esta filosofia não considera o fazer poético relacionado ao passado, mas vinculado à “explosão de uma imagem”, 
capaz de repercutir profundamente os ecos do passado. $\mathrm{O}$ ato poético está mais ligado ao nível ontológico do que a uma racionalidade pré-concebida.

Uma fenomenologia da imaginação surge, então, como método de investigação de análise das imagens poéticas, visto que “estuda o fenômeno da imagem poética no momento em que ela emerge na consciência como um produto direto do coração, da alma, do ser do homem tomado na sua atualidade" (BACHELARD, 1974, p. 342). Bachelard adota esse método considerando o pressuposto de que a fenomenologia observa a imagem a partir da consciência do indivíduo e da sua repercussão no sujeitoouvinte-leitor.

Já as primeiras noções de cultura-mundo são remotas. Elas se aproximam de um conceito ético e liberal, de um humanismo universal que descarta a noção de que existam povos inferiores, entendendo o amor pela humanidade como superior ao amor pela cidade. Hoje vive-se a segunda era da cultura-mundo, do mundo sem fronteiras dos capitais e das multinacionais, do ciberespaço e do consumismo. Ligada à realidade hipermoderna, onde a economia mundial se comporta de acordo com um modelo exclusivo de normas, valores e objetivos, a cultura se impõe, trazendo a extinção da heterogeneidade tradicional e a universalização da cultura mercantil.

A cultura-mundo dissemina-se por todos âmbitos da vida social, dos modelos de existência, de grande parte das atividades humanas. Com ela, desenvolveram-se o cultivo da tecnociência, do mercado, das mídias, do individualismo, do consumo e, em consequência disso, novas problemáticas atravessam temas mundiais como a ecologia, a crise econômica, o terrorismo, além de questões existenciais ligadas à identidade, às ideologias, aos distúrbios da personalidade. O mundo se torna cultura, a cultura se torna mundo: nasce uma cultura-mundo em meio à angústia e dúvidas sobre si mesma.

Os princípios que constituíram a era moderna, agora radicalizados e levados ao extremo, dão origem à adequadamente denominada dinâmica hiper-moderna. O mesmo processo que edifica o hipercapitalismo globalizado e individualista, atinge o domínio da cultura. A cultura, que caracteriza os tempos hipermodernos, se define pelo fim da separação entre cultura e economia, pelo elevado desenvolvimento da esfera cultural e pela sua influência na ordem mercantil: podemos chamá-la, assim, de uma hipercultura, de uma "cultura-mundo". Fala-se, inclusive, em "capitalismo cultural", tamanha a expansão desse novo setor econômico que deixa para traz todo um legado de normas sociais, a cultura em seu sentido antropológico, e a representatividade da alta cultura. 
De fato, a cultura-mundo institui o sistema econômico-cultural do hipercapitalismo global de forma que o que é mercantil tende a ganhar status de obra cultural.

Assim como a arte passa a integrar o sistema mercantil, a cultura penetra o espaço comercial no momento em que a arte é reciclada pelo mercado, tornando-se parte da cultura-mundo. Em tempos de hipermodernidade cultural, a cultura converte-se no mundo das marcas e do consumo. Essa lógica da cultura-mundo vem de séculos de história, tendo assumido sua total dimensão no período recente desenhado ao longo do século XX.

O ideal de cultura enquanto instrumento de educar o homem e elevar o gênero humano, moldando-o do modo mais correto, é abandonado em nome de uma cultura de massa que cultiva o hedonismo individualista e o divertimento sem precedentes. Partem daí alguns dos questionamentos que fundamentam essa pesquisa: que sociedade está sendo formada? Que sujeito produz nessa civilização hipermoderna? Adiante será analisado como essas questões são abordadas nas letras das canções de Chico Buarque, visto que também o mundo da música foi alterado pelo avanço dos meios de reprodução e de propagação sonoras:

[...] o velho rolo cilíndrico do início deu lugar ao disco, que foi substituído pelo microssulco, antes que o CD viesse a tomar seu lugar. Do fonógrafo à aparelhagem hi-fi e, depois, ao walkman, a música, outra linguagem universal que transcende as línguas e as fronteiras, retoma por conta própria o sistema adotado pelo cinema: ídolos planetários (Presley, os Beatles...), difusão cada vez mais ampla, música-moda constantemente renovada, consumo ao mesmo tempo individualizado e de massa, graças, em particular, ao transistor, ao microssulco e, claro, à televisão. (LIPOVETSKY; SERROY, 2011, p. 74-75)

Tudo isso acompanha a evolução do próprio sujeito contemporâneo que se representa nas letras que cria. Em meio à variedade e ao excesso de informações, ele se pergunta como educar os indivíduos e formar espíritos livres.

Essencialmente imerso nos livros e nas produções do espírito, o domínio intelectual, nos tempos hipermodernos, se encontra ampliado às marcas, à moda, ao estilo, tornando-se uma criação, ou seja, um produto cultural. Essa queda no valor da cultura, nas áreas das humanidades, da literatura e da filosofia, é marcada pela perda da aura e da legitimidade da cultura nobre, além da exaltação ao capitalismo e ao hedonismo consumista, um processo já chamado por alguns estudiosos de "barbárie intelectual e estética”. 
A globalização gera a erosão das fronteiras e a compressão do espaço-tempo, mas não o fim das distâncias culturais. É preciso observar que quanto maior o acesso dos sujeitos à cultura-mundo, maior o sentimento de defesa das suas identidades culturais e linguísticas. O indivíduo hipermoderno, apesar de todos os apelos do contexto, não se satisfaz com os prazeres oriundos do consumismo; ainda deseja atuar, mostrar seu ponto de vista, participar da vida pública, sem demandar o sacrifício da vida privada e da liberdade de opinião subjetiva. A tendência ao narcisismo consumista e ao desengajamento político é crescente, mas o hiperindividualismo não é necessariamente o mesmo que total despolitização e desinteresse pela coisa pública.

Concretizada pelo hipercapitalismo de consumo, a cultura-mundo institui a importante ampliação dos espaços da comunicação, da informação, da midiatização: essa hipercultura difunde conhecimentos sobre o mundo por meio de imagens, filmes, músicas, programas televisivos, transformando os modelos de existência e comportamento. Ao impor a lógica de mercado, a mercantilização integral da cultura é acusada de padronizar pensamentos, desfazer laços sociais e manipular a opinião, corrompendo a democracia. Em plena cultura-mundo as velhas oposições da economia e do cotidiano, do mercado e da criação, do dinheiro e da arte diluíram-se, perderam a essência de seu fundamento e de sua realidade social. Estabelece-se uma revolução onde o cultural se dissolve num mundo material plenamente disposto em desenvolver bens de consumo ricos de estilo, identidade, moda que se disseminam por meio das marcas, do comércio global e dos velozes meios de comunicação. Ao passo que a arte se alinha com as regras do universo do mercado e da mídia, o capitalismo edifica uma cultura própria, ou seja, um princípio de estética, valores, objetivos e mitos.

Agora, a combinação entre o econômico e a dimensão do imaginário social é explícita, administrada e constituída dentro de um "sistema-mundo globalizado" (LIPOVETSKY; SERROY, 2011, p. 10-11).

Ainda segundo Lipovetsky e Serroy (2011, p. 11):

É assim que a cultura-mundo cobre um território muito mais vasto que o da "cultura cultivada", cara ao humanismo clássico. Além da cultura erudita e nobre, impõe-se a cultura ampliada do capitalismo, do individualismo e da tecnociência, uma cultura globalitária que estrutura de maneira radicalmente nova a relação do homem consigo e com o mundo. Uma cultura-mundo que não reflete o mundo, mas o constitui, o engendra, o modela, o faz evoluir, e isso de maneira planetária. 
Para que se estabelecesse uma melhor perspectiva desse novo regime de cultura apresentado, os autores propuseram um esquema de evolução histórica, a partir de três distintas eras das ligações da cultura com a sociedade, contextualizando a especificidade do momento atual ao longo da história, que também servirá de base teórica para a análise das canções selecionadas da obra de Chico Buarque, a partir dos critérios da intertranstextualidade, que representem as "três ondas de descontinuidade": do liberalismo artístico e cultural, até a sociedade hipermoderna.

Na primeira e mais longa era não é possível reconhecer a existência de uma esfera cultural autônoma; o que denominamos como "cultura" aparece de modo intrínseco às relações religiosas, políticas e parentais: “Em sua forma pura, 'selvagem' ou mítica, a cultura é a ordenação totalizante do mundo, aparece como um conjunto de classificações que asseguram a correspondência ou a 'conversibilidade' de todas as dimensões do universo [...]" (LIPOVETSKY; SERROY, 2011, p. 11-12). A fidelidade e a perpetuação das formas culturais ao longo das gerações são práticas que permeiam os costumes e os modos de pensar de forma coletiva, prescrevendo a reprodução exata dos modelos ancestrais, ou dos deuses, e não reconhecendo o princípio da iniciativa individual.

Coincidindo com o advento das democracias modernas, a segunda era é traduzida como o momento de revolução da cultura baseada nos preceitos de liberdade, igualdade e laicidade: “A modernidade acarretou em toda a parte uma dinâmica de secularização da cultura, seja ela política, jurídica, ética, cotidiana, literária ou artística, desenvolvendo-se cada um desses domínios segundo necessidades e uma dinâmica própria” (LIPOVETSKY; SERROY, 2011, p. 12). Contra a ultrapassada orientação dos particularismos, do domínio da Igreja, do culto às tradições e superstições, surgem sistemas autônomos em constante transformação pelo próprio homem que propagam o predomínio tecnológico sobre a natureza e o progresso sem limites.

A arte também sofre alterações graças ao antagonismo diante do velho panorama da hierarquia, da tradição e do imutável, provocado pela cultura dos modernos. Ela coloca-se em oposição aos valores dominantes, ao universo do mercado e do lucro por meio de uma natureza autônoma que se fundamenta em leis próprias e numa estética transgressora. Então, o domínio cultural orienta-se em torno de dois polos antagonistas: “de um lado a 'arte' comercial sujeita às preferências do público e orientada para o sucesso imediato; de outro, a arte pura e vanguardista recusando as formas de 
consagração burguesa e as leis do mundo econômico" (LIPOVETSKY; SERROY, 2011, p. 13).

Por último, os autores levantam a hipótese de uma terceira era que constitui o quadro cultural das sociedades contemporâneas há duas ou três décadas, no período de globalização. Nesse momento, as grandes utopias e a supervalorização do futuro perdem credibilidade, dando lugar ao largo investimento no presente por meio da reabilitação do passado, da remobilização das convenções religiosas e identitárias, das exigências particularistas e autênticas. A hipermodernidade é um novo modelo da cultura possível graças a essas transformações que remodelaram as identidades coletivas passadas pela lógica do individualismo e do consumismo. É esse o contexto que permeia as canções contemporâneas do álbum Chico. Em "Barafunda", encontra-se o sentimento de nostalgia e confusão entre o passado glorioso da tradição e o esquecimento trazido pela fugacidade dos novos tempos:

\footnotetext{
E salve a floresta, salve a poesia

E salve este samba

Antes que o esquecimento

Baixe seu manto, seu manto cinzento
}

A tendência de valorização do passado é vista no sucesso dos objetos antigos, nos produtos rotulados com um "legítimo" ou autêntico, que despertam a nostalgia. Na sociedade hipermoderna, a antiguidade e a nostalgia se converteram em especulação comerciais, ferramentas de um mercado que deseja mostrar que se orgulha da tradição. Os versos recobrem esses aspectos constitutivos da hipermodernidade. Eles estão, porém, ao mesmo tempo, inseridos nela, sujeitos às mesmas regras, alimentando-a.

Em "Nina" observa-se os relacionamentos à distância e suas nuances imersas nos mais variados recursos tecnológicos, mas que não dão conta de extinguir o caráter simbólico e representativo na vida dos sujeitos hipermodernos:

\footnotetext{
Nina diz que se quiser eu posso ver na tela A cidade, o bairro, a chaminé da casa dela Posso imaginar por dentro a casa A roupa que ela usa, as mechas, a tiara Posso até adivinhar a cara que ela faz Quando me escreve
}

Uma modernidade dividida e limitada deu lugar a uma modernidade consumada. Hoje os novos conflitos e contradições culturais surgem sobre um pano de fundo globalista e economista. Os conflitos tradição/modernidade, Igreja/Estado, burguesia/proletariado já não estão mais no centro do mundo. 
Em tempos hipercapitalistas, onde triunfam o imaginário da competição e cultura de mercado, dando novos contornos aos domínios da vida social e cultural, nem mesmo a arte é poupada. A cultura-mundo ganha espaço quando o mercado coloniza a cultura e os estilos de vida, quando as mídias e os ciberespaços adquirem uma função primordial para a comunicação e deles surgem novas formas de percepção do mundo cada vez mais dependentes de uma rápida e eficiente interconexão.

Se na idade moderna as maiores mudanças na esfera cultural foram marcadas pela dinâmica da ideologia individualista, na hipermodernidade o grande poder econômico, da globalização e da mercantilização, é que se impõe como o principal interesse da produção cultural.

A cultura nos tempos do hipercapitalismo é marcada pela grande força da oferta mercantil, pela abundância de informações e de imagens, pela imensa variedade de marcas e produtos. Diante de uma infinidade de escolhas, o consumidor tem o mundo à sua disposição por meio dos livros, das comidas, da moda, dos filmes, das músicas. Nunca descobrimos tanto viajando por diversos lugares culturais. Revela-se um cotidiano cada vez mais marcado pela variedade de experiências consumistas, onde os sujeitos dispõem de elementos de significação cada vez mais diversificados para consolidar sua existência, tamanha a circulação de bens, informações e modelos de referência. A cultura global desmantela os limites culturais dos territórios, da individualização dos sujeitos e dos modelos de vida: “As forças de unificação global progridem no mesmo passo que as da diversificação social, mercantil e individual. Quanto mais as sociedades se aproximam, mais se desenvolve uma dinâmica de pluralização, de heterogeneização e de subjetivação" (LIPOVETSKY; SERROY, 2011, p. 16).

Segundo o filósofo Douglas Kellner (1992), os meios de comunicação como a televisão e outras formas de cultura midiática de massas desempenham um importante papel para a renovação do conceito de identidade nos dias atuais. Seu estudo dos heróis televisivos e do simbolismo latente na publicidade mostrou que a identidade constrói-se a partir do lazer, da imagem e do consumismo oferecidos pela cultura de massas dominante que substituiu os tradicionais mitos e rituais. Ganham força "a integração dos indivíduos na ordem social, a celebração dos modelos culturalmente dominantes, a oferta de modelos de pensamento e comportamento e a resolução das contradições sociais" (CARVALHO, 1999, p. 731). 
Toda essa gama de padrões de comportamento disponíveis provoca no homem contemporâneo uma forte sensação de insegurança existencial que é alimentada "pela fluidez do mercado de trabalho, pela fragilidade do valor atribuído a habilidades e competências do passado ou que se busca adquirir no presente, pela reconhecida vulnerabilidade dos vínculos humanos e pela suposta precariedade e revogabilidade dos compromissos e parcerias". Sendo assim, esses sujeitos, enquanto parte integrante de um mundo fluído, desregulamentado e individualizado, confusos diante do futuro e perdidos frente ao lugar que ocupam no mundo, são vítimas da mixofobia, ou seja, "aquela sensibilidade alérgica e febril aos estranhos e ao desconhecido" (BAUMAN, 2004, p. 139).

Segundo Lipovetsky (2007), vive-se diante das culturas do "aviltamento" e da "culpabilidade", de modo que o hedonismo dissemina entre nós um clima de ansiedade e violência responsável por um verdadeiro arsenal de decepções que atingem, sobretudo, os desejos não materiais. Tudo isso está ligado aos sentimentos de histeria e excitação provocados pelo chamado hiperconsumismo, que absorve todo gênero de aspiração humana, provocando uma mudança repentina dos padrões éticos tradicionais chegando até mesmo à esfera política. A atual cidadania hipermoderna e seus paradoxos levam a pensar se a tão sonhada democracia também não seria um bem de consumo como qualquer outro.

A decepção moderna tomou proporções além do esperado, radicalizando-se. $\mathrm{O}$ sentimento de decepção em relação à vida sempre esteve atrelado a uma falta de sentido do ser, a uma sensação de insatisfação existencial em todas as áreas da atividade humana. Cada um vive num mundo à parte, imerso numa filosofia do consumo que legitima o individualismo, a moda, o hedonismo e o nomadismo tecnológico e afetivo. Interessa analisar, por meio das canções selecionadas, se estes fenômenos, que impõem determinados comportamentos moldados e difundidos pelo marketing, tornaram-se a base da felicidade em tempos hipermodernos.

As possibilidades de escolha parecem cada vez mais amplas diante de inúmeros estilos de vida, de modo que a não configuração em determinado modelo idealiza-se como algo intolerável e frustrante: "Eis no que consiste o império da decepção: liberdade estendida a todos os domínios da vida humana, sobre um fundo de liberalismo áspero e falta de convicção. Daí 'o cansaço de si mesmo', os elevados números de 
suicídio, a depressão, as diversas dependências...” (LIPOVETSKY, 2007, p. Prefácio $\mathrm{x})$.

Bauman (2011, p. 7) também traça o seu panorama do que chama de "mundo líquido moderno":

O mundo que chamo de "líquido" porque, como todos os líquidos, ele jamais se imobiliza nem conserva sua forma por muito tempo. Tudo ou quase tudo em nosso mundo está sempre em mudança: as modas que seguimos e os objetos que despertam nossa atenção (uma atenção, aliás, em constante mudança de foco, que hoje se afasta das coisas e dos acontecimentos que nos atraíam ontem, que amanhã se distanciará das coisas e dos acontecimentos que nos instigam hoje); as coisas que sonhamos e que tememos, aquelas que desejamos e odiamos, as que nos enchem de esperanças e as que nos enchem de aflição.

$\mathrm{Na}$ hipermodernidade desenvolve-se o domínio técnico sobre o espaço-tempo e diminuem as forças interiores do indivíduo. O enfraquecimento das normas coletivas resulta num sujeito tendencialmente fraco e desestabilizado. Quanto mais identidades sociais o indivíduo assume, mais surgem manifestações de esgotamentos e crises subjetivas. Quanto mais ele quer viver intensa e livremente, mais se acumulam os sinais do peso de viver.

No seu A sociedade da decepção (2007, p. 41-42), Lipovetsky aborda os quatro elementos responsáveis pela disseminação do sentimento de decepção no meio das estruturas sociais. Em primeiro plano está a questão da descrença nas utopias e na classe dirigente. Em pleno século XXI, e longe da realidade dissimulada pelas megasideologias do século passado, a sociedade tornou-se mais crítica em relação a seus governantes e aos discursos propagados pela mídia. Em segundo lugar, o sistema dos direitos humanos que, enquanto uma "utopia abstrata" baseada na "doutrina moral das democracias liberais", apresenta uma realidade desastrosa: "Sem dúvida, como o real poderia competir com ideais tão excelsos como liberdade, igualdade e felicidade geral?”. E continua: “À luz dos direitos humanos, a ação política concreta revela-se forçosamente calculista, injusta, sempre inferior às perspectivas ideais e a tudo que se refere ao respeito universal pelo ser humano. Daí provém a fornalha sempre viva do desencanto, cujas labaredas estão bem longe de se extinguir".

A nova fase do capitalismo marcado pelo liberalismo e pela modificação da economia, principalmente no campo das finanças, seria o terceiro fator de decepção. Foi ela a responsável por diminuir radicalmente as margens de manobra do poder público somado ao seu grande controle sobre a economia global. Portanto, ganha força a teoria 
de que o indivíduo contemporâneo é mais governado pelo poder velado dos fluxos financeiros do que pelos representantes eleitos pelos cidadãos.

O quarto e último fator aborda os discursos políticos e sua retórica que não é capaz de provocar o entusiasmo em ninguém. Usa-se um "linguajar asséptico, tecnocrático, sem farpas", o "politicamente correto" que diante da população parece uma forma fria, abstrata e complexa frente às suas necessidades e angústias:

Com esse processo de individualização intenso de nossas épocas, as grandes instituições perderam seu antigo poder de regulamentação social. As religiões, os partidos políticos e os sindicatos cada vez menos influenciam as crenças e os comportamentos individuais. Isso provoca instabilidade, vulnerabilidade psicológica extrema, ou seja, um indivíduo desorientado que busca alguma forma de integração comunitária em grupos, em "seitas", por vezes em núcleos violentos radicais. Daí derivam novos perigos, já não provenientes das maiorias poderosas, mas de minorias agitadas. [...] $O$ edifício liberal não desmorona, mas os danos causados em algumas partes da construção não são desprezíveis. (LIPOVETSKY, 2007, p. 62)

A sociedade da decepção é aquela na qual os sujeitos experimentam a dificuldade de assumir o próprio desgosto ou insatisfação, principalmente por pertencerem a uma sociedade onde o insucesso é visto como evidência do fracasso, onde é preferível provocar a inveja do que a compaixão. Nos tempos atuais, construir uma identidade não é tarefa fácil, visto que o indivíduo não conta mais com o alicerce dos antigos padrões de conduta social e religiosa. Logicamente, quanto mais sente o peso da responsabilidade sobre si, mais inevitável irá sentir a dor da decepção.

Do ponto de vista das relações de mercado, da competitividade e do extremo individualismo, a sociedade hipermoderna é retratada através dos sujeitos insensíveis ao próximo, compulsivos pelo dinheiro e pelo interesse pessoal, numa espécie de obsessão pelo cada um por si. No entanto, a realidade também apresenta outros pontos a serem observados. O individualismo problemático não significa total descaso em relação às necessidade do outro; os sujeitos ainda demonstram o devido valor pelos ideais de respeito, auxílio mútuo e solidariedade. O hiperindividualismo também é explicado pela transformação do lugar do indivíduo na sociedade. O advento da sociedade de consumo e da comunicação de massa acaba por difundir os ideais do hedonismo que associam os sentimentos de prazer e bem-estar à atitudes de mudança de hábitos, ao desejo de viver a sua vida fora de cenários convencionais.

Lipovetsky (2007, 75-76) segue traçando o perfil dos novos modelos sociais presentes nas canções analisadas nesse trabalho: 
[...] tudo quanto ostenta um matiz de "transgressão", radicalismo ou subversão tende a de dissolver na atmosfera difusa do consumo e da comunicação. Os hippies e os punks saíram de moda; a boemia e o inconformismo foram assimilados pela nova burguesia "conectada"; os livros subversivos são vendidos a preço de ouro; o luxo beira a provocação. É evidente que as novas sociedades liberais "aguentam" muito bem os golpes desferidos pela contestação, inclusive dos setores que se dizem mais radicais. Se a subversão não existisse, seria preciso inventá-la.

Tudo isso revela uma sociedade "vertiginosamente criativa, que se alimenta de seus próprios desvios para se auto-renovar e reinventar constantemente" (LIPOVETSKY, 2007, 75-76). Muitos dos prazeres contemporâneos são baseados em frivolidades, fruições passageiras, pequenos, e grandes, luxos, de algum modo esta é uma dimensão do desejo e da existência humana. É notório que em tempos hipermodernos o consumismo é representativo de uma nova realidade: mais do que possuir, importa parecer que se possui. A ostentação é o que prevalece, a recente moda do "funk ostentação" representa essa tendência, numa espécie de propaganda midiática de si ela é responsável pela conversão do valor econômico de um bem em valor simbólico cultural que indica, consequentemente, o valor de um ser humano em comparação com o Outro. Uma joia, roupas de grife, um carro e uma casa de luxo: todos se tratam de metáfora do que se é. Compra-se não somente pela utilidade do produto, mas por uma necessidade de reconhecimento.

Apesar dos incontáveis motivos para a insatisfação e a decepção, da mesma forma são numerosas as possibilidades de renovação, de revigoramento. Quanto mais frustrante é a sociedade, mais ela proporciona condições necessárias de reviver a esperança da felicidade: "ao ampliar o futuro e suas opções, a sociedade hipermoderna aumenta as nossas potencialidades de agir, de refazer a vida, de recomeçar a caminhada com pés renovados" (LIPOVETSKY, 2007, 80).

É interessante observar que frente à necessidade de uma análise criteriosa de diversos aspectos contemporâneos, muitos movimentos tendem a incriminar somente o consumismo desenfreado como opositor aos bens da alma e do espírito capazes de salvar da grande onda de decepção. De acordo com Lipovetsky (2007), não são os bens materiais que mais faltam ao sujeito hipermoderno, tanto que, frente a uma lógica que condena o modelo consumista, como explicar o grande apelo das iniciativas sociais e associações beneficentes? O autor de A era do vazio e Tempos hipermodernos também é reconhecido por sua visão diferenciada acerca da "era do consumo". Segundo ele, o 
hiperconsumismo foi, de todas as correntes filosóficas do século $\mathrm{XX}$, a maior responsável por alterações na vida social, tanto para o bem quanto para o mal. Para o bem, visto sua vital influência para o desenvolvimento e manutenção da "máquina liberal". Para o mal, devido à concepção de que as mais variadas relações da vida humana, (preço/atributo, prazer/desconforto, competitividade/descrédito), estão baseadas em esquemas típicos do consumo.

Sem identificar projeções para o futuro, o desnorteio do sujeito contemporâneo está presente em diversos âmbitos sociais: nas Igrejas, que já não regulam as crenças e comportamentos, nas ações políticas cada vez mais desacreditadas, na economia com o capitalismo globalizado visto com insegurança e ansiedade. A vida social e íntima também foi afetada: a família, a criação dos filhos, os relacionamentos conjugais, a alimentação, a moda sofrem alterações importantes provocadas pela onda de incerteza. Após o período moderno do engajamento, chega o tempo hipermoderno da "Grande Desorientação" que aumenta o caos intelectual e a insegurança psicológica. Também cresce o mal-estar cultural e ético da civilização, onde, mesmo hipertrofiado pelo mundo hiper, o sujeito sempre deseja mais e melhor do mercado que governa tudo.

É forçoso notar que em nenhum outro momento da história o homem teve seus desejos e necessidades tão atendidas: o prolongamento da vida, o desenvolvimento da medicina, o reconhecimento do papel feminino na sociedade, a liberalização dos costumes, os avanços na educação, no nível de vida, nas ciências e na tecnologia. No entanto, como compreender um mundo tão depressivo, causador de tamanha ansiedade, inquietações de todo tipo e cada vez menos otimista diante do futuro? Vejamos:

No cenário da existência luxuriante de um mundo que promete a felicidade de satisfações incontáveis e sempre renovadas, cresce uma imensa desorientação individual e coletiva. [...] Nos tempos do capitalismo absoluto, em que tudo é concorrência, em que tudo prolifera e se multiplica ao infinito, é preciso ser sempre mais moderno, reativo, informado, eficaz, o que não se dá sem pressões provocadoras de ansiedade e dúvidas sobre si próprio. Não é mais da carência que nasce o desnorteio; é do hiper. É ele que convém interrogar. (LIPOVETSKY; SERROY, 2011, p. 23-24)

Esse panorama é representado na canção "Essa pequena", uma espécie de jazz que aborda o amor entre uma jovem e um homem mais velho, numa referência aos modelos de relacionamento típicos da hipermodernidade integradora. Também será discutido, por meio das imagens presentes nessa letra, questões que tratam da relação 
entre passado e presente, além da influência do fenômeno da globalização na cultura das novas gerações.

Refletindo sobre o conceito de felicidade, observa-se um enorme abismo, que dificilmente pode ser preenchido, entre a expectativa e o concreto, entre o princípio do prazer e de realidade, de modo que desejo e decepção caminham juntos. Dona de um destaque sem precedentes nas áreas psicológica e social, a decepção é inerente ao sujeito, de forma que a individualista e democrática civilização moderna, na voz dos seus filósofos pessimistas, afirmou não existir a possibilidade de uma existência feliz, já que o eterno desejo e busca pela felicidade conduzem a uma permanente decepção: "Toda a literatura moderna - de Balzac a Stendhal, de Musset a Maupassant, de Flaubert a Céline, de Tchecov a Proust - é pontilhada pelos temas do tédio, do rancor, da frustração, do fracasso, das 'ilusões perdidas', das agruras próprias à existência" (LIPOVETSKY, 2007, p. 5).

$\mathrm{O}$ avanço dos conhecimentos científicos contribuiu muito para o que se sabe hoje acerca do universo e do próprio ser humano, mas, por outro lado, na medida que cresce o conhecimento e a autonomia dos indivíduos, crescem também as angústias e a responsabilidade para administrar tamanha liberdade. Tais conhecimentos não contribuíram para a felicidade da humanidade, de fato, a maior consequência deste conhecimento é, antes de tudo, o advento de um mundo e de uma existência mais complexos.

A "qualidade de vida", seja na vida conjugal, na sexual, na moradia, na alimentação e no lazer, tornou-se a meta das expectativas individuais. Quando a felicidade é prometida e os prazeres enaltecidos a todo momento, mais a vida cotidiana fica a mercê do desapontamento. Temos agora a cultura da ansiedade, da frustração e da decepção, reflexo dos valores hedonistas, dos fluxos de informação, dos ideais psicoculturais e dos múltiplos papéis que dão origem a um sujeito mais introvertido e exigente, mas, ao mesmo tempo, mais vulnerável.

Por outro lado, a letra de "Sem você 2" ("Pois sem você/ O tempo é todo meu/ Posso até ver o futebol/ Ir ao museu, ou não [...]") trará a temática do fim do relacionamento amoroso, onde o contexto hipermoderno torna as separações possíveis fontes de descobertas de um mundo novo, afastando de vez a ameaça do descontínuo e o medo da separação tão presentes nas letras poéticas buarqueanas nos anos de 1970. 
Pode-se citar a canção "Pedaço de mim"4 (77-78) como exemplo dessa fase. Vê-se um eu-lírico passivo diante do sentimento de perda amorosa e marcado por uma profunda dor que resulta até mesmo na imagem da "amputação", onde o indivíduo perde sua metade, representada na figura do sujeito amoroso, a partir da separação do par ("Que a saudade dói latejada/ É assim como uma fisgada/ No membro que já perdi”).

Outra ideia que fundamenta o fenômeno de uma civilização cujos modelos aumentam sem precedentes as ocasiões para a experiência frustrante, trata da desregulamentação e do enfraquecimento dos aparelhos religiosos de socialização nas sociedades hiperindividualistas. Essas sociedades já não possuem mais o antigo arsenal de convicções prontas e acabadas que abrandavam seus sofrimentos diante das decepções cotidianas, devendo cada um buscar suas próprias “tábuas de salvação", seja por meio do incentivo contínuo ao consumo, à fruição ou à mudança. Dessa maneira, os dispositivos regulados de modo comunitário por meio da religião deram lugar a diversos e desregulados modelos paliativos que compõem o universo individualista da livreopção.

Ao procurar respostas para seus anseios em plena hipermodernidade, as pessoas esbarram no universo de racionalidade da modernidade ainda presente em instituições religiosas "burocratizadas" que não praticam uma relação mais direta e sensível de louvor pelo divino. Surgem, então, novas religiões de caráter emocional como resultado do sentimento de decepção frente aos convencionalismos e as divagações das igrejas tradicionais. É certo que o sujeito hipermoderno ainda não encontrou uma forma plena de acabar com a angustiante busca de engrandecimento espiritual e de consagrar-se inteiramente a um ideal religioso. No entanto, vemos seu esforço em dividir suas vivências sensíveis com o outro em variadas tentativas e experimentações religiosas, “em suma, o enfático reavivar da propensão a crer não provém tanto do intumescimento ou da exacerbação da oferta de mercado quando da ausência de um senso de coletividade e de inserção comunitária” (LIPOVETSKY, 2007, p. 31-32). O eu-lírico da canção "Querido diário", envolto no conturbado contexto hipermoderno, revela essa preocupação:

\footnotetext{
${ }^{4}$ Oh, pedaço de mim/ Oh, metade amputada de mim/ Leva o que há de ti/ Que a saudade dói latejada/É assim como uma fisgada/ No membro que já perdi.
} 
Hoje pensei em ter religião

De alguma ovelha, talvez, fazer sacrifício

Por uma estátua ter adoração

Amar uma mulher sem orifício

Émile Durkhein (1907) foi um dos estudiosos a discutir o reinado da decepção e do descontentamento nas civilizações modernas individualistas. Ele observou que faltam parâmetros apropriados para avaliar a viabilidade dos desejos em meio a um contexto de estratificação social e ausência de leis, regras ou normas de organização. A modernidade, e seus modelos de sociedade, possibilita que os sonhos "voem alto", ganhando proporções mirabolantes. Tal liberdade e desejo de alcançar sempre mais aumentam o risco de aborrecimentos e de sofrer a dor de ver seus sonhos frustrados. Já nas sociedades antigas, os indivíduos viviam de acordo com sua condição social, desejando o que lhes parecia possível de se obter e com isso as decepções ocorriam numa dimensão bem mais restrita.

A modernidade em seu momento triunfal foi caracterizada por um surto de otimismo: "uma fé indestrutível na marcha irreversível e contínua rumo a uma 'idade de ouro', augurada pela dinâmica da ciência e da técnica, da razão ou da revolução" (LIPOVETSKY, 2007, p. 9). No entanto, o momento atual apresenta a ruína das velhas utopias e o esvaziamento dos mitos, sobretudo quando se pensa na edificação do futuro.

A convicção de um futuro indefinidamente melhor é desmantelada pelas tragédias do século XX somadas às novas perspectivas acerca dos perigos tecnológicos e ecológicos dos novos tempos. As profundas incertezas nascidas nesse contexto geraram o ideal de pós-modernidade, no entanto, apesar do descrédito dos sistemas progressistas e do desencanto com as ideologias, ainda prevalecem expectativas democráticas ligadas à justiça e ao bem-estar. Tudo isso reforça a sensação de confusão, desconforto e angústia.

A lógica excessiva da hipermodernidade se manifesta por meio da mercantilização desenfreada dos seres e dos objetos, invasão das técnicas em todos setores da existência, fragilização dos indivíduos, avançada perda do senso comum e do bem público. Esse panorama nem um pouco otimista resulta numa sensação de cansaço diante do mundo atual.

Segundo Lipovetsky (2007, p. 61), o sujeito hipermoderno procura soluções particulares para seus problemas particulares. É uma via hiperindividualista psicológica que progride rapidamente em lugar da via política, sendo essa a maneira mais comum 
de descobrir uma resposta para esse atual mal-estar na civilização. Ainda segundo o autor: "A segunda revolução individualista enfraquece as defesas psicológicas dos indivíduos, mas consolida as instituições democráticas".

As correlações entre o consumo e a decepção vão ganhando um alcance cada vez maior em tempos "hiper", chegando até menos à vida privada. Partindo da premissa, elaborada ainda pelos primeiros estudiosos do fenômeno "consumista", de que a farra do consumo é responsável pela origem de nossas carências e desgostos, observamos a existência de um movimento compulsivo que aumenta ainda mais a insatisfação frente ao sistema de mercado. Ocorre que a sociedade de consumo incita a viver numa condição de contínua carência, levando a desejar bens que nem sempre podemos comprar. E mais, o mercado sempre “impõe" bens de consumo mais requintados, disseminando o sentimento de decepção frente ao que já possuímos e que se tornou obsoleto.

Dessa forma, estamos sempre descontentes pensando em tudo que não podemos conquistar, cada vez mais distantes da sensação de completude enquanto hiperconsumidores. Nessa desenfreada busca por prazer não é o valor do produto que importa, mas seu poder de novidade em meio à penosa rotina, a experiência e gosto de aventura que ele pode proporcionar. Enquanto produzir elementos que gerem prazer e que sirvam de recurso para romper com a monotonia do dia-a-dia, o consumo proporcionará mais satisfações do que desapontamentos.

A sensação de irritação e descontentamento também se faz presente na vida do novo consumidor que anseia por velocidade e imediatez. As mensagens embutidas nas novas tecnologias iludem, de forma que um pequeno defeito ou limitação provoca decepção e fúria. Até a alimentação converteu-se em fator de ansiedade graças aos produtos geneticamente modificados, aos açucares, gorduras, corantes que fazem parte da nossa rotina apesar de considerados nocivos à saúde. O ato de se alimentar está cercado de culpa em nossos dias graças à obsessão em torno das dietas e do corpo ideal, tudo isso apoiado pela influência da mídia que impõe um padrão de beleza exclusivo e se faz de porta-voz dos temas médicos.

Vivemos um momento em que a cultura se destaca como importante elemento da vida econômica, onde questões culturais fragmentam o social, impulsionadas pelas indústrias do imaginário e do consumo que colocam em risco os valores do espírito bem diferente do período anterior à modernidade, onde as discussões acerca da cultura 
se concentravam nas relações entre cultura e Estado. Segundo Lipovetsky e Serroy (2011), o espetacular avanço dos problemas culturais na era hipermoderna devem-se a três séries de fenômenos.

O primeiro trata da dimensão econômica da cultura, na qual ela é uma indústria responsável pelo crescimento dos países desenvolvidos. O mercado do imaginário e do ciberespaço ganha o território global de modo que, ao deixar de ser um setor marginal, a cultura do audiovisual agora é tratada em termos de mercado, negócio e lucro, sendo cada vez mais absorvida pelo capitalismo.

O segundo fenômeno aborda a comercialização exponencial da cultura. Observase o desfazer das antigas barreiras simbólicas responsáveis pela hierarquização entre a alta e a baixa cultura, a arte e o comercial, o espírito e o prazer:

\begin{abstract}
A época hipermoderna pôs em órbita o "tudo-cultural", baseado na dignificação e na igualização democrática dos conteúdos mais heterogêneos. Excrescência da cultura mercantilizada, relativismo cultural: daí surgiu todo um conjunto de polêmicas e de advertências contra a rebarbarização da cultura e, mais amplamente, contra a infantilização dos consumidores, o empobrecimento da vida social e intelectual. (LIPOVETSKY; SERROY, 2011, p. 25)
\end{abstract}

Do mesmo modo, vê-se a esfera cultural tornar-se cada vez mais politizada e conflituosa já que a transformação do cenário político mundial, com o enfraquecimento das estruturas estatais, também está fundamentada em elementos culturais, étnicos e nacionais. Esse é o terceiro fenômeno que dá conta de uma nova relação entre cultura e política na qual quanto maior a globalização do planeta, maiores serão os particularismos e o desenvolvimento das exigências identitárias. A politização da cultura produz uma mudança repentina num mundo onde a política envolvia-se apenas em assuntos de ordem econômica e das lutas sociais. Conforme Lipovetsky e Serroy (2011, p. 27-28), "se os grandes esquemas organizadores do econômico e do político são marcados pela redução das dissensões de fundo, a cultura é o que faz ressurgir oposições e divisões externas". No entanto, cabe perguntar onde há contradição entre capitalismo e cultura quando o que se observa é a crescente aproximação entre o capitalismo de consumo e a cultura individualista. A resposta apresenta o "retorno" da cultura como uma chance para o futuro num processo de grandes possibilidades e ações capazes de civilizar a cultura-mundo que hoje, em meio ao "capitalismo desorganizado", provoca um novo tipo de mal-estar da civilização: “[...] eis que em torno do 'cultural' recriam-se novas demandas, novas divergências, novos braseiros, 
que vêm atiçar outra vez os focos políticos e econômicos que compõem o fundo dos conflitos humanos".

A relação com o ideal de progresso torna-se paradoxal, oscilando entre a mitificação e o desencanto, o medo e a esperança. Na era hipermoderna a mitologia do progresso falhou, a dimensão da tecnociência converteu-se em algo incerto e problemático. Diversos fatores acentuam o sentimento de isolamento entre os sujeitos, de insegurança íntima, as vivências de fracasso pessoal e as crises subjetivas. Entre eles, o deteriorar das culturas de classe, a instabilidade dos papéis e das identidades sexuais, a desestabilização da vida profissional e afetiva, o enfraquecimento dos dogmas religiosos e dos laços familiares. Apesar de conectados com o mundo através das redes de comunicação, jamais houve um sentimento tão forte de isolamento entre os sujeitos, fundamentando, assim, a avalanche consumista que possibilita a cada um pequenas compensações pela ausência de amor, de reconhecimento e de afetividade. À medida que os laços afetivos se tornam mais frágeis e frustrantes, mais o consumismo se converte em fonte de "pequenas felicidades" e em meio de evasão diante dos próprios medos e desilusões.

A reviravolta no terreno afetivo segue a tendência do hiperconsumismo. A cultura consumista é uma invenção recente na história que teve início no final do século XIX e ganhou magnitude a partir da década de 1950. Esboçando o futuro, Lipovetsky (2007, p. 83-84) acredita que uma cultura não tem duração infinita e, por isso, no futuro, a primazia do consumismo será revogada por não ser compatível com a condição humana. A felicidade dos indivíduos não cresce na mesma medida em que se acumulam as riquezas. Diz o filósofo:

[...] penso em uma reviravolta cultural que promova a reavaliação das prioridades da existência, da hierarquia das finalidades, da função dos prazeres imediatos nesse novo sistema de valores. Em dado momento, os homens descobrirão o lado "picante" da vida longe do hedonismo consumista, sem que a humanidade tenha de abandonar a idade democrática: organizar-se-á uma espécie de "democracia pósconsumista". [...] Novos objetivos empolgantes inflamarão o sentido da existência e traçarão outros caminhos para a felicidade.

Caminha-se por variadas experiências amorosas levados pelo desejo de conquistar o "amor eterno". Apesar de toda essa transformação, um relacionamento amoroso nunca será igual a uma relação qualquer de prestação de serviço ou comércio: "No âmbito do consumo, a ideia de modificação contínua corresponde à própria 
natureza da matéria, sendo, pois, altamente apreciada. No âmbito da vida amorosa, pelo contrário, equivale ao mais rotundo fracasso" (LIPOVETSKY, 2007, 20-21).

Diversas canções do álbum Chico discutem questões acerca dos relacionamentos amorosos. A valsa "Nina" aborda uma temática comum na hipermodernidade: a problemática dos novos padrões de relacionamentos amorosos. Ao narrar sua relação com Nina, uma jovem que nunca viu e que mora em Moscou, o eu-lírico aborda temáticas que exploram o grau de intimidade e a duração das novas relações amorosas, deixando para trás um legado de comportamentos pré-determinados quando o assunto é o relacionamento íntimo.

Em tempo de sociedade de consumo e comercialização da aparência e da saúde, é grande o esforço para dominar o corpo. Mas o corpo tem algo de indomável que não está relacionado à sua aparência, mas à sua existência. Assim sendo, a socialização do corpo é limitada por onde se avulta uma zona de individualização necessariamente inacessível:

Daí o lado selvagem da leitura, o lado de descoberta, de aventura, o aspecto necessariamente inacabado, incompleto dessa leitura, como de todo prazer. $\mathrm{O}$ corpo não está jamais perfeitamente integrado nem no grupo nem no eu. A operação de leitura é dominada por essa característica. $\mathrm{O}$ corpo permanece estranho à minha consciência de viver. (ZUMTHOR, 2007, p. 80)

Se, por um lado, os fatos corporais não são plenamente definidos por meio dos sentimentos e das lembranças, por outro, o corpo é nosso instrumento de manifestação. A poeticidade vem sintetizar esses aspectos por meio da sensorialidade: "Toda poesia atravessa, e integra mais ou menos imperfeitamente, a cadeia epistemológica sensaçãopercepção-conhecimento-domínio do mundo. A sensorialidade se conquista no sensível para permitir, em última instância, a busca do objeto". Por estar ligada aos nossos sentidos, a poeticidade está a serviço do conhecimento e, consequentemente, age sobre o sujeito, nutrindo-o: “Minha leitura poética me 'coloca no mundo' no sentido mais literal da expressão. Descubro que existe um objeto fora de mim” (ZUMTHOR, 2007, p. 81).

A importância da voz agrega-se aos valores da própria linguagem, quando essa é entendida como poética: “[...] escutar um outro é ouvir, no silêncio de si mesmo, sua voz que vem de outra parte. Essa voz, dirigindo-se a mim, exige de mim uma atenção que se torna meu lugar, pelo tempo dessa escuta. Essas palavras não definiriam igualmente bem o fato poético?" (ZUMTHOR, 2007, p. 84). 
A voz está relacionada à ideia de sociabilidade. Enquanto forma arquetipal, a voz, ao ser emitida ou ouvida, anuncia que não estamos sozinhos no mundo. A voz poética vai além, preenchendo o antigo vazio de sentidos possíveis.

De fato, a obra age como um emissor de mensagens variadas através dos tempos e cujo entendimento depende não somente da historicidade da própria obra, como da historicidade dos receptores. Ao se apropriarem da história, o sujeito dá um sentido para ela.

Zumthor (2007, p. 108) vai além, evidenciando essa íntima relação entre sujeito e obra: "Procuro minha própria história na singularidade do meu objeto; e ele encontra em mim, como em prospectiva, a sua. Encontra uma paixão: a minha; aquela em que meu discurso conseguirá talvez comunicar à minha volta”. Em entrevista à Brazucaonline (2010) Chico Buarque relata um pouco dessa confusão entre o real e o imaginário quanto trata de seus personagens:

$\mathrm{Eu}$ fico vivendo aquele personagem o tempo todo. Entrando no pensamento dele. Adquiro coisas dele. Você pode discordar, mas chega uma hora que tem que criar uma empatia ou uma simpatia. Você cria uma identificação. E alguma coisa no gene é roubado mesmo de mim, algumas situações, um certo desconforto, não saber bem se você é real, se você está vivendo ou sonhando aquilo.

Retomando o terceiro fenômeno, que trata da renovada relação entre cultura e política, Lipovetsky (2007) comenta que nos últimos vinte anos a dimensão da perda de confiança na classe política só aumenta em todos os países. Considerados incapazes de cumprir suas promessas de solucionar os problemas de desemprego, saúde, insegurança, o sistema político parece alheio às reais angústias dos eleitores. Esse clima de suspeita está ligado à ideia disseminada socialmente acerca da conduta dos homens públicos, onde a prioridade seria a satisfação de seus interesses pessoais que nutre um desencanto e desconfiança pela política. A ideia de progresso dissolveu-se dando lugar a dispositivos sociais de combate ao desemprego, à redução da dívida pública, à modernização dos órgãos administrativos e à estimulação do caráter competitivo das economias. Os grandes visionários são substituídos por governantes capazes de gerir as pressões inevitáveis do presente, controlando a crise e promovendo uma adaptação forçada da pátria ao mundo globalizante.

Frente a esse contexto não é de se espantar que os cidadãos se julguem vítimas de um imenso engano. O caminho para uma sociedade que se vê desorientada frente à ruína dos projetos políticos estruturantes é a descrença, o distanciamento da matéria 
pública, o declínio da militância partidária. Essa é a fórmula do individualismo hipermoderno: alienação em relação à temática pública, elevado investimento na satisfação pessoal, somados à influência da globalização cultural e à exaltação do consumo. Por isso, a caracterização política atual é substancialmente menos formadora de identidade social do que no passado.

É interessante notar que o desencantamento político hipermoderno não afeta diretamente a vida cotidiana, aí está outra característica da despolitização que está ligada a uma decepção mais difusa, que gera mais indiferença e distanciamento do que desânimo. $\mathrm{O}$ desencanto e pessimismo frente à matéria política também não diminuem a febre consumista, tampouco podemos dizer que o desejo crescente pelos bens materiais e pela vida particular esteja relacionado à desilusão provocada pela política ou esfera pública. Na verdade, esse comportamento é resultado da criação sistemática de novos mercados, de novas opções de lazer e de desenvolvimento individual. A canção atual de Chico Buarque reflete esse quadro. De acordo com o artista (2011): "Não me interessa hoje repetir em música o que está todos os dias nos jornais. Nem me interessa muito dar entrevista falando mal do governo. Eu gostava de falar mal do governo quando os jornais não o faziam”.

Todas as democracias contemporâneas estão marcadas pela dinâmica dos direitos humanos, da globalização liberal e da influência midiática. No entanto, algumas particularidades nacionais são definidoras do maior ou menor grau de decepção política. No caso da América Latina, a corrupção é a principal desencadeadora dessa sensação.

Diversos fenômenos como a corrupção, o utilitarismo mercantil e a globalização poderiam fundamentar uma análise niilista da hipermodernidade. $\mathrm{O}$ retrato diário divulgado revela uma modernização sem limites que se impõe por meio de ideais ligados à concorrência mundial, à perfeição, à rentabilidade, à batalha diário pelo sucesso: "serpenteia à nossa volta algo de um niilismo tecno-mercantil em meio ao triunfo dos negócios, das finanças e do tecnicismo" (LIPOVETSKY, 2007, p. 56). No entanto, Lipovetsky não considera a sociedade de consumo como a responsável pela consagração total do niilismo. Segundo ele,

[...] concluir isso seria tomar a parte pelo todo. Por quê? Os referenciais dos significados e dos valores não estão extintos. A democracia e os direitos humanos gozam de uma excepcional aceitação; as desigualdades não param de crescer, mas os protestos sociais não foram esmagados. Embora o equilíbrio ecológico esteja em risco, a consciência da obrigatoriedade de uma reação continua 
existindo. [...] A democracia tem todos os meios de se autocorrigir, para se reorientar, para se reinventar. A sociedade hipermoderna está sob o domínio do investidor e do consumidor, mas nem por isso se transformou em uma sociedade "pós-democrática", centrada em si mesma e desprovida de qualquer senso de justiça. (LIPOVETSKY 2007, p. 56)

Os referenciais de ordem moral não foram destruídos pela sociedade hiperindividualista, de fato a moral em tempo hiper abandonou o discurso tradicional e transferiu-se para os temas que antes eram indiscutíveis: aborto, adoção de filhos por casais homossexuais, manipulação genética, eutanásia. Vive-se o momento de grandes discussões que irrompem conflitos de natureza moral, de pluralização das éticas de acordo com o temperamento da nossa sociedade secularizada, democrática e individualista.

A felicidade prometida pela sociedade do consumo de massa ainda não se tornou realidade, assim como a consciência de que o bem-estar não pode ser obtido apenas pela posse de bens materiais, são fatores que esclarecem o retorno de uma filosofia que pretende responder à questão da felicidade.

O sujeito hipermoderno não espera mais um futuro promissor, ele mesmo busca criar as condições para sua felicidade no presente. De fato, no momento em que o indivíduo se converte em principal valor de uma sociedade, seu sucesso também se torna um ideal supremo. Acontece que em sociedades hipermodernas, onde impera o individualismo e o hedonismo, a tarefa solitária pela felicidade torna-se um martírio. Se o consumo de bens materiais não preenche o vazio interior, o caminho a ser tentado é o da atitude espiritual apoiado nos trabalhos de filósofos e mestres espirituais que enchem as prateleiras das livrarias. Partindo desse ponto de vista, cabe afirmar que o retorno nostálgico da tradição vai além de uma preocupação legítima com o bem-estar. Ela também envolve a extensão da lógica do consumo ao domínio da espiritualidade, dos relacionamentos, da busca pela felicidade.

De todo o modo, uma das hipóteses que investigamos por meio dessa pesquisa é que, apesar de todas as transformações nos modelos de comportamento, a canção atual de Chico Buarque permanece como uma forma de reação, desta vez contra a homogeneização da tradição cultural brasileira, conforme veremos nas letras das canções analisadas. 


\section{CHICO BUARQUE E O HOMEM DA CULTURA-MUNDO}

Na música popular brasileira, Chico Buarque consegue construir em imagens poéticas os desejos que habitam nosso imaginário, sublinhando-os por meio do ritmo e da melodia. Em meio à modernidade dos anos de 1960 e à cultura da Bossa Nova, o compositor, filho da elite intelectual carioca e paulista, foi responsável por aproximar a classe média da refinada ironia do samba. Sua "Banda" vitoriosa no festival da TV Record de 1966, valorizava a nostalgia interiorana em um país recém-urbanizado. O primeiro LP contém a marca dos sambas urbanos, corriqueiros, do homem da rua: o singelo morador das cidades tão cantadas por Chico.

A música popular dos anos de 1970, resultado do movimento de ruptura tropicalista e das perseguições, exílio e censura vigente em função do regime militar pós 1964, era caracterizada pela falta de fronteiras rítmicas, geográficas, históricas e ideológicas. As relações humanas e conceitos tradicionais, como o modelo patriarcal de família, mudam em consequência dos movimentos de contracultura pelo mundo que dá voz às chamadas minorias. A partir de um outro entendimento da relação melodia/letra, as composições pretendiam deixar um recado de ordem essencial.

Por habilitar o imaginário coletivo, a temática existencial reflete os anseios de um sujeito em contínua busca por compreender sua própria identidade marcada pelo convívio com o outro. Dentre tantas performances de destaque, considerando a performance resumidamente como a maneira como uma mensagem poética é transmitida e recebida no momento em que acontece, Chico Buarque "desenha uma melodia suspensa para encaminhar a pergunta brasileira da década: 'o que será que será?"” (TATIT, 2004, p. 230).

Por outro lado, os limites impostos pela censura ofereciam margem a diversas manobras criativas. Como imaginar os anos de governo militar sem a voz de Chico, ou seria Julinho da Adelaide, traduzindo, e também contradizendo, as fantasias brasileiras em tempos ufanistas? Nesse trajeto, o mercado de consumo tornava-se o maior parâmetro das produções artísticas: "Longe dos parâmetros subjetivos adotados na era dos festivais, agora eram as leis frias do mercado que determinavam os eleitos e os excluídos" (TATIT, 2004, p. 228).

Nos anos de 1980, um Chico mais discreto reabilitou seu próprio lirismo: “Em 1998, o homem da rua, que nunca deixou de habitar suas canções, voltou para provar 
que a síntese desse Brasil litorâneo, nostálgico, e rural se escreve a partir das imagens, das personagens e dos sons colhidos na efervescência das Cidades" (KEHL, In NESTROVSKI, 2002, p. 62). Refletindo sobre a relação entre o sujeito Chico Buarque e a "Cidade", palco principal da hipermodernidade enquanto elemento "vivo" em constante comunhão com os sentimentos e atitudes do eu-lírico, Moutinho (2011, p. 54) traz Italo Calvino, que no seu ensaio "Exatidão" do livro Seis propostas para o próximo milênio

[...] define a cidade como símbolo capaz de exprimir a "tensão entre a racionalidade geométrica e o emaranhado de existências humanas". Para o autor italiano, o espaço urbano, esse amálgama de topografia e afetos, é algo "legível". Portanto, a paisagem, os personagens, mas também os costumes, o cotidiano, a própria história, configurariam uma espécie de "cartografia simbólica" que se presta à decifração, sobretudo, por intermédio da arte [...].

Em um dos primeiros ensaios sobre a poesia de Chico publicado em 1973, "Chico Buarque: a música contra o silêncio" (2004, 161-162), Affonso Romano de Sant'Anna explica como as letras de Chico, até aquele momento, podiam ser divididas em duas fases: "A primeira seria exemplificada por seus três primeiros long-plays e a segunda pelo disco [...] Construção. Entre uma fase e outra está a peça Roda viva, encenada em 1968, sinal de ruptura com a imagem de bom moço que o sistema publicitário queria impor ao poeta". No primeiro momento, o simbólico presente nas imagens da banda, do samba e do carnaval, tão recorrente nas letras, traduz o "instante de utopia [...] cria o estado de exceção". A canção é "possibilidade de comunhão" que visa "romper o silêncio do cotidiano" revelando "as verdades que os homens querem calar". No segundo momento, o lirismo de "A banda" dá lugar "à dramaticidade do 'Cotidiano' e à tragédia da 'Construção". As "considerações líricas sobre os pequenos incidentes do dia a dia" dão lugar ao sujeito engajado "no exercício da construção musical, articulando tijolo com tijolo num desenho lógico".

Chico produz uma obra rica em imagens e símbolos, provida de grande cuidado formal, conteúdo denso, tensão verbal e abrangência ilimitada. O poder e a força do lirismo de um eu-poético sensível e constantemente atualizado, imerso na realidade dos sujeitos de seu tempo, revelam a experiência de ser humano, compondo seu acervo textual, seja por meio do lirismo, do humor, do drama ou da tragédia.

Esse estudo propõe e analisa uma terceira fase da obra musical de Chico Buarque, das composições nascidas em plena hipermodernidade, onde noções de 
hibridismo, individualismo e urbanismo se fazem presentes nas letras a partir da década de 1990.

Os versos de "Querido diário" servem como demonstrativo exemplar desse novo momento das composições do artista que dialogam com o espaço e a sociedade contemporânea, sem abandonar o lirismo da primeira fase que hoje se converte num dos principais recursos de reação e denúncia social das angústias e da pressão vividas pelo sujeito hipermoderno, numa reciclagem que remete a segunda fase da sua obra. Veremos principalmente por meio da nostalgia e do retorno à tradição um novo modelo da canção buarqueana fundamentado numa espécie de releitura das fases anteriores. A letra é composta pelo relato de um eu-lírico sobre seu cotidiano nos tempos hipermodernos das disfunções sociais ("Hoje a cidade acordou toda em contramão"), das angústias existenciais ("Hoje pensei em ter religião"), das relações fluídas e da necessidade de completude ("Hoje topei com alguns conhecidos meus/ Me dão bomdia, cheios de carinho/ Dizem para eu ter muita luz, ficar com Deus/ Eles têm pena de eu viver sozinho").

O "lirismo nostálgico" - já abordado por Adélia Bezerra de Menezes que no livro Desenho mágico: poesia e política em Chico Buarque (1982, p.40; 49) considerou a obra de Chico em três modalidades, "lirismo nostálgico, variante utópica e vertente crítica", sendo todas elas "uma forma de resistência" - está presente na produção artística atual de Chico, sendo o local onde se manifesta o "desejo de um retorno, a ânsia dolorida por uma volta a uma situação ou a um espaço que não fazem parte da realidade atual".

A "poesia resistência" foi inicialmente discutida por Alfredo Bosi em $O$ ser $e o$ tempo na poesia (2001). Para ele o poema remete ao tempo, não somente pelo que fala, mas inclusive pela estrutura, pela organização das palavras no tempo. Enquanto categoria fundamental do poema, o tempo forma e altera a consciência do ser, ou seja, o ser se define pela consciência e, portanto, pela poesia. Essa reflexão teve como perspectiva a resistência contra a opressão vigente durante a ditadura militar brasileira que levou Bosi a uma apropriada relação entre poesia e resistência, seja existencial, cultural ou política: 
Diante da pseudototalidade forjada pela ideologia, a poesia deverá ser feita por todos, não por um [...]. Essa "ser feita por todos" não pode se realizar materialmente, na forma de criação grupal, já que as relações sociais não são comunitárias. Mas acabou fazendo-se de algum modo, como produção de sentido contra-ideológico, válida para muito. (2001, p. 167)

Para Bosi, a resistência na forma de poema apresentava três faces: nostálgica, utópica ou crítica. Foi essa tipologia que inspirou o trabalho de Adélia Meneses sobre a relação entre poesia, história e política na obra de Chico Buarque. Na época, a autora citava a canção A banda (1966) como integrante do lirismo nostálgico. No entanto, também podemos observar diversas canções contemporâneas de Chico que se qualificam dentro dessa mesma modalidade, já que representam a recusa frente ao presente opressor, apelando para um passado no qual as relações humanas não eram desgastadas pela massificação e pela estandardização. Assim, a hipermodernidade não pode ser definida somente pela autocrítica dos saberes e das instituições modernas. Ela é também a memória revisitada, a remobilização das crenças tradicionais, a hibridização individualista do passado e do presente, como revela o confuso festival de memórias em "Barafunda" ("Foi na Penha/ Não, foi na Glória/ Gravei na memória/ Mas perdi a senha/ Misturam-se os fatos/ [...]"). A desconstrução dá lugar ao reemprego das tradições, livre de qualquer imposição institucional, ao ininterrupto rearranjar delas de acordo com o princípio da soberania individual. Daí a origem do poder de autocrítica e de autocorreção que continua a existir no universo democrático liberal.

A "poesia da resistência" de Bosi ainda pode ser aplicada em tempos hipermodernos, visto que suas modalidades rechaçam um panorama vivido ainda hoje por meio da recusa à realidade opressora, de mercantilização das relações, de medo e fragilidade que vivemos. A revolução do cotidiano, com os profundos distúrbios nas aspirações e nos modos de vida criam um novo sujeito em plena primazia do presente.

"Tudo o que é novo apraz", esse é o princípio que se impõe. Vive-se um presente que substitui a ação coletiva pelas felicidades particulares, a tradição pelo movimento, as esperanças no amanhã pelo deslumbre do presente sempre novo. Formase uma cultura hedonista que incentiva a satisfação imediata das necessidades, estimula a urgência dos prazeres, exalta a conquista pessoal, a cultura do conforto e do lazer. As políticas do futuro radiante foram substituídas pelo consumo como promessa de um futuro eufórico. 
Diante de um mundo em constante e veloz transformação, não seria surpresa afirmar vivencia-se uma outra fase: eis o momento do desencanto com a própria pósmodernidade, da desmistificação da vida num presente confrontado com a escalada das incertezas. O alívio é convertido em fardo, o hedonismo recua diante da insegurança, chega-se ao paradoxo de frivolidade e ansiedade, de euforia e vulnerabilidade que desenham a hipermodernidade.

Toda literatura, toda poesia, quer queiramos, quer não, é engendrada de um solo cultural: histórico, social, político. No entanto, em tempos adversos como o nosso, nunca a grande poesia duplica valores e ideologia dominantes, mas necessariamente rompe com eles. Num mundo massificado, homogeneizado, de exploração generalizada, com a globalização concentracionária campeando; de consumo e obsolescência programada, sociedade da mídia e da cultura do espetáculo, como poderia a grande poesia ser de adesão? (MENESES, 2003)

Para além do reconhecido sentimento romântico e sentimental de sua obra, Chico Buarque também é compositor de sucessos de caráter "social" onde apresenta a dualidade entre o mundo do lazer e do trabalho, o fato de que vive-se duas vidas, a pessoal e a social, e que ambas muitas vezes não se misturam.

Edifica-se o sujeito "hipermoderno" que se expõe na difícil integração da realização do desejo pessoal no seu papel social inexorável. Segundo o crítico Lipovetsky (2004), a hipermodernidade é integradora. Daí surge um novo paradoxo contemporâneo: sujeitos que buscam a reintegração do ser em meio ao fragmentado mundo "hiper". Os indivíduos vivem assolados pela imediatez, confusão e velocidade desse tempo, sem abandonar a busca pela compreensão da condição humana em completude.

\footnotetext{
A literatura espelha, assim, esse indivíduo transitório, (sobre) vivente em um mundo líquido, fragilizado pela suspensão das antigas certezas (família, religião, pátria) que serviam de alicerce, mas também de barreira confortável (pois indutora de comodismo) para sua constituição. (CYNTRÃO, 2013, p. 370)
}

Pioneiro na análise crítica das letras poéticas de Chico, o professor Anazildo Vasconcelos da Silva apresenta um importante panorama da obra do artista que exalta principalmente seu valor poético somado às discussões de cunho social. Ao caracterizar a canção de Chico como "universal" e não "circunstancial", Silva também contribui para essa pesquisa que considera a produção atual de Chico Buarque enquanto representação do imaginário hipermoderno. 
Combatendo as interpretações que generalizavam a canção de Chico Buarque ao contexto circunstancial das canções de protesto, Silva (1974, p. 13) defende a existência de um projeto poético buarqueano concebido através da elaboração intertextual de um referente poético vinculado a uma produção lírico-musical que extrapola sua localização temporal. Assim sendo, as composições de Chico transcendem o panorama político do momento histórico para se tornarem obras artísticas de fato, em outras palavras, objetos estéticos que perduram frente ao tempo e ao contexto da sua criação.

O olhar poético do compositor volta-se para sujeitos comuns, destituídos de traços nobres ou heroicos, constituindo-se como um reflexo da realidade. Júlio Cesar Valladão Diniz (2004, p. 259) denomina esse olhar poético de "lirismo prosaico". Segundo o autor, trata-se de uma poética acessível aos temas prosaicos do cotidiano, cujas marcas contemplam a

[...] observação das manifestações sociais e culturais como celebração (o desfile da banda, a festa do carnaval) e [...] o forte sentimento de nostalgia diante de um mundo que perdia a sua inocência, ligado à ideia de que a música reafirma a possibilidade utópica de transformação política e social, um certo retorno ao paraíso e suas visões, atitude de afirmação de uma ideia de identidade nacional a ser construída.

Essa nostalgia também permeia as composições de Chico sob um novo olhar poético, mergulhado num novo contexto social.

O eu-lírico em Chico Buarque qualifica-se como porta-voz das angústias da sua comunidade. Dessa forma, não seria equivocada uma reflexão metafísica do artista, onde a angústia existencial se desloque do plano concreto da realidade social, para o eixo subjetivo da consciência do eu-lírico. Enquanto artista comprometido com a vida, Chico exalta em sua obra a façanha humana de existir, de compartilhar a experiência existencial com o Outro. Na constante procura pelo sentido da vida, e da sua própria existência, ele narra os acontecimentos da história de um eu-lírico conectado à problemática humano-existencial e não isolado em sua individualidade, marca que se opõe à tendência hipermoderna de culto ao individualismo.

De fato, o regime hipermoderno mantém elementos da estética pós-moderna: o culto ao hedonismo, a preocupação com a sedução, a divulgação do cotidiano, a valorização das emoções e das percepções, a escassez das correntes artísticas e o fortalecimento das iniciativas individualizadas. No entanto, observa-se uma mudança de tom, o movimento não é mais exatamente o mesmo. Segundo Charles (2009, p. 120- 
121), abandona-se o gozo libertário pelas dificuldades da vida atual. Os artistas não ficaram insensíveis a esse novo panorama e ao surgimento desse "enrijecimento atual" que se amplia a partir de duas formas de individualidade: a primeira é a individualidade dos seduzidos pela lógica do consumo hipermoderna, que esperam desse mundo prazeres e satisfações; a outra trata daqueles que não se adaptam a essa lógica hiper, são os frustrados ou excluídos do sistema. Observa-se ao longo da história que a literatura dá voz a estes invisíveis sociais, num processo que nunca deixou de se ampliar e tem Chico Buarque como um dos seus mais conhecidos representantes na atualidade.

Silva (2013, p. 73) já observava na obra de Chico, a partir dos anos de 1990, a ampliação de uma temática ligada à reflexão sobre a transcendência na relação do artista com sua obra. A essa nova perspectiva, onde o artista concebe a permanência da obra independente dele, o estudioso denominou de "A poética transcendental":

O poeta considera, por exemplo, a relação do artista com sua obra diante da consumação do tempo histórico, vislumbrando no olhar transcendente a presença indelével do criador em sua criação, como no trecho "Palavra minha / Matéria, minha criatura, palavra / Que me conduz / Mudo / E que me escreve desatento, palavra", de "Uma palavra", de 1989, evidenciando que o autor e obra se produzem um no outro mutuamente.

A canção "Tempo e artista" (1993) também é exemplar dessa fase onde Chico reflete sobre a transcendência em sua obra.

Imagino o artista num anfiteatro Onde o tempo é a grande estrela

Vejo o tempo obrar a sua arte

Tendo o mesmo artista como tela

Modelando o artista ao seu feitio O tempo, com seu lápis impreciso

Põe-lhe rugas ao redor da boca

Como contrapesos de um sorriso

Já vestindo a pele do artista

O tempo arrebata-lhe a garganta

$\mathrm{O}$ velho cantor subindo ao palco

Apenas abre a voz, e o tempo canta

Dança o tempo sem cessar, montando

O dorso do exausto bailarino

Trêmulo, o ator recita um drama

Que ainda está por ser escrito 
No anfiteatro, sob o céu de estrelas

Um concerto eu imagino

Onde, num relance, o tempo alcance a glória

E o artista, o infinito

Essa é uma canção que traduz a relação do artista com o tempo e evidencia a maturidade da obra do artista que, na ocasião do lançamento do álbum "Paratodos" (1993), estava prestes a completar 50 anos de idade. De acordo com Menezes (1995, p.78):

"Tempo" aqui não é mais a roda-viva que dispersa, agita e destrói, o tempo/vento, lufada impetuosa que tudo leva "para lá", mas é o tempo que, identificado à experiência viva do próprio artista, age por ele e nele. Muito mais que o tempo de Roda-viva (1968), é ao "tempo da delicadeza" de Todo o Sentimento (1987) que ele se religa: "Um tempo que refaz o que desfez/ Que recolhe todo sentimento/ E bota no corpo uma outra vez". Somente a maturidade poderia abrigar essa dimensão, a da reparação.

O tempo agora apresenta sua faceta poética que constrói, fortifica e amadurece o sujeito. O tempo também é o artista, é poder de criação. Chico Buarque em entrevista ao jornal Folha de São Paulo ${ }^{5}$ afirmou que "Em relação à música, eu sou um autor muito mais passivo do que na Literatura. É evidente que sou um músico intuitivo e não sou um escritor intuitivo", essas palavras representam a ideia de que existe o momento da ação do artista, mas que, por outro lado, existe o momento em que se deixa o tempo agir. Essa ideia de passividade propicia o espaço para a expressão do tempo enquanto sujeito da letra poética, ele é senhor da ação na maioria dos verbos do poema. É ele quem absorve o artista, quem canta, dança e finalmente alcança a glória: “Onde o tempo é a grande estrela/ Vejo o tempo obrar a sua arte/ [...]Modelando o artista ao seu feitio/ O tempo, com seu lápis impreciso/ Põe-lhe rugas ao redor da boca/ [...]O tempo arrebatalhe a garganta".

Ainda mais relevante é a estrofe final em que tempo e artista se confundem aparecendo como sujeitos do mesmo verbo: alcançar.

No anfiteatro, sob o céu de estrelas

Um concerto eu imagino

Onde, num relance, o tempo alcança a glória

E o artista o infinito

\footnotetext{
${ }^{5}$ Entrevista concedida a Augusto Massi em 09/01/1994.
} 
Em "Tempo e Artista" convivem duas concepções de tempo, a primeira ligada à existência humana, à vivência pessoal, à velhice e à morte, a segunda relacionada à percepção de permanência que a arte proporciona. Em meio à deterioração inevitável o ser humano deseja a perenidade que a arte é capaz de dar. Diante disso, na canção, o tempo alcança a glória e o artista alcança o infinito.

A tematização da transcendência, relacionada à compreensão de que a ação do tempo molda a arte e o artista, unindo-os na obra que recicla seu criador, intensifica-se no último álbum Chico, "mas o poeta não questiona a motivação poética da transcendência, evitando, assim, a angústia existencial do conflito" (SILVA, 2013, p. 75). Essa característica vai ao encontro da sutileza formal e temática das composições de Chico, onde a maturidade e equilíbrio do compositor colaboram para diversas reflexões serenas acerca do tempo, da história, do amor, da rotina. Observa-se, dessa forma, um trabalho de criação propositalmente em descompasso com o ritmo frenético e impessoal do mundo atual hipermoderno. Mesmo a aparente distração e sutileza das composições de Chico Buarque podem se tornar um fator de robustez nas mãos de um artista talentoso. De acordo com Chico:

Minhas músicas agora resultam de um tempo maior de meditação, de apuro. Todas são mais trabalhadas. E não só na composição, mas nos arranjos, no estúdio. É um trabalho mais sério, mais pensado. Ele e outros não saíram assim porque eu queria fazer música pretensiosa, refinada ou rebuscada de propósito. Acho que minhas músicas mais recentes são o resultado do amadurecimento. Talvez por isso quem sabe durem mais ${ }^{6}$.

Assim, a canção contém a expressão subjetiva do eu-lírico frente a uma realidade histórica da experiência existencial do sujeito que pode ser imediata ou não. $\mathrm{O}$ eu-lírico pode integrar na sua experiência lírica um segmento da realidade histórica ou ficcional, contemporâneo ou distante, local e temporalmente, da realidade atual do compositor. De fato, devido a um requisito da mimese poética, ele deve creditar a matéria elaborada em seus poemas às individualidades líricas concomitantes em tempo e espaço com sua real experiência existencial. Isso posto, as diversas apresentações da realidade referenciadas na expressão subjetiva do eu-lírico buarqueano são fragmentos do contexto histórico brasileiro que o artista busca através da sua memória subjetiva ou da memória poética do eu-lírico. Conforme Silva (2013, p. 76), as "proposições de

\footnotetext{
${ }^{6}$ Entrevista concedida à Revista Língua Portuguesa em 06/2006.
} 
realidade imediatas da experiência do eu-lírico sempre poderão ser referenciadas com outras, mescladas na expressão subjetiva do eu-lírico, inclusive com a imediata da experiência existencial do poeta".

Em Chico, considera-se a realidade histórica contemporânea, cuja referência se dá na instância discursiva do presente, que coincide com a experiência existencial do sujeito Chico Buarque. Em "Tipo um baião" essa característica se faz presente por meio do uso de registros linguísticos comuns na atualidade: "[...] você tipo me adora", "Igual que nem", "Diz que está tipo a fim", "Tipo assim num baião". Em "Nina" a referência à Internet ocorre através do lirismo de uma experiência existencial romântica: "Nina diz que se quiser eu posso ver na tela / A cidade, o bairro, a chaminé da casa dela”.

A “memória poética" é eixo fundamental de interpretação das canções presentes em Chico. Graças à hibridação poética que mistura as experiências líricas e romanescas na expressão subjetiva do eu-lírico, o artista pode valer-se da experiência existencial acessando livremente a sua memória poética. O título da primeira canção já introduz essa tendência: em "Querido diário" por traz da narrativa de acontecimentos cotidianos de "Hoje", existe certamente outras histórias já confessadas ao "querido diário". O acesso a essas experiências existenciais ajuda o sujeito a refletir sobre os novos acontecimentos.

Em "Barafunda" a hibridação discursiva da referenciação poética compõe a temática central da canção, inúmeras são as referências históricas e subjetivas que integram a confusão das lembranças e esquecimentos do eu-lírico. A última canção "Sinhá" reconstrói a memória poética através da contextualização lírica da realidade histórica de escravidão no Brasil e das memórias inerentes ao eu-lírico ("E assim vai se encerrar / O conto de um cantor / Com voz de pelourinho / E ares de senhor").

Tárik de Souza (1983) também foi outro crítico que analisou a obra de Chico Buarque, evidenciando a versatilidade do artista como um compositor que explorava variados ritmos e gêneros musicais. Característica essa mantida em seu último álbum onde encontramos além do tradicional samba de "Barafunda", a valsa em "Nina", o blues em "Essa pequena" e uma toada caipira em "Querido diário". A versatilidade também é reforçada pela escolha de ritmos musicais clássicos e regionais em letras cuja temática exploram questões de um sujeito em plena hipermodernidade: dos sons produzidos em computador, da alta tecnologia, velocidade e fluidez. 
Atrelado a isso podemos considerar a sua performance diferenciada, onde a obra se investe dos elementos performanciais que traduzem as relações intersubjetivas, envolvendo a representação e o vivido. Ganham destaque os elementos não textuais, as conjunturas e o ambiente cultural em meio à pessoa e ao jogo do intérprete.

Nesse sentido, a capa do álbum já é exemplar ao trazer uma foto em preto e branco de um Chico Buarque que sorri acanhado e apenas a palavra "Chico" sugerindo um modelo de simplicidade e melancolia que se faz presente, inclusive, em todas composições do seu último trabalho. No entanto, ao abrir o digipack, encontra-se uma variedade de cores que compõem o encarte com as letras das canções e nenhuma imagem. A simplicidade, desse modo, é o alicerce de vários elementos que compõem sua arte nesse álbum contemporâneo. O título Chico também contribui para a perspectiva de que as canções são de fato uma espécie de crônicas da vida do sujeito Chico Buarque imerso em um contexto social muito diverso daquele vivido pelo Chico das duas fases estabelecidas por Sant'Anna. Ocorre um "re-entry" 7 deslocado dele, por ele mesmo, num tempo diferente, um texto fora do contexto, trata-se de um discurso e uma reflexão do compositor acerca desse deslocamento com o uso de referências e alusões. Cabe ressaltar que a intenção proposta nesse estudo não é o levantamento completo e fiel da vida e obra do sujeito e artista Chico Buarque. Apesar disso, recorrer a alguns dos seus dados biográficos possibilitou compreender melhor o universo do cancioneiro buarqueano nos mais variados tempos do artista e, sobretudo, entender como a voz discursiva que carrega a experiência pessoal converte a pessoa na "persona" poética. Como explica Cyntrão (2004, p. 73):

[...] se por trás da obra literária está o homem, o ser, só se pode detectá-lo em sua dinâmica se o seu estudo abrange o contexto histórico em que se insere, a perspectiva diacrônica da obra produzida e a leitura poética, que permitirá, pela análise do simbólico estetizado, explicá-la em seu valor artístico.

Bakhtin (2003, p. 13) lança outro olhar quando diferencia o autor-pessoa, o artista, do autor-criado, aquele que preenche o objeto estético: "o autor deve colocar-se

\footnotetext{
${ }^{7}$ A expressão de Georg Spencer Brown é explicada por Mathis no seu artigo "A sociedade na teoria dos sistemas de Niklas Luhmann" enquanto: "Referências feitas em direção ao passado, isto é, algo que se mostrou como sentido, referem-se a operações contingentes, e não a origens fundamentadas. Da mesma forma, referências que visam o futuro, referem-se ao imenso do mundo virtual, no entanto sem saber se, e quais das possibilidades de observação o sistema, através das suas operações de observação introduz no sistema.” Disponível em <http://www.infoamerica.org/documentos_pdf/luhmann_05.pdf>.
} 
à margem de si, vivenciar a si mesmo não no plano em que efetivamente vivenciamos a nossa vida; só sob essa condição ele pode completar a si mesmo [...] deve tornar-se outro em relação a si mesmo, olhar para si mesmo com os olhos do outro".

Sobre esse aspecto, também deve-se considerar o conceito de "coro lírico", proposto por Silva (2010, p. 103-104), para definir os “sujeitos" representados em Chico:

O coro lírico é um objeto poético internamente construído pelas muitas vozes que contextualizam o social na lírica buarqueana, configurado na orquestração poética da polifonia vocal da sociedade brasileira. [...] Do diálogo intratextualizado dessas vozes com elas mesmas e com a voz poética que as recolhe no desvão das relações sociais resulta um coro lírico que se define, por si e em si mesmo, como recurso poético de representação do social na lírica buarqueana.

Isto posto, a lírica buarqueana não narra a trajetória individual do eu-lírico imerso na própria problemática, mas considera-o inserido na vivência compartilhada da problemática humano-existencial, ou seja, a voz poética é comprometida e solidária com as vozes do coro lírico. Essas vozes carregam subjetividades representativas dos mais variados grupos sociais e regionais (a voz religiosa, da mulher, do malandro, a voz lírica da MPB, a voz utópica, operária, etc.) e, quando imersas na tensão dialógica, traduzem a pluralidade vocal do povo brasileiro. Elas aparecem e reaparecem ao longo da obra de Chico, interligando as mais variadas representações do social aos ideais poéticos que caracterizam as etapas do projeto poético.

Ao avaliar todos os componentes de uma obra, Paul Zumthor (2007, p.18) compara a poética da escrita à poética da voz considerando que a segunda jamais deve ser econômica. Por isso mesmo, ele defende a difusão do conceito de performance enquanto parte do conjunto de ideias que compõem atualmente o conceito de recepção. Ele observa que nos mais novos estudos a concepção de performance tende a englobar toda uma espécie de teatralidade, marcada, sobretudo, por uma percepção sensorial ligada ao corpo. Ao considerar a literatura fundamentalmente teatro, esse estudioso das poéticas da voz, legitima a performance enquanto parte essencial do processo de análise literária.

Os estudos literários na atualidade consideram o leitor como um dos diversos elementos que constituem o texto. Podemos, então, inserir o conceito de corpo definido por Zumthor (2007, p. 23-24) como um elemento que torna palpável a história vivida, determinando a relação do sujeito com o mundo. 
Dotado de uma significação incomparável, ele existe à imagem de meu ser: é ele que eu vivo, possuo e sou, para o melhor e para o pior. Conjunto de tecidos e de órgãos, suporte da vida psíquica, sofrendo também as pressões do social, do institucional, do jurídico, os quais, sem dúvida, pervertem nele seu impulso primeiro. Eu me esforço, menos para apreendê-lo do que para escutá-lo, no nível do texto, da percepção cotidiana, ao som dos seus apetites, de suas penas e alegrias $[\ldots]$.

Chico Buarque, enquanto sujeito envolto nesse contexto, tem seu corpo representado na própria obra. Ao adentrarmos no simbólico presente nas letras das canções selecionadas, conheceremos "o corpo" como conceituado por Zumthor (2007, p. 23) - "o peso sentido na experiência que faço dos textos".

O exercício de leitura e análise de letras de canções vai além do simples ato da leitura em si, ação de decodificar um grafismo com o objetivo de obter uma informação. No caso da leitura de canções, soma-se à decodificação e à informação dados não informativos que estabelecem um elo pessoal entre o leitor e o texto. Tais elementos possuem a propriedade de proporcionar prazer ao leitor, sensação essa responsável por determinar a poeticidade/literariedade do texto. Observa-se, então, que é na forma de leitura praticada pelo sujeito que um discurso pode ou não tornar de fato realidade poética/literária. Trata-se de um texto compreendido e recebido como poético/literário o que estrapola o conceito geral de recepção do texto poético. Contudo, vale ressaltar que existem outros critérios de poeticidade ligados aos vários discursos presentes no meio social.

A proposta de introduzir a noção das percepções sensoriais nos estudos literários, defendida por Paul Zumthor, é de grande valor para essa pesquisa e deve ser considerada. Em um trabalho de análise literária, cujo corpus são letras poéticas de canções buarqueanas, faz-se necessário contemplar a voz e seus efeitos, seu caráter de emanação do corpo evidenciado sonoramente com plenitude. Para aplicá-la é necessário reaver conceitos moldados na nossa tradição, possibilitando o alargamento do seu campo de dados. Dessa forma, "um certo número de realidades e de valores, assim revelados, aparecem identicamente envolvidos na prática da leitura literária. Daí o lugar central que dou à ideia de "performance"” (ZUMTHOR, 2007, p. 27-28).

Esse trecho, que narra uma passagem marcante da infância de Paul Zumthor, traduz de maneira simples a ideia de "performance" como a única capaz de considerar a existência da forma, enquanto que os trabalhos que tomam a canção como instrumento 
de estudo, tendem a reduzi-la a análises e decomposições, desconsiderando o plano em que o discurso é vivido:

Havia o homem, o camelô, sua parlapatice, porque ele vendia as canções, apregoava e passava o chapéu; as folhas-volantes em bagunça num guarda-chuva emborcado na beira da calçada. Havia o grupo, o riso das meninas, sobretudo no fim da tarde, na hora em que as vendedoras saíam de suas lojas, a rua em volta, os barulhos do mundo e, por cima, o céu de Paris que, no começo do inverno, sob as nuvens de neve, se tornava violeta. Mais ou menos tudo isso fazia parte da canção. Era a canção. (ZUMTHOR, 2007, p. 28)

Observa-se que as regras da performance (envolvem o tempo, o lugar, a finalidade da transmissão, a ação do locutor e a resposta do público) têm tanta importância para a comunicação quanto o texto escrito pautado em regras préestabelecidas. Esse estudo literário considera a forma global da obra performatizada, mas, por força do foco no literário concentra-se no texto, cada um em seu momento devido. Com a atenção voltada para o fato social, o ponto de partida será a experiência pessoal, o prazer experimentado através do texto poético.

Levar em conta o conceito de performance pressupõe a necessidade de reincorporar a noção de corpo no estudo da obra literária. Zumthor (2007, p. 39), voltando a relatar a experiência vivida por meio da canção do ambulante, descreve assim a ligação entre o corpo e a poeticidade:

A canção do ambulante de minha adolescência implicava, por seus ritmos (os da melodia, da linguagem e do gesto), as pulsações de seu corpo, mas também do meu e de todos nós em volta. Implicava o batimento dessas vias concretas, em um momento dado; e durante alguns minutos esse batimento era comum, porque a canção o dirigia, submetia-o à sua ordem, a seu próprio ritmo. A canção tirava dessa tensão, portanto, uma formidável energia que, sem dúvida nem o pobre diabo do cantor nem eu, seguramente, aos doze anos, tínhamos consciência: a energia propriamente poética.

Observa-se daí uma densa convergência entre performance e canção, visto que ambas almejam à qualidade de rito. De fato, entender o discurso emanado nas letras poéticas contemporâneas de Chico considerando as características do tempo, do lugar e do sujeito hipermoderno não seria uma análise performática dessas canções?

De acordo com Silva (2010, p. 36), “o projeto poético buarqueano compreende as diversas poéticas que, modificando a concepção de poesia inerente ao processo criativo, delimitam seus diferentes estágios, atualizando o pensamento do poeta em relação ao ato criador e ao curso externo de sua lírica". Entendendo que a poética tem 
como proposta reformular uma concepção pessoal ou geracional de poesia e dar um novo rumo ao seu projeto de criação, pode-se refletir nessa pesquisa sobre uma nova poética do projeto poético buarqueano concebida em "Chico". Vale ressaltar que uma nova poética

[...] requer um período de maturação ao longo do qual o poeta vai se conscientizando do esgotamento dos procedimentos poéticos vigentes até convencer-se da inadequação desses princípios aos novos propósitos de sua criação, e um período posterior de exploração dos novos recursos, que se prolonga até a saturação de todo potencial criativo. (SILVA, 2010, p. 55)

Um "período de maturação" de cinco anos foram necessários para o lançamento do seu último álbum. Pensando na expectativa diante das novas canções, é de se supor o cuidado que Chico teve ao selecionar as dez faixas que, em pouco mais de meia hora de audição, revelam algo de registro biográfico, uma espécie de retrato musicado de um sujeito que adquiriu, após anos de experiência, a segurança para falar abertamente sobre seus próprios sentimentos e suas fragilidades mais humanas. Na verdade, são representadas inseguranças não só do eu-lírico, identificado em Chico Buarque no cotejamento com entrevistas gravadas, mas do sujeito contemporâneo imerso no contexto hipermoderno - mais uma vez podemos citar aqui o conceito de "re-entry" enquanto estratégia estética. O trecho a seguir da entrevista de Chico Buarque à Revista Brazucaonline (2010) é um exemplo da presença da experiência existencial na memória poética, sobretudo quando comparado à primeira estrofe da canção "Querido Diário" ("Hoje topei com alguns conhecidos meus/ Me dão bom-dia, cheios de carinho/ Dizem para eu ter muita luz, ficar com Deus/ Eles têm pena de eu viver sozinho"):

E fica essa coisa de Deus, que entra no vocabulário mais recente, que me incomoda um pouquinho. Essa coisa de "vai com Deus", "fica com Deus". Escuta, eu não posso ir com o diabo que me carregue? (risos). Tem até um samba que fala algo como "é Deus pra lá, Deus pra cá - e canta - Deus já está de saco cheio" (risos).

As letras mostram além de acontecimentos do cotidiano desse eu-lírico, referências cinematográficas, literárias e musicais.

A própria estratégia de divulgação online do álbum já demonstra a interação com os novos modelos globalizados e tecnológicos, onde, num esquema de pré-venda, os compradores tiveram acesso ao site com os bastidores dessa produção suave e delicada, contrastando com o caos e a velocidade dos novos tempos. Em entrevista disponibilizada para a imprensa via web, Chico revelou a maturidade das gravações do 
CD onde os takes foram feitos sem pressa e tudo pode ser ensaiado, visto e revisto, no tempo necessário.

Para compor o completo perfil do compositor, considera-se relevante observar a sequência e sua trajetória musical ligada às alterações políticas e sociais no Brasil a partir da segunda metade do século XX. Sabe-se que as transformações do país foram acompanhadas de perto pela música de Chico Buarque, principalmente quando temos como foco sua produção no contexto de redemocratização nacional. Da mesma forma, o fim do regime militar, em 1985, deixou um novo panorama para a canção popular produzida no país. Já a partir dos anos 1980, os produtores culturais começaram a procurar padrões da cultura internacionalizada que servissem como novos modelos para a produção cultural brasileira, visto que o fim da censura e o início do processo de redemocratização tornaram as canções de protesto obsoletas diante do desejo de “integração do povo" e construção de uma "identidade nacional".

O contexto histórico-político fica muito alterado, o mundo deixa a tradicional divisão bipolar entre duas grandes potências mundiais com ideologias diferentes, uma capitalista (os Estados Unidos) e outra socialista (a então União Soviética), dando origem ao fenômeno conhecido como "fim das ideologias". As letras "Roda-Viva"8 (1967) e "Cálice"9 (1973), em parceria com Gilberto Gil, por exemplo, tornaram-se símbolos de uma produção marcada pelos embates com a censura e os arbítrios do regime militar brasileiro e ajudam a explicar a trajetória de Chico, chegando até o álbum Chico em plena efervescência hipermoderna do ano de 2011, onde as ideologias tornaram-se difusas e não há mais um inimigo comum a ser combatido por meio das composições.

Algumas das principais imagens das letras mencionadas ("A gente quer ter voz ativa/ No nosso destino mandar/ Mas eis que chega a roda-viva/ E carrega o destino pra lá" - "Pai, afasta de mim esse cálice", "Quero cheirar fumaça de óleo diesel/

\footnotetext{
${ }^{8}$ Tem dias que a gente se sente/ Como quem partiu ou morreu/ A gente estancou de repente/ Ou foi o mundo então que cresceu/ A gente quer ter voz ativa/ No nosso destino mandar/ Mas eis que chega a roda-viva/ E carrega o destino pra lá/ Roda mundo, roda-gigante/ Rodamoinho, roda pião/ O tempo rodou num instante/ Nas voltas do meu coração.

${ }^{9}$ Pai, afasta de mim esse cálice/ De vinho tinto de sangue/ .../ Talvez o mundo não seja pequeno/ Nem seja a vida um fato consumado/ Quero inventar o meu próprio pecado/ Quero morrer do meu próprio veneno/ Quero perder de vez tua cabeça/ Minha cabeça perder teu juízo/ Quero cheirar fumaça de óleo diesel/ Me embriagar até que alguém me esqueça.
} 
Me embriagar até que alguém me esqueça”) evidenciam a importância histórica da canção como denunciadora de um poder que rechaçava determinados indivíduos no período de governo militar e como formadora da consciência crítica nacional diante da sua estrutura sócio-política.

A presença do "sonho", seja como utopia, devaneio, ou representações, também é marcante nas composições de Chico Buarque enquanto recurso de realização de um desejo. Durante essa fase de embate diante da repressão militar, Chico lutou contra o contexto político-social insatisfatório com as armas que possui e muito bem domina: a canção e o sonho.

A vida segue um movimento contínuo e circular que, paradoxalmente, paralisa o sujeito e a sociedade. Por outro lado, o "sonho" é intermitente, reforçando os paradoxos sociais. O sonho se converte em reflexo da vida, ambos se unem na experiência da angústia pessoal ou coletiva. Esse panorama deixa claro que as temáticas exploradas nas letras das canções levavam em consideração o contexto de desmandos e resistência desse momento histórico brasileiro. Ao longo dos tempos o homem também sofreu diversas transformações originárias do seu próprio imaginário. O descentramento do sujeito propiciou uma múltipla compreensão do indivíduo e da sociedade, possível de abarcar todas as divergências que compõem o todo social. Sendo assim, parte-se da ideia de que a literatura, enquanto produto do imaginário humano, é representativa e propagadora dos ideais e questionamentos do sujeito contemporâneo, apontando seus conflitos, suas multiplicidades, sua fragmentação e como idealiza sua identidade a partir da sua visão do Outro.

Sem a antiga força do rádio ou dos grandes festivais de televisão, Chico entregou-se aos recursos da Internet para promover e disseminar seu trabalho musical lançado em 2011. Tais mudanças dizem respeito à própria natureza da música popular brasileira - os temas, o modo de produção, a maneira como os artistas se apresentam. Ainda assim, no mundo atual da tecnocultura, que prioriza a comunicação pela linguagem, as conexões entre música popular e poesia literária permanecem revelando elementos históricos, sociais e literários. Por isso, o hibridismo das canções populares e a densidade simbólica das letras poéticas também operam como elementos de significação cultural e estética que ajudam o indivíduo hipermoderno no resgate da fragmentação e na procura pelo caminho para a integração e a inteireza. Enquanto um bem cultural de consumo, as canções adotam papéis de representantes das histórias e 
dos anseios que permeiam a sociedade que, em busca de novos paradigmas, tem descoberto na palavra poética e na melodia, juntas ou separadas, uma via de transformação e afirmação de suas angústias e questionamentos.

Diante desse modelo contemporâneo, vive-se numa época marcada pela desestruturação das culturas de classe, ou seja, não existem mais atributos que identifiquem uma classe específica, modos de vida exclusivos para determinado grupo social. Observa-se que num contexto de máxima diferenciação social, os modelos de bem-estar, moda e lazer, produzidos pelo mercado de consumo, dissipam-se em todos os níveis da sociedade. Surge, então, uma nova espécie de consumidor imprevisível, fragmentado e individualizado que transita por outros ambientes além da própria camada social. No entanto, esse processo de desregulamentação social e hiperindividualismo ligado ao consumo é um dos responsáveis pela escalada da decepção.

Por outro lado, Lipovetsky (2007, p. 53-55) é otimista ao afirmar que o mundo consumista não exerce seu poder sobre todas as dimensões do desejo humano. Uma ordem incita à obsessão pelo bem-estar e pelos prazeres "fáceis", enquanto outra, formada por pesquisadores, inventores, artistas, empreendedores, entre outros, está disposta a idealizar, a progredir e a superar: "O desejo de aprender e refletir, de atuar cada vez melhor, de sobrepujar os demais, nada disso foi erradicado e nem será futuramente, pois é 'induzido’ pela ordem democrática vigente, em cujo âmbito cada pessoa deve inventar sua vida e construir a sua identidade pessoal e social".

Discordando daqueles que creem na ruína da sociabilidade, devido ao individualismo consumista, à influência da mídia e aos avanços tecnológicos, o filósofo afirma que os sentimentos de empatia com o outro se tornam cada vez mais evidentes, sobretudo quando estamos diante de grandes catástrofes e das ações do voluntariado em favor dos mais carentes. A tendência natural do homem à sociabilidade não foi abalada pelas facilidades da Internet ou pelo apelo da televisão e do consumo; de fato ocorre justamente o oposto: a cada dia surgem novos formatos de relacionamento entre indivíduos e grupos sociais. Ainda que esses novos estilos de relacionamentos sejam tachados de frios e instáveis, Lipovetsky explica: "Por vezes, há mais intensidade e 'autenticidade' nas experiências passageiras, que não se consolidam na rotina diária. Por que insistir na tecla de que só aquilo que é durável está livre da frivolidade e da superficialidade?". Esse ponto de vista é representado nas letras poéticas buarqueanas: 


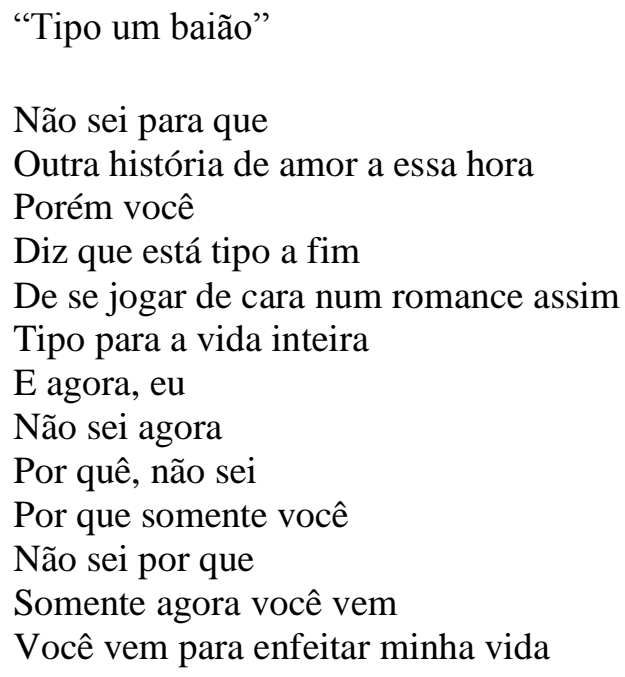

\section{"Sem você 2"}

Sem você

É o fim do show

Tudo está claro, é tudo tão real

As suas músicas você levou

Mas não faz mal

\section{"Essa pequena"}

Meu tempo é curto, o tempo dela sobra

Meu cabelo é cinza, o dela é cor de abóbora

Temo que não dure muito a nossa novela, mas

Eu sou tão feliz com ela

Ao mesmo tempo em que a sociedade hiperindividualista deixa os sujeitos confusos diante de tantas opções, ela os redime na medida em que fornece variadas oportunidades de orientação e novos desafios. A esperança de futuro aumenta ao passo que cresce a oferta da felicidade disseminada por meio do consumismo. No entanto, se a época hipermoderna oferece múltiplos caminhos para a conquista da felicidade e aumenta a esperança, junto com ela vêm ilusões e decepções.

Nesses casos, a valorização do que é duradouro revela principalmente o medo da solidão e o desejo da segurança afetiva. A duração de um relacionamento acaba não garantindo uma perfeita comunicação entre os pares, pelo contrário: a longa rotina faz sobrevir o tédio, a irritação e o cansaço. $\mathrm{O}$ duradouro pode não ser necessariamente o ideal, pois depende da maneira como ele é vivido. 
Nesse contexto, aqueles que perderam o interesse pela política agora colocam suas expectativas em outras demandas como a educação, a proteção do meio ambiente, o amor:

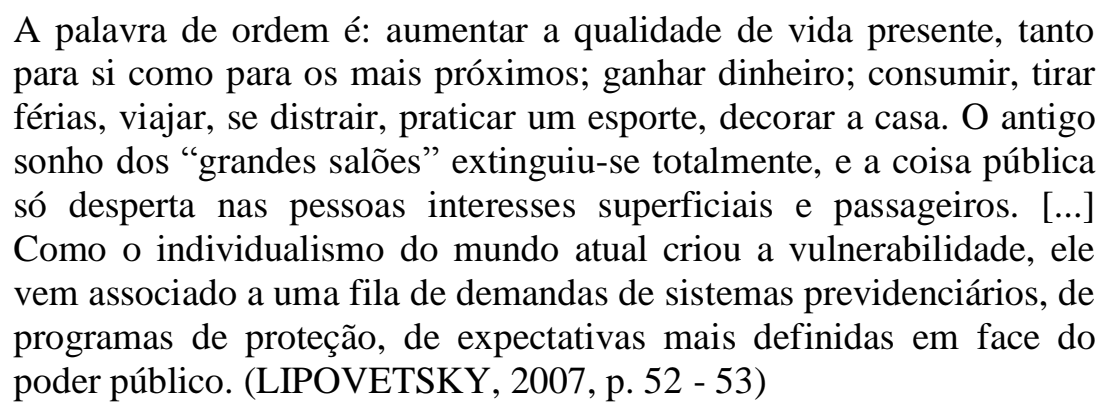

Chico Buarque também segue essa tendência compondo, em plena confusão hipermoderna, letras que apresentam uma desconcertante simplicidade temática, da qual o título do álbum, Chico, também é representativo e que por si só configura-se num complexo paradoxo contemporâneo. O capítulo seguinte demonstrará o tom de nostalgia desse trabalho artístico em meio à velocidade dos novos tempos de desorientação e relações fluídas. Observaremos a reentrada de valores selecionados do passado: o "reentry, ora mais atual ora mais distante, que é um posicionamento do compositor perante a hipermodernidade e, ao mesmo tempo, a hipermodernidade que o constrói.

Para atingir o sentido desse discurso, considerando as intenções daquele que fala, é necessário uma intervenção corporal que ajude a vencer a resistência das palavras. Essa ação se dá por meio de uma operação vocal: uma voz pronunciada e ouvida ou a voz imperceptível de uma articulação interior. Atualmente, a generalização da ideia de performance é resultado dessa relação: o discurso que o sujeito faz sobre qualquer perspectiva do mundo estabelece no outro um corpo-a-corpo com o mundo. "O mundo me toca, eu sou tocado por ele; ação dupla, reversível, igualmente válida nos dois sentidos". No caso da semântica poética esse vínculo é fundamental: "em uma semântica que abarca o mundo [...], o corpo é ao mesmo tempo o ponto de partida, o ponto de origem e o referente do discurso. O corpo dá a medida e as dimensões do mundo" (ZUMTHOR, 2007, p. 77).

O texto poético significa o mundo. Ele desperta no leitor uma consciência confusa de estar no mundo que é anterior a qualquer referência ou ideal, "como uma impureza sobrecarregando o pensamento puro". Mais do que elemento de um discurso informativo, o mundo aqui invade a ordem do sensível: "Daí o prazer poético, que provém, em suma, da constatação dessa falta de firmeza do pensamento puro", e que 
também se faz presente no estudo da canção. Por essa razão que, no texto poético, o sentido inferido pelo leitor não pode ser limitado à decodificação de signos passíveis de análise. Ao contrário, aí o sentido "provém de um processo indecomponível em movimentos particulares" (ZUMTHOR, 2007, p. 78-79).

Os sujeitos isolados em suas próprias experiências têm a possibilidade, por meio da intenção poética e sua intervenção no processamento da realidade objetiva, de vivenciar uma experiência humana compartilhada baseada em valores intrínsecos do ser humano. Assim compreendida, a poesia "constitui um instrumento mágico capaz de neutralizar o processo de diferenciação do cotidiano e redimensionar a experiência humana de ser e estar no mundo". O poeta, por sua vez, sugere compartilhar o seu canto, na tentativa de que todos possam, graças ao efeito da magia poética, refletir sobre a sua problemática pessoal diária em meio à experiência lírica integradora (SILVA, 2013, p.47-48). Essa concepção poética que delega à poesia a tarefa de estabelecer novas proporções às experiências existenciais do cotidiano dos oprimidos, solitários, tristes, desiludidos, e convida a compartilhar da experiência lírica, se fazem presente nas canções do primeiro álbum de Chico por meio de variados recursos poéticos. "A banda" (1966) é um exemplo de como a passagem da banda, e com ela o fluxo da intervenção poética, vai alastrando o redimensionamento da realidade até ocupar todo o terreno da experiência cotidiana antes tomado pela dor e tristeza:
A minha gente sofrida
Despediu-se da dor
Pra ver a banda passar
Cantando coisas de amor
O homem sério que contava dinheiro parou
$\mathrm{O}$ faroleiro que contava vantagem parou
A namorada que contava as estrelas parou
Para ver, ouvir e dar passagem
A moça triste que vivia calada sorriu
A rosa triste que vivia fechada se abriu
E a meninada toda se assanhou
Pra ver a banda passar
Cantando coisas de amor

Foi observado que Chico Buarque reflete sobre a matéria histórica, social e política do Brasil contextualizada desde a década de 1960, época da sua estreia na MPB, até os dias de hoje. As lembranças memoráveis da experiência existencial de Chico são um "memorial lírico da realidade brasileira e do mundo" que, reinterpretadas e transformadas possibilitam o avanço do projeto poético do artista, contribuindo para o 
legado de sua obra: "A atividade da memória consiste em destruir, reinterpretar e transformar contextos, imagens e palavras do passado, para inaugurar um novo tempo no presente, sinalizando um novo começo pessoal e coletivo para a construção do futuro desejado" (SILVA, 2013, p. 88). 


\section{OS TEMPOS “HIPER” NAS CANÇÕES DE CHICO (2011)}

Os temas abordados nas letras contemporâneas de Chico Buarque são resultado do histórico de sua obra imerso no contexto das "três ondas de descontinuidade" propostas por Lipovetsky e Serroy (2011). Uma das hipóteses desse estudo é que através da leitura das letras do compositor seria possível traçar o perfil da história nos últimos 50 anos. Desse modo, todo tema possui vestígios dos temas precedentes e subsequentes, o que lhe confere uma identidade histórica no interior da obra: "ele é um pouco do que já foi e um pouco do que será” (TATIT, 2004, p. 182).

Seguindo o panorama contemporâneo, onde a palavra de ordem é reciclar e reintegrar referenciais do passado de acordo com a lógica hipermoderna, o artista passa por um processo de reciclagem, enquanto sujeito atuante imerso em seu tempo, e de atualização da sua concepção artística, até chegar ao último álbum Chico. Essa renovação reforça o caráter híbrido dos recursos e das formas artísticas que fazem da lírica buarqueana uma manifestação legítima da poética atual. A canção de Chico Buarque faz da hibridação o impulso semiótico dos mecanismos poéticos usados para a criação de efeitos de sentido, sobretudo por meio do diálogo íntimo com sua própria obra e com a produção de artistas do presente e do passado, somado à mistura de diferentes contextos históricos e referenciais míticos - conforme será visto através da referência à personalidades da MPB na alusão à Gonzaga em "Tipo um baião", da citação de lendas e tradições populares como o futebol e o carnaval em "Barafunda" e dos modelos religiosos presentes em "Querido Diário" e "Sinhá". Segundo Charles (2009), a arte moldou-se à dinâmica hipermoderna e assegurou uma complementação da existência, um prazer de viver e de sentir, valorizando o conforto e considerando as expectativas do seu público. Por outro lado, descartou obras complexas cujo significado esteja disponível apenas por intermédio de explicações abstratas, que pressuponham um entendimento profundo do trabalho do artista.

Sendo assim, nada impede os artistas hipermodernos de:

[...] reencontrar o sentido do universalismo, de cultivar o gosto pelo esforço e pelo trabalho em substituição ao discurso baseado exclusivamente na inspiração e na espontaneidade, de preferir a inteligibilidade dos seus trabalhos em detrimento das facilidades do mistério, a clareza da obra em vez dos inúmeros discursos supostamente justificadores da sua complexidade, e de se preocupar mais em tocar os seus contemporâneos do que em esperar um hipotético reconhecimento da posteridade. (CHARLES, 2009, p. 123) 
Artistas como Chico Buarque escolheram percorrer esse caminho “[...] rompendo com a divinização da arte ao submetê-la à vida em vez de colocar a vida a serviço da arte" (CHARLES, 2009, p. 124-125).

Por meio da análise das letras selecionadas, surgem manifestações em tom nostálgico, representativas do imaginário dos sujeitos, em oposição direta à realidade da sociedade globalizada, movida pelos mais variados avanços tecnológicos e cuja racionalidade institucional contém qualquer manifestação individual.

O "culto do presente" vai reforçar a disposição à introversão, marca dos tempos "hiper". Vê-se no plano artístico, nesse caso, na canção, o lugar da busca de uma unidade pessoal, de retorno à espontaneidade do sensível, por meio da escolha da paixão e da imaginação em detrimento da razão e da "realidade".

Uma das maiores e mais observadas consequências desse regime presentista é a atmosfera de pressão que ele faz pesar sobre a vida das organizações e das pessoas, visto o ritmo frenético que impera nas empresas em uma época de concorrência globalizada e ditames financeiros, além das constantes exigências de resultados a curto prazo, fazer mais no menor tempo possível, agir sem demora. Compõe-se um quadro paradoxal onde a corrida da competição prioriza o urgente, o imediatismo e o acessório em detrimento do que é de fato importante, da reflexão e do essencial. O reinado hipermoderno da urgência institui, desse modo, um clima de dramatização e de estresse sem precedentes.

A nova ordem do tempo não atinge somente o universo do trabalho, mas, sobretudo a relação do indivíduo com seu próprio cotidiano e com o outro. São múltiplas tarefas em um tempo que se esvai: quanto mais depressa se vai, menos tempo se tem. Eis a principal queixa do sujeito hiper, a falta de tempo.

A descrição e interpretação de determinada circunstância psíquica e individual nas letras das canções estão marcadas, constantemente, pela tendência ao abandono. $\mathrm{O}$ que nos leva a observar a dimensão coletiva da problemática na qual estamos inseridos e o caráter preponderante da canção no sentido de atuar como um meio que, ao atrelar diversão e conhecimento, leva ao "sujeito comum" elementos para entender o Outro, o mundo em efervescente mutação em que ele está inserido: 
No plano do conteúdo da letra, a identidade se expressa por acordos e encontros entre personagens ou por conjunções entre eles. Um personagem pode ser entendido como o resultado de conquistas já obtidas e de esperanças de novas aquisições. Por essa necessidade de completude - ou seja, de integrar-se com seus semelhantes e com as coisas do mundo - ele vincula-se ao passado e ao futuro e se consolida como ser em transição. Mas como esse ser jamais atinge a perfeição (a completude), o sujeito também se define por uma insuficiência contínua: já não possui mais tudo o que possui outrora e ainda não possui tudo o que gostaria de possuir no futuro. Se, de um lado, esse sentimento de falta fratura sua identidade, de outro, devolve-lhe a noção de alteridade: o sujeito precisa do "outro" para se completar. (TATIT, 2004, p. 183)

Nota-se um sujeito que necessita do "outro" para estruturar a própria identidade. Essa busca repercute na letra por meio de desencontros amorosos e de disjunções entre personagens. Conforme Adorno (1962, p. 54), “o conteúdo de um poema não é apenas a expressão de emoções e experiências individuais". Baudelaire (1972) vai além dizendo que o poeta desfruta do privilégio de ser ao mesmo tempo ele próprio e o Outro. O poeta é aquele que tem a maior possibilidade de contato com o próprio inconsciente. Por sua vez, a poesia é um espaço no qual se admite ao inconsciente aflorar. A produção musical de Chico Buarque segue esses conceitos dando voz, ao longo de sua trajetória, a diversos segmentos temáticos: amantes, mulheres, desvalidos, perseguidos... Esses diversos "Chicos" resultaram no Chico Buarque maduro e sereno presente nas letras do álbum Chico.

Segundo Hall (2005), uma das consequências da globalização sobre as identidades culturais é o surgimento de novas identidades híbridas em detrimento das enfraquecidas identidades nacionais cada vez mais expostas às influências externas e à infiltração cultural.

Imerso nesse cenário, o cancioneiro buarqueano, enquanto representante legítimo do projeto poético brasileiro, transita por essa atmosfera de variados e abrangentes discursos. Os diferentes tempos e a mobilidade de sua produção demonstram que as identidades dos sujeitos seguem inacabadas, adaptando-se de acordo com a forma como o indivíduo é interpelado ou representado.

Como dito anteriormente, investiga como o imaginário coletivo é representado nos dias de hoje a partir do simbólico presente nas letras do álbum Chico, observando o fenômeno da cultura-mundo e seus paradoxos relacionados à erosão das fronteiras e à compressão do espaço-tempo em oposição ao fenômeno de defesa das identidades 
culturais e linguísticas. Cabe ressaltar que as interpretações das canções revelam um primeiro olhar sobre essa recente obra, objeto de outros poucos e iniciais estudos analíticos. Compostas por elementos melódicos, linguísticos e entoativos, as canções aqui analisadas serão elementos de uma reflexão cuja perspectiva é metonímica. Em outras palavras, a letra como um sistema semiológico autônomo representando a canção, como gênero híbrido que é.

Nesse sentido, observaremos nas letras poéticas de Chico Buarque um olhar voltado para o ser social e cultural, mobilizando diversas formas de intertextualidade já que "todo o texto é absorção e transformação de um outro texto", responsável por fornecer importante perspectiva para uma abordagem literária (KRISTEVA, 1974, p. 64).

Zumthor (2007, p. 67) complementa:

A leitura literária não cessa de trapacear a leitura. Ao ato de ler integra-se um desejo de restabelecer a unidade da performance, essa unidade perdida para nós, de restituir a plenitude - por um exercício pessoal, a postura, o ritmo respiratório, pela imaginação. Esse esforço espontâneo, em vista da reconstituição da unidade, é inseparável da procura do prazer.

Pela voz ou pela escrita, a obra, quando transmitida ao público, produz uma infinidade de encontros, tão distintos quanto os vários ouvintes e leitores. No entanto, quando a comunicação se dá pela oralidade, a recepção é coletiva. O cantar em público tem como intuito provocar um movimento de multidão com o benefício de recursos retóricos, rítmicos, musicais capazes de considerar sensibilidades individuais diversas: "Em todos os horizontes se esboçam os movimentos de uma desalienação, a longo prazo, da palavra humana; movimentos que, de crise em crise, não cessam de superar os contrários" (ZUMTHOR, 2007, p. 55). Em plena era tecnológica vive-se a expectativa de que o modelo de uma impetuosa sociedade de consumo será imposto à sociedade em detrimento das outras formas de cultura que serão devidamente reprimidas.

O consumismo do nosso tempo é alimentado tanto pela angústia existencial quanto pelo prazer associado às mudanças. Esse é o desejo global do consumidor hipermoderno: intensificar o cotidiano, renovar sua vivência do tempo através das novidades que se oferecem como simulacros de aventura. O hiperconsumo carrega consigo a negação ao tempo exaurido e repetitivo, o conflito diante do envelhecimento das sensações que acompanha a rotina diária. É o desejo de eterna renovação do eu e do presente que define o sujeito hiper. Em meio ao hiperconsumo, enquanto receita de 
rejuvenescimento que se reinicia eternamente, preocupa-nos menos a ameaça da morte e da finitude do que a angustiante possibilidade de estagnarmos em nossas vidas.

No entanto, frente à proximidade dessa ameaça, cresce também as manifestações de resistência em várias áreas da vida social. Na publicidade, nas artes, na poesia, resistem as "formas de expressão corporal dinamizadas pela voz" (ZUMTHOR, 2007, p. 62). A canção também é considerada nesse trabalho enquanto forma de reação ao modelo de consumo. Zumthor (2007, p. 63) apoia essa teoria quando afirma estarmos vivendo o prelúdio de uma "nova era da oralidade" onde a voz, inserida em determinada cultura, é agente impulsor da energia coletiva. A partir dessa reintrodução da voz na estrutura do corpo social, pode-se considerar a redenção "a despeito das recuperações e das comercializações inevitáveis, o retorno do homem concreto".

De acordo com o autor:

[...] em situação de oralidade pura, se mantém, de momento a momento, uma unidade muito forte, da ordem da recepção. Todas as funções desta (ouvido, vista, tato...), a intelecção, a emoção se acham misturadas simultaneamente em jogo, de maneira dramática, que vem da presença comum do emissor da voz e do receptor auditivo, no seio de um complexo sociológico e circunstancial único. (ZUMTHOR, 2007, p. 66-67)

As análises terão início, portanto, com a canção "Querido diário" que serviu de primeira inspiração para o desenvolvimento dessas reflexões sobre a obra musical mais recente do compositor.

Hoje topei com alguns conhecidos meus

Me dão bom-dia, cheios de carinho

Dizem para eu ter muita luz, ficar com Deus

Eles têm pena de eu viver sozinho

Hoje a cidade acordou toda em contramão Homens com raiva, buzinas, sirenes, estardalhaço

De volta a casa, na rua recolhi um cão

Que de hora em hora me arranca um pedaço

Hoje pensei em ter religião

De alguma ovelha, talvez, fazer sacrifício

Por uma estátua ter adoração

Amar uma mulher sem orifício

Hoje afinal conheci o amor

E era o amor uma obscura trama

Não bato nela nem como uma flor

Mas se ela chora, desejo me inflama

Hoje o inimigo veio me espreitar 
Armou tocaia lá na curva do rio

Trouxe um porrete a mó de me quebrar

Mas eu não quebro porque sou macio, viu

Observa-se que a letra é povoada pelas diversas temáticas envolvidas no turbulento contexto hipermoderno tão bem descrito por Lipovetsky: a solidão, os relacionamentos, a traição, a confusão e pressa das grandes cidades, os ideais religiosos em meio à falta de referenciais do passado, o amor, entre outros. $\mathrm{O}$ eu poético narra os acontecimentos do seu "Hoje", registro linguístico comum nos diários que ganha ênfase ao ser repetido nos primeiros versos de cada uma das cinco estrofes da canção e que serve "como suporte de configuração rápida das lembranças memoráveis do poeta, guardadas na memória poética da lírica buarqueana" (SILVA, 2013, p. 78).

A letra poética pode ser dividida em cinco registros autônomos, cada estrofe representa um contexto da vida do eu-lírico. O primeiro apresenta a relação do sujeito poético com a comunidade próxima: "os conhecidos". O segundo revela uma imagem da sociedade contemporânea: o espaço e comportamento social. O terceiro está relacionado ao contexto de fala da transcendência, observa-se o conceito de elevação espiritual por meio da sublimação da relação amorosa. O quarto aborda a "obscura trama" do amor. E o quinto sobre o comportamento do eu-lírico frente às adversidades atuais.

No momento em que as confissões feitas ao "querido diário" se tornam abertas, o eu-lírico revela a intenção de compartilhar com o público suas memórias que também se cruzam com as do compositor, conforme trechos de algumas entrevistas de Chico Buarque sobre os mais diversos temas. Estabelece-se assim o "re-entry" na vida hipermoderna enquanto estratégia estética.

Logo na primeira estrofe nos é apresentado o eu-lírico que apesar dos contatos passageiros com "conhecidos" revela "viver sozinho". Essa é uma imagem típica da contemporaneidade onde os indivíduos vivem relacionamentos cada vez mais fluídos, fugindo dos vínculos que levam ao risco da decepção diante do rompimento. Ao mesmo tempo, a exasperação da postura narcísica impossibilita a intimidade e estabelece um trânsito de mão única, ou seja, uma representação da contramão do próprio sujeito, que investe o mínimo nas relações. As trocas intersubjetivas ficam prejudicadas uma vez que o isolamento do eu descarta a relação com o outro, ou seja, desconsidera a “contramão". 
Esse sentimento de solidão, frequente na sociedade hipermoderna, está ligado à individualização dos modelos de vida, ao enfraquecimento dos vínculos coletivos e ao esvaziamento das instituições familiares e religiosas. Hoje o dever de ser útil, funcional, parte da grande engrenagem do mundo, se tornou uma espécie de direito. Ser uma peça inserida na "máquina do mundo" nos torna fortes. É preciso assumir uma utilidade, cumprir com alguma função, inserir-se. Por outro lado, estar excluído dessa engrenagem é "ser ninguém", seguir sem uso, obsoleto e ser descartado.

Nos versos dessa letra encontramos a voz de um homem solitário, de certa forma um ermitão, que vive os fatos narrados num diálogo com seu "querido diário", um objeto representativo do universo feminino. Vemos na obra a tendência à descaracterização por meio da mistura dos ícones sociais representantes dos gêneros masculino e feminino. Tendência essa também apontada pela sociedade hipermoderna que busca libertar-se dos estereótipos relacionados ao comportamento dos gêneros, visto que o vazio criado pela dinâmica da individualização e pelo refluxo dos grandes ideais político-ideológicos provocaram a necessidade de assimilação diante das comunidades étnicas, religiosas ou regionais particulares. Se de um lado temos o "diário" como símbolo do mundo feminino, de outro temos a imagem do "porrete" como uma metáfora masculina representativa do "inimigo", da violência ("[o inimigo] Trouxe um porrete a mó de me quebrar/ Mas eu não quebro porque sou macio, viu"). Nesse momento um outro estereótipo é desfeito, vindo na contramão e atropelando a expectativa do leitor ou ouvinte: o eu-lírico não "quebra" pois é "macio". Em oposição a rudeza e a violência vinculadas à imagem do homem, o eu lírico, reconhecidamente masculino ("sou macio"), utiliza-se de uma metáfora do feminino para safar-se do perigo.

Ainda é interessante observar que a segunda estrofe apresenta a figura de um cão que pode ser relacionada ao argumento de Lipovetsky quando trata do apego aos animais de estimação no mundo contemporâneo: "De volta a casa, na rua recolhi um cão / Que de hora em hora me arranca um pedaço". Nessa estrofe o sujeito apresenta um olhar voltado para a Cidade, sua pressa, confusão, frieza. O cão toma conta da vida do eu-lírico já que todo o sentimento que ele não recebe dos "conhecidos" (nota-se que ele não diz "amigos") é introjetado por meio da presença do cão apanhado das ruas. Um "pedaço" da ternura contida no sujeito é "arrancado" pela figura do cão, o seu único companheiro. 
A metáfora em "Amar uma mulher sem orifício" pode fazer referência a uma mulher passiva, que não fala, tampouco se sobressai diante da figura masculina que tem o controle da relação. Após mencionar a necessidade de "ter religião" e a figura da "estátua" pela qual teria adoração, podemos pensar que a "mulher sem orifício" é a Virgem Maria que concebeu seu filho, Jesus, sem pecado. Outra possível interpretação é a da mulher que apenas ama, sem o ideal carnal que, sobretudo em tempos hiper, acompanha o relacionamento amoroso. Vemos que o eu poético parece querer retomar comportamentos e ideais do passado que estão em total descrédito nos dias hipermodernos:

\author{
Hoje pensei em ter religião \\ De alguma ovelha, talvez, fazer sacrifício \\ Por uma estátua ter adoração \\ Amar uma mulher sem orifício
}

No passado do ocidente, a vida estava intimamente ligada a um significado cristão; toda a existência era passível de uma regulação com base nesses preceitos; facilitado pelo ordenamento religioso. A modernidade, por sua vez, estabelece o ideal de uma salvação coletiva a ser conquistada.

No século XXI, a lógica tem apontado para viver o máximo possível e o mais intensamente possível. A existência resume-se em uma simples experiência. Entretanto, o sujeito hipermoderno carece dos alicerces espirituais e religiosos para enfrentar as asperezas e desilusões do seu tempo. Em uma entrevista de 2010, Chico revelou: "Eu não tenho crença. Eu fui criado na Igreja Católica, fui educado em colégio de padre. Eu simplesmente perdi a fé. Mas não faço disso uma bandeira. Eu sou ateu como o meu tipo sanguíneo é esse". Entretanto, ele afirmou: "Hoje há uma volta de certos valores religiosos muito forte, acho que no mundo inteiro", indicando a mesma tendência que persegue o eu-lírico da letra: "Hoje pensei em ter religião".

Quanto maior a autonomia dos indivíduos, quanto maior a sua libertação, maiores são os riscos. Nesse sentido, o verso "Por uma estátua ter adoração", recorda o mito do escultor grego Pigmaleão, apaixonado pela própria obra. Em tempos hiper, a imagem de Pigmaleão representa a falta de referentes, de modelos de comportamento que deixam o sujeito perdido e angustiado frente à enorme oferta de padrões da culturamundo.

Em suas composições Chico usa da hibridação textual e contextual, além do diálogo interiorizado com a própria obra, compondo o perfil contemporâneo da lírica 
buarqueana. O trovador de "Querido Diário" é um típico sujeito contemporâneo oscilando entre o arcaico e o moderno, constatando a caótica urbanidade em que está imerso ("Hoje a cidade acordou toda em contramão/ Homens com raiva, buzinas, sirenes, estardalhaço").

Os espaços, desordenados e sem planejamento, tornam-se fragmentados, conforme a lógica do capitalismo tardio, que se expressa por meio de prédios cada vez mais altos e mais próximos uns dos outros, bem como das publicidades que sem ordenamento se multiplicam, tumultuando a paisagem. Fragmentação pode ser então entendida como um conceito chave para a análise do que poderíamos denominar de viver nas hipercidades, numa lógica da hipermodernidade. Como explica Da Matta (1997 p. 30) “o espaço se confunde com a própria ordem social de modo que, sem entender a sociedade com suas redes de relações sociais e valores, não se pode interpretar como o espaço é concebido". Desse modo, essa inter-relação entre espaço, sociedade, redes de relações e valores sociais e culturais reflete nas relações sociais.

Até mesmo a melodia é vítima desse modelo paradoxal quando a sofisticação melódica do início da canção dá lugar, já na segunda estrofe, ao singelo ritmo violeiro caipira. A canção ganha um quê de toada sertaneja, rural, em clara oposição com a "cidade toda em contramão". Ao mesmo tempo observa-se o uso da linguagem informal, popular, como o verbo "topar", muito característico do cotidiano, ao invés de "encontrei" (Hoje topei com alguns conhecidos meus").

A descoberta do amor possibilita ao eu-lírico abandonar sua complexa e pedante observação do mundo, suas angústias e problemáticas (Deus, o trânsito, o cão), tornando-se parte dele. Apesar de todas as dúvidas, o amor faz com que ele abandone a frieza e a distância característica de um observador, expondo seus desejos. Ainda assim, o sentimento amoroso é visto como "uma obscura trama", visto que esse sentimento em qualquer época e lugar sempre terá algo de intrigante, indecifrável:

As imagens míticas do amor constituem inscrições simbólicas na cultura e nela circulam permeadas por fatores tais como força de representação da problemática humano-existencial, aceitação do grupo social em que circulam, injunções sociopolíticas relacionadas aos canais de sua circulação, entre outros. A representação literária, por sua vez, conjuga, de diferentes modos, o prazer estético e o papel social, em obras nas quais se reconhecem as transformações das relações pessoais. É possível por essa via investigar os deslizamentos de sentido que o amor sofre na difícil integração do desejo dos indivíduos na ordem social. (CYNTRÃO, 2013, p. 364) 
Nota-se que o desejo surge do choro "dela". Em mais uma imagem em oposição, desejo e gozo estão em choque:

Hoje afinal conheci o amor

E era o amor uma obscura trama

Não bato nela nem como uma flor

Mas se ela chora, desejo me inflama

Desta vez, o eu-lírico tem um inimigo oculto, que "Armou tocaia lá na curva do rio/ Trouxe um porrete a mó de me quebrar”. Evidencia-se novamente nesse diário de um homem comum o imaginário sertanejo presente na literatura regionalista. Mas ele consegue livrar-se da "tocaia" porque é "macio", flexível. O sujeito revela que sabe viver as contradições e se adequar.

Nessa letra, Chico Buarque produz uma singular metalinguagem, já que em uma entrevista concedia a Revista Trip em 2006 o artista já dava pistas sobre seu sentimento diante da crítica da imprensa que, segundo ele, o incomodava com "muita porrada" e que sentia como se algo o espreitasse "a cada esquina" mas com o tempo foi ficando "mais calejado", ou mais "macio", conforme a letra. Nota-se a similaridade com os acontecimentos vividos pelo eu-lírico de "Querido diário": "Hoje o inimigo veio me espreitar/ Armou tocaia lá na curva do rio".

Nos anos 80 foi barra-pesada. Você cansa, né? Tomando muita porrada, você vai perdendo a vontade de se expor a mais porrada. Eu tinha de ler o Jornal do Brasil com capacete, porque tinha porrada em tudo que era seção. Até a seção de gastronomia dava porrada. A Folha de S. Paulo, numa época, também era uma coisa barra-pesada. Isso, durante uns dez anos, foi muito chato. Principalmente uma certa imprensa paulista muito, muito agressiva. Depois melhorou um pouco. Hoje, não sei. Às vezes tenho a intuição de que algo está se armando [risos], que estão ali atrás, na esquina, espiando, "ele vai passar agora", prontos para dar porrada. Mas as porradas também com o tempo vão doendo menos, você vai ficando um pouco mais calejado.

A pretexto de uma luta simbólica vivida pelo solitário eu-lírico, presente num primeiro nível de significação, o autor mostra enfrentar sua guerra particular contra os entraves da própria obra: a crítica, o tempo, a realidade, os caprichos da arte. Confirmando seu compromisso com o futuro e com as exigências estéticas impostas, porque é "macio, viu?!".

A temática do amor também é recorrente na obra, manifestando-se por meio de profundo lirismo e, por vezes, de forte dramaticidade. Ela ocorre, sobretudo, na letra poética onde o sujeito é marcado por uma inquietação que nasce da sua relação com o 
mundo. Observa-se um constante olhar sobre o passado, um sentimento saudosista de que algo se perde frente ao inabalável embate entre a realidade e o sonho, entre o presente e um passado idealizado, temas sempre presentes nas canções de Chico Buarque e que revelam viver-se na "época da ansiedade".

A riqueza das situações de amor cantadas por Chico Buarque transita pelo ideal romântico e chega à estética contemporânea, se fazendo presente em variados tons, incorporados por eu-líricos masculinos e femininos. Telles (2013, p. 172) considera Chico exemplar "na maestria em reunir, em sua dicção poético-musical, a delicadeza do mundo subjetivo, do universo amoroso-existencial, a tudo o que faz parte da concretude da vida, dos elementos mais simples do dia a dia de pessoas comuns". Segundo o autor, "a fala brasileira do cotidiano alimenta a construção de imagens de grande força num cancioneiro que, aliando simplicidade e sofisticação, alcança ouvidos e sentimentos heterogêneos".

O blues "Essa Pequena" introduz a paixão de um homem por uma moça mais nova e os contrastes entre gerações. Nota-se o embate entre o tempo, característica comum na hipermodernidade onde a diluição das fronteiras resulta no imediatismo.

Meu tempo é curto, o tempo dela sobra Meu cabelo é cinza, o dela é cor de abóbora Temo que não dure muito a nossa novela, mas Eu sou tão feliz com ela

Meu dia voa e ela não acorda

Vou até a esquina, ela quer ir para a Flórida

Acho que nem sei direito o que é que ela fala, mas

Não canso de contemplá-la

Feito avarento, conto os meus minutos

Cada segundo que se esvai

Cuidando dela, que anda noutro mundo

Ela que esbanja suas horas ao vento, ai

Às vezes ela pinta a boca e sai

Fique à vontade, eu digo, take your time

Sinto que ainda vou penar com essa pequena, mas

O blues já valeu a pena

Toda a letra é calcada nas diferenças entre o par amoroso: ele, mais velho, sente que o tempo se esvai, por isso como um "avarento" conta os minutos. Ele teme a morte e, consequentemente, teme perder a amada. Por sua vez, a jovem "esbanja" o tempo que demora a passar. 
O eu-lírico, maduro, de "cabelo cinza", vive o "amor contemplação". Entende esse romance como uma "novela" com data para o capítulo derradeiro, mas sente-se feliz e, de fato, esse romance faz com que ele ganhe novas perspectivas de vida. Seu novo objetivo é cuidar da amada, numa espécie de intercâmbio entre o velho e o novo: no pensamento, nos ideais, na linguagem, no jeito de amar.

Os limites espaciais do eu-lírico são restritos, ao passo que amada, representante das gerações atuais, ultrapassa fronteiras: "Vou até a esquina, ela quer ir para a Flórida".

A incompatibilidade entre os contextos, evidenciada no início de cada estrofe, gera uma aparente barreira para a continuidade do relacionamento entre o par amoroso: "Temo que não dure muito a nossa novela". No entanto, os versos finais da primeira, segunda e última estrofes, reforçados pela marca de oposição "mas", quebram a barreira ao revelar o realidade íntima do eu lírico: "Temo que não dure muito a nossa novela, mas / Eu sou tão feliz com ela / [...] / Acho que nem sei direito o que é que ela fala, mas/ Não canso de contemplá-la / [...] / Sinto que ainda vou penar com essa pequena, mas/ O blues já valeu a pena". Na totalidade da letra, vai se consolidando um campo semântico onde a conjunção "mas" também alude à ideia de aceitação. A aceitação no poema é, dessa maneira, condição para a realização amorosa.

De certo modo, o tema dessa letra poética abre espaço para uma discussão, acerca dos novos modelos de relacionamentos da contemporaneidade, cheia de sinais confusos, capaz de mudar rapidamente e de maneira imprevisível, analisados por Bauman (2004). Nos dias de hoje, a atenção acaba por se concentrar nas expectativas satisfatórias que se deseja obter por meio das relações amorosas. Por outro lado, tais esperanças se transformam em frustrações diante dos sentimentos facilmente descartáveis e da implacável individualização que alcança os relacionamentos. No entanto, seguindo a tendência nostálgica presente nas letras poéticas do álbum "Chico", o eu-lírico não demonstra nenhuma preocupação com o futuro do relacionamento e uma possível decepção: ele tem pouco tempo e deseja aproveitar tudo o que esse amor com uma jovem pode oferecer.

O Blues também é simbólico na letra da canção enquanto forma musical que sempre exerceu grande influência na música popular ocidental. Observa-se mais uma vez o "re-entry" através da mistura entre o velho e o novo, o passado e o presente. Ainda que eu-lírico vá "penar com essa pequena", ou que "não dure muito essa novela", valeu a pena viver essa mistura traduzida num blues. 
O ideal amoroso disseminado por meio do simbólico na canção buarqueana mostra que somente o sentimento amoroso é capaz de superar a vida socialmente pautada no consumo, nas aparências e na fluidez, e as marcas que ela deixa no indivíduo. Desse modo, o amor presente em "Essa pequena" aproxima-se do sentido expresso por Lázaro (1996, p. 222) onde amar "é libertar-se das amarras que fazem de um indivíduo um ser socialmente inscrito e, portanto, limitado".

O inusitado encontro amoroso é uma oportunidade de redescobrir o mundo, da qual fazem parte as variações entre encantamento e desencantamento, novidade e mesmice, finitude e eternidade. Ao reconhecer as condições para a consumação da relação, o eu-lírico aposta na possibilidade de ser feliz vivendo o momento, sem se ater a expectativas da eterna felicidade.

Outra canção que fala das angústias e alegrias trazidas pelo amor é "Tipo um baião". Percebe-se toda confusão afetiva do eu-lírico revelada por meio de um intrincado jogo de metáforas sobrepostas. O sentimento de entrega ao envolvimento amoroso é manifestado pelo ato de dar o coração e tê-lo transformado em fole de sanfona ("Meu coração/ Que você sem pensar/ Ora brinca de inflar/ Ora esmaga"), simbolizando a ambiguidade de sua entrega: ora feliz, ora angustiada. Essa canção também é marcada por estabelecer um rico diálogo com a obra de Luiz Gonzaga. Os versos de "Olha pro Céu” (Luiz Gonzaga e José Fernandes, 1951), “e no terreiro / o teu olhar / que incendiou meu coração", também revelam um coração que sofre consequências físicas como metáfora da sua condição passional.

Não sei para que

Outra história de amor a essa hora

Porém você

Diz que está tipo a fim

De se jogar de cara num romance assim

Tipo para a vida inteira

E agora, eu

Não sei agora

Por quê, não sei

Por que somente você

Não sei por que

Somente agora você vem

Você vem para enfeitar minha vida

Diz que será

Tipo festa sem fim

É São João

Vejo tremeluzir

Seu vestido através

Da fogueira 


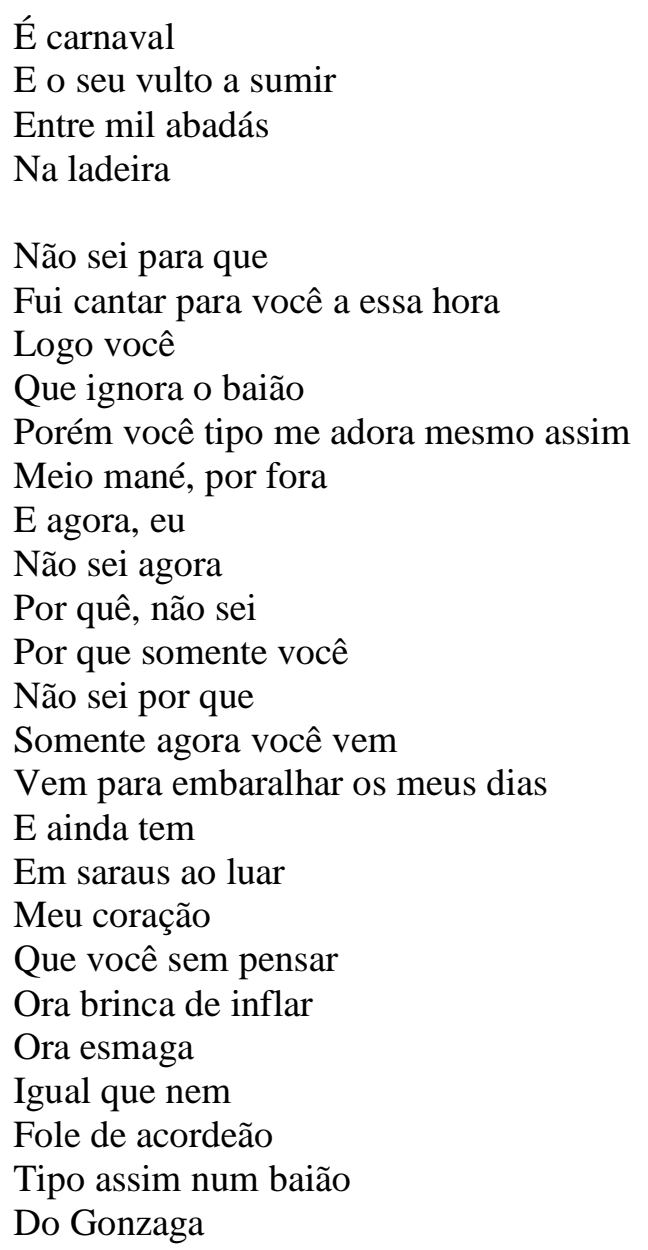

Dividida em duas estrofes, a primeira parte da canção tem um andamento lento que reforça uma atmosfera ligada ao recitar, onde o eu-lírico narra livremente sua confusão diante do inesperado e inconveniente encontro amoroso ("Não sei pra que/ Outra história de amor a essa hora"). Insegurança essa reforçada pelas marcas textuais na repetição dos termos "Não sei"/ "E agora"/ "Por quê" e, sobretudo, muito ligada aos tempos hipermodernos onde cada sujeito, imerso em sua própria liberdade, é exposto a domínios paradoxais que opõem e dividem a sociedade entre uma cultura do excesso e o elogio da moderação.

Por outro lado, sua interlocutora parece segura diante dessa "história de amor", não encontrando impedimentos para "se jogar de cara num romance assim tipo pra vida inteira".

Seguindo a tendência de "Essa pequena", a letra revela ao mesmo tempo um descompasso e uma busca por harmonizar esse desequilíbrio entre o par amoroso.

Entre as diversas marcas de dúvidas do eu-lírico, o trecho "somente agora você vem..." demonstra que o grande impedimento para a concretização deste romance se 
deve ao tempo em que ele demorou a chegar. A partir daí o eu-lírico recupera o controle dos seus sentimentos e começa a refletir sobre o lado bom dessa "nova história de amor".

\author{
Não sei agora \\ Por quê, não sei \\ Por que somente você \\ Não sei por que \\ Somente agora você vem \\ Você vem para enfeitar minha vida
}

O conflito entre o desejo e o medo de se entregar ao inusitado relacionamento amoroso pode ser observado em toda a canção:
Vejo tremeluzir
Seu vestido através
Da fogueira
É carnaval
E o seu vulto a sumir
Entre mil abadás
Na ladeira

Aqui nota-se o encantamento pela luz que o fogo projeta sobre o tecido colorido e, ao mesmo tempo, a sutileza do desamparo de quem fica inerte assistindo o objeto de contemplação partir. Esses versos também carregam a ideia da distância física entre o par. Para o eu-lírico viver esse romance é conviver com a angústia da constante ameaça do afastamento.

No entanto, o "Carnaval" e o "São João" são as "festas sem fim”, onde o eulírico pode viver uma atmosfera de sonho e fantasia, rompendo com a narrativa linear mantida até então.

Os versos "Vejo tremeluzir/ Seu vestido através/ Da fogueira" são um bom exemplo do talento de Chico Buarque para tratar do universo simbólico por meio da palavra, provocando a associação entre os sons presentes nos versos e o que está sendo descrito por meio deles. Nesse trecho, podemos ouvir os estalos produzidos pela fogueira, sugeridos pela associação onomatopaica com os /tr/, e imaginar tanto a imagem da luz gerada pelo fogo, através da associação com as sibilações do /s/ e do /z/, quanto a fluidez do movimento da saia rodando no ar que vaza dos dois /v/.

Se na primeira estrofe o eu-lírico narrou as tensões que envolvem o relacionamento amoroso, no segundo bloco ele desenvolve este conflito de acordo com uma nova perspectiva. Os versos "Não sei pra que / fui cantar pra você a essa hora / logo você / que ignora o baião" reforçam que o par amoroso ignora as referências 
usadas pelo eu-lírico para compor seu momento de fantasia. Portanto, a angústia vivida pelo eu-lírico por não ter seus dramas e aflições compreendidos pelo Outro.

No entanto, o eu-lírico começa a tirar conclusões sobre essa história de amor inesperada, como se a euforia, a ansiedade e o devaneio presentes na primeira estrofe da canção servissem como uma terapia que o leva à reflexão e tomada de consciência sobre seus sentimentos amorosos. De fato, ele passa a "entregar seu coração" à amada por meio de imagens que revelam o maior romantismo como os "saraus ao luar". Um eulírico ainda inconsciente dos seus sentimentos no primeiro bloco, agora é consciente dos seus afetos, buscando revelá-los por meio do simbólico e do imagético.

Os versos finais da canção trazem a referência explícita à obra do compositor pernambucano Luiz Gonzaga. O baião dos versos de "Olha pro céu" (1951), "havia balões no ar / xote e baião no salão", ecoam na letra de Chico:

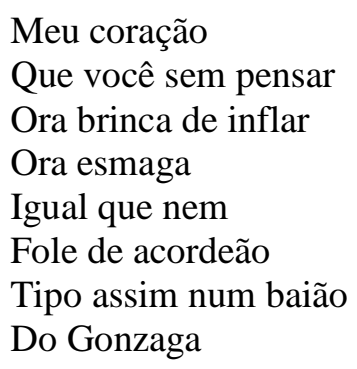

Outra canção de Chico Buarque que faz referência ao baião de Luiz Gonzaga é "Baioque" (1972). Nela podemos observar a voz moderna denominada por Corrêa (2009, p.18) - cuja dissertação de mestrado "Modernidade e pós-modernidade na canção popular brasileira urbana: a voz ativa de Chico Buarque de Hollanda" merece destaque por sua contribuição no desenvolvimento do tema da pós-modernidade em Chico Buarque - como "exclusivista": "Quando eu canto/ que se cuide/ quem não for meu irmão". Já no início da letra o termo "irmão" carrega a ideia de relações restritas entre indivíduos que, de algum modo, compartilham dos mesmos ideais.

Quando eu canto

Que se cuide

Quem não for meu irmão

O meu canto

Punhalada

Não conhece o perdão

Quando eu rio

Quando eu rio

Rio seco

Como é seco o sertão

Meu sorriso 
É uma fenda

Escavada no chão

Quando eu choro

Quando choro

É uma enchente

Surpreendendo o verão

É o inverno

De repente

Inundando o sertão

Quando eu amo

Quando amo

Eu devoro

Todo o meu coração

Eu odeio

Eu adoro

Numa mesma oração

Quando eu canto

Mamie, não quero seguir

Definhando sol a sol

Me leva daqui

Eu quero partir

Requebrando um rock and roll

Nem quero saber

Como se dança o baião

$\mathrm{Eu}$ quero ligar

Eu quero um lugar

Ao som de Ipanema, cinema e televisão

O uso da primeira pessoa é recorrente em "Baioque", "Eu canto/ [...] eu choro/ [...] eu amo/ [...] eu devoro/ [...] eu quero", impondo condições para que o outro se integre a ele. $\mathrm{O}$ emprego do pronome possessivo "meu", "O meu canto/ $[\ldots]$ o meu sorriso", também revela a dificuldade de incorporação do coletivo.

Entre o sertão e o espaço urbano, o eu-lírico acaba por renegar o modelo cultural da tradição representado na letra pelo baião: "Não quero saber/ como se dança o baião". Tradição essa que é marca dos conhecidos versos de Gonzaga em "Baião" (1949): "Eu vou mostrar pra vocês/ Como se dança o baião [...]". Segundo Cyntrão (2004, p. 112113), esses versos emblemáticos de "Baioque" possuem importância para toda obra do artista enquanto "ruptura necessária com o conhecimento aceito, para que novos caminhos se abram descontaminados do passado e de toda sua carga negativa de acomodação ao que é de forma fácil, socialmente aceito". Nesse sentido, as letras poéticas de Chico Buarque tornam-se referência da nação por meio das histórias narradas, "criando o espaço mítico de identidade cultural brasileira". 
Enquanto que o eu-lírico da canção de 1972 renega o espaço das tradições, estabelecendo um espaço de exclusão, em "Tipo um baião" o movimento é contrário: de retomada da tradição por meio dos anseios amorosos compartilhados pelo eu-lírico que se apresenta um tanto deslocado do seu tempo. Sendo assim, o eu-lírico é representativo de um período de valorização da tradição, ao passo que o par amoroso representa o descompasso entre dois tempos e a barreira frente aos modelos do passado. $\mathrm{O}$ encontro amoroso possibilita o retorno à tradição em tempos hiper, o movimento de inclusão, de incorporação e de valorização dos variados modelos culturais, sejam populares, de elite, regionais ou urbanos, típicos da hipermodernidade.

Uma das marcas da canção é o uso das expressões coloquiais. "Tipo" é um termo contemporâneo que expressa como uma coisa se parece. Ele é mencionado cinco vezes na letra, sendo que em quadro delas, a expressão pertence ao discurso da voz feminina. Por outro lado, na única vez que o eu-lírico usa a expressão "tipo assim", sem ser um recorte da voz feminina, é ao traduzir sua própria expressão "igual que nem" para o vocabulário da amada. $\mathrm{O}$ eu-lírico percebe que a arcaica expressão coloquial "igual que nem" utilizada por ele, o distancia, inclusive linguisticamente, ainda mais da amada, possivelmente uma jovem atualizada com as gírias e expressões correntes, ao modo de "tipo assim".

Sobre o papel da paixão para sua criação musical, Chico Buarque (2010) revelou: "Quando a gente começa - isso é um caso pessoal, não dá pra generalizar - faz música um pouco para arranjar mulher. E hoje em dia você inventa amor para fazer música. Se não tiver uma paixão, você inventa uma, para a partir daí ficar eufórico, ou sofrer". "Sem você 2" é uma dessas narrativas de um rompimento amoroso que atualiza os sentimentos do sujeito hipermoderno frente à descontinuidade.

\author{
Sem você \\ É o fim do show \\ Tudo está claro, é tudo tão real \\ As suas músicas você levou \\ Mas não faz mal \\ Sem você \\ Dei para falar a sós \\ Se me pergunto onde ela está, com quem \\ Respondo trêmulo, levanto a voz \\ Mas tudo bem \\ Pois sem você \\ O tempo é todo meu
}


Posso até ver o futebol

Ir ao museu, ou não

Passo o domingo olhando o mar

Ondas que vêm

Ondas que vão

Sem você

É um silêncio tal

Que ouço uma nuvem

A vagar no céu

Ou uma lágrima cair no chão

Mas não tem nada, não

Apresenta-se uma canção contemporânea que segue a tendência do hibridismo por meio do diálogo interiorizado com "Sem você" (1959) de Tom Jobim e Vinicius de Moraes.

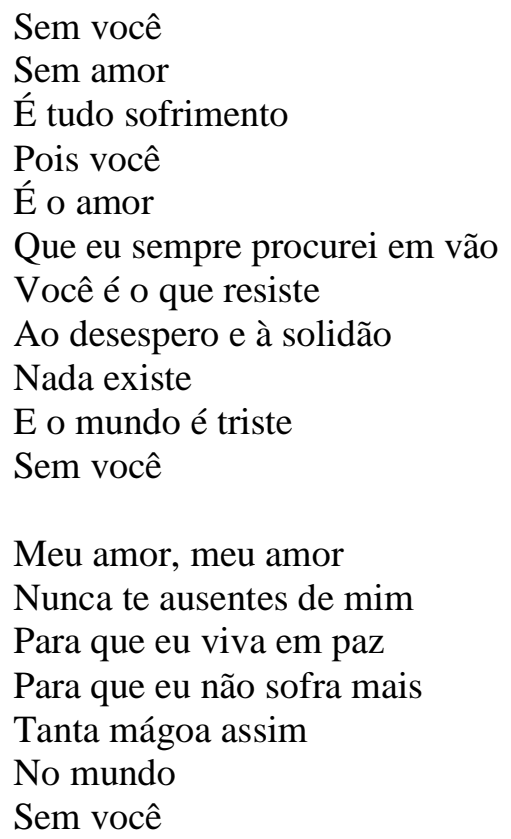

O conceito de transcendência também se faz presente estando associada à concepção de que a ação do tempo remodelou não somente a obra, que ganha a versão atualizada "Sem você 2", mas o próprio artista responsável pela mudança.

No universo da pressa, o vínculo humano é trocado pela rapidez; a qualidade de vida, pela eficiência; a fruição isenta de normas e de cobranças, pelo frenesi. Foram-se a ociosidade, a contemplação, o relaxamento voluptuoso: o que importa é a autosuperação, a vida em fluxo nervoso, os prazeres abstratos da onipotência proporcionados pelas intensidades aceleradas. Na medida em que as relações reais de proximidade dão lugar aos intercâmbios virtuais, se estabelece uma cultura de hiperatividade que valoriza o desempenho, minando o ideal hedonista, a abertura para 
contemplação e o ócio. As experiências vividas pelo sujeito Chico Buarque em meio a esse novo contexto de "cultura da imediatez" o levam a atualizar a canção original.

A constante ameaça do descontínuo e o medo da separação revelam as principais questões do sujeito presente na letra de 1959. O sentimento de perda amorosa é marcado por uma profunda dor, evidenciando a dependência do ser amado e o desejo de abreviar todo sofrimento. As súplicas desvendam a angústia do sujeito na busca da continuidade e o sofrimento causado pela possibilidade de ruptura amorosa, o que resulta no "estado de individualidade descontínua" (FONTES, 1999, p. 37).

Aqui o aspecto espiritual também é levado em conta diante da separação amorosa ("Nunca te ausentes de mim / Para que eu viva em paz"). O amor, desse modo, é tomado como um processo de continuidade do sujeito, no entanto, o fim do sentimento amoroso deixa o indivíduo totalmente perdido diante de uma nova realidade de incompletude: "Sem você / [...] / Nada existe / E o mundo é triste".

Bauman (2011, p. 17) revela outro aspecto ligado ao medo da solidão:

Fugindo da solidão, você deixa escapar a chance da solitude: dessa sublime condição na qual a pessoa pode "juntar pensamentos", ponderar, refletir sobre eles, criar - e, assim, dar sentido e substância à comunicação. Mas quem nunca saboreou o gosto da solitude talvez nunca venha a saber o que deixou escapar, jogou fora e perdeu.

A versão de Chico Buarque, composta em 2011, apresenta uma outra perspectiva do rompimento amoroso. A dor e o sofrimento dão lugar à aceitação, ao conformismo ("Mas não faz mal / [...] / Mas tudo bem / [...] / Mas não tem nada, não"), pois a situação agora é irremediável ("Sem você / É o fim do show / Tudo está claro, é tudo tão real"). Não existe mais o enfrentamento da separação, a súplica e a angústia frente à "descontinuidade" do sujeito. No poema, a realidade da ausência se impõe, seja por meio da fala do eu-lírico diante do vazio interior ("Dei pra falar a sós / Se me pergunto onde ela está, com quem / Respondo trêmulo, levanto a voz"), seja pelo relato exteriorizado da ausência frente às novas possibilidades, num rompimento com o aspecto espiritual presente na obra de Tom e Vinicius ("O tempo é todo meu / Posso até ver o futebol / Ir ao museu, ou não").

O sentido da transcendência acontece por meio dessa conscientização e aceitação da ausência e pode ser evidenciado na última estrofe onde, o eu-lírico

[...] deslocando a instância enunciativa do contexto da ausência da musa para o contexto do silêncio da ausência ("Sem você / É um silêncio tal / Que [...]"), insere no contexto mediato da transcendência 
("[...] ouço uma nuvem / A vagar no céu") o contexto imediato da experiência subjetiva ("Ou uma lágrima cair no chão"), que, contrapostos no efeito sinestésico de audição da imagem e da alternativa conjuntiva ("[...] ouço uma nuvem / [...] / Ou uma lágrima [...]"), polarizam o eixo transcendental ("[...] no céu" / "[...] no chão"). (SILVA, 2013, p. 84-85)

Esse panorama leva a refletir que a aceitação diante do definitivo rompimento amoroso, não traz consigo o conforto, mas a melancolia de um sujeito amoroso conformado. A melancolia aqui é representativa do sentimento de nostalgia presente nas canções do álbum Chico, reforçado, inclusive, pela estrutura melódica e outros recursos musicais de mistura de gêneros e ritmos, ali presentes.

Mesmo com o passar dos séculos, a mudança dos cenários e contextos, as consequências do amor não se alteram. Aqui, em contraste com os modelos consolidados, percebe-se a transgressão da concepção neoplatônica do amor que concebe a mulher como origem de sublimação e ascese.

Tratando de algumas das características da separação, Giddens (1993, p. 116117) escreve:

Quando um relacionamento termina, uma imagem do outro, hábitos associados ao outro e a expectativa de que possa ocorrer uma reconciliação persistem posteriormente por muitos anos, não apenas para a pessoa abandonada, mas até mesmo para quem toma a iniciativa da separação. O luto é a condição do desprendimento de hábitos que do contrário transformam-se em traços viciados no presente. [...] Em cada caso há um rompimento cognitivo e emocional com o passado psicológico, assim como uma reescrita da narrativa do eu.

Num mundo de velocidade e aceleração, o comportamento torna-se orientado pelo impulso, pela influência do poder do mercado de consumo, inclusive nos relacionamentos. Como em qualquer investimento que envolve tempo, dinheiro e esforços que poderiam estar sendo aplicados para outros fins, em um relacionamento também se espera gozar do lucro, nesse caso, denominado "segurança": a companhia fiel que lhe serve de consolo e apoio em qualquer momento da vida. Entretanto, é preciso ficar atento, pois "estar num relacionamento" significa, principalmente, uma incerteza constante. De outra forma, diante da instantaneidade e da disponibilidade atuais, quanto menos se investe numa relação, menos inseguro o sujeito vai se sentir diante da instabilidade de suas emoções futuras. 
De acordo com Silva (2013, p. 84), a tematização da transcendência está "no deslocamento evasivo para a realidade ficcional, em busca da musa romanesca". "Nina" é essa inspiração romanesca do mundo da ficção.

Nina diz que tem a pele cor de neve

E dois olhos negros como o breu

Nina diz que, embora nova

Por amores já chorou

Que nem viúva

Mas acabou, esqueceu

Nina adora viajar, mas não se atreve

Num país distante como o meu

Nina diz que fez meu mapa

E no céu o meu destino rapta

$\mathrm{O}$ seu

Nina diz que se quiser eu posso ver na tela

A cidade, o bairro, a chaminé da casa dela

Posso imaginar por dentro a casa

A roupa que ela usa, as mechas, a tiara

Posso até adivinhar a cara que ela faz

Quando me escreve

Nina anseia por me conhecer em breve

Me levar para a noite de Moscou

Sempre que esta valsa toca

Fecho os olhos, bebo alguma vodca

E vou

A canção apresenta duas dimensões significantes, a real e a ficcional. A dimensão real é elaborada por meio das referências do mundo real, a dimensão ficcional se fixa à real por meio de situações existenciais imaginárias, dando origem à proposição de realidade ficcional do romance.

Nina é uma musa romanesca, que vive uma situação de realidade imaginária no mundo da ficção, que é outro mundo, apartado do mundo da experiência histórica do poeta, pelo qual transitam as musas inspiradoras da lírica. A moldura de realidade do seu mundo pode ser vista na "tela" com riqueza de detalhes, o país, a cidade e até mesmo a casa onde mora, mas não ela mesma, uma criatura ficcional concebida na imaginação do autor. Nina escreve cartas e, embora a barreira intransponível que separa os dois mundos, o real e o ficcional, espera conhecer o poeta em breve, desejo esse, em princípio, impossível de realizar-se. (SILVA, 2013, p. 86)

No entanto, as barreiras do tempo e do espaço não existem para o eu lírico que "referenciando a proposição de realidade ficcional da personagem, rapta a musa romanesca numa valsa russa e a exibe na janela lírica das musas poéticas da MPB, para 
dialogar com o poeta. E toda vez que a valsa toca, ela interrompe alguma carta e vem" (SILVA, 2013, p. 86).

A “tela” em Nina é de fato uma janela que, conforme explicou Nelson Rodrigues (1993, p. 72), “nos põe em relação direta, fulminante, com o infinito". É por meio da janela que acessamos o mundo, e hoje, graças às fortes mudanças sofridas em nossa sociedade, as telas da televisão e do computador converteram-se em janelas contemporâneas que acessamos de dentro de casa.

Há na letra um sentido de "coisa perdida", uma sensação de nostalgia frente à distância, à impossibilidade do encontro "de corpo presente" que precisa ser amenizada por meio do sonho, da imaginação do poeta: "Fecho os olhos, bebo alguma vodca / E vou".

O paradoxo da composição é que apesar das marcas que permitem contextualizar a canção dentre do mundo hipermoderno, o comportamento das personagens vai de encontro à agitação, frieza e descartabilidade contemporâneos, como visto em "Querido Diário", por exemplo. Pelo contrário, a relação à distância é leve e sutil, aos moldes dos "amores impossíveis" românticos. O amor sublime também poderia ser citado aqui visto que as barreiras espaciais que dificultam a paixão são convertidas em troca simbólica.

Essa relação entre o tempo acelerado, das mídias sociais, e o tempo redescoberto, que recicla o ideal romântico em plena hipermodernidade com um toque de nostalgia, é assim explicado por Silva (2010, p. 32):

\begin{abstract}
A proposição de realidade pressuposta é sempre um recorte da imagem de mundo imediata do eu-lírico e se confunde também, constantemente, com o segmento espaçotemporal do eu histórico da experiência lírica, o poeta. Embora a proposição de realidade pressuposta tenha que ser, obrigatoriamente, o segmento histórico imediato da experiência do eu-lírico, nada obriga, todavia, que ele coincida sempre com o segmento histórico imediato da experiência do poeta, ou seja, a experiência lírica muitas vezes se dá num segmento espaçotemporal diverso do da experiência histórico-pessoal do poeta. (SILVA, 2010, p. 32)
\end{abstract}

De acordo com Pedro Lyra (2013, p. 274), esteticamente, nas letras das canções populares, "explora-se bem mais a esperança do amor faltante ou a lembrança do amor malogrado do que a vivência do amor feliz". Isso se deve ao fato de que num estado feliz o impulso do sujeito se volta para o desfrute imediato, já que esse momento é breve. Já num estado de carência (desejo, falta ou perda), o impulso se dirige ao desejo 
de superação o mais imediatamente possível, visto que quanto mais prolongado mais insuportável é a angústia. Nesse último caso, o sujeito precisa preencher seu vazio existencial, do contrário ele sucumbe. Quando esse sujeito é um artista ele ocupa o vazio por meio da sua obra concretizando no plano do imaginário o que não conseguiu realizar no plano da realidade. A fala de Chico reforça essa tendência "[...] hoje em dia você inventa amor para fazer música", todavia na letra de "Sem você 2", que trata de rompimento amoroso, não há a angústia representativa da descontinuidade.

A canção remete ao poema "Cantiga para não morrer"10, de Ferreira Gullar: "Quando você for se embora/ moça branca como a neve/ me leve...". Mas a Nina da "pele cor de neve" da letra de Chico Buarque só existe na imaginação do eu-lírico. Embalada por acordeão e vodca, a canção fala de devaneios, amores por correspondência, amores virtuais e do sonho.

Sobre os relacionamentos virtuais, segundo Lázaro (1996, p. 215), “a ampliação quantitativa dos meios de comunicação envolve não só um maior número de indivíduos mediatizados por esses processos na construção social da subjetividade, como também se altera a qualidade desse envolvimento". Bauman (2004, p. 12-13) apresenta um interessante exemplo dessa problemática ao caracterizar os atuais "relacionamentos virtuais" que, ao contrário dos "reais", não preveem o comprometimento e a dedicação que podem se converter em frustrações diante de um possível rompimento: “Diferentemente dos 'relacionamentos reais', é fácil entrar e sair dos 'relacionamentos virtuais'. Em comparação com a 'coisa autêntica', pesada, lenta e confusa, eles parecem inteligentes e limpos, fáceis de usar, compreender e manusear".

Em "Nina" a opção é pela vivência do amor feliz. Assim como em "Essa pequena”, onde o eu-lírico declara conhecer a brevidade da relação, mas aceita tal condição para ser feliz enquanto ela durar ("Temo que não dure muito a nossa novela, mas/ Eu sou tão feliz com ela"). Essas duas canções são representativas da ideia contemporânea de amor romântico, devidamente reciclada dentro da lógica hipermoderna.

\footnotetext{
${ }^{10}$ Quando você for se embora,/ moça branca como a neve,/ me leve./ Se acaso você não possa/ me carregar pela mão,/ menina branca de neve,/ me leve no coração./ Se no coração não possa/ por acaso me levar,/ moça de sonho e de neve,/ me leve no seu lembrar./ E se aí também não possa/ por tanta coisa que leve/ já viva em seu pensamento,/ menina branca de neve,/ me leve no esquecimento.
} 
As imagens oníricas em "Nina" ganham vida, não devido ao relato comum a qualquer sonho, mas graças ao arranjo de letra e música onde imaginário e simbólico se entrelaçam. Também pode-se notar a contaminação entre sonho e realidade, onde realidade e ficção se tornam indiscerníveis. Para sobreviver compomos e moldamos uma realidade de acordo com a necessidade.

Enquanto corporificação da musa romanesca, Nina é uma das personagens femininas mais representativas no álbum. A trajetória lírica da mulher no curso da obra de Chico Buarque está relacionada à própria trajetória histórica da mulher. Contudo esse percurso não está contido na problemática do conflito particular feminino, mas "projetada na problemática existencial dos seres humanos, participando do coro lírico juntamente com as outras vozes e constituindo, como essas, uma subjetividade social com ponto de vista próprio acerca de sua participação na sociedade" (SILVA, 2010, p. 132).

\begin{abstract}
A mulher entra na poesia de Chico Buarque da mesma maneira que entra em toda obra lírica, como musa inspiradora colhida no fluxo da motivação poética. Nada diferente ainda, no fato de ser, de início, a musa sublimada, ou seja, um ser etéreo moldado na imaterialidade da fantasia e do sonho que logo depois se converte na musa transgressora, isto é, no ser corporificado na materialidade social da realidade. Não surpreende que o espaço social da musa sublimada seja a casa e o espaço social da musa transgressora seja a rua, e que estes dois espaços estejam delimitados pela janela. Na tradição lírica, pelo menos até o romantismo, a casa da musa sublimada abria-se para os jardins floridos e os bosques idílicos, com fontes murmurantes, mas esses anteparos desaparecem com a evolução urbana, trazendo a rua para debaixo da janela da musa. (SILVA, 2010, p. 133)
\end{abstract}

Seguindo o conceito da canção popular brasileira como produto cultural transfigurador do real que atua na manipulação de um patrimônio simbólico coletivo e reconhece seu criador como sujeito capaz de ressignificar esteticamente as tradições culturais, observa-se a entrevista de Chico Buarque à "Revista Gol", transcrita no livro de Zappa (2011, p. 420), onde o artista fala sobre a velhice e a morte:

Gosto muito da vida, não quero morrer, não. Quero viver, viver bastante. E viver bem. Acho que com saúde, fazendo as coisas direito, dá pra viver um bocado mais. Gostaria de viver com saúde e com imaginação, com vontade de criar coisas. Aos noventa e tantos anos e virando a noite por causa de uma música, por causa de um livro. Formidável.

Vê-se mais um exemplo de como a "persona", formada pela experiência pessoal, aparece como voz discursiva na obra: essa é justamente a temática do samba 
"Barafunda" em homenagem à própria velhice que vai chegando. A canção tem a memória como objeto. Nela o eu-lírico quer apontar para o esquecimento, para a confusão mental - esquecer, misturar tudo na memória como ocorre com o avançar da idade - por isso o título "Barafunda": ligeira confusão mental que se estabelece com a passagem dos anos.

O samba possui uma história ligada à cultura popular. Durante longo tempo, foi posto à margem da cultura oficial e sofreu privações pelo seu apelo sensual e sua ligação com a cultura afro-brasileira. O carnaval também pode ser mencionado aqui enquanto espaço de vinculação do samba e é citado por Affonso Romano de Sant'Anna como uma metáfora na obra de Chico Buarque, sobretudo como um apelo à liberdade em canções mais engajadas. De acordo com o estudioso: "O carnaval é como a passagem da banda. Vive-se aí o instante de utopia. Cria-se o estado de exceção” (1978, p. 170).

A memória em "Barafunda" não está apenas em momentos marcantes da nossa história presentes na letra, mas no seu arranjo, na gravação dos instrumentos, no coro, na performance. Vemos um sujeito que já não consegue colocar os fatos em ordem, misturando em uma série de recordações fatos ligados ao futebol, às mulheres, à história, ao carnaval e ao amor: "Misturam-se os fatos, as fotos são velhas".

Era Aurora, não, era Aurélia

Ou era Ariela, não me lembro agora

É saia amarela daquele verão

Que rola até hoje na recordação

Foi na Penha, não, foi na Glória

Gravei na memória, mas perdi a senha

Misturam-se os fatos, as fotos são velhas

Cabelos pretos, bandeiras vermelhas

Foi Garrincha, não, foi de bicicleta

Juro que vi aquela bola entrar na gaveta

Tiro de meta

Foi na guerra, é noite alta

Gritou o astronauta que era azul a terra

Quando a Verde e Rosa saiu campeã

Cantando Cartola ao romper da manhã

Salve o dia azul, salve a festa

E salve a floresta, salve a poesia

E salve este samba

Antes que o esquecimento

Baixe seu manto, seu manto cinzento 
Foi Glorinha, não, era Maristela

Juro que eu ia até casar na Penha com ela

A vida é bela é...

Não é, era Zizinho, era Pelé

Era Soraya, era Anabela, era amarela a saia

Foi quando a Verde e Rosa saiu campeã

Cantando Cartola ao romper da manhã

Salve o dia azul, salve a festa

E salve a floresta, salve a poesia

E salve este samba

Antes que o esquecimento

Baixe seu manto, seu manto cinzento

Era Aurora, não, era Barbarela

Juro que eu ia até o Cazaquistão atrás dela

A vida é bela

É Garrincha, é Cartola e é Mandela

Observa-se que muitas palavras remetem ao universo da velhice, da perda de memória: "não me lembro", "recordação", "memória", "perdi a senha”, "misturam-se os fatos", "as fotos velhas". As mulheres, assim como os fatos históricos e futebolísticos, também aparecem embaralhadas na sua vida. Começa com "Aurora" propositalmente: o início da manhã, o início do texto, da vida e seguindo numa busca eterna por essa memória: "Era Aurora/ Não, era Barbarela/ Juro que eu ia até o Cazaquistão atrás dela".

Esse exercício de acessar os fatos memoráveis converte-se numa exaltação aos feitos representativos de uma vida: seus líderes e referências no futebol ("Zizinho", "Pelé", "Garrincha"), na música (o ícone Cartola e os sambas da "Verde e Rosa", a Mangueira) e na política ("Mandela"). Assim como a alusão à fatos históricos ("Foi na guerra [...]/ Gritou o astronauta que era azul a terra") e à cidade do Rio de Janeiro ("Penha", "Glória"), um espaço que remete ao título dessa pesquisa e à canção "Querido diário": uma cidade "toda em contramão" em meio à mistura e à desordem de "[...] buzinas, sirenes, estardalhaço", seguindo a tendência da confusão mental do eu-lírico.

De algum modo, a própria obra sofre um processo de reciclagem marcado pelo fluxo constante de transformações pelo qual as coisas se fazem e se convertem noutras. A memória e a intenção do poema refazem-se incessantemente. $\mathrm{O}$ eu-lírico testa sua memória e, ao mesmo tempo, avalia sua experiência de vida, num processo que esgota, inclusive, a experiência lírica de criação da obra ao notarmos que as mesmas lembranças vão e vêm no fluxo da memória. A perda de consciência do eu-lírico reflete- 
se na conscientização do próprio fazer poético e de entendimento da própria obra, mas "a vida é bela": a mensagem é positiva, reforçada pelo ritmo do samba que adiciona e reitera ao sentido a dimensão musical com conotações alegres e positivas da afirmação.

De acordo com Silva (2013), a composição é, ao mesmo tempo, uma celebração, um ritual de passagem e uma festa de começo do novo tempo que se proclama.

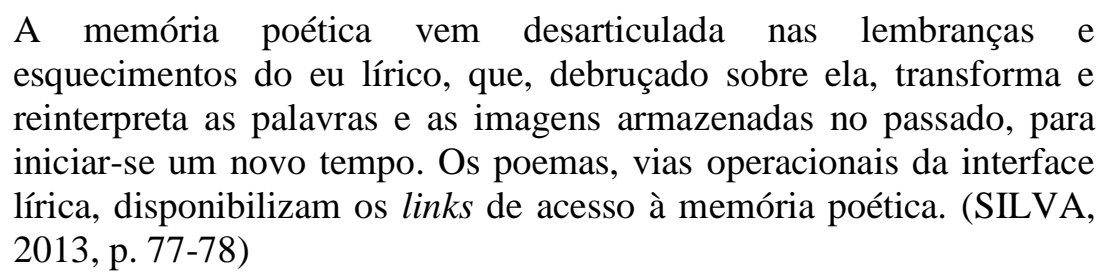

A memória que reconstrói o passado no tempo presente, eliminado, reinterpretando, reciclando os dados depositados, para, ao final do processo, declarar um novo tempo. No poema, o eu-lírico está passando por esse processo: juntando o emaranhado de lembranças desordenadas e esquecimentos. No entanto, só as lembranças memoráveis são resgatadas para compor o poema do presente, "Barafunda", ("Salve o dia azul / Salve a festa / E salve a floresta, salve a poesia / E salve este samba [...] / [...] / A vida é bela"), somente as lembranças do passado, capazes de idealizar o novo tempo, serão cantadas no poema, o resto ficará no esquecimento (“[...] antes que o esquecimento / Baixe seu manto / Seu manto cinzento").

Assim como Chico exaltou a vida na entrevista citada ao dizer "Gosto muito da vida", o eu-lírico da canção repete: “A vida é bela”, porque há lembranças, que apesar de misturadas, merecem ser cultuadas e dão sentido à vida. O sujeito poético, assim como o sujeito compositor, encara isso com naturalidade neste samba.

"Sinhá" é a última faixa do álbum e tem a participação do compositor João Bosco. É uma história contada em duas vozes: a da "persona" poética, narrando uma história, e a de um escravo, acusado de ver Sinhá se banhar, que implora para não ser castigado:

\footnotetext{
Se a dona se banhou

Eu não estava lá

Por Deus Nosso Senhor

Eu não olhei Sinhá

Estava lá na roça

Sou de olhar ninguém

Não tenho mais cobiça

Nem enxergo bem

Para que me pôr no tronco

Para que me aleijar
} 
Eu juro a vosmecê

Que nunca vi Sinhá

Por que me faz tão mal

Com olhos tão azuis

Me benzo com o sinal

Da santa cruz

Eu só cheguei no açude

Atrás da sabiá

Olhava o arvoredo

Eu não olhei Sinhá

Se a dona se despiu

Eu já andava além

Estava na moenda

Estava para Xerém

Por que talhar meu corpo

Eu não olhei Sinhá

Para que que vosmincê

Meus olhos vai furar

Eu choro em iorubá

Mas oro por Jesus

Para que que vassuncê

Me tira a luz

E assim vai se encerrar

O conto de um cantor

Com voz do pelourinho

$\mathrm{E}$ ares de senhor

Cantor atormentado

Herdeiro sarará

Do nome e do renome

De um feroz senhor de engenho

E das mandingas de um escravo

Que no engenho enfeitiçou Sinhá

Durante toda a letra o escravo defende sua inocência e tenta sensibilizar o cruel senhor de engenho que, mesmo "como olhos tão azuis", ainda "faz tão mal" ao escravo. Mas na última estrofe os versos são atualizados, ganha voz a "persona" poética. O indivíduo Chico Buarque presente nesse álbum consegue mais uma vez dialogar com o tempo, com a história, com o que ficou e com o que virá. Por trás da voz do escravo que pede clemência ao senhor de engenho, percebe-se a segunda voz, a voz do:

Cantor atormentado

Herdeiro sarará

Do nome e do renome

De um feroz senhor de engenho

E das mandingas de um escravo

Que no engenho enfeitiçou Sinhá 
Essa é a voz que conta as suas origens, é o sujeito histórico falando das relações de escravo e senhor de engenho de onde tantos brasileiros vieram. Síntese da miscigenação, cabe sublinhar que a história da família de Chico Buarque está intimamente ligada a esse momento da história brasileira narrado na canção. De acordo com o livro Buarque - uma família brasileira (2007), a árvore genealógica de Chico Buarque nasce da união de José Ignácio Buarque de Macedo, poderoso senhor de engenho do Nordeste, com a ex-escrava Maria José Lima.

Composta por cinco estrofes, pode-se agrupar as quatro primeiras, todas com oito versos cada, enquanto representantes da voz do escravo que canta a sua história, e a última estrofe, com dez versos, revela o narrador do conto, ou seja, a voz do compositor. Em meio ao som dos instrumentos de percussão e de vários violões, que remetem e formam a corá ${ }^{11}$, a estrofe final também é diferenciada pelo tom maior. Terminada a narrativa, permanece o instrumental, todos os sons juntos compondo a "festa do nosso escravo", conforme explicou Chico Buarque no documentário "Dia Voa" (2011), de Bruno Natal, que acompanhou e divulgou a gravação do disco Chico.

O andamento desacelerado em "Sinhá" faz o ouvinte acompanhar um conto fundamentado com apoio da historiografia, cuja crueldade dos castigos e da dor física são amenizados pelo embalo da canção. Novamente nos deparamos com a importância sígnica dos elementos musicais que somados à letra formam uma densa convergência entre performance e canção, conforme os estudos de Zumthor. De acordo com ele, a performance é parte privilegiada da recepção onde o enunciado é de fato recebido. Assim, todo texto poético é performativo, na medida em que percebemos a sua materialidade, o peso das palavras, sua base acústica e as reações que elas produzem em nossos centros nervosos. É a partir daí que nos apropriamos dele, interpretando-o e reconstruindo-o ao nosso modo (ZUMTHOR, 2007, p. 50-54). Essa característica acompanha todas as canções do álbum Chico onde uma grande orquestra é condensada num pequeno conjunto.

Anteriormente foi visto que o coro lírico é composto pelas vozes, incluindo a do eu-lírico, que representam as várias subjetividades mescladas, mais os diversos

\footnotetext{
${ }^{11}$ Corá é um tradicional instrumento musical utilizado por povos na África Ocidental, uma harpa-alaúde de vinte e uma cordas.
} 
contextos socioculturais de onde emergem essas vozes. É por meio do entrelaçamento de referenciais culturais, históricos e simbólicos inerentes as diferentes vozes enunciativas que observamos em "Sinhá", e nas demais composições de Chico, a representação das mais diversas formas de regionalismo:

\begin{abstract}
Englobando costumes e hábitos, crenças, falares, culinária, festejos, tipos humanos, fauna e flora, geografia econômica e recursos naturais, memória histórica, mitos de fundação, condicionamentos psicológico e cultural, folclore, tradição literária erudita e popular, a variedade dos gêneros musicais, a movimentação das massas nas grandes cidades, as diferentes zonas de alojamento, os bairros, os morros, os subúrbios e toda a diversidade das práticas sociais e comunicativas, constroem eles mesmos, superpostos e inter-relacionados, uma unidade contextual identitária, de onde irrompe a voz nacional. (SILVA, 2010, p. 142)
\end{abstract}

Essa voz enunciativa, inerente à voz poética e incorporada no fluxo lírico da criação, representa os anseios de uma "comunidade humana peculiar", forjada através dos hábitos, costumes, ideais e atitudes próprias das subjetividades sociais (SILVA, 2010, p. 142). A incorporação das representações do social ao coro lírico torna a lírica buarqueana um dos mais pungentes e significativos feitos brasileiros de poesia social. Essa voz nacional acompanha a evolução do projeto poético de Chico e das demais vozes, atualizadas com as transformações dos espaços sociais.

Na canção, o individual dá lugar ao social, a pessoa torna-se personagem, de testemunha de seu momento histórico para obra de arte, ficção. O que vale não é a emoção nem a experiência individual, pois "estas não chegam a ser nunca artísticas, a menos que consigam uma participação no geral por meio, precisamente, da especificação que é o seu estético tomar forma” (ADORNO, 1962, p. 54). Não são os detalhes da história familiar de Chico Buarque que tornam "Sinhá" uma obra de alto nível poético. O conteúdo da canção vai além de um testemunho histórico ou de uma mensagem política, o que faz com que a letra ultrapasse o campo da informação e adentre os domínios da arte é justamente sua competência formal. Passamos do particular ao universal quando a mensagem, fortalecida pelo poder de organização da palavra poética, nos atinge e permanece pela forma, enquanto poesia regida pelo código da arte. Não é mais a experiência do indivíduo, no caso de "Sinhá" a abordagem de uma genealogia familiar específica, que é focada, mas a experiência do ser humano marcada pela origem da diversidade cultural brasileira presente na letra. Ainda citando Adorno: 
"Só entende o que diz o poema aquele que percebe na solidão do mesmo a voz da humanidade" (ADORNO, 1962, p. 54).

Antonio Candido (1995, p. 246) em "O direito à literatura" ao abordar a sistematização da palavra poética por meio da forma, afirma que "A mensagem é inseparável do código, mas o código é a condição que assegura o seu efeito". Esse efeito é garantido nas composições de Chico Buarque pela utilização de variados recursos que provocam o enfeito encantador da palavra, a sonoridade das rimas, os recursos do ritmo e da melodia, a força das imagens contidas em cada figura de linguagem. Nesse caso, a força da palavra poética "permite que os sentimentos passem do estado de mera emoção para o de forma construída, que assegura a generalidade e a permanência". A canção de Chico, como dito, extrapola o individual e atinge o universal, mas fazem parte desse universal os questionamentos de cada ser humano que é afetado em sua memória e sensibilidade por cada verso do artista: "A forma permitiu que o conteúdo ganhasse mais significado, e ambos, juntos, aumentaram a nossa capacidade de ver e de sentir" (CANDIDO, 1995, p. 247-248).

$\mathrm{O}$ conflito religioso, presente na letra por meio de diversas marcas textuais (" $\mathrm{Eu}$ choro em iorubá/ Mas oro por Jesus", "Me benzo com o sinal/ Da santa cruz"), revela a origem da diversidade cultural brasileira que é atualizada no contexto dinâmico e multifacetado da hipermodernidade: "Com a desestruturação dos modelos de classe e a individualização dos modos de ser e de viver, a imprevisibilidade dos comportamentos culturais cresce notavelmente" (LIPOVETSKY, 2007, 28).

Podemos, assim, analisar a originalidade contemporânea. Se nas sociedades tradicionais o modelo cultural era altamente interiorizado, hoje, ao contrário do que parece, existe uma espantosa satisfação de ordem material, ao passo que as decepções de ordem cultural se alastram rapidamente. São justamente essas condições que estabelecem uma individualização extrema das preferências dos sujeitos. O capitalismo hipercomercial por sua vez estabelece uma abundância de oferta, com múltipla variedade de produtos culturais, toda essa inflação das novidades e seu curto tempo de vida útil que causam a sensação de desapontamento na sociedade de consumo, e não a massificação do universo cultural.

No livro de Regina Zappa Para seguir minha jornada (2011, p. 421), encontramos a seguinte afirmação: "José Miguel Wisnik, músico e crítico literário e musical, se referiu a 'Sinhá' como 'uma impressionante formulação da doçura e da 
truculência brasileiras, bebidas na mesma fonte, e um salto poético na elaboração do enigma terrível e fascinante da ambivalência da nossa mestiçagem"”.

Em "Sinhá" o conceito de hibridismo, presente nas letras do álbum Chico enquanto expressão do comportamento hipermoderno, se faz presente por meio das lembranças hereditárias do sujeito poético. Essas experiências conflituosas do passado estão associadas à herança ancestral de origem da identidade cultural do povo brasileiro, quer pela linguagem ("vosmecê / vosmincê/ vassuncê/ Xerém/ pelourinho"), quer pelas personagens e suas características (o senhor de engenho "com olhos tão azuis" e o escravo "sarará").

Silva (2013, p. 87) afirma que o compositor idealiza sua identidade lírica "na contraposição das lembranças originárias”, assumindo, assim, seu legado híbrido. Daí emana o cantor "Com voz de pelourinho / E ares de senhor". Ainda segundo o estudioso: "Para lançar as lembranças atávicas no esquecimento da memória poética, o poeta reinterpreta e transforma o legado ancestral da hibridação cultural originária, para consumar o 'conto' do 'Cantor atormentado"'.

A sociedade hipermoderna, ao minar as esperanças revolucionárias e focar a vida nas felicidades privadas, estimulou, paradoxalmente, uma vontade de reconhecimento da especificidade atribuída pelas raízes coletivas. Daí o retorno prestigioso do passado que extrapola o culto ao retro, às comemorações e ao patrimônio histórico. Com efeito, ele ocorre mais intensamente no despertar das espiritualidades e das novas solicitações identitárias. As sociedades contemporâneas sentem a necessidade de continuidade entre passado e presente, de um fortalecimento de referenciais que remetem às raízes e às memórias religiosas, étnicas, regionais e nacionais.

A canção "Sinhá" finaliza o disco numa atmosfera tão lírica quanto melancólica do legado da escravidão. Os versos "E assim vai se encerrar/ o conto de um cantor/ com voz do pelourinho/ e ares de senhor" encerram o álbum em preto e branco, repetindo os tons da capa.

Pretendendo um maior aprofundamento da investigação acerca do conceito de amor contemporâneo, a partir da análise das canções de Chico Buarque, sugeri na minha dissertação de mestrado, “A tradução da tradição amorosa do par romântico em canções selecionadas de Chico Buarque de Hollanda" (2010), a articulação dos três registros essenciais da realidade humana definidos por Lacan - o Simbólico, o Imaginário e o Real - como operadores de leitura dessas letras poéticas que tratavam de uma das 
maiores preocupações do sujeito contemporâneo: a tensa experiência amorosa na relação com o Outro. Conforme explicou Rossi (2003. p. 14):

Numa sucinta apresentação, o imaginário corresponde ao ego, cujo investimento libidinal Freud chamou de narcisismo; o simbólico diz respeito às instâncias da linguagem, da cultura e do inconsciente estruturado como uma linguagem; o real é aquilo que é impossível de simbolizar. Como um resto, uma sobra que denuncia os limites do simbólico, o real é aquilo que, sem nome e sem forma, insiste, voltando sempre ao mesmo lugar. Enquanto o imaginário revolve-se na busca pela consistência sempre frustrada de um eu que, como uma miragem, continuamente surge para se desfazer nas correntezas do desejo, o real é o resto que o imaginário não pode recobrir e que o simbólico é impotente para capturar.

Após a análise das letras selecionadas pode-se citar novamente o trabalho de Bachelard (1974, p. 344) que estudou a imagem poética em sua origem, por meio de uma fenomenologia da imaginação pura:

A exuberância e a profundidade de um poema são sempre fenômenos da dupla: ressonância-repercussão. Parece que, por sua exuberância, o poema desperta profundezas em nós. Para nos darmos conta da ação psicológica de um poema, teremos pois de seguir duas linhas de análise fenomenológica: uma que leva às exuberâncias do espírito, outra que vai às profundezas da alma.

Conectado à vida urbana contemporânea, formada por uma "íntima interação entre as pressões globalizantes e o modo como as identidades locais são negociadas, construídas e reconstruídas" (BAUMAN, 2004, p. 121), o sujeito somente conseguirá revelar as aflições e expectativas mais íntimas do seu ser, que habitam seu nível do imaginário, através das formas simbólicas.

Parte-se da ideia de que a literatura, enquanto produto do imaginário humano, é representativa dos ideais e questionamentos do sujeito contemporâneo, apontando seus conflitos, suas multiplicidades, sua fragmentação e como idealiza sua identidade a partir da sua visão do Outro.

Representado no nível do simbólico e, consequentemente, na letra da canção, o desejo por liberdade e completude acaba cristalizando-se envolto por uma nuance de nostalgia ligada ao retorno de uma tradição devidamente remodelada dentro do contexto hiper. Dessa forma, o eu-poético torna-se capaz de revelar suas verdadeiras aspirações, muitas delas ocultas ao nível do real. Realidade essa do sujeito Chico Buarque que, apesar de não se dizer nostálgico, parece partilhar desse desejo pela tradução da tradição representado no simbólico de suas letras poéticas: “[...] não penso que éramos mais 
bonitos, mais magros e mais felizes, embora tudo isso seja verdade" (O Estado de São Paulo, 2005). 


\section{CONCLUSÃO}

Os efeitos das revoluções tecnológicas e sociais, como a globalização e os avanços nos meios de comunicação, são experimentados por cada um de nós na medida em que intervêm no nosso dia a dia, nas nossas relações, promovendo sensações contraditórias de aproximação e repulsa, união e isolamento típicas da hipermodernidade. Daí a origem do conflito e da crise de identidade dos sujeitos que vivem numa época marcada por incertezas e instabilidades.

Tão complexo quanto assimilar o período em que vivemos, é explicar a definição de identidade neste momento transitório, de diversidades identitárias. A visão dos sujeitos sobre si mesmos se modifica rapidamente, seguindo a tendência social das identidades cada vez mais elásticas e permeáveis com o objetivo de abranger as múltiplas culturas que compõem o mundo globalizado. Sendo assim, afirma-se que a origem do conceito de identidade está na interação entre o público e o privado e que a alteridade segue sendo marcada pela identidade social hipermoderna: uma sociedade complexa pressupõe sujeitos igualmente complexos. A organização das identidades contemporâneas está baseada nas diferenças, ou seja, na variedade de costumes e ideais que envolvem os sujeitos e os tornam híbridos.

O descentramento do sujeito contemporâneo, por sua vez, possibilitou o reconhecimento da periferia, da cultura das margens, da aproximação entre fronteiras, e de experiências agregadoras e interculturais. Nesse sentido, o fenômeno da hibridação ocorre por processos migratórios, turísticos e tecnológicos, graças à facilidade e rapidez dos meios de comunicação que encurtam a distância entre os espaços culturais. Essas interações deixam as identidades mais flexíveis e em constante transformação.

O interesse por compreender esse indivíduo é um grande desafio, principalmente, por se tratar de uma tentativa de entendermos a nós mesmos. Desde as civilizações mais antigas, essa curiosidade se faz presente no imaginário humano. A literatura, enquanto uma arte de representação humana por meio do código linguístico, é considerada uma das mais importantes formas de interpretação da realidade e do imaginário, atualizando-se ao longo da história. Por isso, trata-se de uma literatura de caráter realista, regionalista, modernista, hipermoderna, pois ela é um reflexo de cada sociedade em seu tempo. 
Desde as semi-eruditas modinhas imperiais até a manifestação do rock nacional, passando pelo Tropicalismo e pela Bossa-nova, a canção foi escolhida como objeto e veículo de manifestação do pensamento e discussão de questões culturais, políticas e econômicas da sociedade brasileira. Ao longo da história, a canção tem ganhado a atenção não apenas de compositores e músicos, mas também de críticos e acadêmicos devido à sua especialidade poética que desmistifica, a partir de um entre lugar discursivo que se reveza entre o real e o imaginário, as normas e os valores culturais que foram úteis enquanto referência.

Reconhecidamente um dos maiores representantes da música brasileira, Chico Buarque é um compositor que agrega apuro rítmico e melódico, além da qualidade e requinte das letras. No início da sua carreia foi considerado "a única unanimidade nacional" de acordo com o jornalista Millôr Fernandes. A primeira imagem de "bom moço", logo é ultrapassada quando em 1968 a peça Roda viva é encenada. Nos anos de 1970, torna-se figura emblemática de resistência à ditadura, sendo um dos artistas mais perseguidos pela censura. Temos, portanto, duas imagens que marcam o compositor: a do moço tímido e afetuoso, e a de indivíduo engajado, imerso na problemática política e social do seu tempo. Um artista envolvido com a palavra muito bem elaborada e com a sociedade sempre retratada de maneira profunda e penetrante.

O traço melancólico da obra de Chico Buarque, apontado pela instigante mistura de prazer e dor, pode ser relacionado ao admirável e profícuo diálogo do compositor com a tradição. Em 1973, em um dos primeiros ensaios significativos sobre a obra de Chico Buarque, Affonso Romano de Sant'Anna fez o seguinte comentário: "Em Chico a música é possibilidade de comunhão, a lembrança do paraíso perdido, música como abertura para vida". Essa recorrente sensação de nostalgia, de utopia revela o descompasso entre o artista e a realidade ideológica que o envolve. $\mathrm{O}$ nascimento de um "momento de exceção", de uma utopia está relacionado à desarmonia entre o sujeito e a realidade disponível.

Observa-se nessa pesquisa o interesse do artista em apreender o tempo atual, já que, como foi demonstrado, suas composições evidenciam a capacidade de adaptar para a literatura os reflexos do cenário contemporâneo e o descentramento em que vive o sujeito hiper. A contemporaneidade de Chico não se restringe à sua arte, mas a ele mesmo, observada a extensão nas diversas áreas artísticas nas quais atua - música, 
teatro, literatura: um homem em constante construção, reinventando-se e enriquecendo a arte brasileira.

A partir dos anos de 1980, revoluções nos nossos hábitos e comportamentos, possibilitaram o domínio crescente do hipermoderno. $O$ fim da guerra fria e o surgimento de um mundo bipolar, o intenso crescimento da globalização liberal, além do incremento das novas tecnologias da informação, tiveram importante papel nesse processo. A hipermodernidade é, assim, o tempo dos excessos, da complexidade, do consumo e do individualismo pensados sob a lógica do "hiper". Por hipercomplexidade pode-se entender uma sociedade liberal regida por uma lógica paradoxal: num mesmo espaço coexistem, de um lado, a crispação, a reação, o retorno a uma tradição reciclada pela lógica da modernidade e, por outro lado, o movimento, a fluidez, a flexibilidade, o desapego diante dos modelos estruturais da modernidade (como a nação, o Estado, a religião, a família, a política).

A necessária reconstrução do vínculo entre indivíduo e comunidade se torna, desse modo, complexa devido ao enfraquecimento dessa relação, hoje imersa na lógica mercantil que desfaz os laços coletivos e conduz o sujeito a privilegiar a esfera privada. Chega-se ao estágio em que a comercialização dos modelos de vida não encontra mais nenhum obstáculo estrutural, cultural ou ideológico, o sujeito é conduzido a pensar todas as relações sociais sobre a ótica das relações de produção e consumo: se consome para obter prazer, busca-se um sentimento de satisfação constante num mundo entregue à fugacidade das coisas.

À medida que assiste-se à perda da legitimidade da metanarrativa fundadora da narrativa da própria modernidade, observa-se o aumento das críticas contra a radicalização, as exigências de flexibilidade e adaptação, ao modelo de curto prazo e do imprevisível. Ao negar sua condição, o indivíduo toma o caminho oposto buscando o mundo tranquilizador da tradição.

Esse retorno revigorado do passado compõe uma das facetas do hiperconsumo experiencial: além do conforto material, vende-se e compra-se resquícios de emoções, lembranças que evoquem um tempo considerado mais esplendoroso. A lógica mercantil invade o território da memória, acrescentando ao valor de uso e ao valor de troca, o valor emotivo vinculado aos sentimentos nostálgicos.

No entanto, ainda deve-se lembrar que a vida cotidiana é, mais do que nunca, movida pela lógica cambiante do presente. Socialmente, o passado não mais é 
instituidor nem estruturante. Ele apresenta-se renovado, reciclado ao agrado do mundo hiper, explorado com fins comerciais. Hoje, a tradição não convida à repetição, à fidelidade e à revivescência das coisas inalteráveis, ela mesma se recriou como um produto de consumo nostálgico ou folclórico, referência do passado para fins estéticos, emocionais e lúdicos. Enquanto o passado nos seduz; o presente e suas normas constantemente atualizadas governam nosso cotidiano.

Isso posto, essa pesquisa investigou os recursos poéticos de representação da sociedade hipermoderna na lírica buarqueana, pontualmente em canções selecionadas do seu último álbum Chico (2011), e a presença de marcas da contextualidade histórica, social e política do Brasil nas canções de Chico Buarque. Essas canções, enquanto parte do projeto poético brasileiro, seguem a tendência dos poemas contemporâneos que transitam num espaço de discursos diversos onde uma infinidade de temáticas reservam questões existenciais acerca da formação da identidade do sujeito a partir da relação com o Outro. Apesar do fragmentado contexto, o sujeito, aturdido em meio ao caos e velocidade das transformações de seu tempo, segue disposto a conhecer mais as próprias limitações de sua condição humana na tentativa de superar-se e reconstruir-se sob bases mais conscientes.

Chico inaugura um novo estágio na obra do compositor. Entendendo que a letra poética pode reverter o processo de afastamento/separação, redimensionando o processamento da realidade contemporânea, nesse último álbum, Chico Buarque recorre à memória, seja a memória poética da lírica de suas composições passadas ou as memórias da sua própria experiência existencial, como matéria das letras das canções, o que atualiza e alinha sua obra ao contexto hipermoderno vivido no século XXI.

Viu-se esse panorama nos encontros dos sujeitos poéticos em "Nina", que se dão por meio da Internet, na desordem do espaço urbano e das relações pessoais ("Querido diário") e no apelo à valorização das lembranças memoráveis em meio à confusão mental da atualidade ("Barafunda"). Observou-se em "Barafunda" que esse tumultuado processo de construção e desconstrução das lembranças agrega ao legado lírico as lembranças memoráveis no presente e isolam as imemoráveis com o esquecimento. $\mathrm{O}$ mesmo ocorre com a memória poética. Em Chico as memórias do momento de luta e violência do passado, de engajamento artístico das décadas de 1960 e 1970, ficam retidas no esquecimento da memória poética. A maturidade torna o poeta um sujeito pacífico, que retira a carga dramática das canções dos tempos políticos. Contudo, o 
sujeito Chico Buarque do século XXI, não é passivo. De acordo com Silva (2013), ele segue engajado enquanto observador e crítico dos novos tempos, fazendo uso da memória poética nas canções de Chico. O artista reinterpreta e transfigura imagens, gêneros, discursos, linguagens artísticas, atualizando os diversos sentidos da sua obra, no intuito de revelar uma outra faceta do seu projeto poético de criação.

Entre o tempo acelerado e o tempo redescoberto, as canções de Chico Buarque continuam a representar com certa nostalgia o imaginário humano. Agora é a vez do múltiplo e fragmentado sujeito hipermoderno buscar sua completude, e torcemos (atualizando o Carlos Drummond de Andrade de 1966) para que "nunca uma banda como essa deixe de musicalizar a alma da gente". 


\section{REFERÊNCIAS}

ADORNO, Theodor. Discurso sobre lírica y sociedad. In: Notas de literatura. Barcelona: Ariel, 1962.

ANDERSON, Perry. As origens da pós-modernidade. Rio de Janeiro: Jorge Zahar, 1999.

BACHELARD, Gaston. A Poética do Espaço. In: Os Pensadores XXXVIII. 1. ed. São Paulo: Abril Cultural, 1974.

BAKHTIN, Mikhail. Estética da criação verbal. São Paulo: Martins Fontes, 2003.

BAUDELAIRE, Charles. As multidões. In: Le Spleen de Paris. Paris: Livre de Poche, 1972.

BAUMAN, Zygmunt. Amor líquido: sobre a fragilidade dos laços humanos. Rio de Janeiro: Jorge Zahar, 2004.

Janeiro: Zahar, 2011.

44 cartas do mundo líquido moderno. Tradução Vera Pereira. Rio de

BOSI, Alfredo. O ser e o tempo na poesia. São Paulo: Companhia da Letras, 2001.

CALVINO, Italo. Seis propostas para o próximo milênio: lições americanas. Trad. Ivo Barroso. São Paulo: Companhia da Letras, 1990.

CANDIDO, Antonio. O direito à literatura. In: Vários escritos. $3^{\mathrm{a}}$ ed. São Paulo: Duas Cidades, 1995.

CARVALHO, Cláudia Constante. Identidade e intimidade: um percurso histórico dos conceitos psicológicos. In: Análise Psicológica, no 4, ano XVII, Lisboa, 1999. p. 727741.

CHARLES, Sébastien. Cartas sobre a hipermodernidade. Tradução Xerxes Gusmão. São Paulo: Editora Barcarolla, 2009.

CORRÊA, Patrícia Aparecida. Modernidade e Pós-Modernidade na canção popular brasileira urbana: a voz ativa de Chico Buarque de Hollanda. 2009. 103 f. Dissertação (Mestrado em Literatura brasileira) - Instituto de Letras, Departamento de Teoria Literária e Literaturas. Universidade de Brasília, Brasília, 2009.

CYNTRÃO, Sylvia Helena. Como ler o texto poético: caminhos contemporâneos. Brasília: Plano Editora, 2004.

- Cultura contemporânea: a redefinição do lugar da poesia. In: Poesia: o lugar do contemporâneo. Sylvia Helena Cyntrão (org.). Brasília: Universidade de Brasília, Departamento de Teoria Literárias e Literaturas, 2009. p. 47-50. 
O que será que lhe dá?/ O que será que me dá?/ O que será que dá dentro da gente?: Tradução da tradição amorosa na canção de Chico Buarque. In: Chico Buarque: o poeta das mulheres, dos desvalidos e dos perseguidos. Rinaldo de Fernandes (org.). São Paulo: LeYa, 2013. p. 363-372.

DA MATTA, Roberto. A casa e a rua. 5 ed. Rio de Janeiro: Rocco, 1997.

DIA Voa. Direção e Produção: Bruno Natal. Videograma, 2011. Documentário.

DINIZ, Júlio Cesar Valladão. A voz e seu dono: poética e metapoética na canção de Chico Buarque de Hollanda. In: Chico Buarque do Brasil: textos sobre as canções, o teatro e a ficção de um artista brasileiro. Rinaldo de Fernandes (org.). Rio de Janeiro: Garamond/Fundação Biblioteca Nacional, 2004. p. 259-272.

DURKHEIM, Émile. As regras do método sociológico. São Paulo: Martin Claret, 2002 [1907].

EAGLEATON, Terry. As ilusões do pós-modernismo. Rio de Janeiro: Jorge Zahar, 1998.

ECO, Umberto. Os limites da Interpretação. $2^{\mathrm{a}}$ ed. São Paulo: Perspectiva. 2004 [1990].

FONTES, Maria Helena Sansão. Sem fantasia: masculino-feminino em Chico Buarque. Rio de Janeiro: Graphia, 1999. Série Temas e Reflexões; VII.

GIDDENS, Anthony. As consequências da modernidade. São Paulo: UNESP, 1991.

. A transformação da intimidade. São Paulo: Editora UNESP, 1993.

HALL, Stuart. A identidade cultural na pós-modernidade. Rio de Janeiro: DP\&A Editora, 2005.

HOLANDA, Bartolomeu Buarque de. Buarque: uma família brasileira. Rio de Janeiro: Casa da Palavra, 2007.

HOLLANDA, Chico Buarque de. "Tenho medo de me tornar um idiota". O Estado de São Paulo. Caderno 2. São Paulo, junho/2005. Disponível em: <http://www.chicobuarque.com.br/texto/mestre.asp?pg=entrevistas/entre_caderno2_290 605.htm >. Acesso em: 09/09/2014.

. Tantas palavras. Todas as letras \& reportagem biográfica de Humberto Werneck. São Paulo: Companhia das Letras, 2006.

Entrevista concedida à revista Trip. São Paulo, abril/2006. Disponível em: 〈http://revistatrip.uol.com.br/144/chico/01.htm>. Acesso em: 26/08/2014.

"A dupla vida de Chico". Língua Portuguesa, São Paulo, nº 8, ano I,

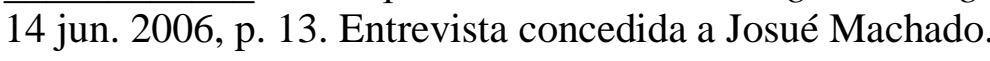


. "Podendo, vou até os 95". Revista Brazucaonline. São Paulo, abril/2010 . Disponível em: $<$ http://www.chicobuarque.com.br/texto/mestre.asp?pg=entrevistas/entr e_brazuca_0410.htm >. Acesso em: 04/09/2014.

. "Entrevista RS: Chico Buarque". Rolling Stone, São Paulo, Edição 61, Out. 2011. Entrevista concedida a Paulo Terron.

JAMESON, Fredric. A lógica cultural do capitalismo tardio. In: Pós-modernismo - A lógica cultural do capitalismo tardio. São Paulo: Editora Ática, 1997.

KELLNER, Douglas. Popular Culture and the Construction of Postmodern Identities. In: Modernity and Identity, Scott Lash and Jonathan Friedman (Eds.). Oxford: Blackwell Publishers, 1992.

KRISTEVA, Julia. Introdução à semanálise. São Paulo: Perspectiva, 1974.

LAPLANTINE, François; NOUSS, Alexis. A mestiçagem. Lisboa: Instituto Piaget, 2002.

LÁZARO, André. Amor: Do mito ao mercado. Petrópolis, RJ: Vozes, 1996.

LÉVY, Pierre. A Conexão Planetária: o mercado, o ciberespaço, a consciência. São Paulo: Editora 34, 2001.

LIMA, Brunna Guedes Marques de. A tradução da tradição amorosa do par romântico em canções selecionadas de Chico Buarque de Hollanda. 2010. 106 f. Dissertação (Mestrado em Literatura Brasileira) - Instituto de Letras, Departamento de Teoria Literária e Literaturas. Universidade de Brasília, Brasília, 2010.

LIPOVETSKY, Gilles. Os tempos hipermodernos. Trad. Mário Vilela. São Paulo: Editora Barcarolla, 2004.

SP: Manole, 2007.

Gilles. A sociedade da decepção. Trad. Armando Braio Ara. Barueri, ; SERROY, Jean. A cultura-mundo: resposta a uma sociedade desorientada. Tradução Maria Lúcia Machado. São Paulo: Companhia das Letras, 2011.

LYOTARD, Jean-François. $O$ pós-moderno. $3^{\text {a }}$ Ed. Rio de Janeiro: José Olympio Editora, 1988.

A condição pós-moderna. Lisboa: Gradiva, 1989.

LYRA, Pedro. "Benvinda" - Uma rara canção de amor feliz. In: Chico Buarque: o poeta das mulheres, dos desvalidos e dos perseguidos. Rinaldo de Fernandes (org.). São Paulo: LeYa, 2013. p. 271-287. 
MATHIS, Armin. A sociedade na teoria dos sistemas de Niklas Luhmann. Disponível em: <http://www.infoamerica.org/documentos_pdf/luhmann_05.pdf>. Acesso em: $31 / 03 / 2015$.

MENESES, Adélia Bezerra de. Desenho mágico: poesia e política em Chico Buarque. São Paulo: Hucitec, 1982.

. O artista e o tempo. In: Percurso - Revista de Psicanálise, ${ }^{\circ}$ 15. São Paulo: Departamento de Psicanálise do Instituto Sedes Sapientiae. 1995. p. 77-81.

. Lirismo e resistência. In: Revista CULT. São Paulo: Editora 17, 69: 54-59, 2003.

MOUTINHO, Marcelo. Rio de Janeiro em letra e música. In: In: Para ouvir uma canção. André Masseno; Tiago Barros. (org.). Caixa Cultural. Rio de Janeiro: Quintal produções artísticas. 2011. p. 54 - 63.

NESTROVSKI, Arthur (org.). Música popular brasileira hoje. São Paulo: Publifolha, 2002.

PAZ, Gaspar. Interpretação e canção popular. In: Para ouvir uma canção. André Masseno; Tiago Barros. (org.). Caixa Cultural. Rio de Janeiro: Quintal produções artísticas. 2011. p. $26-37$.

PEREIRA, Simone Luci. Escutando memórias: uma abordagem antropológica para o estudo da canção das mídias. In: Música e Mídia: novas abordagens sobre a canção. Heloísa de A. Duarte Valente (org.); Gil Nunes Vaz [et al.]. São Paulo: Via Lettera/Fapesp, 2007. p. 147-173.

PERRONE, Charles A. A força dos elos da "Corrente". In: Chico Buarque: o poeta das mulheres, dos desvalidos e dos perseguidos. Rinaldo de Fernandes (org.). São Paulo: LeYa, 2013. p. 91-98.

RAMALHO, Chistina. O híbrido lirismo brasileiro dos anos 90: injunções históricas, políticas e econômicas. In: Revista Cerrados, nº 18, ano 13, Brasília, 2005. p. 89-99.

RODRIGUES, Nelson. O óbvio ululante. São Paulo: Companhia das Letras, 1993.

ROSSI, Deise Mirian. $O$ amor na canção: uma leitura semiótico-psicanalítica. São Paulo: EDUC; Casa do Psicólogo; Fapesp, 2003.

SALLES, Paulo de Tarso. Aberturas e impasses: o pós-modernismo na música e seus reflexos no Brasil, 1970-1980. São Paulo: Editora UNESP, 2005.

SANT'ANNA, Affonso Romano de. Música popular e moderna poesia brasileira. Petrópolis: Vozes, 1978.

Chico Buarque: a música contra o silêncio. In: Chico Buarque do Brasil: textos sobre as canções, o teatro e a ficção de um artista brasileiro. Rinaldo de 
Fernandes (org.). Rio de Janeiro: Garamond/Fundação Biblioteca Nacional, 2004. p. 161-166.

SILVA, Anazildo Vasconcelos da. A poética de Chico Buarque: a expressão subjetiva como fundamento da significação. Rio de Janeiro: Sophos, 1974.

Quem canta comigo: representações do social na poesia de Chico Buarque. Rio de Janeiro: Garamond, 2010.

A lírica buarqueana. In: Chico Buarque: o poeta das mulheres, dos desvalidos e dos perseguidos. Rinaldo de Fernandes (org.). São Paulo: LeYa, 2013. p. 43-89.

SODRÉ, Muniz. Samba, o dono do corpo. Rio de Janeiro: Codecri, 1979.

SOUZA, Tárik de. Chico Burque - O que não tem censura nem nunca terá. In: $O$ som nosso de cada dia. Porto Alegre: L\&PM, 1983. p. 11-19.

TATIT, Luiz. O século da canção. Cotia: Ateliê Editorial, 2004.

TELLES, Lígia Guimarães. "Eu te amo": do amor à despedida. In: Chico Buarque: o poeta das mulheres, dos desvalidos e dos perseguidos. Rinaldo de Fernandes (org.). São Paulo: LeYa, 2013. p. 169-173.

VALENTE, Heloísa de A. Duarte. Canção artística, canção popular, canção das mídias: movência e nomadismo. In: Música e Mídia: novas abordagens sobre a canção. Heloísa de A. Duarte Valente (org.); Gil Nunes Vaz [et al.]. São Paulo: Via Lettera/Fapesp, 2007. p. 79-97.

VARGAS, Herom. O hibridismo e a mestiçagem como instrumentos para o estudo da canção na América Latina. In: Música e Mídia: novas abordagens sobre a canção. Heloísa de A. Duarte Valente (org.); Gil Nunes Vaz [et al.]. São Paulo: Via Lettera/Fapesp, 2007. p. 61-78.

VAZ, Gil Nuno. O campo da Canção: um modelo sistêmico para escansões semióticas. In: Música e Mídia: novas abordagens sobre a canção. Heloísa de A. Duarte Valente (org.); Gil Nunes Vaz [et al.]. São Paulo: Via Lettera/Fapesp, 2007. p. 11-49.

VATTIMO, Gianni. O fim da modernidade: niilismo e hermenêutica na cultura pósmoderna. São Paulo: Martins Fontes, 1996.

WILLIAMS, Raymond. Cultura. Rio de Janeiro: Paz e Terra, 1992.

ZAPPA, Regina. Para seguir minha jornada: Chico Buarque. Rio de Janeiro: Nova Fronteira, 2011.

ZUMTHOR, Paul. Tradição e esquecimento. Tradução: Jerusa Pires Ferreira e Suely Fenerich. São Paulo: Hucitec, 1997. 
Escritura e nomadismo: entrevistas e ensaios. Tradução: Jerusa Pires Ferreira e Suely Fenerich. São Paulo: Ateliê Editorial, 2005.

Performance, recepção, leitura. Tradução: Jerusa Pires Ferreira e Suely Fenerich. São Paulo: Cosac Naify, 2007.

\section{REFERÊNCIAS DISCOGRÁFICAS}

ANTUNES, Arnaldo. O silêncio. São Paulo: BMG, 1996.

GONZAGA, Luiz. Olha pro се́u. 78 RPM. Rio de Janeiro: RCA Victor Radio S. A., 1951.

; TEIXEIRA, Humberto. Baião. 78 RPM. Rio de Janeiro: RCA, 1949.

HOLlANDA, Chico Buarque de. Chico Buarque de Hollanda. Rio de Janeiro: RGE, 1966.

. Morte e Vida Severina. Rio de Janeiro: Philips, 1966.

. Chico Buarque de Hollanda. Vol. 2. Rio de Janeiro: RGE, 1967.

. Chico Buarque de Hollanda. Vol. 3. Rio de Janeiro: RGE, 1968.

. Chico Buarque de Hollanda. Compacto. Rio de Janeiro: RGE, 1968.

. Umas e outras. Compacto. Rio de Janeiro: RGE, 1969.

. Chico Buarque de Hollanda. Compacto. Rio de Janeiro: RGE, 1969.

. Chico Buarque na Itália. Rio de Janeiro: RGE, 1969.

. Apesar de você. Compacto. Rio de Janeiro: Philips, 1970.

. Per un pugno di samba. Rio de Janeiro: RCA/ RYM Musique, 1970.

. Chico Buarque de Hollanda. Vol. 4. Rio de Janeiro: CBD/Philips, 1970.

. Construção. Rio de Janeiro: Phonogram/Philips, 1971.

Quando o carnaval chegar. Rio de Janeiro: PolyGram, 1972.

1972.

. Caetano e Chico juntos e ao vivo. Rio de Janeiro: Polygram/Philips,

. Chico canta. Rio de Janeiro: Phonogram/Philips, 1973.

Sinal fechado. Rio de Janeiro: Phonogram/Philips, 1974. 
Phonogram/Philips, 1975.

Chico Buarque e Maria Bethânia ao vivo. Rio de Janeiro: . Meus caros amigos. Rio de Janeiro: Phonogram/Philips, 1976.

. Cio da Terra. Compacto. Rio de Janeiro: Phonogram/Philips, 1977.

. Os saltimbancos. Rio de Janeiro: Phonogram/Philips, 1977.

. Gota d'água. Rio de Janeiro: RCA, 1977.

. Chico Buarque. Rio de Janeiro: Phonogram/Philips, 1978.

Ópera do malandro. Rio de Janeiro: PolyGram/Philips, 1979.

. Vida. Rio de Janeiro: PolyGram/Philips, 1980.

. Show $1^{\circ}$ de Maio. Compacto. Rio de Janeiro: PolyGram, 1980.

. Almanaque. Rio de Janeiro: Ariola/Philips, 1981.

. Saltimbancos trabalhões. Rio de Janeiro: Ariola, 1981.

. Chico Buarque en espanhol. Rio de Janeiro: PolyGram/Philips, 1982.

. Para viver um grande amor. Rio de Janeiro: CBS, 1983.

. O grande circo místico. Rio de Janeiro: Som Livre, 1983.

. Chico Buarque. Rio de Janeiro: PolyGram, 1984.

. O corsário do rei. Rio de Janeiro: Som Livre, 1985.

. Ópera do malandro. Rio de Janeiro: PolyGram, 1985.

. Malandro. Rio de Janeiro: PolyGram, 1985.

1986.

. Melhores momentos de Chico e Caetano. Rio de Janeiro: Som Livre,

. Francisco. Rio de Janeiro: Ariola/RCA, 1987.

. Dança da meia-lua. Rio de Janeiro: Som Livre, 1988.

. Chico Buarque. Rio de Janeiro: RCA, 1989.

. Chico Buarque ao vivo Paris Le Zenith. Rio de Janeiro: RCA, 1990. 
Paratodos. Rio de Janeiro: BMG/RCA, 1993.

. Uma palavra. Rio de Janeiro: BMG/RCA, 1995.

. Terra. São Paulo: Companhia das Letras, 1997.

. Álbum de Teatro. Rio de Janeiro: BMG, 1997.

Chico Buarque de Mangueira. Rio de Janeiro: BMG/RCA, 1997.

As cidades. Rio de Janeiro: BMG, 1998.

. Chico ao Vivo. Rio de Janeiro: BMG, 1999.

. Chico e as cidades. DVD. Rio de Janeiro: BMG, 2001.

. Cambaio. Rio de Janeiro: BMG, 2001.

. Box Chico Buarque - Construção. São Paulo: Universal Philips, 2002.

. Chico Buarque - Duetos. Rio de Janeiro: BMG, 2002.

. Chico ou o país da delicadeza perdida. DVD. Rio de Janeiro: BMG,

2003.

. Box Francisco. CDs e DVDs. Rio de Janeiro: BMG, 2004.

. Chico no cinema. São Paulo: Universal Music, 2005.

Box Chico. Vol. 1. DVDs. Rio de Janeiro: EMI, 2005.

Box Chico. Vol. 2. DVDs. Rio de Janeiro: EMI, 2005.

Box Chico. Vol. 3DVDs. Rio de Janeiro: EMI, 2005.

Box Chico. Vol. 4. DVDs. Rio de Janeiro: EMI, 2006.

. Carioca. Rio de Janeiro: Biscoito Fino, 2006.

. Carioca ao Vivo. Rio de Janeiro: Biscoito Fino, 2007.

. Carioca ao Vivo. DVD. Rio de Janeiro: Biscoito Fino, 2007.

. Chico Buarque Essencial. Rio de Janeiro: Sony/BMG, 2008.

. Chico. Rio de Janeiro: Biscoito Fino, 2011.

. Na carreira. CD Duplo e DVD. Rio de Janeiro: Biscoito Fino, 2012. 
JOBIM, Tom. Caymmi visita Tom. Rio de Janeiro: Elenco, 1965.

SCIENCE, Chico. Afrociberdelia. São Paulo: Sony, 1996.

VELOSO, Caetano. Caetano Veloso. São Paulo: Philips, 1967. 
ANEXOS

\section{Correio da Manhã - Carlos Drummond de Andrade - 14/10/66}

O jeito, no momento, é ver a banda passar, cantando coisas de amor. Pois de amor andamos todos precisados, em dose tal que nos alegre, nos reumanize, nos corrija, nos dê paciência e esperança, força, capacidade de entender, perdoar, ir para a frente. Amor que seja navio, casa, coisa cintilante, que nos vacine contra o feio, o errado, o triste, o mau, o absurdo e o mais que estamos vivendo ou presenciando.

A ordem, meus manos e desconhecidos meus, é abrir a janela, abrir não, escancará-la, é subir ao terraço como fez o velho que era fraco mas subiu assim mesmo, é correr à rua no rastro da meninada, e ver e ouvir a banda que passa. Viva a música, viva o sopro de amor que a música e banda vem trazendo, Chico Buarque de Hollanda à frente, e que restaura em nós hipotecados palácios em ruínas, jardins pisoteados, cisternas secas, compensando-nos da confiança perdida nos homens e suas promessas, da perda dos sonhos que o desamor puiu e fixou, e que são agora como o paletó roído de traça, a pele escarificada de onde fugiu a beleza, o pó no ar, na falta de ar.

A felicidade geral com que foi recebida essa banda tão simples, tão brasileira e tão antiga na sua tradição lírica, que um rapaz de pouco mais de vinte anos botou na rua, alvoroçando novos e velhos, dá bem a ideia de como andávamos precisando de amor. Pois a banda não vem entoando marchas militares, dobrados de guerra. Não convida a matar o inimigo, ela não tem inimigos, nem a festejar com uma pirâmide de camélias e discursos as conquistas da violência. Esta banda é de amor, prefere rasgar corações, na receita do sábio maestro Anacleto Medeiros, fazendo penetrar neles o fogo que arde sem se ver, o contentamento descontente, a dor que desatina sem doer, abrindo a ferida que dói e não se sente, como explicou um velho e imortal especialista português nessas matérias cordiais.

Meu partido está tomado. Não da ARENA nem do MDB, sou desse partido congregacional e superior às classificações de emergência, que encontra na banda o remédio, a angra, o roteiro, a solução. Ele não obedece a cálculos da conveniência momentânea, não admite cassações nem acomodações para evitá-las, e principalmente não é um partido, mas o desejo, a vontade de compreender pelo amor, e de amar pela compreensão.

Se uma banda sozinha faz a cidade toda se enfeitar e provoca até o aparecimento da lua cheia no céu confuso e soturno, crivado de signos ameaçadores, é porque há uma beleza generosa e solidária na banda, há uma indicação clara para todos os que têm responsabilidade de mandar e os que são mandados, os que estão contando dinheiro e os que não o têm para contar e muito menos para gastar, os espertos e os zangados, os vingadores e os ressentidos, os ambiciosos e todos, mas todos os etcéteras que eu poderia alinhar aqui se dispusesse da página inteira. Coisas de amor são finezas que se oferecem a qualquer um que saiba cultivá-las, distribuí-las, começando por querer que elas floresçam. E não se limitam ao jardinzinho particular de afetos que cobre a área de nossa vida particular: abrange terreno infinito, nas relações humanas, no país como entidade social carente de amor, no universo-mundo onde a voz do Papa soa como uma trompa longínqua, chamando o velho fraco, a mocinha feia, o homem sério, o faroleiro... todos que viram a banda passar, e por uns minutos se sentiram melhores. $\mathrm{E}$ se o que era doce acabou, depois que a banda passou, que venha outra banda, Chico, e que nunca uma banda como essa deixe de musicalizar a alma da gente. 


\section{Entrevista com Chico Buarque. O Estado de São Paulo/Caderno 2 - 29/06/05}

"Tenho medo de me tornar um idiota" - Ima Sanches La Vanguardia

Aos 60 anos, Chico Buarque fala sobre ser escritor e músico, considera oca a fama de sexy e rejeita o título de ícone

"Tenho 60 anos. Nasci e vivo no Rio. Estou separado e tenho três filhas, duas netas e meia, e um neto: Chico. Sou um democrata que ainda acredita na possibilidade de um socialismo democrático. Já tivemos quase duas décadas de idiotice globalizada. Sou ateu. Público Budapeste na Salamandra em castelhano e na La Magrana em catalão."

Uma vida rodeado de mulheres.

Sim, irmãs, filhas, netas.

O que aprendeu com elas?

Continuo com a curiosidade intacta, com o mesmo desconhecimento e esta estranha admiração. Sempre me surpreendem e suas opiniões me interessam mais que a dos homens.

Você encabeça a lista dos homens mais sexys do Brasil.

Isso é ridículo, e essa lista é ridícula. Tenho 60 anos, percebe?

Sempre fugiu da fama?

Não, participei de festivais e busquei o reconhecimento para meu trabalho. Mas logo aparece a fama boba, oca, que é a sombra do reconhecimento e que fala se o artista está gordo ou com quem vai para a cama. Há 40 anos não era assim.

Como era?

Ficávamos bêbados em Ipanema dizendo coisas absurdas, mas não saía na imprensa. Hoje, alguém vai ver uma partida de futebol e vem o jornalista lhe perguntar como está a partida. Isso não me agrada.

Mas é o que vende.

Tem gente que persegue essa fama que não corresponde a nada. É insólito.

Por que teremos chegado a esse ponto?

Nunca vi um movimento geral de idiotice como o de agora. Mas em meu país, de 15 anos para cá, vem crescendo perigosamente. A idiotice nos rodeia, eu mesmo tenho medo de me tornar idiota...

Pense bem...

Talvez tenha razão. Tudo seria mais fácil, nada me surpreenderia e poderia dar entrevistas sem escrever livros.

$? \ldots$

Sim, sim, anuncio que vou escrever um novo livro e passo dois anos dando entrevistas. Depois falo do livro que não saiu. E assim passa a vida. Hoje é possível viver de feira 
literária. Há festivais a cada semana em alguma parte do mundo. E agora que finalmente sou escritor...

Custou-lhe três livros.

Sim. Agora já me consideram como tal e posso viver me fazendo de turista literário; certamente conseguiria ser muito mais conhecido como escritor do que sou hoje sem necessidade de escrever mais livros.

Falemos de épocas mais intensas.

Não sou nostálgico, não penso que éramos mais bonitos, mais magros e mais felizes, embora tudo isso seja verdade. Não me agrada recordar nem os anos 60 nem os 70, dos 80 não me lembro, e nos 90 começou a idiotice. Nunca estive de acordo com o que me cercava. Me agrada estar vivo, fazer as coisas em meu ritmo, sem pressões.

Então deve ter vivido infeliz na ditadura.

Em fins de 68 começou a verdadeira censura e a perseguição aos opositores do regime, políticos, simples artistas ou fumadores de maconha. Isso tudo era preciso combater e nós, os artistas mais populares, o fizemos com a música, com prejuízo para a qualidade artística.

Você vivia sendo preso.

Como todos, mas saía sempre. Só dormi na prisão quando era menor de idade e roubava carros.

Um filho de ilustre historiador e sociólogo roubando carros?

Sim, roubávamos carros para circular pela cidade e quando acabava a gasolina os largávamos. No dia seguinte fazíamos o mesmo, assim até que me pegaram. Mas durante a ditadura me chamavam ou vinham me buscar e me levavam para perguntar por que havia cantado isso ou aquilo.

Chegou a ter medo?

Quem tem c... tem medo. Recebia ameaças, cartas. Hoje tem gente no Brasil que tem medo de outras coisas e vive cercada de guarda-costas, sobretudo os famosos, porque ter guarda-costas o torna ainda mais famoso.

Você é um ícone da música; poderia ter dois ou três.

Não me agradaria ser ícone, soa fatal. Chegaram a me chamar de monstro sagrado, que medo!

Para quem escreve as letras de suas canções?

São "cantadas" para mim mesmo: é formidável, experimente, diga-se coisas bonitas. Me lembro de Vinicius de Moraes, que quando viajava sozinho e tinha sonhos se cantava canções de ninar e passava a mão no rosto até adormecer. Eu tentei e não funcionou.

Você é um insone?

Sim, por isso sempre trabalho de noite, o que é fatal para o insone. Quando consigo dormir, escrevo música em sonhos. Compus coisas maravilhosas, mas logo percebi que eram de outros. 
Por que está há seis anos sem se apresentar?

Lancei o disco, fiz um ano de concertos, depois lançaram o disco do concerto do disco, e depois o disco do disco do concerto do disco... Em seguida colaborei em teatro, escrevi o livro e agora estou aqui com você.

Como é a sua mãe?

Tem 95 anos e repete constantemente, "Juízo e alegria!", e eu lhe digo: "Mamãe, ou juízo ou alegria." Meu pai era um sonhador e ela equilibrou seu lado boêmio, impunha a disciplina mas com muito sentido de humor, com isso: com juízo e alegria. Sete filhos!

O que significou para você trazer filhos ao mundo?

É formidável. Quando nasceu a primeira eu tinha 24 anos, era quase uma irresponsabilidade. Mas as três são melhores que seu pai e creio que se cada um de nós pudesse dizer isso, se Bush o dissesse, por exemplo, em 30 anos teríamos um mundo melhor.

\section{Entrevista com Chico Buarque - Revista Trip - abril/06}

Concentração em trem de Paris para Nancy, França: "Na hora de produzir você sai do zero, não do pódio. Quando vou escrever, não sou nada"

O telefone tocou passava da meia-noite. Do outro lado da linha, a inconfundível voz de um dos maiores nomes da música popular brasileira exclamou: "Descobri! É 'gestatório'!". Era a palavra que faltara em meio à entrevista realizada na véspera para se referir à liteira que serve para transportar o papa em ocasiões solenes: "Cadeira gestatória". Chico Buarque é um escritor e compositor obcecado pelas palavras. Uma obsessão que o persegue durante seu processo criativo. Avesso a religiões e outras crenças, suas bíblias são os volumes de dicionários; as orações, suas canções e romances. "Gestatório" tem, como primeira definição, "relativo a gestação"; e "gestar", no sentido figurado, é "trazer e levar palavras". O verbete tem tudo a ver com o inquieto personagem, que confessa sentir uma "sensação desagradável" quando está "parado", seja na música ou na literatura. Três anos após o lançamento do bestseller Budapeste e oito anos passados desde o lançamento de seu último CD, Cidades (1998) o estudante de arquitetura volta ao "urbanismo cultural" e põe na praça um disco chamado Carioca. Muito próximo de chegar aos 62 anos (no próximo 19 de junho), Chico também tem dificuldade em ficar fisicamente parado. Além de jogar peladas três vezes por semana no seu campo no Rio, defendendo as cores de seu time, o Polytheama, ele é um veterano caminhante. Em suas andanças pelo calçadão do Leblon e de Ipanema ou como um aplicado flâneur nas ruas de Paris, assobia novas melodias, cria versos e imagina o desenrolar das histórias de seus romances. Uma das dificuldades que enfrenta é quando o interrompem no meio do caminho: "Não posso dizer que estou trabalhando, porque ninguém vai acreditar. Então digo que estou me exercitando, que meu personal trainer está vindo atrás e não me deixa parar", diz, rindo.

$\mathrm{Na}$ tarde de uma quarta-feira da primavera europeia, no entanto, Chico Buarque permaneceu sentado numa cadeira da sala de seu apartamento em Paris por exatas duas horas e meia (com pausas para buscar água na cozinha ou ir ao banheiro) para falar ao gravador da Trip. A conversa, entre momentos mais graves e outros bem-humorados, discorreu sobre criação, música, literatura, política, futebol, mídia, arquitetura, psicanálise, sexo, drogas e hip hop. A seguir, os melhores momentos da entrevista. 
Nesta edição a Trip debate a importância que uma boa relação com o lugar em que moramos e com a nossa cidade tem para a felicidade de cada um. Você estudou arquitetura na USP. Você acha que teria sido feliz como arquiteto?

Eu sei que não seria um bom arquiteto. Às vezes fazia um trabalho de estagiário em escritório de arquitetura, e eu borrava tudo com nanquim, ficava uma porcaria. Eu não tinha gosto pela coisa técnica da arquitetura. Na verdade, não tinha talento para isso. Fui para a arquitetura por exclusão, não sabia para onde ir. Pensava "vou ser escritor". Mas não adianta estudar letras, tinha de ter urna profissão. Nenhum escritor vivia de ser escritor. Meu pai era professor, os outros escritores tinham outra profissão. A exceção clássica era o Jorge Amado. Eu não ia ser advogado, nem médico, nem engenheiro, nem administrador, e fui para arquitetura, que tinha alguma coisa a ver com arte. E naquela época tinha aquela empolgação, arquitetura era concorrida, muita gente moça queria ser arquiteta por causa de Brasília, de Oscar Niemeyer. E a escola era muito boa, os professores eram o Paulo Mendes da Rocha, o [Vilanova] Artigas e o meio universitário era estimulante. Foram bons anos ali, mas não por causa da arquitetura. Eu estudava em colégio de padres, e foi a primeira vez em que estudei em colégio público. Era outro mundo para mim.

Você largou a faculdade depois de 1964, quando o clima ficou chato...

O clima ficou muito chato mesmo. Não falo que larguei a faculdade por causa do golpe de 64, porque seria mentira. Cursei um ano de arquitetura em 1963. No segundo ano claro que a faculdade ficou chata, fecharam o grêmio, tudo ficou mais chato. Mas eu também já estava começando a fazer música. Quando me chamaram para fazer Morte e Vida Severina eu ainda era estudante da FAU. Em 1965, fiz um pouquinho e larguei pela música.

Teu último romance tem o nome de uma cidade e teu CD anterior se chama Cidades. De qual cidade você mais gosta e por quê?

Eu gosto do Rio de Janeiro, cidade onde nasci e moro, mesmo, há 40 anos. Fui com dois anos para São Paulo, estive em Roma, mas com 21 anos voltei para o Rio para fazer um show e fiquei. É a cidade onde sei morar melhor. Cidade não é só gostar, tem de saber morar.

Você já disse que durante muito tempo resistiu à ideia de ser carioca.

Eu sempre me senti carioca, o que acho meio chato é a coisa do bairrismo, de "ah, sou carioca". Não me sinto um carioca da gema, do chopp em bar, até já fiz isso muito. Mas essa coisa do cariocão não tem muito a ver comigo, da mesma forma que acho paulistice chata, baianice chata, mineirice chata.

\section{E São Paulo?}

É uma cidade onde não gostaria de morar. Mesmo porque a cidade hoje tem muito pouco a ver com a São Paulo da minha infância. Eu era criança e ia para o Rio todas as férias. E, além de ter a família, os primos, a praia, quando chegava no Rio tinha sempre a sensação de que estava chegando numa cidade grande. Quando chegava, geralmente um tio ia me buscar e eu vinha pela beira-mar vendo aqueles prédios todos, aqueles anúncios luminosos. Era uma coisa assim de estar chegando à capital, à metrópole. Quando voltava para São Paulo estava voltando para uma cidade de província, uma cidade quase de interior. A rua onde eu morava - que hoje é uma rua muito chique, 
cheia de lojas de grifes, a Taiarana, que virou a Vittorio Fasano [onde fica o hotel Fasano] - era uma rua de terra, a gente jogava futebol ali. Hoje vou para São Paulo e não conheço mais a cidade. Não sei andar em São Paulo. Se me derem um carro, não vou saber sair dirigindo.

É uma cidade que, hoje, você não aprecia?

Eu tenho laços afetivos com São Paulo, amigos lá, mas a cidade é um desastre. Era uma cidade amável nos anos 50, se podia gostar dela. Hoje em dia acho impossível alguém gostar. Estou falando da cidade, da arquitetura, do urbanismo. Se vai falar da vida noturna, cultural, dos restaurantes, hotéis, médicos, aí é muito boa. Mas a cidade é detestável. É um desastre, é a cidade que não deu certo. Lá no Rio, às vezes dá no noticiário "temporal em São Paulo", e aí vêm aquelas imagens da marginal. Não se pode ...viver assim, engarrafado.

Você costumava sonhar com cidades imaginárias. Ainda sonha?

Eu penso em cidades para dormir. Fico imaginando essas coisas, porque para pegar no sono tem de ficar inventando histórias. $\mathrm{O}$ único passo para você entrar no sono que eu conheço, a não ser que seja um sonífero, é a imaginação. Você cria um mundo e vai para lá. Tem uma hora que você percebe que está pegando no sono, e esse mundo começa a ficar meio solto, frouxo. Às vezes a gente já está dormindo, meio que acorda e fala "oba, já estou entrando no sono". E um desses pensamentos bons ou úteis, soporíferos, é a invenção de cidades. Aí chego na cidade, tem o aeroporto, a avenida. E desenhava cidades, algo que gostava muito de fazer, mas não tenho tido muito tempo. Qualquer hora posso voltar à ativa.

Você lembra e analisa seus sonhos?

Tenho uns sonhos de música que são engraçados. Descobri que não sou compositor nos meus sonhos. Eu componho músicas dos outros, mas ainda não parei para analisar por quê. Mas aconteceu uma série de vezes. Compus a música do meu bisavô, uma música inteira que existe [e cantarola "maré, maré]. Compus uma música do Sérgio Ricardo, era o "Samba da Biblioteca". E uma vez compus uma música do Zeca Pagodinho. E o mecanismo do sonho é formidável. Eu estava no palco, acho que no Canecão, e por algum motivo ia cantar uma música do Zeca Pagodinho. E eu dizia "droga, não estudei essa música, não sei nada, a música, a letra". E aí o conjunto começou a tocar e tinha um grupo de apoio, backing vocal, atrás de mim, que começou a cantar. E eu peguei a manha de ir ouvindo eles e cantando junto. Era uma coisa chamada "Samba de Roda". E aquele pânico, "como vou cantar essa música do Zeca Pagodinho, ninguém me ensinou, o que estou fazendo aqui no palco?". E tinha lá atrás o pessoal cantando "vai o samba de roda..." [canta]. Eu ia um pouquinho atrasado. E a plateia do sonho aplaudiu e tudo, não percebeu que eu estava enrolando. É engraçado isso. Eu podia compor uma música minha mesmo, acordar e, pá, o serviço já estava pronto [risos]. Seria mais fácil a vida, você dormir bastante, tendo sonhos musicais, acordava e ia direto para o estúdio gravar.

E você tem pesadelos?

Tenho [silêncio]. Tem uns sonhos assim que voltam. Tinha um que era muito bom, que faz tempo que não tenho, que era de voar. Faz alguns anos eu sonhei de novo que eu voava, e era tão bom, acordei tão feliz, "eu ainda sei voar". Voava, mas não como o Super-Homem ou o Capitão Marvel. Meu ídolo de infância era o Marvel. Minha primeira mulher, antes de as francesas mostrarem os peitos, era a Mary Marvel com 
uma sainha curta, que voava assim. Mas eu não voava como eles, não. No sonho era como se eu pulasse, como se não tivesse a lei da gravidade. Era como se a minha gravidade fosse menor, então eu podia abrir a janela e dar um pulo até aquele telhado ali, e se eu pousasse no chão e pegasse um impulso voava cada vez mais. Então não é voar, é flutuar. E bem alto, de ir até as nuvens e voltar. Era delicioso esse sonho. Eu tinha direto.

Como foi sua relação com a análise?

Não me dei bem com a psicanálise. Fiz três vezes e larguei as três. Uma acho que era junguiana, outra freudiana, nem lembro mais. Não gostei, não me dei bem. Antidepressivo nunca tomei. Remédio é só para dormir, em último caso. Evito me viciar nessas coisas. Tomo às vezes, quando preciso, um Dormonid. Mas se puder não tomo nenhum e bebo vinho. Com um vinho e mais uns placebos, umas besteirinhas, e mais umas ideias na cabeça eu consigo dormir. Mas é difícil. Eu prefiro evitar ficar dependente. Mas a seco não dá para dormir, simplesmente não dá, você deita e não consegue. Não sei como se faz para dormir.

Você já teve depressão?

Depressão, depressão, não. Talvez eu não seja a pessoa mais feliz do mundo, sei o que é angústia, mas não sou uma pessoa deprimida e nem dada a depressões. Angústia criativa eu sei o que é. Nas três vezes em que entrei para a psicanálise foi um pouco por isso, assombrado por um período de infertilidade criativa. Não conseguia fazer nada, e aquilo foi me angustiando, e aí entrava na análise. Por algum motivo, alguma hora eu começava a fazer música, mas não acredito que isso se devia à análise. Quando eu começava a fazer uma música ou algo assim eu me dava alta. Hoje lido melhor com isso. A experiência ajuda, você se diz "paciência, isso é normal". Você passa por períodos mais brilhantes e outros mais opacos.

Durante algum momento de sua vida já passou pela sua cabeça a ideia de se matar? Não, nunca. Gosto muito da vida, não quero morrer, não. Com tudo o que há, eu quero viver, viver bastante. E viver bem. No futebol eu já anunciei que eu iria pendurar as chuteiras em 2022. Anunciei no campo. Até vai ter uma festa, o pessoal quer fazer um churrasco. Mas isso já faz alguns anos, e agora estou achando que 2022 é cedo, vou estar com 78 anos. Estou com vontade de adiar um pouco [risos]. Você podendo fazer algumas coisas boas até mais adiante dá para viver.

Para você, o ato de criar é sempre algo misterioso, começa de um jeito e acaba de outro completamente inusitado. Foi assim também na criação deste novo disco?

É assim desde que comecei a alternar a música com a literatura. Quando volto a compor não sei mais como se faz para escrever uma música. O violão fica realmente encostado durante anos. A transição é difícil. Estava ainda mergulhado naquele mundo de literatura, queria sair dele, mas o violão custou a me atender. Quando você pega o violão de novo é como se não tivesse domínio do instrumento. É um pouco como você recomeçar um caso amoroso. É uma mulher que você não conhece, não sabe como lidar, no começo você faz muita cerimônia. E o violão ficava ali, arredio. Mas, quando a música começa a aparecer, ela é mesmo como uma namorada nova. Eu já estava com vontade de fazer música, com tesão musical mesmo. Então as músicas começaram a aparecer, e eram melodias e caminhos harmônicos novos para mim. Mas a letra demorou a aparecer, porque a cabeça ainda estava um pouquinho impregnada de 
literatura. E letra de canção não tem nada ou muito pouco a ver com literatura, é outro tipo de linguagem.

A cada disco você diz que essa inspiração misteriosa é confinada a um espaço mais estreito, menos fácil e espontâneo, como era há décadas.

Isso é natural. Você já seguiu muitos caminhos e quer fazer o que não fez ainda. Você começa a desconfiar quando tudo parece fácil, tem de abrir o olho. Não é uma esterilidade, mas uma vontade de procurar um caminho novo, original e, portanto, mais difícil. Você sempre pode descobrir coisas novas. Depois há um trabalho de depuramento que você começa a curtir mesmo. E é natural da, vamos dizer, terceira idade [risos] você se deter mais tempo na música, achar que sempre pode melhorar um pouquinho. Então cada canção leva um bocado de tempo para nascer, outro tanto para terminar e outro para burilar e chegar a forma final.

Você já falou sobre obsessões na hora de compor, imagens que te perseguem na hora da criação de uma música. Você teve obsessões neste disco?

É um trabalho obsessivo. E cada vez mais. Para você começar a escrever uma canção não precisa de um motivo forte. O motivo às vezes não é forte em si, mas acaba se tornando forte pela obsessão. "O que eu faço com isso? Tenho de fazer uma música." Mas você não sabe por que aquilo apareceu na tua cabeça. E você não vai sossegar enquanto não transformar em canção, em verso Eu lembro que a última música que fiz fiquei dois meses tocando, não vinha a letra, e era meio diferente, uma música meio espanhola. E acabou que não tem nada de espanhola. E ficava fazendo aquele desenho harmônico mil vezes por dia. Mudava uma coisinha no dia seguinte e regravava. É sempre uma coisa obsessiva. Trabalho obsessivamente.

Qual é a música?

A música se chama "Subúrbio".

E a música "Outros Sonhos".

Pois é, para você ver, tem coisas também que vêm lá de trás, e emergem. "Outros Sonhos" vem de um mote que meu pai cantava. A música acho que é chilena. Depois fui descobrir que os versos foram musicados por um autor chileno, mas também por um autor argentino. Tem um tango do Carlos Cardel que diz a mesma coisa. Enfim, estes versos são anônimos: "Soñe que el fuego hebala, soñe que la nieve ardia, y por soñar lo imposible, some que tu me querias". Meu pai cantava muito isso [repete os versos contando]. Cantava muito, só quando eu era garoto. Mas, de repente, volta. Volta e começa a ficar te perseguindo, e fica um "tenho de fazer esta música".

Você ainda teme que a música possa te abandonar um dia?

Já sublimei um pouco isso com essa coisa da literatura. Mas também não sei até quando vou levar isso. Parece um jogo perigoso porque vai acontecer. Quando este período de música passar, vou fazer shows e, depois, isso vai morrendo de morte natural. Aí imagino que vá querer escrever um novo livro e, evidentemente, não vou saber por onde. Não tenho ideia nenhuma, não penso isso. Não escrevo nada, tenho muita dificuldade para escrever. Escrever uma carta para mim é difícil, fico horas. Engraçado que antes de ouvir "Chega de Saudade", quando jovem, pensava que seria escritor.

Você vai fazer um aquecimento para a turnê num show em Berlim, como parte dos eventos culturais da Copa do Mundo, e vai aproveitar para assistir a dois jogos da 
seleção brasileira. Qual você acha que deve ser a composição do "quadrado mágico" do técnico Parreira?

Eu não entendo nada de futebol, nada de tática. Eu quero ver os melhores jogadores ali, todos juntos. Mas tem o Ronaldo e o Ronaldinho. Kaká está muito bem. Adriano não está muito bem, mas pode entrar. O Robinho acho ótimo. Acho que o Juninho Pernambucano também pode jogar. O Edmílson devia jogar também, porque avança. Eu gosto de jogadores que vão para frente. A defesa fica cheia de buracos, mas aí é problema do técnico. Eu não sei, não entendo mesmo, gosto de jogar e de ver. De ver jogadas criativas, ver gol, os passes, os dribles. Gosto menos de ver defesas brilhantes, beques que atrapalham as jogadas do ataque. Para mim eles atrapalham o espetáculo.

Por falar em espetáculo, a turnê de Carioca vai começar logo mais. Ainda é angustiante para você subir no palco?

Aí vem essa coisa que todo mundo fala "ah, porque é tímido, mas neste dia ele não tava tímido". Todo dia eu não estou tímido, mas eu sou tímido porque assim está escrito. "O tímido, o supertímido Chico Buarque neste dia se soltou." [Risos] Mas" ele" está se soltando todo dia. Eu não sou tímido na minha vida normal. Mas eu não acho que seja normal você subir no palco e cantar. Ali, realmente, travo um pouco. Não sei como vai ser o próximo. Espero não sofrer. Gosto dos ensaios, gosto de viajar com os músicos, a gente se diverte muito. Mas entrar no palco, uma estreia, quando penso agora fico um pouquinho apreensivo. Às vezes a boca fica seca. Sei lá, acontece mesmo de esquecer tudo. Mas ao longo da temporada vai melhorando.

O fato de ser um dos compositores mais importantes da música brasileira já influenciou na sua maneira de produzir? A responsabilidade atrapalha?

Não, porque na hora de produzir você sai do zero. Não sai do trampolim, do pódio. Você não está de salto alto. Você tem de estar descalço. As pessoas imaginam que o artista pensa nele o tempo todo. Que fica se olhando no espelho, se achando o máximo. E você age como uma pessoa normal, porque você se sente uma pessoa normal. E aí as pessoas dizem "tá lá o artista fingindo que é uma pessoa normal". Quando vou escrever, não sou nada.

Você acha que o tipo de música que faz, a "canção", está com os dias contados?

É um assunto interessante. Um jornalista na Itália me perguntou uma vez se a música popular não seria um fenômeno restrito ao século $2^{\circ}$, assim como a ópera tinha sido restrita ao século precedente. Há vários indícios. Também não estou querendo jogar contra mim Estou fazendo músicas novas e talvez sejam músicas tardias, não sei. Ou talvez eu já seja um sujeito tardio, do século passado. Mas é interessante, porque algumas coisas levam a acreditar nisso. É o caso da percussão em detrimento da harmonia e da melodia, do rap que é um pouco a negação da canção como a gente conhece. Também está proliferação de revivals, de coletâneas, de best of, esse anseio do público pelo velho, pelos standards. Seriam sinais de fim de linha da canção como modo de expressão? Talvez sejam, tomara que não. Mas aí já interpretaram mal, de uma forma um pouco malévola, como se eu estivesse dizendo que nós fomos das últimas gerações a compor, e agora vocês vão pegar esta sopa, e não vai ter música para vocês, não [risos]. Pode ser que exista uma maneira. O rap já é um pouco isso. Também, não sei se o rap vai continuar imperando, e amanhã podem dizer que o rap foi uma moda do começo dos anos 2000. 
Você escuta rap?

Eu até ouço às vezes. E até ouvi, por dever de ofício, quando pensei no rap para "Ode aos Ratos" [do musical Cambaio em parceria com Edu Lobo, e gravada no novo disco]. Depois desisti de fazer um rap, pensei "não, essa coisa já está um pouco vulgarizada, já está todo mundo fazendo, vejo até em anúncio de TV, não vou fazer rap, não". Mas aí fiz essa embolada, que é um pouco um rap, um pouco falada. Uma coisa já antiga, nordestina, mas que tem a ver com a divisão do rap.

E a música eletrônica, o que acha dela? Já dançou ao som de um DJ?

Não sou muito bom de dançar. Aliás, uma vez eu dancei, mas foi num lugar em que não era preciso dançar muito. Não sei o que era. A pessoa que estava comigo reclamou que não era tecno, que era house, ou que era house e não era tecno. Eu não entendia nada daquilo. Isso foi aqui em Paris. Mas as luzes piscavam e você não precisava dançar. Meio que mexia assim (faz o gesto), e você olhando de fora via algo como robôs dançando. Se é assim, então tá bom, você não precisa ser um Fred Astaire para brilhar na pista. Aí entrei, dei meus passos e tudo bem.

Você tem iPod?

Não, nem sei direito o que é isso. Eu ouço falar, mas não sou bom nisso. Não sei lidar muito bem com informática. Só sei o básico. Até hoje não consegui entender como se faz para gravar um CD. Tenho tudo lá em casa, mas aí quando fui fazer as músicas e tive de mandar para o Luiz Cláudio Ramos, que é o arranjador, tentei e não consegui. E aí recorri ao velho gravador cassete. Foi à moda antiga.

O telefone celular você usa pouco e de forma utilitária, mas a Internet se tornou parte de sua vida. Aqui em Paris e quando viaja eu sei que você frequenta cibercafés. Como é isso?

Frequento para saber notícias do Brasil, e sempre tem essa coisa de correspondência. Eu comecei a ter só por necessidade imperiosa, para troca de e-mails com os tradutores, quando começaram as traduções de Budapeste. Quando fiz Budapeste usava o computador como uma máquina de escrever, com o Word. Não tinha Internet. E aí passei a ter para isso, para o contato imediato. Antigamente, isso era feito por telefone, por fax, era complicado, e o e-mail facilita muito a vida. Mas também você perde um pouco de tempo ali. Antes, ficava jogando paciência, que era uma espécie de aquecimento dos dedos para começar a escrever. Durante todo o tempo em que fiz meu livro tinha esse ritual. E agora, em vez da paciência, tem o Google, sei lá, para fazer uma pesquisa, ver uma sacanagem.

E o que você acha do sampler no trabalho de criação musical?

Você está achando que vai me pegar, que eu não sei o que é sampler, né? (Risos). Mas eu sampleei uma vez, também não sou tão bobo assim, não. Foi numa música chamada "Tempo e Artista" [1993], em que eu queria um serrote. Tentaram localizar um cara que tocava serrote em São Paulo, mas parece que já tinha morrido. E a referência que tenho do serrote é a introdução de "Ne me quitte pás", do Jacaques Brel. E aí o que nós fizemos? Sampleamos a introdução de "Né me quitte pás". Nessa você não me pegou.

Ao colocar o ponto final em Budapeste, aqui em Paris você disse: "E agora? Tenho de arranjar outra coisa para fazer". Você está se sentindo assim depois de ter finalizado o Carioca ou ainda não deu tempo? 
Já está começando perigosamente. Porque dá um brancão, né? Não posso ficar parado, senão dá uma sensação desagradável. Eu me lembro que estava aqui em Paris quando cheguei, na minha cabeça, ao final do livro. Ele estava num ritmo muito lento, e sabia que vindo para Paris em um mês eu adiantaria. Porque num mês aqui eu escrevo quase o dobro do que escreveria no Rio. Você fica mais isolado. E lembro o dia em que estava andando à beira do Sena, e tem aquele pessoal que fica dançando ali no verão. Naquele ano, pelo menos, era mágico. São vários anfiteatros e cada um tem um gênero de música. O pessoal do hip hop aqui, e lá adiante tem o pessoal dançando música brasileira. E tem um meio caminho em que você está ouvindo uma coisa e vendo outra. É muito louco isso, estar ouvindo uma música percussiva, que ficou ali para trás, e vendo o pessoal dançando tango ali adiante. E eu ia passeando por ali com a cabeça noutro lugar, eu estava no livro. Era uma forma de distrair um pouco a vista, mas a cabeça estava trabalhando. E foi em um dia assim que descobri que tinha chegado ao final do livro. Aí eu parei e fiquei olhando o pessoal dançando um tango do Piazzolla. E aí me deu uma alegria e uma tristeza misturadas. Lembro que fiquei com os olhos marejados, emocionado com aquela dança, e ao mesmo tempo a cabeça dizendo "pô, terminou meu brinquedo já sei que meu livro tem um fim". E agora também, o disco estava pronto e vim para cá, e saí por aí ouvindo o disco, andando com esse fone. Não é um iPod e essas coisas, mas um velho walkman. Esse é um momento bom de curtir, porque é uma despedida também. Ontem já acordei um pouquinho de ressaca, "já não vai ser mais tão bom como antes" \{risos\}. Depois você entrega o disco e ele cai na vida, as pessoas vão ouvir, vão gostar ou não, e vão gostar disto ou daquilo, e você já não está mais vivendo aquilo.

Já passou pela sua cabeça trabalhar com outras pessoas para se aventurar em outros caminhos musicais?

Eu tenho impressão de que não faço tudo sempre igual \{risos\}. São 12 músicas, 12 canções bem diferentes. Com tratamento orquestral diferente para cada uma. Cada uma é uma história à parte, com exceção de duas músicas que são bem coladas, porque a temática é a mesma. Uma outra é continuação da outra. "As Atrizes" e "Ela Faz Cinema". Mas assim mesmo são bem diferentes. Uma é um choro-canção, outra é uma bossa nova.

Elas foram escritas no mesmo elã?

Não. Isso foi engraçado. Eu compus "As Atrizes" porque estava gravando aquela série de DVDs, vim gravar aqui em Paris, e surgiu o assunto de Paris na minha vida. E me lembrei daquele momento em que vim a Paris pela primeira vez. Era pequeno, tinha uns oito anos de idade, morava em Roma com toda a minha família. O maior impacto para mim naquela época foi ver mulheres com peitos de fora. Não digo mulheres inteiramente nuas, mas tinha fotos de mulheres de peitos de fora nas bancas de revista. Nós passeamos à noite pelo Moulin Rouge, perto de Pigalle, e naquelas casas noturnas e cabarés havia fotos de mulheres quase totalmente nuas. Eu nunca tinha visto nada parecido, nunca tinha visto peito na minha vida. Na verdade, só os das minhas irmãs, mas isso não contava, elas não tinham peito, eram mais novas do que eu. Então aquele menino ficou deslumbrado com aquela coisa. Mais tarde, vieram aqueles filmes franceses, que eram proibidos para 18 anos, mas que às vezes a gente, com jeitinho, conseguia, com 15, 16 anos, entrar no cinema e ver. Ver Martine Carol e aquelas atrizes francesas, e mais tarde a Brigitte Bardot, nuas. E só existia isso em filme francês. Então escrevi essa música em cima dessas reminiscências de infância e adolescência, das 
atrizes nuas que me deixavam de boca aberta. Depois, o Roberto de Oliveira [amigo de muitos anos e diretor da série de DVDs], que foi me enrolando e muito delicadamente me levando a fazer mais e mais programas, fez um sobre cinema, e disse "você não quer fazer uma música nova sobre cinema?". Musicalmente é outra coisa, mas é uma continuação, é o marmanjo já, que termina a outra música dizendo "com tantos filmes na minha mente, é natural que toda atriz, presentemente, represente muito pra mim". Esse é o mote, o estopim para a música seguinte, tanto é que quando termina a música há quase uma sugestão de ligação musical com a faixa seguinte, que é "Ela Faz Cinema", que é então já o adulto, que é vítima de uma mulher que só faz cinema.

Você comentava sobre essas mulheres peladas da sua infância. Sempre estudou em colégio de padre e teve essa educação católica bem rigorosa, primeira comunhão, crisma e...

É. Era no tempo em que a missa era em latim, e eu fui coroinha no colégio. Tinha a sacristia, e a gente roubava hóstia - não consagrada, que é pecado mortal - e às vezes um gole de vinho. Além de estudar latim, eu sabia ajudar na missa, sabia tudo.

Hoje você é religioso, tem alguma crença?

Não, nada. Sete anos em colégio de padre foi bom para não gostar muito de Igreja. Eu não gosto de nada, sempre achei meio esquisito. As minhas lembranças de Igreja hoje são sempre muito sombrias. Um dia, em Roma, minha mãe conseguiu uma audiência não particular, claro, mas uma audiência restrita, com umas 100 pessoas - para ver o papa. Quando apareceu o papa, o Pio 12, fiquei com um medo dele, daquele velho. Ficamos numa sala, e aquele cheiro de incenso que me enjoa, e esperando, esperando, e em pé. E a minha mãe, que é católica - meu pai, é claro, não estava ali -, levou os sete filhos para ver o papa de perto. Depois de sei lá quanto tempo, apareceu o papa numa... não sei como se chama esta cadeira, tem um nome em latim, depois eu vejo. E ele passando carregado pelos soldados da Guarda Suíça. Ele com aquela batina branca, sendo carregado, cheio de almofadas brancas, e aí minha irmã mais nova falou alto "a papa é folgada, não é?" [risos]. Foi a única coisa que me relaxou. Enfim, eu me afastei completamente da Igreja. Já perdi a fé lá na escola de padre.

Você diz, mesmo assim, ter tido uma experiência positiva no trabalho com a Organização de Auxílio Fraterno.

Isso era bacana. Eu tenho conhecidos, amigos, que são padres da igreja progressista, mas sempre achei meio esquisito. Não acredito muito que eles acreditem naquela coisa da Igreja, nos dogmas. Mas esse padre André, canadense, levava a gente para dar cobertor e sopa para mendigos ali na Estação da Luz. Lembro de chegar lá e os mendigos ficarem assustados. A gente ia chegando como se fosse se aproximando de índios. Esse padre era legal. Lembro que quando chegou lá só falava francês, e a gente achava legal porque ele jogava vôlei junto com os alunos. Eu comecei a ensinar português para ele. Tinha a manchete no vôlei, e eu dizia "ô, a punheta, padre, bonita a punheta" [risos]. Eu ensinei português para o padre e ele me ensinou a ver os mendigos na Estação da Luz. Mas hoje não tenho religião nenhuma, não gosto de religião.

No filme Vinicius você fala sobre um tempo em que as casas eram abertas para todos e existia uma passionalidade nas relações. Você sente saudades dessa boemia?

Não sinto falta, porque não sinto nostalgias. Não só havia casas mais abertas, como havia os bares. Na verdade, havia mais bares do que casas. A gente se encontrava nos 
bares, ficava no Antonio's, depois no Luna Bar. Vinicius, Tom, a gente ficava horas. Não sei como é que eu podia fazer outra coisa. Lembro de uma vez, a gente bateu o recorde. Chegamos no Antonio's ao meio-dia e pouco e saímos às 3h da manhã. Acabou, passou esse tempo. Eu sinto falta das pessoas. Mas não dá para recuperar isso.

Você acha que falta romantismo nos relacionamentos? O beijo e o sexo ficaram fáceis demais, perderam o valor da conquista, como você disse uma vez?

Isso já existia. No pós-pílula, anos 60 e tantos, já era assim. Eu não peguei isso na minha formação sexual, e é uma pena, gostaria muito de estar me formando sexualmente agora [risos]. Naquela época, as primeiras experiências sexuais já eram mais tardias do que hoje porque você tinha menos informação. Hoje, um garoto de dez anos está sabendo o um garoto de 15 daquela época não sabia. E a formação sexual se dava com prostitutas ou com empregadas domésticas, que faziam um pouco prostituição também. No meu caso foi isso, minha primeira mulher era uma empregada que dava... ela não dava, cobrava, baratinho até. Era a empregada de um amigo da turma que tinha essas liberalidades. A gente sabia, e tinha aquela fila [risos]. E depois, as prostitutas e tal. Namoro não chegava às vias de fato. Eu tive várias namoradas com quem rolava uma forma qualquer de sexo, mas incompleto. Já depois, nos anos 60, eu já com 20 anos começou uma certa liberação. Então, que bom que a questão é mais aberta, menos traumática, menos hipócrita. $\mathrm{O}$ que me preocupa é que às vezes parece que há um certo enfado, que não existe mais a vibração que existia pela própria facilidade com que as coisas são obtidas. Pode ser. Mas pode ser impressão minha.

O que há de melhor e pior entre ser casado e solteiro?

No meu caso, vivi casado 30 anos e estou há dez anos só. Não me sinto só, não sinto solidão. Mas também não sei se é um caso especial. Porque eu trabalho sozinho, e gosto de trabalhar. Então posso de estar acompanhado, mas certamente gosto de estar sozinho também. Há momentos em que eu quero estar sozinho.

\section{Você já tomou Viagra?}

Eu sou contra essa coisa de dependência, tenho medo disso. Não sou contra Viagra, não, porque provavelmente eu vá ter de recorrer a ele. O que eu acho um pouco preocupante é esta ideia de ter um Viagra sempre à mão para facilitar as coisas. E tem gente nova que toma por medo de fracassar. Isso pode se tornar um problema, você vai precisar de Viagra para ficar de pau duro sempre. Pode até fazer uma experiência, mas criar mais essa dependência... queria não. Não sei, estou falando isso hoje, amanhã pode ser diferente.

Você já brochou?

Claro que já. Todo mundo já brochou, menos o Ziraldo [risos]. Ele diz que nunca brochou. Isso faz tempo. As pessoas falam muitas coisas. Tem outro que falou que teve mil mulheres. Eu digo: "Bom, mas, então, não foi bom nunca, para comer mil". O cara não é velho, tem vinte e poucos anos, e comeu mil. Mesmo que tenha comido uma por dia... Não acho uma vantagem comer mil mulheres.

Você já foi cantado por homens?

Já fui cantado por homens. Não foi adiante [risos]. Eu achei graça até. Era garoto, recebi uma proposta mirabolante. Achei engraçado. Quando eu era garoto talvez achassem que 
eu pudesse ser veado, eu era um menino atraente. Mas nunca fui veado, não. Pensando bem, já faz muito tempo que não tem um homem que me faz uma cantada.

Como foi sua experiência com as drogas? Experimentou um pouco de tudo?

Não experimentei tudo. Nunca fui na heroína, nunca me piquei. Foi o básico: fumei, cheirei, tomei ácido. E larguei isso tudo. Na verdade nunca fui um bom maconheiro. Eventualmente posso até fumar. Por exemplo, já me foi recomendado para dormir, eu tenho esse problema de insônia. Mas não dá certo comigo. Não me dá leseira, nem larica. Me deixa excitado. Aí eu preferi a cocaína, mas parei também, parei há muito tempo. Maconha ainda posso eventualmente fumar aqui e ali, não vejo muito mal. Mas não sou adepto.

Você é a favor da legalização de alguma droga?

Sou. E cada vez mais. No Brasil, nos países pobres principalmente, a quantidade de vítimas que o tráfico de drogas faz é muito maior que a de vítimas das próprias drogas. No Brasil, no Rio de Janeiro, moleques de nove, dez anos já estão cheirando cocaína, porque manejam, vendem cocaína. Envolve às vezes uma quantidade muito grande de crianças, adolescentes, acaba com a vida dessa gente, morre gente pra burro. Fora a violência toda que o próprio tráfico vai desencadeando. É claro que você não pode pensar em liberar abertamente o consumo de drogas se não tiver um interesse internacional. Senão, cria-se um problema. Você pode ir a Amsterdã e fumar sua baga na e tal, mas não pode sair de lá com o negócio. Se produzissem legalmente cigarros de maconha, se fossem vendidos nas tabacarias, no Brasil, como aliás digo numa música, não vejo que o dano... quer dizer, haveria, claro, um problema de saúde pública, como com o cigarro, como com as drogas farmacêuticas, o consumo de álcool. Há pessoas que entram na viagem e podem virar maconheiros, se tornar inúteis, mas podem se tornar meros consumidores de maconha e ter uma vida completamente normal. Não há comparação com a quantidade de vítimas que o tráfico traz. E mesmo a cocaína. Cocaína é barra-pesada, eu não recomendo a ninguém. Antigamente se vendia cocaína em farmácia. Descriminalizar ou comercializar de alguma forma com assistência médica, com licença ou isso e aquilo, não sei como se chegar a isso. Certamente, há alguma maneira melhor do que permitir que se trafique, porque isso é permitido, todo mundo sabe que há conluio da polícia, e um tráfico aberto faz um número de vítimas muito maior.

Como é sua relação com a política hoje? Você já disse experimentar um certo fastio da política.

Não vejo grandes novidades na política. Nem vejo muito espaço para grandes mudanças, sinceramente. Já não alimentava grandes ilusões de grandes mudanças com o governo Lula. Achava bonito isso, de ele ser eleito. Bom para o país um operário ser eleito e chegar à presidência da República. Mas também não achava que íamos ter transformações profundas na sociedade. É difícil. E agora ficou provado que é mais difícil até do que se imaginava.

A crítica da imprensa já te incomodou no passado, ao ponto de afetar sua produção. Como você lida com isso hoje?

Isso teve mesmo. Nos anos 80 foi barra-pesada. Você cansa, né? Tomando muita porrada, você vai perdendo a vontade de se expor a mais porrada. Eu tinha de ler o Jornal do Brasil com capacete, porque tinha porrada em tudo que era seção. Até a seção 
de gastronomia dava porrada. A Folha de S. Paulo, numa época, também era uma coisa barra-pesada. Isso, durante uns dez anos, foi muito chato. Principalmente uma certa imprensa paulista muito, muito agressiva. Depois melhorou um pouco. Hoje, não sei. Às vezes tenho a intuição de que algo está se armando [risos], que estão ali atrás, na esquina, espiando, "ele vai passar agora", prontos para dar porrada. Mas as porradas também com o tempo vão doendo menos, você vai ficando um pouco mais calejado.

Você pensa na velhice, sente ela chegar?

Ela vai chegando, vai se instalando aos poucos, tem umas coisinhas que você vai percebendo, uma mazelazinha ali que não tem jeito, é assim mesmo. Mas não estou me queixando, não.

Você tem medo da morte?

Medo não, mas quero distância [risos]. Acho que com saúde, fazendo as coisas direito, dá para viver um bocado mais. Gostaria de viver com saúde e imaginação, com vontade de criar coisas. Noventa e tantos anos e virando a noite por causa de uma música, um livro. Formidável. Posso morrer assim.

O Tom Jobim disse que "a gente só leva da vida a vida que a gente leva". O que você levará da sua vida?

Não vou levar nada. Alguma coisa deixarei. Umas musiquinhas, uns livros, filhas, netos. Vou deixar umas coisas bonitas. Coisas que valeram a pena.

\section{Entrevista com Chico Buarque - Revista Língua Portuguesa - junho/2006}

\section{A dupla vida de Chico}

Ele mostra mais uma vez que se move com desenvoltura de craque nos campos paralelos da música e da literatura

Chico flutua no campo de futebol, a bola colada aos pés, como se reencarnasse Pagão, o refinado centro-avante que jogou ao lado de Pelé antes que surgisse Coutinho. Por alguns toques e deslocamentos, lembra outro atacante que admira, Hidegkuti, da magnífica seleção húngara de 1954. E em certos momentos, por alguns toques e passes sutis, poderia ser confundido ora com Zico, ora com Ronaldinho Gaúcho.

São coisas do futebol e da história do futebol, uma das paixões a que Chico se entrega três vezes por semana, sempre que possível. Almoça frugalmente em seu apartamento no Leblon e segue com o amigo, produtor e escudeiro, Vinicius França, para seu campinho no Recreio dos Bandeirantes, quando está no Rio. Quando não está, procura um campo para matar a insopitável fome de bola.

Pois o futebol que Chico gostaria de jogar, com o tempero desses craques históricos e lampejos de Pelé, lembra sempre o refinamento e a sutileza das letras de suas canções, essas, sim, de craque consumado. O maior dos craques.

Tal habilidade, sutileza e refinamento aparecem de novo no recém-lançado disco, Carioca, que pode ser acompanhado do DVD Reconstrução, sobre os bastidores da gravação. Seu disco anterior, As Cidades, é de 1998. Entre um e outro disco, lançou em 2003 o romance Budapeste, depois de ter escrito Estorvo, Benjamim e algumas peças e musicais. 
É nesse campo, o artístico, que ele de fato desliza suave, às vezes flutua, magistral como ninguém. Esse é seu melhor campo. Nele circula feliz e se move com facilidade, apesar das agruras da criação. Move-se com tanta facilidade que, pelos resultados, nem parece ter tido o trabalho exaustivo de depuração que confessa ter. Trabalho de pesquisa, de mergulho interior, da busca permanente da melhor forma: "... reescrevo tudo inúmeras vezes". É de seu trabalho, de sua maneira de escrever e de suas preocupações que fala nesta entrevista.

Francisco Buarque de Holanda nasceu no Rio em junho de 1944 e passou a juventude em São Paulo, depois de uma estada e estudos em Roma, quando garoto, levado pela família: o pai, o historiador e sociólogo Sérgio Buarque de Holanda, foi adido cultural e professor em Roma em 1954 e 1955.

Em São Paulo, cursou colégios da cidade e o primeiro ano da Faculdade de Arquitetura e Urbanismo da USP. Foi em São Paulo também que se iniciou musicalmente ao participar dos festivais da década de 60. Era conhecido como "carioca", porque passava as férias no Rio, na casa de parentes, e tinha (e tem) sotaque carioquês. É o Rio que homenageia com seu último disco. Não só o Rio da zona sul, que sempre frequentou e onde mora, mas o da periferia. O Rio humilde pouco conhecido dos que visitam a cidade, que talvez continue maravilhosa. O Rio que não está nos mapas turísticos.

Língua - Desde o lançamento de seu disco anterior, você voltou a ter contato com o público em shows e, agora, no novo trabalho. O jovem de hoje recebe bem os artistas de sua geração?

Chico - Muita coisa mudou. As pessoas mais velhas relacionam as canções com momentos da própria vida, com fatos da época. Festivais, perseguições políticas, diferenças entre tendências musicais. Para os jovens, isso não existe. Um dia um deles disse que gostava muito de uma de minhas canções, Com Açúcar, com Afeto, que já tem 40 anos! Tenho impressão de que para a maioria deles sou um músico de um passado talvez sem nuances. Mas eles gostam das músicas. A maioria gosta. E olha que em certo momento já fui considerado completamente ultrapassado por alguns. Depois o interesse voltou. Pode ser que daqui a algum tempo percam de novo o interesse. Mas eu sou teimoso. E, a esta altura, não preciso me preocupar com o sucesso imediato.

Você ficou famoso como músico, letrista. De vez em quando pára e dedica-se a livros. O que o leva a uma coisa e outra? São dois Chicos?

Comecei a escrever Estorvo após mais de um ano sem conseguir trabalhar com música. Provavelmente, o livro já estava se escrevendo desde algum tempo na minha cabeça. Imagino que a cabeça esteja sempre a trabalhar, mesmo ou sobretudo em períodos de aparente bloqueio criativo. Estorvo trata da questão da linguagem, da palavra. Resulta um pouco da minha curiosidade pela palavra, pela linguagem.

Nos tempos de escola, você já desenvolvia essa curiosidade? Interessava-se muito pelo idioma? Estudava além das obrigações escolares?

Sim. Mas nunca estudei além das obrigações escolares. Sempre tive bons professores e não fui péssimo aluno.

E agora? Consulta dicionários ou livros de referência sobre o idioma quando escreve?

Sempre. Consulto o Caldas Aulete, o Houaiss, o Dicionário de Verbos e Regimes e o de Regimes de Substantivos e Adjetivos, ambos de Francisco Fernandes, e o Dicionário Analógico da Língua Portuguesa, de Francisco Ferreira dos Santos Azevedo. 
E o Aurélio, de seu tio, não?

(Rindo) Também, claro.

Tem alguma dificuldade com a língua? Grafia, regência, concordância...?

Não tenho especial dificuldade, mesmo porque me socorro sempre dos dicionários. Mas um deslize ou outro sempre aparece, quando da revisão de meus livros.

Suas músicas e livros não tomam liberdade com a língua oficial. A exceção talvez seja "quem te viu, quem te vê", pronome paulistês descontraído misturado com "quem não a conhece...", "quem jamais a esquece...". E depois, "Todo ano eu lhe fazia uma cabrocha de alta classe, de dourado lhe vestia...". "te" paulista e "lhe" carioca. Compôs assim só porque lhe pareceu a melhor forma?

Quando comecei a gravar minhas canções, em meados dos anos 60, era não só aceitável como, às vezes, bem-vindo o uso de coloquialismos, o desrespeito à norma culta. Havia uma idéia mais ou menos disseminada, talvez desde a época dos CPCs da UNE, de que as letras de música popular deviam se aproximar do linguajar comum.

Qual é o seu método de trabalho? É sistemático? Tem horários, disciplina? Trabalha todos os dias? Recolhe-se? Viaja para ter sossego?

Quando escrevo um livro, trabalho sem parar, até dormindo. Às vezes, viajo para ter sossego, às vezes, fico por aqui mesmo, mas mando dizer que estou na fazenda, embora não tenha fazenda.

Alguns autores começam a escrever e não sabem o que vai acontecer depois. Que a história se conduz sozinha. Era o que dizia Georges Simenon. Como é no seu caso?

Quando começo a escrever sei exatamente o que vai acontecer depois. Só que depois acontece outra coisa.

Rascunha, desenvolve a ideia primeiro na mente ou faz um esboço escrito? Ou escreve diretamente ao computador, sem escalas?

Escrevo rascunhos, esboços, ideias esparsas, no computador ou em qualquer papel ao alcance da mão. Quando o livro já está encaminhado, escrevo no computador, imprimo, leio, risco, rasuro, anoto, volto ao computador, imprimo, leio e assim sucessivamente. Reescrevo tudo inúmeras vezes.

Ernest Hemingway trabalhava de pé, diante da máquina de escrever posta numa plataforma alta. E você?

Escrevo sentado, mas as melhores ideias me vêm em movimento. Ando pela casa, saio andando pela rua com uma caneta e um bloco no bolso.

Demora muito para criar? Empaca às vezes? Trabalha sob pressão? Obriga-se a trabalhar? Você levava mais tempo antes do que agora para compor?

Tudo tem demorado mais, cada vez mais. Empaco muitas vezes, mas não me sinto pressionado, geralmente trabalho com prazer. Com a experiência, a gente aprende a fazer tudo mais devagar.

Como se sente quando termina um trabalho? Alívio, frustração, euforia, dor de barriga? 
Vazio.

Que influências literárias recebeu?

No começo eu queria ser Rubem Braga, escrevia crônicas nos jornais do colégio. Depois quis ser escritor russo. Depois virei escritor francês, fui virando Flaubert, Zola, Proust, acabei sendo Céline, eu adorava Louis Ferdinand Destouches, dito Céline. Na Faculdade de Arquitetura e Urbanismo, eu já estava para ser Kafka, quando um colega me disse para deixar de ser besta e me mandou ler em português. Foi mais ou menos nessa época que virei Guimarães Rosa. Depois virei músico e parei de ler. Também li muito Graciliano, Vinícius, Bandeira, João Cabral, muito João Cabral.

E na música? Quem você ouviu ou ouve mais?

Ouvi de tudo, desordenadamente, mas o que mais me impressionou, e para sempre, foi a primeira audição de Chega de Saudade, de Tom e Vinícius, com João Gilberto.

Você aprendeu outras línguas sempre nos países de origem ou estudou alguma no Brasil?

Italiano aprendi na Itália, onde morei dois anos quando menino. $\mathrm{Na}$ mesma época aprendi inglês, língua que se falava na escola americana de Roma. $\mathrm{O}$ francês elementar, que aprendi no ginásio em São Paulo, aprimorei com leituras, muitas leituras. $\mathrm{O}$ espanhol aprendi falando, chutando, confundindo com o italiano, em minhas viagens pela América Latina. Também leio bastante em espanhol. Tenho, aliás, facilidade para desaprender essas línguas, por isso me forço a ler o que posso no original. Em 64 ou 65, fui aluno ouvinte de Boris Schnaiderman [professor de Língua e Literatura Russa] na Faculdade de Filosofia, Ciências e Letras da USP. Eu tinha a pretensão de ler Tolstoi e Dostoievski em russo, mas não passei do alfabeto cirílico.

É muito diferente compor músicas e escrever romances ou peças?

Escrever romances é muito diferente de compor músicas. E minhas peças de teatro, peças musicais, têm mais afinidade com a música que com a literatura. A música acaba marcando a minha literatura. As personagens são obsessivas, repetem-se, são como personagens de música, são como temas de música, que tendem a repetir-se. Mas o princípio que me move é o mesmo: vontade de me comunicar.

Já abandonou projetos começados?

Bem, há projetos de canções que ficam pelo caminho, isso acontece o tempo inteiro. E agora me lembro de uma comédia teatral, O Dia em que Frank Sinatra Veio ao Brasil, projeto que abandonei com a morte de Paulo Pontes, então meu parceiro.

E já retomou alguns, depois de abandonados?

Tenho uma gaveta cheia de músicas abandonadas, mas não costumo abri-la. Eu teria dificuldade em mexer nessas músicas. Tenho a impressão de que elas endureceram, e aqui estou plagiando Ernst Jünger [romancista alemão, 1895-1998], quando se referia à sua incapacidade de mexer em seus antigos escritos.

A sensibilidade feminina expressa em algumas de suas músicas (em geral temas de personagens) é tão grande que chegaram a pensar que uma mulher as tivesse composto. Sua porção mulher é muito pronunciada?

Eu é uma moça. 
Você já quis botar letra em algumas músicas, mas desistiu. Lembro uma do Astor Piazzola. Isso acontece muito?

Tenho quatro gavetas cheias de músicas alheias que não consegui letras. Essas gavetas eu abro de vez em quando, e já me aconteceu de escrever a letra para uma música que me fora enviada 15 anos antes e ainda estava maleável. Se deixo de escrever letras e músicas é simplesmente porque não dou conta do serviço, sou um artífice vagaroso. Acho até que já escrevi músicas e letras em demasia, mas ainda assim vou ficar devendo.

Suas histórias em geral são "difíceis", de estrutura incomum. Você se preocupa em ser original, não-linear? Ou elas se compõem assim naturalmente para você?

Não, não me preocupo em ser original. Acho que sou meio esquisito mesmo.

Alguns estranham seu novo $\mathrm{CD}$ à primeira audição. A maioria das músicas não é assobiável. Pelo menos não à primeira, ou às primeiras audições.

Mais de uma pessoa já disse que não é fácil gostar desse disco na primeira audição. Talvez não seja mesmo. Nisso, lembra o anterior. Mas tenho a esperança de que ele seja ouvido outras vezes. No meu caso, é difícil esperar que uma de minhas canções seja um grande sucesso, que toque no rádio. Minhas músicas agora resultam de um tempo maior de meditação, de apuro. Todas são mais trabalhadas. E não só na composição, mas nos arranjos, no estúdio. É um trabalho mais sério, mais pensado. Ele e outros não saíram assim porque eu queria fazer música pretensiosa, refinada ou rebuscada de propósito. Acho que minhas músicas mais recentes são o resultado do amadurecimento. Talvez por isso quem sabe durem mais...

Por causa desse estranhamento, você acha que seu trabalho não é bem compreendido? Sei que em jornal, crítico de música geralmente é crítico de letra. É difícil não ser de outro jeito. A letra é visível, impressa, a partitura não. No entanto, eu dou cada vez mais importância à música. Quase sempre faço a letra que a música pede. Todos deviam perceber que as letras não são poesia; elas se integram à música para compor uma canção. Talvez seja pedir demais.

Na música Subúrbio, você chama a atenção para a periferia do Rio...

Sim, eu quis cantar a periferia. Tem relação com a posição marginal do Brasil no mundo e com a posição cada vez mais periférica do Rio em relação às tomadas de decisão do poder, quase sempre concentradas em São Paulo. O subúrbio que eu canto é a periferia fora do mapa de uma cidade, ela própria meio marginal. Mesmo assim, o subúrbio ainda mantém um lado idílico, com suas tradições e formas de expressão próprias. Foi isso que me motivou. Não a saudade do velho Rio e do velho subúrbio, que todo mundo tem. O que me inspirou foi o subúrbio de hoje.

Depois dos governos de FHC e de Lula, você ainda tem esperanças na política?

Os dois decepcionaram. A pessoa que chega ao poder se torna um pouco fantasma daquela que deu a vida por algo que não se realizou.

\section{Entrevista com Chico Buarque - Brazucaonline - abril/2010 - Por Daniel Cariello e Thiago Araújo}


Chico Buarque, na Brazuca: "Podendo, vou até os 95

"Se tiver bola, eu dou a entrevista". Essa foi a única exigência do nosso companheiro de pelada, Chico Buarque, numa caminhada entre o metrô e o campo. Uma bola. E eu acabara de informar que o dono da redonda não viria à pelada de quarta-feira. Éramos dez amantes do futebol, órfãos.

Sem saber se esse era um gol de letra dele para fugir da solicitação de seus parceiros jornalistas, ou uma última esperança, em forma de pressão, de não perder a religiosa partida, eu, que não creio, olhei para o céu e pedi a Deus: uma pelota!

Nada de enigma, oferenda ou golpe de Estado. Ele estava ali, o cálice sagrado da cultura brasileira, que sucumbiu ao ver não uma, mas duas bolas chegarem à quadra pelas mãos de Mauro Cardoso, mais conhecido como Ganso. A partir daí, nada mais alterou o meu ânimo e o da minha dupla de ataque-entrevista, Daniel Cariello. Apesar de termos jogado no time adversário do ilustre entrevistado, tomado duas goleadas consecutivas de $10 \times 6$ e $10 \times 1$, tínhamos a certeza de que ele não iria trair dois dos principais craques do Paristheama, e sua palavra seria honrada.

Mas o desafio maior não era convencer o camisa 10 do time bordeaux-mostarda parisiense a ceder duas horas de sua tarde ensolarada de sábado. O que você perguntaria ao artista ícone da resistência à ditadura, parceiro de Tom Jobim, Vinicius de Morais e Caetano Veloso, escritor dos best sellers "Estorvo", "Benjamin", "Budapeste" e "Leite Derramado", autor de "A banda", "Essa moça tá diferente", "O que será", "Construção" e da canção de amor mais triste jamais escrita, "Pedaço de mim"?

Admirado e amado por todas as idades, estudado por universitários, defendido por Chicólatras, oráculo no Facebook, onipresente nas manifestações artísticas brasileiras sua modéstia diria "isso é um exagero", mas sabemos que não é -, sua reação imediata ao ser comparado a Deus foi "em primeiro lugar, não acredito em Deus. Em segundo, não acredito em mim. Essa é a única coisa que pode nos ligar. Então, pra começo de conversa, vamos tirar Deus da mesa e seguir em frente".

Enfim, ainda não creio que entrevistamos Deus, quase sem falar de Deus. Mas foi com ele mesmo que aprendi uma lição, talvez um mandamento: acreditar em coisas inacreditáveis.

Você assume que não acredita em Deus, mas existem trechos nas suas músicas como "dias iguais, avareza de Deus" ou "eu, que não creio, peço a Deus". No Brasil, é complicado não acreditar em Deus?

Eu não tenho crença. Eu fui criado na Igreja Católica, fui educado em colégio de padre. Eu simplesmente perdi a fé. Mas não faço disso uma bandeira. Eu sou ateu como o meu tipo sanguíneo é esse. Hoje há uma volta de certos valores religiosos muito forte, acho que no mundo inteiro. $\mathrm{O}$ que é perigoso quando passa para posições integristas e dá lugar ao fanatismo. O Brasil talvez seja o pais mais católico do mundo, mas isso é um pouco de fachada. Conheço muitos católicos que vão à umbanda, fazem despacho. $\mathrm{E}$ fica essa coisa de Deus, que entra no vocabulário mais recente, que me incomoda um pouquinho. Essa coisa de "vai com Deus", "fica com Deus". Escuta, eu não posso ir com o diabo que me carregue? (Risos). Tem até um samba que fala algo como "é Deus pra lá, Deus pra cá - e canta - Deus já está de saco cheio" (risos).

Você já foi em umbanda, candomblé, algo do tipo? 
Já, eu sou muito curioso. A mulher jogou umas pipocas na minha cabeça, sangue, disse que eu estava cheio de encosto. Eu fui porque me falaram "vai lá que vai ser bom". Passei também por espíritas mais ortodoxos, do tipo que encarnava um médico que me receitou um remédio para o aparelho digestivo. Aí eu fui procurar o remédio e ele não existia mais. O remédio era do tempo do médico que ele encarnava (risos). Já tive também um bruxo de confiança, que fez coisas incríveis. Aquela música do Caetano dizia isso muito bem, "quem é ateu, e viu milagres como eu, sabe que os deuses sem Deus não cessam de brotar." Eu vi cirurgias com gilete suja, sem a menor assepsia, e a pessoa saía curada. Estava com o joelho ferrado e saía andando. Eu fui anestesista dessa cirurgia. A anestesia era a música. O próprio Tom Jobim tocava durante as cirurgias. Eu toquei para uma dançarina que estava com problema no joelho. Ela tinha uma estreia, mas o ortopedista disse "você rompeu o menisco". Ela estreou na semana seguinte, e na primeira fila estavam o ortopedista e o bruxo (risos). Uma vez, estava com um problema e fui ao médico. Ele me tocou e não viu nada. Aí eu disse "olha, meu bruxo, meu feiticeiro, quando ele apertava aqui, doía". Ele começou a dizer "mas essa coisa de feitiçaria..." e atrás dele tinha um crucifixo com o Cristo. Daí eu perguntei "como você duvida da feitiçaria, mas acredita na ressurreição de Cristo?". Eu acho isso uma incongruência. Gosto de acreditar um pouco nisso, um pouco naquilo, porque eu vejo coisas inacreditáveis. Eu não acredito em Deus, acredito que há coisas inacreditáveis.

De vez em quando você dá uma escapada do Brasil e vem a Paris. Isso te permite respirar?

Muito mais. Eu aqui não tenho preocupação nenhuma, tomo uma distância do Brasil que me faz bem. Fico menos envolvido com coisas pequenas que acabam tomando todo o meu tempo. Aqui, eu leio o Le Monde todos os dias, e fico sabendo de questões como o Cáucaso, os enclaves da antiga União Soviética, que no Brasil passam muito batidos. O Brasil, nesse sentido, é muito provinciano, eu acho que o noticiário é cada vez mais local. Meu pai, que era um crítico literário e jornalista, foi morar em Berlim no começo dos anos trinta. Foi lá, onde teve uma visão de historiador, de fora do país, que ele começou a escrever Raízes do Brasil, que se tornou um clássico. A possibilidade de ter esse trânsito, de ir e voltar, eu acho boa. É como você mudar de óculos, um para ver de longe e outro para ver de perto.

Nesse seu vai e vem Brasil-França, o que você traria do Brasil para a França, e viceversa?

Eu traria pra cá um pouquinho da bagunça, da desordem. Os nossos defeitos, que acabam sendo também nossas qualidades. $\mathrm{O}$ tratamento informal, que gera tanta sujeira, ao mesmo tempo é uma coisa bonita de se ver. Você tem uma camaradagem com um sujeito que você não conhece. Aqui existe uma distância, uma impessoalidade que me incomoda. Para o Brasil, eu gostaria de levar também um pouco dessa impessoalidade. Da seriedade, principalmente para as pessoas que tratam da coisa pública. Não que não exista corrupção na França. Outra coisa que eu levaria pra lá é o sentimento de solidariedade, que existe entre os brasileiros que moram fora. Isso eu conheci no tempo que eu morava fora, e vejo muito aqui através das pessoas com as quais convivo. Eles se juntam. Como se dizia, "o brasileiro só se junta na prisão". Os brasileiros também se juntam no exílio, na diáspora.

Falando em exílio, tem uma história curiosa de Essa moça tá diferente, a sua música mais conhecida na França. 
É. A coisa de trabalho (N.R.: na Itália, onde Chico estava em exílio político, em 1968) estava só piorando e o que me salvou foi uma gravadora, a Polygram, pois minha antiga se desinteressou. A Polygram me contratou e me deu um adiantamento. E consegui ficar na Itália um pouco melhor. Mas eu tinha que gravar o disco lá. Eu gravei tudo num gravador pequenininho. Um produtor pegou essas músicas e levou para o Brasil, onde o César Camargo Mariano escreveu os arranjos. Esses arranjos chegaram de volta na Itália e eu botei minha voz em cima, sem que falasse com o César Camargo. Falar por telefone era muito complicado e caro. Então foi feito assim o disco. É um disco complicado esse.

Você acabou de citar o Le Monde. Para nós, que trabalhamos com comunicação, sempre existiu uma crítica pesada contra os veículos de massa no Brasil. Você acha que existe um plano cruel para imbecilizar o brasileiro?

Não, não acredito em nenhuma teoria conspiratória e nem sou paranoico. Agora, aí é a questão do ovo e da galinha. Você não sabe exatamente. Os meios de comunicação vão dizer que a culpa é da população, que quer ver esses programas. Bom, a TV Globo está instalada no Brasil desde os anos 60. O fato de a Globo ser tão poderosa, isso sim eu acho nocivo. Não se trata de monopólio, não estou querendo que fechem a Globo. E a Globo levanta essa possibilidade comparando o governo Lula ao governo Chávez. Esse exagero.

O que você tem escutado?

Eu raramente paro para ouvir música. Já estou impregnado de tanta música que eu acho que não entra mais nada. Na verdade, quando estou doente eu ouço. Inclusive ouvi o disco do Terça Feira Trio, do Fernando do Cavaco, e gostei. Nunca tinha visto ou ouvido formação assim. Tem ao mesmo tempo muita delicadeza e senso de humor.

A música francesa te influenciou de alguma maneira?

Eu ouvi muito. Nos anos 50, quando comecei a ouvir muita música, as rádios tocavam de tudo. Muita música brasileira, americana, francesa, italiana, boleros latino americanos. Minha mãe tinha loucura por Edith Piaf e não sei dizer se Piaf me influenciou. Mas ouvi muito, como ouvi Aznavour. O que me tocou muito foi Jacques Brel. Eu tinha uma tia que morou a vida inteira em Paris. Ela me mandou um disquinho azul, um compacto duplo com $\mathrm{Ne}$ me quitte pas, La valse à mille temps, quatro canções. E eu ouvia aquilo adoidado. Foi pouco antes da bossa nova, que me conquistou para a música e me fez tocar violão. As letras dele ficaram marcadas para mim. Eu encontrei o Jacques Brel depois, no Brasil. Estava gravando Carolina e ele apareceu no estúdio, junto com meu editor. Eu fiquei meio besta, não acreditei que era ele. Aí eu fui falar pra ele essa história, que eu o conhecia desde aquele disco. Ele disse "é, faz muito tempo". Isso deve ter sido 1955 ou 56, esse disquinho dele. Eu o encontrei em 67. Depois, muito mais tarde, eu assisti a L'homme de la mancha, e um dia ele estava no café em frente ao teatro. Eu o vi sentado, olhei pra ele, ele olhou pra mim, mas fiquei sem saber se ele tinha olhado estranhamente ou se me reconheceu. Fiquei sem graça, pois não o queria chatear. Ele estava ali sozinho, não queria aborrecer. Mas ele foi uma figuraça. Eu gostava muito das canções dele. Conhecia todas.

Falando de encontros geniais, você tem uma foto com o Bob Marley. Como foi essa história? 
Foi futebol. Ele foi ao Brasil quando uma gravadora chamada Ariola se estabeleceu lá e contratou uma porção de artistas brasileiros, inclusive eu, e deram uma festa de fundação. O Bob Marley foi lá. Não me lembro se houve show, não me lembro de nada. Só lembro desse futebol. Eu já tinha um campinho e disseram "vamos fazer algo lá para a gravadora". Bater uma bola, fazer um churrasco, o Bob Marley queria jogar. E jogamos, armamos um time de brasileiros e ele com os músicos. Corriam à beça.

Vocês fumaram um baseado juntos?

Não. Dessa vez eu não fumei.

E essa sua migração para escritor, isso é encarado como um momento da sua vida, já era um objetivo?

Isso não é atual. De vinte anos pra cá eu escrevi quatro romances e não deixei de fazer música. Tenho conseguido alternar os dois fazeres, sem que um interfira no outro. Eu comecei a tentar escrever o meu primeiro livro porque vinha de um ano de seca. Eu não fazia música, tive a impressão que não iria mais fazer, então vamos tentar outra coisa. $\mathrm{E}$ foi bom, de alguma forma me alimentou. Eu terminei o livro e fiquei com vontade de voltar à música. Fiquei com tesão, e o disco seguinte era todo uma declaração de amor à música. Começava com Paratodos, que é uma homenagem à minha genealogia musical. E tinha aquele samba (cantarola) "pensou, que eu não vinha mais, pensou". Eu voltei pra música, era uma alegria. Agora que terminei de escrever um livro já faz um ano, minha vontade é de escrever música. Demora, é complicado. Porque você não sai de um e vai direto para outro. Você meio que esquece, tem um tempo de aprendizado e um tempo de desaprendizado, para a música não ficar contaminada pela literatura. Então eu reaprendo a tocar violão, praticamente. Eu fiquei um tempão sem tocar, mas isso é bom. Quando vem, vem fresco. É uma continuação do que estava fazendo antes. Isso é bom para as duas coisas. Para a literatura e para a música.

Tanto em Estorvo quanto em Leite derramado o leitor tem uma certa dificuldade em separar o real do imaginário. Você, como seus personagens, derrapa entre essas duas realidades?

Eu? O tempo todo, agora mesmo eu não sei se você está aí ou se eu estou te imaginando (gargalhadas). Completamente. Eu fico vivendo aquele personagem o tempo todo. Entrando no pensamento dele. Adquiro coisas dele. Você pode discordar, mas chega uma hora que tem que criar uma empatia ou uma simpatia. Você cria uma identificação. E alguma coisa no gene é roubado mesmo de mim, algumas situações, um certo desconforto, não saber bem se você é real, se você está vivendo ou sonhando aquilo. Por exemplo, agora que ganhamos de 10 a 1 (referência à pelada que jogamos três dias antes), eu saí da quadra e falei: "acho que eu sonhei. Não é possível que tenha acontecido" (risos).

Você é fanático por futebol?

Não sou fanático por nada. Mas eu tenho muito prazer em jogar futebol. Em assistir ao bom futebol, independentemente de ser o meu time. Quando é o meu time jogando bem, é melhor ainda, pois eu consigo torcer. Agora mesmo, no Brasil, tinha os jogos do Santos. Mas eu vou menos aos estádios. Eu não me incomodo de andar na rua, mas quando você vai a alguns lugares, tem que estar com o cabelo penteado, tem que estar preparado para dar entrevistas. Aqui, eu estou dando a minha última (risos). Aqui, é 
exclusiva. Fiz pra Brazuca e mais ninguém. Eu quero ver o pessoal jogar bola. Então eu vejo na televisão. E quando não estou escrevendo, aí eu vejo bastante.

É verdade que um dia o Pelé ligou na sua casa, lamentando os escândalos políticos no Brasil, e disse "é, Chico, como diz aquela música sua: 'se gritar pega ladrão, não fica um meu irmão""?

É verdade (risos). Eu falei "legal, Pelé, mas essa música não é minha”. O Pelé é uma grande figura. Nós gravamos um programa juntos. Brincamos muito. Conheci o Pelé quando eu fazia televisão em São Paulo, na TV Record, e me mudei para o Rio. Os artistas eram hospedados no Hotel Danúbio, em São Paulo. O mesmo onde o Santos se concentrava. Então, eu conheci o Pelé no hotel. E sempre que a gente se encontra é igual, porque eu só quero falar de futebol e ele só quer saber de música. Ele adora fazer música, adora cantar, adora compor. Por ele, o Pelé seria compositor.

E você, trocaria o seu passado de compositor por um de jogador?

Trocaria, mas por um bom jogador, que pudesse participar da Copa do Mundo. Um pacote completo. Um jogador mais ou menos, aí não.

Você ainda pretende pendurar as chuteiras aos 78 anos, como afirmou?

Não. Já prorroguei. Tava muito cedo. Agora, eu deixei em aberto. Podendo, vou até os 95 (risos).

O Niemeyer está com 102 anos e continua trabalhando. Aliás, não só trabalhando como ainda continua com uma grande fama de tarado (risos).

Ele me falou isso. Eu fui à festa dele de 90 anos e ele me disse: "o importante é trabalhar e ó (fez sinal com a mão, referente a transar)". Aí eu falei "é mesmo?" e ele respondeu "é mesmo".

Falando nisso, o Vinícius foi casado nove vezes. Você acha a paixão essencial para a criação?

Sem dúvida. Quando a gente começa - isso é um caso pessoal, não dá pra generalizar faz música um pouco para arranjar mulher. E hoje em dia você inventa amor para fazer música. Se não tiver uma paixão, você inventa uma, para a partir daí ficar eufórico, ou sofrer. Aí o Vinícius disse muito bem, né? "É melhor ser alegre que ser triste... mas pra fazer um samba com beleza, é preciso um bocado de tristeza, é preciso um bocado de tristeza, senão não se faz um samba não". Quando eu falo que você inventa amores, você também sofre por eles. "E a moça da farmácia? Ela foi embora! Elle est partie en vacances, monsieur!". E você não vai vê-la nunca mais. Dá uma solidão. Eu estou fazendo uma caricatura, mas essas coisas acontecem. Você se encanta com uma pessoa que você viu na televisão, daí você cria uma história e você sofre. E fica feliz e escreve músicas.

Pra finalizar. Se você fosse escrever uma carta para o seu caro amigo hoje, o que você diria?

Volta, que as coisas estão melhorando!

\section{Entrevista com Chico Buarque - Revista Rolling Stones - outubro/2011}

"Eu teria de mudar a minha vida inteira." Chico Buarque está com o olhar perdido em direção ao chão da sala de sua cobertura, no Alto Leblon, no Rio de Janeiro. Ele não se 
refere a música ou política, mas a um terceiro elemento sempre associado à sua imagem pública: o futebol. Aos 67 anos, ele sente dores nas costas; em uma consulta, recebeu a notícia de que não poderia mais jogar nas partidas de seu time, o Polytheama. "Mas consultei outro médico e ele me disse que exatamente porque faço esse exercício eu não precisaria parar", diz.

As declarações deixam óbvia a importância do futebol na vida do artista, mas também puxam o ambiente para um universo além-arte. Nesta tarde de agosto, ele está disposto a falar sobre qualquer tema, sem limitação de tempo - uma oportunidade rara com um astro notoriamente avesso a ações promocionais. Atualmente, as chances de se cruzar com Chico em eventos sociais estão entre a de ser atingido por um raio e a de não encontrar um ex-BBB em uma festa open bar.

O apartamento é espaçoso, decorado discretamente. Em uma sala, um piano e um violão se encontram ao lado de um computador Macintosh. São instrumentos da alternância que ele mantém desde os anos 90, revezando o trabalho entre a literatura e a música. Agora, ele é o Chico Buarque compositor, que lançou Chico (o primeiro disco de estúdio desde 2006) e está imerso no processo da nova turnê (que deve começar em Belo Horizonte em novembro e passará pelas principais capitais).

Entre sorrisos e gargalhadas - ao perceber um assunto familiar, um meio sorriso surge; ao se empolgar com uma resposta, gargalha até perder o fôlego -, o músico revela à Rolling Stone Brasil um retrato preciso de como se encontra em 2011: calmo (mas não conformado), incisivo (e às vezes inseguro), mas jamais lacônico ou desinteressante. Após cinco décadas de atividade artística, Chico Buarque de Hollanda está pronto para mostrar seu lado humano sem hesitação ao caminhar pelo espaço reservado somente às lendas.

Você é conhecido por ser metódico no trabalho. E na vida cotidiana, também? Você se permite decisões espontâneas ou mantém o controle?

Eu não sabia que tinha fama de metódico. Na verdade, minha vida e meu trabalho se confundem, nem eu mesmo sei direito quando estou trabalhando ou não. Às vezes digo que estou muito atarefado, porque as pessoas pensam que um artista está sempre disponível para ir à festa. Como o artista em geral não tem horário, não dá expediente, costumam pensar que é vagabundo. Mas, assim como a criança se concentra num brinquedo, tem dias em que preciso me concentrar no trabalho, nem que seja compor um palíndromo ou inventar times de futebol.

Quando se propõe a fazer um disco, o processo de compor só começa quando você determina?

Não é nem um pouco regrado. O que acontece é que, hoje, compor se tornou um ato tão rarefeito que a cada vez que faço uma música me lembro exatamente - eu sei a história de cada composição, porque é um momento especial. É normal para qualquer compositor, qualquer criador, perder aquele entusiasmo juvenil com o [passar do] tempo, aquela exuberância criadora toda. Vai se tornando um criador mais seletivo. A imagem romântica do artista tem mais a ver com inspiração: você está na padaria, baixa a inspiração e escreve a letra. As pessoas não pensam que fazer música é um esforço consciente.

É e não é. Tem algo de mágico, algo que corresponde a essa ideia romântica. Porque você não faz a música quando quer, você não escreve e tem uma boa ideia quando quer. Agora, você tem que estar disponível para as ideias surgirem. A centelha que desencadeia a música continua tendo um certo mistério. A partir daí, o trabalho é 
trabalho. Você tem uma técnica, tem uma experiência. Dificilmente você vai escrever na padaria, mas pode, por exemplo, fazer isso caminhando. Muitas das minhas caminhadas são de trabalho. Vou caminhando e pensando em como desenvolver melhor uma música. Mas criar... eu preciso de um instrumento para criar, eu preciso do violão. Agora, a letra: posso andar com uma maquininha dessas, um fone de ouvido, ouvindo aquela música e desenvolvendo numa caminhada ou até mesmo na padaria. Estou o tempo todo a serviço dessa música. Se estiver num restaurante conversando, posso ter uma ideia que vai me tirar daquela conversa e me levar de volta para a minha música. É um pouco as duas coisas.

Em seu período de dedicação à literatura, a música - não como ofício - continua presente? Por exemplo, ouvindo música dos outros?

Não, não. Eu não ouço música. Na verdade, ouço pouca música. Escrevendo ou não escrevendo, ouço pouca música. Recebo um disco de um autor ou de uma cantora que me interessam, coisas que me recomendam. E é assim: ponho o $\mathrm{CD}$ no carro, que é o lugar onde mais ouço, e escuto aquilo. Quando você está escrevendo, criando, parece que é um choque! As coisas que entram, batem e saem. Quando estou escrevendo um livro, não tenho o menor interesse por música, fico inteiramente fora. Períodos como este agora: aí, sim, estou aberto a tudo e ouço coisas que aparecem.

A partir dos anos 00, sempre que vai explicar um novo disco, você diz: "Eu andava meio parado com a música”. Você já se considerou inseguro em relação a isso? Parece que existe um esforço consciente seu.

Sim, porque sair da inércia é complicado, tanto para a música quanto para a literatura. Quando eu me disponho a entrar na fase musical, requer um esforço. Não é do nada que aparece, não é assim. Tem que buscar. Minha primeira sensação, quando pego o violão depois de um longo tempo, é a de que não sei mais como se faz uma música. Eu não tenho ideia de como se compõe. É como se fosse um instrumento alheio, como se não me dissesse respeito. É um momento de quase flerte com a música, de procurar me reaproximar. Então pego o violão e começo a tocar: "Que diabo é isso? Pra onde vou?" Ou então os acordes já vêm na sequência que vinham antes, começam a se repetir e tocar quase que mecanicamente. Até voltar a dominar aquilo leva um bom tempo. Quando vou escrever um livro, é a mesma coisa. É um exercício, que se tem que fazer até se sentir dentro da coisa.

A expectativa a respeito de suas músicas é sempre alta. Essa pressão chega até você? Eu não posso me deixar levar por isso. E não adianta você querer matar um leão por dia, porque as pessoas sempre vão dizer que o leão antigo era melhor e mais forte do que o de hoje [risos]. Mas não é isso que vai me estimular. Existe uma pressão interna, sim, uma necessidade e um prazer grande em fazer uma música. Essa possibilidade de alternância é saudável, porque ninguém está esperando um disco novo meu daqui a um ano: nem eu, nem ninguém. Tem esse tempo todo agora, lento e de maturação. Escrever um livro provavelmente - e isso não precisa ser tão mecânico - vai tomar um longo tempo. Então, não acho que a gente deva se levar por esse tipo de pressão. Não tenho contrato com gravadora, não tenho obrigação nenhuma e já é suficiente a pressão que a gente exerce sobre si próprio.

Hoje se vendem menos discos. Faz diferença?

Não, para mim não faz. Tanto é que eu fiquei sabendo mais ou menos dessas novidades durante as conversas de lançamento do disco. Então me foi apresentado um projeto de lançar o disco pela internet e eu não conhecia nada disso. E aí eu fui conhecer a realidade do mercado. Eu andava longe disso havia cinco ou seis anos e não sabia que tinha mudado tanto assim. A previsão do lançamento de um disco é, em termos 
numéricos, muito inferior agora. Então, tentei compensar a gravadora, de certa forma, pelo investimento que ela fez, colaborando no projeto de lançamento deles. Internet e aquela coisa do site e tal. Mas isso não é assunto meu. Eu, na verdade, cheguei a uma altura da vida que não preciso mais do disco para sobreviver. Eu já tenho basicamente aquilo que eu preciso, não tenho grandes ambições. Já tenho certa estabilidade financeira e não preciso ficar muito preocupado com isso. Meus discos vendem direitinho, tenho direitos autorais aqui e lá fora. Os livros vendem mais do que os discos, inclusive [risos]. E os livros são vendidos lá fora. Não tenho essa preocupação.

Como estão os planos para a turnê?

Quem está vendo isso é o pessoal da produção, porque fazer um show hoje em dia... Para me sentir confortável no palco, vou querer chamar meus músicos, meus amigos com quem eu já me dou bem. As músicas são novas, os amigos não precisam ser novos, são os velhos mesmo. Para montar isso tudo é uma estrutura grande. Precisa de patrocínio. Vou precisar de um mês, talvez mais, para ensaiar. Para pagar isso, tem de fazer praticamente uma temporada de pelo menos um ano para viabilizar. O pessoal que mexe com isso está procurando uma maneira de viabilizar economicamente esse show. Isso passa por patrocínio e, evidentemente, um patrocínio de um show meu não pode contar com isenção fiscal, com Lei Rouanet, com nada disso. Senão, seria mais fácil [risos]. Mas mesmo no meu último show eu não tinha isso.

Por opção? Porque você prefere?

Hoje eu nem poderia porque acontece, por acaso, que a minha irmã é a ministra da Cultura. Mas o último show já era, se não me engano, o governo Lula. Gil era o ministro da Cultura e achei melhor não entrar com patrocínio via Lei Rouanet. Mas isso dificulta. Você sabe disso, né? Não é qualquer empresa que vai querer simplesmente associar o nome a um artista sem poder abater no seu imposto de renda e tal.

A Lei Rouanet é uma questão peculiar para artistas do seu tamanho. As pessoas parecem não entender direito como ela funciona.

Parece que não há muita boa vontade em deixar claro, para o grande público, o que é a Lei Rouanet. Sempre se passa essa ideia de que o governo está bancando um artista, de que o Ministério da Cultura está financiando um filme, uma peça, um show de artista famoso. O Ministério, pelo contrário, patrocina justamente quem não tem acesso à Lei Rouanet. Ela permite que o artista busque patrocínio na iniciativa privada, mediante isenção fiscal. Não cabe ao Ministério julgar se o artista precisa ou não de alguma ajuda pessoal, cabe a ele julgar o mérito do projeto apresentado. Há quem seja contra porque acredita que o Estado não deve dar incentivo algum às artes e à cultura. É um ponto de vista. Eu nem queria entrar muito nesse assunto. Estou entrando assim, de raspão, porque desde que minha irmã foi nomeada ministra eu me sinto impedido de opinar. Até fico fora do assunto de direito autoral para não parecer que eu tenho alguma coisa a ver com isso. Para mim é um incômodo ter uma irmã no Ministério da Cultura.

A Ana de Hollanda foi criticada por ter uma postura em relação aos direitos autorais que foi considerada um retrocesso em relação aos ministros anteriores. Você tem opinião sobre isso?

Não tenho e me mantive alheio a esse assunto. Exatamente porque desde o início tentou-se passar a impressão de que eu teria alguma ingerência na nomeação da minha irmã como ministra. Para mim, o mais confortável era que o Juca Ferreira continuasse sendo ministro. Até mesmo para que as pessoas xingassem o Juca Ferreira e não a minha irmã nos jornais [risos]. Quando entra esse assunto de direitos autorais, volta e meia sou procurado, recebo e-mails e tal. Digo: "Prefiro não me interessar por isso". São tantos assuntos pelos quais a gente tem de se interessar, tantos jornais que a gente 
tem de ler, tantas notícias que a gente tem que ficar por dentro, que eu prefiro deixar esse de lado. E há colegas meus que estão brigando, discutindo isso com muito mais conhecimento de causa do que eu. Prefiro não opinar. Nem sei direito o que é o Creative Commons, o que isso deixa de ser. Eu sei que o selo foi tirado do [site do] Ministério. O que isso representa, eu não sei.

Quem participar de um jantar no qual estivessem você e a Ana ouvirá que tipo de conversa?

Ouvirá muita conversa jogada fora. Somos muitos irmãos, todos nos damos bem, mas quando nos encontramos ninguém se mete na vida do outro. Só pelas costas.

Você acha que esperam que você tenha opinião sobre política porque no passado você foi tão ligado a esse tema?

Acho que nem se espera mais tanto. Isso acontece durante as campanhas eleitorais quando fica impossível, para mim, não tomar partido. Porque eu acompanho a política do país desde garoto, desde os tempos do Juscelino [Kubitschek]. A primeira vez que votei foi pela volta do presidencialismo, João Goulart, e desde então me interesso por política e me manifesto. Agora, a vida política, o dia a dia, não me atrai nem um pouco e nem faço questão de ficar me manifestando. Durante uma campanha eleitoral, o artista é praticamente compelido a se manifestar. Porque senão vão dizer: "Cadê os artistas que estavam falando e agora não falam mais nada, estão em cima do muro?" Eu sei perfeitamente o que faço quando tomo partido durante uma campanha. Na última, apoiei a Dilma e sabia que isso ia atrair o ódio de quem votou no Serra. Se eu apoiasse o Serra, provavelmente ia atrair o ódio de quem votou na Dilma. Nesse momento, tudo fica exacerbado. Mas não vou ficar me pautando por isso, pelo medo de ser odiado por essa ou por aquela parcela da opinião pública. Isso passa com o tempo. Quer dizer, passa em termos. Porque há sempre uma cobrança. "Você apoiou, o que você acha disso e daquilo?" Eu apoiei e não me arrependo. É mais cômodo ser oposição, sem dúvida. Eu votei no Jango, na volta do Jango à presidência da República depois da tentativa de golpe de 1961, que não durou muito, pois em 1964 veio o golpe militar. O que eu apoiava no Jango é o que o governo Lula mais ou menos implantou no país. O que me envergonhava nos anos 60 era o que me envergonhava até há pouco. O Brasil era um país tão rico, eu vivia num país tão rico e tão desigual. Essa desigualdade, de certa forma, foi reduzida. Ou se tentou reduzir, investiu-se nisso, na redução da miséria por meio de programas sociais. E também me envergonhava viver num país internacionalmente insignificante, subserviente. Acredito que durante o governo Lula se criou uma política externa mais condizente com a importância do país. O país cresceu aos olhos do mundo devido a essa política externa.

Nos anos 90, muita música brasileira foi redescoberta lá fora. Os Mutantes, pela identificação com a psicodelia; o Tom Zé foi descoberto pelo David Byrne. Só que você não passou por isso.

Não passei. Mas outro dia fui jogar futebol em Lisboa e o Felipão [Luiz Felipe Scolari] era o técnico. Era um jogo dos amigos do Zidane contra os amigos do Figo. Ele me escalou de saída, e o baterista do Radiohead [Phil Selway] ficou lá no banco, emburrado, porque ele não saiu jogando e eu sim. No intervalo, falei pra ele: "Escuta, não fica aí de cara feia porque o nome da sua banda é roubado de uma música minha" [risos]. O David Byrne ouviu a "rádio cabeça" [a música "O Último Blues", que contém o verso "na Rádio Cabeça"], quando foi lançado o disco da Ópera do Malandro. Ele esteve aqui e cantou "A Volta do Malandro" no Canecão. Ele deve ter achado que era uma expressão que se usava muito no Brasil e fez a música lá dele ["Radio Head", de True Stories, 1986] que deu origem ao [nome do] Radiohead. Então 
me sinto representado pelo Radiohead, por intermédio do David Byrne. Afora isso, já tentei fazer carreira lá fora quando morei na Itália e não fui bem-sucedido. Não tenho essa ambição. Mal faço shows aqui no Brasil, tenho preguiça de fazer shows lá fora e não passa pela minha cabeça a ambição de ser conhecido lá. Se alguém resolver - além do Radiohead - me fazer uma homenagem, está liberado! Pode fazer à vontade [risos]. Não me chateia não ter sido descoberto até agora.

\section{Você já disse que tirou músicas dos shows porque as acha datadas. O que data uma} música sua?

Posso atribuir essa datação às músicas mais agudas do tempo da ditadura. Algumas músicas que foram criadas meio que como uma função extramusical. Ou seja, com a intenção de desafiar o regime, a censura etc. Vamos dizer: músicas sinceras. Essas vivem menos, talvez seja isso. Outras ficam datadas musicalmente, porque são canções, harmonias que não representam mais o que me interessa hoje como uma solução harmônica, construção melódica. Essas têm remédio porque eu posso refazer, rearranjar, re-harmonizar. Agora, a meia dúzia de canções - "Apesar de Você", "Cálice", "Deus lhe Pague" - essas, para mim, ficaram datadas. Elas correspondem ao momento político e não fazem grande sentido hoje.

Será que essas músicas não têm um significado mais abrangente para o público? Pode ser, pode ser. Porque as pessoas têm uma lembrança afetiva da música. Elas gostam de determinadas músicas porque elas remetem a uma época feliz da sua vida. "Essa é a música que ouvi quando conheci a minha namorada." Isso existe independentemente do que diz a letra. Quando eu digo que não tenho vontade de cantálas porque elas são datadas, isso é pra mim! Eu não tenho vontade de cantar. Acredito que as pessoas que não tinham posições políticas claras na época possam ouvir "Apesar de Você" hoje e encontrar um valor afetivo muito grande, independentemente do que a letra diz. Isso até contraria um pouquinho o que você falou, porque as pessoas se deixam levar pela música e, às vezes, cantam a letra sem prestar atenção no que estão dizendo. Isso existe, basta lembrar as músicas que você cantava na infância. "Que engraçado, essa música quer dizer isso!" Você não entendia o que era e repetia. Ou as pessoas que cantam em inglês e muitas vezes não sabem o que diz aquilo. Elas gostam do som e aprendem a dizer aquelas palavras, não têm muita noção do que elas dizem. Ouvem músicas que fazem um enorme sucesso no mundo inteiro e que, na verdade, são compreendidas por uma parcela bem menor de pessoas.

Quem cumpre o papel de crítica social hoje?

Todo o rap que se faz aqui no Rio e em São Paulo é fortemente de crítica social. Eles fazem isso muito bem, com propriedade, falando dos problemas locais da comunidade. Falam muito de uma maneira que eu não saberia abordar. Nem me cabe, me sinto até excluído desse mundo. É direto, não há metáforas, não há censura. Vão direto ao ponto. Eu me sinto até um pouco intruso nesse meio. Para mim, o que acontece é que muitas vezes as pessoas falam: "Vem cá, porque você não fala [de problemas político-sociais nas letras]?" Eu me lembro quando estourou aquela história do Mensalão e, numa entrevista coletiva, perguntaram por que eu não falava daquilo. "Você quer que eu faça o quê? O 'Sambão do Mensalão'?" Não vou fazer o "Sambão do Mensalão", mesmo porque as pessoas se esquecem de que essas músicas todas que eu citei antes eram coisas que eu dizia e que, na época, os jornais não falavam. Não me interessa hoje repetir em música o que está todos os dias nos jornais. Nem me interessa muito dar entrevista falando mal do governo. Eu gostava de falar mal do governo quando os jornais não o faziam. 
O amor está presente no novo disco. Mas teve uma frase, de "Querido Diário", que foi muito comentada: "amar uma mulher sem orifício". Teve muito debate, a crítica a usou contra você.

No "Querido Diário" está lá: um dia, segundo dia, terceiro dia, quarto dia. Evidentemente que há algo de nonsense no sujeito que resolve, num belo dia, ter uma religião e, andando na rua, imagina que vai sacrificar uma ovelha. Já entrou nesse campo [risos]. Aí ele resolve ter uma adoração por uma estátua, ou seja, amar uma mulher sem orifício. Eu li em algum lugar que "amar uma mulher sem orifício" seria amar uma mulher casta, uma mulher difícil. Aí, se não é burrice, já é vontade de encher um pouquinho o saco do compositor.

Até os anos 80 a pergunta clichê que se fazia aos artistas era: "E a crítica?" Agora, virou: "E os paparazzi?". Você sente saudade de quando a crítica era o principal problema do artista?

$\mathrm{Ah}$, sim. Eu não estou entendendo o [que você quis dizer com] "o problema com a crítica". O problema com a crítica eu sempre tive...

É que hoje parece que há mais interesse sobre a vida pessoal do artista. Você percebe isso?

[Longo silêncio] Que a vida pessoal ficou muito mais exposta do que há 20, 30 anos, não tem a menor dúvida. Eu tenho de mudar algumas atitudes porque você está mais exposto do que antes, mas não me afeta tanto assim. Me afeta ao, por exemplo, ir à praia. Sempre, desde criança, gostei de ir à praia. Nasci em frente ao mar, nadava em Copacabana, pegava jacaré no Arpoador, mergulhava. Até três anos atrás eu ia à praia. Até o dia em que saio da praia e um sujeito se agarra em mim, começa a berrar, gritar no meu ouvido e a perguntar algumas coisas. Quando me dou conta: "Ih, tem um cara lá filmando. Isso aqui é um número cômico de um programa de televisão" [risos]. Eu agora faço parte de um programa de televisão e vou ter que lidar com isso. Não vou fazer uma cena, só fico pensando em quando é que vai acabar a história. Resultado: não posso ir à praia. Mas não é o fim do mundo. Deixo de ir à praia, deixo de ir ao restaurante da rua Dias Ferreira e pronto. Isso não me afeta grandemente. Falei sobre isso na internet: você está mais exposto, mas aí é você - pessoa - e sua obra também. Com a internet aumentou muito o número de críticos, se multiplicou um milhão de vezes. Como no caso dessa história do verso que você está apontando. Sei exatamente como ela foi criada: num blog de um cara da revista Veja, que tem uma enorme estima pela minha pessoa e gosta de lançar esse tipo de futrica. Ali vale tudo, já sugeriram até que se desapropriasse meu campo de futebol para a construção de casas populares. É um problema que vem de muitos anos, uma questão doentia de uma revista contra um artista. Parece que o cara que manda nessa revista tem ambições literárias. Então ele não gostou de os meus livros ganharem prêmios, porque ele quer ser escritor. Aí, decidi me vingar. Sabe o que eu fiz? Li o romance do cara, um tal de [Mario] Sabino. Não é parente do Fernando Sabino, acho. Fui até o fim, li tudo, tudo. E fiquei tranquilo, passou a raiva [risos]. Falei: "Bom, o melhor que esse cara tem a fazer é ser editor da revista Veja".

Questão inevitável: é ou já foi difícil ser o Chico?

É difícil ser o Chico quando as pessoas pensam que você é o Chico. Quando você entra no teatro e acham que você é o Chico e que você tem de falar sobre a sua vida ou sobre a sua obra e tal. Porque você está distraído. Você não anda na rua e pensa: "Ah, sou o Chico Buarque". Não passa pela cabeça do artista. A não ser que ele seja um louco e saia por aí, "Sou o Picasso, sou o Picasso". Não faz parte das minhas preocupações isso de "o que vou dizer" e "o que vou fazer". É difícil, às vezes, dar entrevista e ter de ficar 
se explicando. Fora isso, não tenho queixas, gosto de fazer o que faço. Não que seja fácil escrever livros e canções, mas é preciso sempre desconfiar das coisas fáceis.

Talvez para o artista não exista isso de ser artista o tempo todo, mas para as pessoas é um choque a diferença entre a expectativa e a realidade. Talvez tenha a decepção de...

[Interrompe] O tempo todo.

Os fãs te pedem conselhos na rua, esperando que você mude a vida deles? Pode acontecer. Se eu ficar parado num lugar, pode acontecer. Por isso estou sempre andando... [risos] Evito que as pessoas venham pedir conselho ou opinião. Mas geralmente o que pedem mais é autógrafo. Agora, mais que autógrafo, são as fotos. Fora isso, eu não fico parado.

O que faz quando quer flanar, conversar com pessoas anonimamente? Para onde você "foge"?

Ando todo dia nas ruas do Rio e quase nunca sou parado, me cumprimentam de passagem. Mas gosto de conversar com o jornaleiro, com as moças do café, com os caras da farmácia. No estrangeiro, além de andar pelas cidades, converso com gente que não faz ideia do que sou ou faço, e isso é bom. Uma ou duas vezes por ano passo uns dias em Paris, e mesmo ser maltratado de vez em quando - ser barrado em restaurante, empurrado no metrô, ouvir desaforo do chofer de táxi - é uma experiência educativa para famosos em geral.

Há uma impressão de que você é mais fechado - não em um nível João Gilberto -, mas certamente mais discreto do que Gil e Caetano. É consciente ou você se força para manter a discrição?

Olha, eu não me forço para nada. Sou o que sou, e se tem uma coisa que me chateia é gente que faz tipo.

A sua turma nos anos 70 era famosa por freqüentar bares para conversar. E hoje você tem essa necessidade de se reunir pessoalmente e trocar ideias com pessoas "equivalentes" a você, intelectuais, artistas, pensadores?

Gosto muito de conversar com meus amigos, que não são necessariamente intelectuais, artistas ou pensadores. Falamos de futebol, cinema, literatura e de otras cositas más. Política também discutimos, numa boa, ninguém nunca brigou com ninguém por causa de política ou de futebol. Em suma, gosto mesmo é de papo-furado em mesa de botequim. Se o pensador quiser me mostrar seus pensamentos, prefiro que o faça por escrito.

Você disse que escuta música com Francisco, seu neto de 14 anos. Como é a relação? Você se envolve com a educação dos netos ou debate com suas filhas a maneira de criá-los?

Imagina se as minhas filhas permitiriam que eu me envolvesse na educação das crianças. Fora que as meninas menores talvez nem saibam que sou seu avô. Eu sou o "Voíco", aquele cara que acha graça nelas. Já com o Francisco, aliás Chiquinho Brown, tenho algum diálogo musical. Outro dia vi um número dele no YouTube, um solo de guitarra numa banda cover do Iron Maiden. O Chiquinho é muito mais músico que eu, e estou falando sério. Estudou guitarra e violão, é exímio guitarrista, contrabaixista também, toca piano de ouvido, tem ouvido absoluto. Em breve vai se apresentar com sua nova banda, ainda sem nome, mas nem a mãe dele pode assistir. Parece que o show é num local proibido para maiores de dezoito anos. Da família só quem vai sou eu, como vocalista convidado. Devemos tocar "Jorge Maravilha", aquela do "você não gosta de mim, mas sua filha gosta". 
Você mora sozinho. Como foi essa transição, após tantos anos casado e com filhos em casa?

Já nasci cercado de muita gente, família grande. Casei moço, tive três filhas, e logo elas foram enchendo a casa com um monte de amigas e namorados. Era uma grande animação. Por isso, quando fui morar sozinho, pensei que fosse estranhar. Mas também é bom, é como um silêncio depois de muita música.

No vídeo sobre a internet postado no site do seu disco, você fala que um cara diz: “Olha o que a bebida faz com a pessoa". E aí você menciona que nem bebe mais. De onde veio essa decisão?

Parece mentira, né? [risos] Parei de tomar destilados há muito tempo. Mas já falei sobre isso. Falei até que tinha um bruxo que me deu umas ervas e enjoei de uísque. Minha bebida era o uísque - e nem vodca mais eu conseguia tomar. Fiquei tomando vinho, mas isso tem 20 anos.

Há uma associação forte da sua imagem nos anos 70, pré-politicamente correto, de entrevistas para a TV com um uísque na mão.

Com um copo e com um cigarro, um em cada mão.

Por isso você brincou: "Parece mentira". Talvez venha daí essa desconfiança.

É, não havia essa preocupação. Realmente, eu não vou falar de mim, mas agora tem muito essa história. Por exemplo, a Amy Winehouse. Aparece na Veja: "A cantora drogada Amy Winehouse vai gravar um disco..." Virou uma coisa absurda. A foto do Vinicius [de Moraes] na Livraria da Travessa: adulteraram. Tiraram não lembro se foi o copo ou o cigarro, acho que foi o copo. E ficou aquela mão-boba, sem o copo. Fizeram um Photoshop para não dar mau exemplo. E a gente bebia e fumava em cena, fazia parte da mise-en-scène: Vinicius sentado com aquela garrafa. Era normal, a gente ficava meio altinho. Hoje, puta que pariu... [risos] Se tivesse paparazzi naquela época... Além de paparazzi de foto, agora também tem ouvido paparazzo. Você está sentado num restaurante e tem o cara ali ao lado, o paparazzo orelhudo. No dia seguinte está na rede: "Fulano falou isso e aquilo". E os jogadores de futebol não podem tomar saquê porque vai a imprensa lá: "O jogador tomou 20 saquês". Isso acho chato, essa fiscalização moralista da vida dos outros. Bom, vou deixar de ir à praia, mas outras coisas não vou deixar de fazer. O meu vinho vou tomar, o meu cigarro vou fumar. Também fumo pouco, mas fumo - e não vou deixar de tomar o meu vinho e fumar porque tem um cara que vai dizer que você se embebeda e está destroçando os seus pulmões e tal, que você vai morrer e é benfeito.

Há um debate quanto ao surgimento de radicais, o que faz parte de se viver em uma democracia. Uma polêmica recente foi sobre o "Dia do Orgulho Hétero". Como manter o debate saudável? Radicais surgem de todos os lados...? Já surgiram. Na verdade, um projeto como esse que foi votado pela Câmara Municipal de São Paulo é a serviço e a reboque dessas manifestações que tem a toda hora: dos skinheads, que justificam bater em gays ou em supostos gays - um pai abraçando um filho toma porrada. Eles têm liberdade de se manifestar e vão se manifestar no Dia do Orgulho Hétero, que a Câmara fez o favor de criar. Não há o que fazer, numa democracia não se pode impedir nada. Nem que o norueguês junte os seus armamentos e saia matando. Não se pode proibir a veiculação de ideias, nem aquelas nas quais ele se baseou.

É um debate amplo. Vão continuar a questionar se a internet não deveria ser controlada.

Eu não acho [que deveria ser controlada], e até acho que quando vejo essas coisas na internet é interessante para se ter uma ideia do país em que você vive. Porque há muita 
mentira, muita hipocrisia com relação a racismo, em relação à tolerância de diferenças, aos homossexuais e tudo mais. Ninguém quer dizer que é racista. Há pesquisas nesse sentido. Isso foi feito em São Paulo já faz algum tempo e não me lembro dos números. Pessoas que se declaravam racistas: $1 \%$. Pessoas que conheciam racistas: 99\%! Tem alguma coisa errada aí [risos]. Então, você tem mais ou menos a temperatura do país em que vive, da sociedade em que vive, deixando, abrindo para esse tipo de manifestação. É crime explicitar o racismo, não pode chamar "o negro não sei quê". Mas o cara que faz isso anonimamente na internet, de certa forma, está te dando uma ideia de como a questão é vista no Brasil. O problema do racismo é absurdo. E é mais absurdo ainda sendo o Brasil o que é: uma sociedade miscigenada. O racismo é uma espécie de autorracismo.

Em outro vídeo, você falou: "Desde pequeno eu tinha impressão de que um dia eu ficaria velho. E fiquei”. Sempre teve essa expectativa?

[Risos] Eu desconfiava de que um dia ficaria velho... Porque tem pessoas que não desconfiam. Acham que nunca serão velhos, como acham que nunca foram pretos.

Mas não é um problema para você? No disco tem uma música sobre isso, "Barafunda".

Eu lido muito bem com isso, inclusive porque eu nem acredito que seja velho [gargalhadas]! Nem acredito que vá ficar velho um dia. Então eu dou risada. Outro dia, descobri que fiquei mais velho que o Vinicius de Moraes. Daí eu estava jogando futebol e tinha um garoto de 20 anos, que me deu um carrinho com campo molhado. Me acertou o tornozelo. Fiquei puto: "Moleque de merda!" E daí a pouco fiquei orgulhosíssimo: ninguém daria um carrinho desses no Vinicius. Ninguém [gargalha]! Nem no Tom [Jobim]. O Tom se foi com a minha idade, 67.

Neste mês completam-se 45 anos do II Festival da Música Popular Brasileira, que teve "A Banda" $e$ "Disparada" como vencedoras. Hoje, sabe-se que a sua música ganhou na votação, mas você exigiu o empate. $O$ que aconteceu? [Risos] Acho que metade foi generosidade e metade foi medo. Ganhar aquilo sozinho ia ser difícil, porque ali estava rachado... E, quando digo generosidade, não estou brincando. Eu realmente achava que "Disparada" era uma música superior a "A Banda". Eu gostava muito, tanto que, há pouco tempo, fui a São Paulo para um prêmio literário, o Jair Rodrigues cantou essa música e quase chorei. Eu não sou muito de chorar. É muito bonita.

Essa competição dos festivais chegou a virar algo não saudável? No fim dos anos 60, foi muito noticiado o desentendimento que você teria com o Caetano, quando ele gravou "Carolina".

Isso foi basicamente em 1967, quando surgiu o Tropicalismo. Eu fui eleito pelos teóricos do Tropicalismo, pelos jornalistas, como o adversário a ser abatido. Então realmente foi muito pesado, porque eu estava quase sozinho nessa história. E aquilo contaminou um pouquinho, a gente meio que se afastou, mas não tanto por causa disso. Eu já morava no Rio, e o Gil e o Caetano, em São Paulo. Eles estavam andando em outro círculo. A gente se afastou até por questões geográficas e não houve muito tempo para se entender e conversar. Mas não foi nada pessoal, nenhum ataque pessoal do Caetano a mim e nem vice-versa. Do Gil também não.

Eles diziam que a sua música era conservadora.

$\mathrm{Na}$ época, eu estava aprendendo a fazer música com o Tom Jobim, começando as minhas parcerias com ele. Estava preocupado com outras coisas. E fui eleito como alvo preferencial do Tropicalismo. Isso ficou rendendo muito tempo, esse Fla-Flu. Mas o fato de o Gil, o Caetano e o Milton estarem atuantes até hoje é, para mim, muito bom. 
Eu diria que, de certa forma, uma competitividade é saudável. Primeiro, eles são muito mais velhos do que eu, vão fazer 70 anos no ano que vem... [risos] Se eles estão compondo, gravando e cantando, não vou me acomodar. "Ah, também quero fazer!" Nesse sentido, é bom. Se o Caetano amanhã desistir de fazer música, vou ficar triste. E, ao mesmo tempo, vou dizer: "Ah, que preguiça, vou parar também”. Nesse sentido, pode existir um estímulo que vem da competição, do espírito competitivo. Se bem que o Caetano é mais competitivo do que eu. Outro dia ele viu uma foto minha, ficou com inveja da minha barriga e está criando uma maior do que a minha [risos].

Para encerrar: se eu perguntar quem é a pessoa musicalmente mais importante para você, qual é o primeiro nome que vem à cabeça?

O Tom Jobim. Eu o situaria ao lado do João Gilberto, são os responsáveis pela minha formação. Tom foi um amigo, um parceiro com quem aprendi e de quem fui muito próximo. Vi ele compondo "Águas de Março", ele tinha esse lado meio exibicionista. E o João foi a revelação, o ponto inicial. 